MARCIEL APARECIDO CONSANI

\title{
Mediação Tecnológica na Educação: Conceito e aplicações
}

Tese apresentada ao Programa de Pós-Graduação em "Ciências da Comunicação", Área de "Interfaces Sociais da Comunicação", Linha de Pesquisa "Educomunicação", da Escola de Comunicações e Artes da Universidade de São Paulo (ECA/USP), como exigência parcial para obtenção do Título de Doutor em Ciências da Comunicação, sob a orientação do Prof. Dr. Ismar de Oliveira Soares.

São Paulo

2008 
Marciel Aparecido Consani

Mediação Tecnológica na Educação:

conceito e aplicações

Banca Examinadora

Presidente:

Prof. Dr. Ismar de Oliveira Soares

São Paulo, de

de 2008. 


\section{Resumo}

A tese aborda a área de intervenção educomunicativa "Mediação Tecnológica na Educação” MTE. Trata-se de uma das vertentes nas quais o campo da Educomunicação se estrutura epistemologicamente e que se encontra bastante evidenciada, nos dias de hoje, por conta da educação a distância (EaD).

Nossa proposta é fazer um amplo levantamento do sentido e significado da MTE, de modo a aclarar seu entendimento a partir da análise histórica, etimológica e lingüísticopragmática sobre os usos correntes da expressão nos campos onde ela ocorre. A saber: a educomunicação, a comunicação e a educação.

Espera-se, ao final, obter um nível de compreensão elevado sobre a MTE, permitindo que ela respalde com maior robustez a praxis das ações educomunicativas, principalmente daquelas identificadas com os vários projetos implementados na parceria entre o NCE e o poder público.

Palavras-chave: Educomunicação, Mediação, Comunicação, Educação, Tecnologia. 


\section{Abstract}

This study examines the Educommunication intervention called "Technology Mediation in Education (MTE). This is one of the epistemological areas in which the field of Educommunication is built, clearly found in Distance Learning programs.

Our objective is to conduct a detailed analysis of the meaning and significance of MTE, its history, etymology, and linguistic characteristics, as well as its current use in educommunication, communication, and education.

We anticipate that this level of analysis will bring about a higher level of understanding of MTE, allowing for stronger educommunication praxis, particularly the practices implemented by the partnership between NCE and the public sector.

Key terms: educommunication, mediation, communication, education, technology 


\section{Agradecimentos}

Agradeço primeiramente, o apoio fundamental da minha família para a realização deste trabalho, compartilhando o desgaste e oferecendo ajuda.

Pela ordem: Angela (mulher), Da. Laura (mãe), Sr. Adhemar (pai), Da. Asuncion (sogra) e Sr. Angel (sogro) e Maristela (irmã).

Sou grato — e muito — aos colegas do NCE-ECA/USP pelo apoio indispensável nesta realização, especialmente

Patrícia Horta Alves e Robson Braga, Renato Tavares Jr., além de Valdinete Souza e Richard Romancini, desculpando-me pelas muitas omissões.

Meus agradecimentos às valiosas sugestões dos professores

Adilson Odair Citelli e Sonia Maria Vanzella Castellar

Agradeço, também, às minhas revisoras

Maria Salete Prado Soares e

Dóris Sanches Pinheiro

E é claro (last but not least) ao meu orientador pela confiança, apoio e a ensinança:

Obrigado Professor Ismar Soares. 


\section{Dedicatória}

Dedico este trabalho ao meu filho Matheus Rama Consani

(agora já podemos brincar mais) 


\section{SUMÁRIO}

INTRODUÇÃO: ESCOPO E ÂMBITO DESTA TESE $\quad 01$

$\begin{array}{ll}\text { Apresentação } & 03\end{array}$

$\begin{array}{ll}\text { Relato de uma trajetória interdisciplinar } & 07\end{array}$

$\begin{array}{ll}\text { Eu e as máquinas } & 10\end{array}$

Construindo um Quadro Teórico Referencial em Educomunicação 17

Vigotsky e Freire: uma ponte epistemológica possível e necessária 21

Enfoque metodológico 25

Amostragem e tratamento $\quad 28$

Instâncias da pesquisa $\quad 30$

Estrutura desta tese 33

$\begin{array}{ll}\text { I. FUNDAMENTAÇÃO EDUCOMUNICATIVA } & 37\end{array}$

1.1 Entendendo a Educomunicação: discussões preliminares 39

1.1.1 Compreensão epistemológica da Educomunicação 43

1.1.2 Compreensão histórica da Educomunicação e de suas 47 áreas de intervenção (vertentes)

1.1.3 A vertente educomunicativa da MTE 54

1.2 Breve histórico analítico dos projetos do NCE 58

1.2.1 Educom.TV 60

1.2.2 Educom.rádio São Paulo 62

1.2.3 Educom.rádio Centro-Oeste 65

1.2.4 Educom.Geração Cidadã 67

$\begin{array}{ll}1.2 .5 \text { Outros projetos } & 70\end{array}$

$\begin{array}{ll}\text { 1.2.5.1 Educom.Saúde } & 70\end{array}$

1.2.5.2 Tô de olho.TV 71

1.2.5.3 Educom.CSL (Colégio São Luís) 71

$\begin{array}{ll}\text { 1.2.5.4 Educom.Fundhas } & 72\end{array}$ 
II. MTE: A CONSTRUÇÃO DE UM SENTIDO

2.1 Para que serve fixar um sentido? $\quad 77$

2.1.1 Mediação: uso ou abuso lexical?

2.2 O conceito de mediação e suas transformações históricas 82

2.2.1 A mediação na Filosofia Clássica 82

2.2.2 A mediação em Hegel 84

2.2.3 A mediação na Filosofia Marxista 87

2.3 A teoria das mediações $\quad 89$

2.3.1 As contribuições de Serrano $\quad 89$

2.3.2 As contribuições de Martín-Barbero 94

2.3.3 As contribuições de Orozco Gómez 102

2.4 Etimologia de "Meio" e "Mediação" no Latim 112

2.5 Etimologia de "Meio" e "Mediação" no idioma inglês 116

III. MTE: A CONSTRUÇÃO DE UM SIGNIFICADO 127

$\begin{array}{ll}3.1 \text { Significados construídos, significados a construir } & 129\end{array}$

$\begin{array}{ll}3.1 .1 \text { Esclarecendo sobre Vigotsky } & 131\end{array}$

$\begin{array}{ll}3.2 \text { Modelos visuais para entender a Mediação } & 143\end{array}$

3.2.1 Modelo Gráfico Elementar 144

3.2.2 Modelos Gráficos Culturais 149

3.2.2.1 O modelo matemático de comunicação 149

3.2.2.2 O processo de comunicação humana de Bordenave 151

3.2.2.3 A ZDP e a dupla natureza da mediação 154

3.2.2.4 O modelo de análise das situações midiatizadas 157 de ALAVA

3.2.3 Interpretação sobre os modelos gráficos 162

$\begin{array}{ll}\text { 3.2.4 A Metáfora da Orquestra } & 168\end{array}$ 
IV. MTE: A HISTÓRIA DE UM CONCEITO 175

$\begin{array}{ll}4.1 \text { A história de um conceito } & 177\end{array}$

4.1.1 Um conceito para a Tecnologia 179

4.1.2 Integração das tecnologias na escola 183

4.1.3 Nomes diferentes para uma mesma idéia 187

4.2 O elemento Político-Pedagógico ou "um debate histórico" 194

4.3 Sobre o mediador: o exemplo emblemático do $\mathrm{POIE}^{1} \quad 197$

4.3.1 O Projeto Gênese e os primórdios da MTE na rede pública 198

4.3.2 Visão Público-Institucional e Visão Tecno-Corporativa 201

4.4 O MEC e as políticas públicas da MTE 204

4.4.1 O e-Proinfo 206

4.4.2 O curso Formação Continuada em Mídias na Educação 208

CAPÍTULO FINAL: Considerações Finais $\quad 212$

$\begin{array}{ll}\text { Conclusões } & 214\end{array}$

Possíveis itinerários na leitura deste trabalho $\quad 217$

Contribuições conceituais da pesquisa $\quad 220$

Contribuições metodológicas da pesquisa 223

Problemas e pontos para desenvolvimento futuro, possíveis omissões 225

REFERÊNCIAS $\quad 227$

Bibliografia básica 228

$\begin{array}{ll}\text { Bibliografia específica } & 231\end{array}$

$\begin{array}{ll}\text { Bibliografia complementar } & 238\end{array}$

$\begin{array}{ll}\text { Bibliografia eletrônica } & 242\end{array}$

CRÉDITOS DO AUTOR

$\begin{array}{ll}\text { ANEXOS } & 245\end{array}$

Guia didático do Tutor do Curso Mídias na Educação (e-Prolnfo/MEC) 246

1 Sigla do cargo de Professor Orientador de Informática Educacional. 


\section{ÍNDICE DE QUADROS E GRÁFICOS}

QUADROS

pág.

Quadro 1: enunciado da hipótese principal 26

Quadro 2: enunciado das hipóteses tributárias $\quad 27$

Quadro 3: universo da amostra pesquisada 29

Quadro 4: $\quad$ aspectos divergentes entre processos comunicativos e educativos 42

Quadro 5: aspectos divergentes entre processos comunicativos, 46 educomunicativos e educativos

Quadro 6: síntese dos pontos sistematizados pela pesquisa perfil 50

Quadro 7: síntese das hipóteses declaradas na pesquisa perfil 51

Quadro 8: síntese das áreas de intervenção identificadas na pesquisa perfil 52

Quadro 9: síntese do projeto Educom.TV 61

Quadro 10: síntese do projeto Educom.rádio 65

Quadro 11: condições diferenciadas dos projetos Educom.rádio São Paulo e 66 Centro-Oeste

Quadro 12: síntese do projeto Educom.rádio Centro-Oeste 67

Quadro 13: síntese do projeto Educom.Geração Cidadã 69

Quadro 14: síntese geral dos demais projetos coordenados pelo NCE 74

Quadro 15: síntese dos tipos de mediação em Manuel Martín Serrano 93

Quadro 16: caracterização Analítica das Mediações (LOPES) 107

Quadro 17: MEDIUM - verbete do léxico latino-português 113

Quadro 18: MEDIUM - síntese semântica 114

Quadro 19: MEDIATION - verbete do léxico inglês e tradução 117

Quadro 20: MEDIATE - verbete do léxico inglês e tradução 119

Quadro 21a: MEDIUM - verbete do léxico inglês e tradução 121

Quadro 21b: MEDIUM- verbete do léxico inglês e tradução (continuação) 122

Quadro 22: definição alternativa de mediação 144

Quadro 23: síntese dos elementos da mediação/perguntas contextualizadoras 169

Quadro 24: aplicação da Metáfora da Orquestra $\quad$ 172-4

Quadro 25: abordagens pedagogicamente/tecnologicamente orientadas 187

Quadro 26: a metodologia de LOPES (2003) aplicada à Metáfora da Orquestra 224 


\section{GRÁFICOS}

Gráfico 01: modelo de ZDP de quatro estágios 141

Gráfico 02: combinação organizada de elementos díspares 144

Gráfico 03: incompatibilidade na relação entre dois elementos 145

Gráfico 04: elemento isolado $\quad 145$

Gráfico 05: relações compatíveis de elementos isolados parcialmente díspares 146

Gráfico 06: relação mediada destacando o mediador ativo 146

Gráfico 07: agrupamento sinérgico como resultado da mediação 146

Gráfico 08: modelo matemático de comunicação de SHANNON \& WEAVER 149

Gráfico 09: percepção da realidade segundo BORDENAVE 151

Gráfico 10: interpretação da realidade segundo BORDENAVE 152

Gráfico 11: compartilhamento de significados na comunicação (BORDENAVE) 153

Gráfico 12: relação lógica na mediação de signos e instrumentos (VIGOTSKY) 157

Gráfico 13: dinâmica didática e dispositivo midiatizado (ALAVA) 159

Gráfico 14: mediação e midiatização dos processos de formação (ALAVA) 161 


\section{INTRODUÇÃO}

\section{ESCOPO E ÂMBITO DESTA TESE}




\title{
Apresentação
}

A palavra dos homens é o material mais duradouro. Se um poeta deu corpo à sua sensação passageira com as palavras mais apropriadas, aquela sensação vive através de séculos nessas palavras e é despertada novamente em cada leitor receptivo (SCHOPENHAUER).

\begin{abstract}
O título aqui apresentado - "MEDIAÇÃO TECNOLÓGICA NA EDUCAÇÃO: CONCEITO E APLICAÇÕES" — deixa entrever algumas particularidades:
\end{abstract}

(1) a Mediação Tecnológica na Educação $\left(\mathrm{MTE}^{1}\right)$, que é nosso objeto de estudo, configura-se num conceito e numa abordagem operativa ainda em construção;

(2) não obstante a afirmação anterior, verificamos que se trata de uma expressão corrente (por vezes, com algumas variantes) em contextos acadêmicos e nãoacadêmicos de diversas áreas e campos distintos. No mais das vezes, o uso da expressão ocorre sem a contextualização de um recorte definido e, comumente, sem contextualização alguma;

(3) para um desses campos, o da Educomunicação $^{2}$, a MTE - seu sentido e significado específico - reveste-se de uma importância particularmente grande, já que se trata, no entender do Núcleo de Comunicação e Educação da ECA/USP ${ }^{3}$, de uma de vertentes ou áreas de intervenção constitutivas do novo campo ${ }^{4}$;

1 Devido ao número elevado de ocorrências dessa expressão em nosso texto, preferiremos utilizar, daqui para frente, seu acrônimo.

2 O NCE-ECA/USP entende que as Mediações Tecnológicas nos espaços educativos constituem-se como um das áreas de intervenção da Educomunicação, definida por Ismar de Oliveira SOARES como "o conjunto das ações inerentes ao planejamento, implementação e avaliação de processos e produtos destinados a criar e fortalecer ecossistemas comunicativos em espaços educativos, melhorar o coeficiente comunicativo das ações educativas, desenvolver o espírito crítico dos usuários dos meios massivos, usar adequadamente os recursos da informação nas práticas educativas e ampliar a capacidade de expressão das pessoas" (SOARES, 2005), grifos do autor.

3 O Núcleo de Comunicação e Educação da USP, sediado na Escola de Comunicações e Artes, é um grupo de pesquisa e extensão cultural que desde 1996 dedica-se a investigar o conceito e as práticas educomunicativas. Informações detalhadas podem ser obtidas no site http://www.usp.br/nce.

${ }_{4} \quad$ A discussão sobre o conceito e a apresentação do conjunto das vertentes da Educomunicação será desenvolvida no capítulo I. 
(4) as dimensões teórica (de natureza conceitual) e prática (de natureza programática) do conceito da MTE, além de contribuir para a consolidação do corpus teórico da Educomunicação, têm-se mostrado capazes de estabelecer linhas de aproximação epistemológica com campos afins, primordialmente os da Comunicação, Educação e Tecnologia ${ }^{5}$.

Essas quatro reflexões encadeadas num curto primeiro enunciado, enquanto fornecem indícios de nossa justificativa e dos objetivos a ela atrelados, dão conta de precisar o objeto geral de estudo (seus diferentes conceitos e alguns exemplos de aplicação dos mesmos).

Mesmo estabelecendo uma tal delimitação temática, podemos observar, ao longo de nosso texto, a presença de algumas variações, ainda que sutis, na forma de como a ela nos referimos, na tentativa de obtermos um sentido mais preciso e coerente.

Por exemplo, quando nos propomos a falar sobre Mediação Tecnológica $\boldsymbol{n a}$ (ou $\boldsymbol{e m}$ ) Educação, estaríamos orientando a nossa análise de dentro para fora, referindo-nos a algo que acontece fora da educação e a ela se aplica (MT com ou sobre a Educação) ou, pelo contrário, trataríamos de algo que acontece no interior do campo educativo e, portanto, é de dentro desse campo que extrairemos os parâmetros para analisar as interfaces pedagógicas com a Comunicação e a Tecnologia? Ainda que não possamos garantir, ao final, uma posição "definitiva" (no sentido etimológico de "dar fim" à questão), consideramos tais colocações necessárias no estágio ainda nebuloso que envolve os processos analisados.

Sem responder, neste momento, às questões colocadas há dois parágrafos, consideramos cabível afirmar que "certezas provisórias" emergirão de nossas investigações em torno da MTE tal como ela é interpretada a partir do que consideramos ser a visão educomunicativa. Tema e abordagem são, na verdade, elementos de nossa pesquisa que se complementam com a exposição mais detalhada de suas justificativas, as quais serão reiteradas e realinhadas ao longo de todo o trabalho ${ }^{6}$.

5 Embora ainda prevaleça em diversos setores a noção tecnicista-simplista da Tecnologia como "Aplicação do conhecimento científico aos processos industriais" (COLLINS, 2001: 407), adotamos aqui uma concepção muito mais ampla, cuja discussão terá lugar no capítulo II.

6 A abordagem educomunicativa será desenvolvida logo no início do capítulo I desta tese. 
Como justificativa principal, observamos há pouco, dentro do primeiro enunciado, que a necessidade de significação/re-significação do termo MTE não só existe como atende à necessidades que não se limitam ao quadro teórico da Educomunicação. Cabe ainda ressaltar que a presença de dubiedades, imprecisões e inconsistências no uso da expressão agravam o risco de esvaziá-la enquanto conceito, inviabilizando também seu emprego como categoria de análise

A par desta justificativa mais premente, poderíamos agregar, na forma de um segundo enunciado, os objetivos específicos envolvidos neste projeto de pesquisa:

I. ajudar a entender como se processa a relação entre Mediação e Mídia;

II. desenvolver instrumentos de pesquisa adequados aos parâmetros diferenciais vislumbrados no referencial educomunicativo;

III. fornecer subsídios práticos para referenciar a atuação de mediadores em projetos educomunicativos.

Contextualizando esse último objetivo, podemos invocar a experiência acumulada pelo NCE/USP em decorrência de diversas parcerias tanto e principalmente no âmbito das políticas públicas, quanto no espaço da iniciativa privada, junto ao primeiro e terceiro setores $^{7}$.

Sempre em busca de uma melhor compreensão, podemos expor de forma diferente o conjunto de nossos objetivos, ou como um terceiro enunciado, na forma de uma lista de tarefas a serem realizadas concomitantemente:

(1) aclarar o conceito da MTE em si, ampliando e fortalecendo o quadro teórico que dá suporte à Educomunicação;

7 A relação dos projetos desenvolvidos pelo NCE/USP, ao longo dos últimos dez anos, pode igualmente ser encontrada no site da instituição. 
(2) definir, tanto quanto possível, um sentido preciso que legitime o uso da expressão, sem o risco iminente de esvaziar-lhe o sentido e diluir a importância das discussões que ela naturalmente suscita.

(3) contribuir para a definição de um sentido preciso do verbo "mediar" no que tange ao emprego da Tecnologia num ecossistema comunicativo/educativo. Esta demanda é atual: a expressão "mediador" foi trabalhada nas dissertações de mestrado de Renato Tavares Junior ${ }^{8}$ e, mais especificamente, de Claudia Vicenzo $^{9}$, ao estudarem a qualificação profissional e o perfil dos especialistas que implementaram o projeto Educom.rádio junto a 455 escolas do município de São Paulo, entre 2001 e 2004, necessitando, no momento, ser mais bem aprofundada em seu sentido epistemológico, quanto aplicada para definir as relações que se estabelecem nos projetos educomunicativos, em seu conjunto, envolvendo ou não a Educação a Distância (EaD);

(4) alinhar as diferentes abordagens tecnológico-educativas evidenciando as relações históricas e epistemológicas entre elas. Mais uma vez, interessa-nos estabelecer o vínculo conceitual para favorecer a pesquisa na área e o vínculo procedimental para incrementar o planejamento e a avaliação de projetos educomunicativos;

(5) compreender o processo histórico que originou as correntes contemporâneas de estudo e emprego da relação tecnologia-educação-comunicação. Sabedores de que, no bojo de todo processo histórico, existe um movimento socioeconômico, propomo-nos evidenciar este último, situando politicamente a pesquisa dentro de um esforço para transformação qualitativa da sociedade ${ }^{10}$.

8 O trabalho tem como título "Educomunicação e expressão comunicativa: a produção radiofônica de crianças e jovens no projeto Educom.rádio" e foi defendida no Programa de Pós-Graduação da ECA/USP, em 2007.

9 O título da pesquisa de Claudia VICENZO, defendida no mesmo programa, em 2007, é: “A prática da mediação em processos educomunicativos: o caso do Projeto Educom.Rádio".

10 "É por isso também que não me parece possível nem aceitável a posição ingênua ou, pior, astutamente neutra de quem estuda, seja o físico, o biólogo, o sociólogo, o matemático ou o pensador da 
As tarefas enumeradas como "3", "4" e "5" se relacionam às anteriores de uma perspectiva complementar, ainda que não meramente instrumental. De certa forma, elas nos fornecem um balizamento para o recorte temático no qual concentramos nossa investigação: a formação de educadores, tomando como estudo de caso a experiência acumulada deste pesquisador junto ao curso "Formação Continuada em Mídias na Educação" (2005-2008), realizado pela parceria MEC/NCE-USP/SEE-SP na modalidade EaD, como veremos no capítulo IV.

Para reforçarmos a propriedade e pertinência do recorte, ajudando a construir e robustecer as linhas de raciocínio aqui desenvolvidas, parece-nos necessário apresentar nossos referenciais de formação. A intenção desse parêntese um tanto longo é, tão somente, evitar uma pretensa postura de neutralidade e objetividade, já que nossa orientação metodológica busca, ao invés, explicitar a origem de nossas próprias concepções e juízos. ${ }^{11}$

\section{Relato de uma trajetória transdisciplinar}

Ao longo do presente texto, despontará, inevitavelmente, o ponto de vista de um educador em transição constante, o que deve soar quase como um pleonasmo, na medida em que, nos dias de hoje, o conceito de formação permanente é dominante (ao menos, no plano do discurso) em todas as áreas, com destaque para a educacional.

Enquanto experiência profissional posso dizer que educar (ou "ensinar", ou "dar aulas", denominações correntes quando iniciei minha trajetória, nos idos de 1985) sempre foi uma atividade que captou melhor meu interesse e aptidões do que minha própria escolha original: a carreira de músico.

Por conseqüência, mesmo antes de deixar a faculdade, já atuava como professor de música, primeiro em casa e, logo, em conservatórios e pequenas escolas. Finda a graduação, creio que o divisor de águas dessa etapa foi a opção por me dedicar totalmente à

educação. Ninguém pode estar no mundo, com o mundo e com os outros de forma neutra.” (FREIRE, 2002, 86).

11 "O pesquisador é um homem ou uma mulher com um a inserção social determinada e com uma experiência de vida e de trabalho que condicionam sua visão do mundo, modelam o ponto de vista a partir do qual ele ou ela interagem com a realidade. E é esta visão do mundo, este ponto de vista que vai determinar a intencionalidade de seus atos, a natureza e a finalidade de sua pesquisa, a escolha dos instrumentos metodológicos a serem utilizados." (BRANDÃO, 1999: 24). 
Música, dividindo meu tempo como instrumentista, "Instrutor de Música"12 e "produtor musical independente" numa aventura empresarial de dois anos, devidamente documentada nos anais da Zeugma Assessoria em Comunicação S/C Ltda. O final dessa primeira fase turbulenta seria um período de relativa estabilidade no exercício do papel de professor de música em algumas escolas de educação infantil e ensino fundamental ou, como se chamava antes, "Primeiro Grau".

Nessa primeira fase de minha carreira, eu defendia as convicções que cabem a um "bom instrutor", tais como:

(a) crença numa linha específica de formação - no caso, ligada à musicalização infantil — orientada para a apreciação do modelo a clássico ou erudito (da música) como o ideal ${ }^{13}$;

(b) importância emprestada aos materiais - no caso, exemplos sonoros e sugestões de atividades — como centro da atividade pedagógica;

(c) integração com o projeto pedagógico da instituição pensada a partir da própria especificidade;

(d) caráter eminentemente prático, oficinal, dos objetivos da área específica voltada mais para a prática/performance do que para a compreensão global da Arte.

Entretanto, a necessidade, seja ela de natureza intrínseca ou extrínseca, parece ser o fator determinante de nossas escolhas ao longo da vida. É o que explica o fato de, poucos anos depois, vir a assumir o cargo de "Arte-Educador" nos quadros de uma instituição estatal - a Secretaria Estadual do Menor - que se propunha a trabalhar num modelo

\footnotetext{
12 Na verdade, a função que eu exercia no Centro de Desenvolvimento Infantil "Tetela Papa" (creche do SESC/SENAI) não é - como não era, na época — reconhecida pelo sindicato dos professores (e muito menos pelo sindicato dos músicos), o que me colocava num certo "limbo" profissional.

13 Na época, mesmo que não soubesse, adotava o ponto de vista expresso por T. W. Adorno em obras como Filosofia da Nova Música (ADORNO, 2007a) e Indústria Cultural e Sociedade (ADORNO, 2007b).
} 
educacional alternativo, regido com base na (então) recém-lançada Lei $N^{\circ} 8.069$, de 13 de julho de 1990, mais conhecida como "Estatuto da Criança e do Adolescente" (ECA).

Após uma ou duas semanas de um certo "choque de realidade", sobrou um saldo de muitas certezas demolidas, inclusive a maior parte de minhas convicções relativas a uma educação disciplinadora e "metodocêntrica".Poderia apresentar uma longa série de diferenças contrastantes em relação ao meio escolar dentro do qual eu atuara até então e a “nova experiência”, mas, para ficar só nas principais, menciono:

(1) a falta de um programa de conteúdos predeterminados antecedendo o trabalho educativo, o qual só seria estabelecido após um planejamento conjunto com outros educadores amparado no diagnóstico preliminar das necessidades detectadas;

(2) o caráter integrado deste planejamento, alinhavado por macro-objetivos pedagógicos, não circunscritos a um "currículo" fixo e hierarquizado de conhecimentos dentro de um estatuto disciplinar;

(3) a possibilidade de escolha (dentro de um leque de opções) oferecida às crianças e jovens (que não deveriam ser chamados de "alunos") para uma participação sempre eletiva e minimamente normatizada;

(4) a ênfase nas vivências lúdicas como modelo de atividade pedagógica, em lugar do modelo tradicional da aula expositiva e padronizada;

(5) a necessidade de se utilizar o materiais didáticos disponíveis para o planejamento das atividades, ou recorrer ao improviso criativo para suprir a carência de determinados itens ${ }^{14}$;

(6) a falta, em princípio, de uma estrutura de poder repressivo (inspetoria, "salinha do diretor”) para resolver objetivamente os problemas classificáveis como

\footnotetext{
14 No meu caso, invariavelmente, faltavam instrumentos musicais, o que acarretava sempre a
} manufatura de sucedâneos a partir da sucata de material reciclável. 
“comportamento indesejável”, fato que obrigava a adoção de estratégias de negociação para com as crianças mais voluntariosas;

(7) a afirmação constante e convicta (mas não necessariamente entendida e praticada) de que "o que importa na prática pedagógica é o processo, não o produto";

(8) o fechamento e avaliação sempre coletivizada das atividades, com todos os participantes dispostos em círculo e manifestando sua opinião.

Embora, naquele princípio da década de 1990, o nível de sistematização dessas práticas - ainda que imperfeitas e incipientes, inegavelmente inovadoras para a época (mais ainda por tratar-se de uma iniciativa estatal) — fosse muito aquém do desejável, um novo olhar sobre os fins e meios da praxis educativa já me havia distanciado da concepção escolar sob a qual eu próprio havia sido educado.

Sem a consciência efetiva do fato, eu já exercia a dinâmica da mediação, e os anos subseqüentes me convenceram de que "Testemunhando objetivamente sua história, mesmo a consciência ingênua acaba por despertar criticamente, para despertar como personagem que se ignorava e é obrigada assumir seu papel.” (FREIRE, 1987:15).

Faltava-me ainda um posicionamento pessoal ante o papel crescente da tecnologia digital, o qual compõe a segunda parte do meu relato.

\section{Eu e as máquinas}

Retrocedendo um pouco em meu histórico pessoal, recordo-me do período no qual freqüentei regularmente a escola pública (1979-1982) e que corresponde à duração total do então "Ginásio", equivalente que hoje chamamos de "Ensino Fundamental Nível II". Naquela época, poucos dentre os meus professores haviam visto um computador de perto e, possivelmente, nenhum deles imaginaria que aquela máquina estranha e complicada um dia faria parte da rotina das escolas públicas. 
Em 1984, graças ao primeiro contrato de emprego ${ }^{15}$, vivenciei, pela primeira vez, a operação de um computador — um letárgico XT, cheio de rituais e enigmas: qualquer deslize resultava em pane, paralisação do sistema e numa repreensão da matriz por "uso indevido". Na ocasião, a impressão que tive daquele aparelho era a de que se tratava de um equipamento cujo uso permaneceria irremediavelmente restrito a um punhado de engenheiros e especialistas.

Não obstante, o respeito que aquele "totem eletrônico" impunha até aos meus superiores mais graduados já despertava uma noção difusa de que, na "microfísica do poder corporativo", tal aparato exerceria ainda grande influência.

Seriam necessários ainda alguns anos para que, estimulado por amigos algo deslumbrados, eu viesse a conhecer o poder da interface gráfica, a ponto de considerar a possibilidade de, algum dia, comprar uma daquelas máquinas impressionantes e caras.

A essa altura, eu já havia me decidido profissionalmente pela música e o que despertou meu interesse pela tecnologia digital foram as possibilidades quase ilimitadas oferecidas por esse novo "instrumento musical". Sobre essa escolha, pesou bastante a influência de um certo professor da graduação que dominava alguns dos primeiros programas $\mathrm{MIDI}^{16}$ lançados no mercado brasileiro, e que facilitavam a produção e o aprendizado de arranjos musicais.

Já naquela época, um contraponto para tanta e tão bem-vinda inovação foi representado pela visita, à faculdade de música, de um grupo de técnicos-músicos que atuavam como escola de música eletrônica e na revenda de sistemas musicais computadorizados. Após ilustrar as maravilhas da computação musical submetendo alguns instrumentistas a competições desiguais em velocidade de execução contra as máquinas, um dos demonstradores viu-se constrangido diante da própria incapacidade de realizar uma tarefa simples, que consistia em tocar o baixo de um conhecido minueto de J. S. Bach. Pode-se dizer que, na ocasião, uma onda de criticismo tecnológico me envolveu e a quase todos os músicos que presenciaram a cena.

\footnotetext{
15 Sintomaticamente, tratava-se do departamento de cobrança de um cartão de crédito multinacional, parece que computadores, dinheiro e dívidas são parceiros de longa data.

16 Musical Instruments Digital Interface é um protocolo de comunicação desenvolvido no início dos anos 1980, que permite a troca de informações entre processadores eletrônicos com a finalidade específica de produção de sons musicais. Além de ser um formato de arquivo comum na Internet, o MIDI permite, por exemplo, a comunicação entre um computador doméstico e um teclado eletrônico popular.
} 
Efetivamente, eu só viria a adquirir um computador pessoal em meados de 1995, optando por conectar-me, dois anos depois, à Internet (que ainda parecia ser uma solução à procura de problemas para serem resolvidos).

Mais ou menos por aquela época, encaminhei meu currículo como professor de música para uma escola "de grande porte" com instalações de "última geração", situada num "bairro nobre" da capital paulista - se não me engano, era o que constava no anúncio de jornal. O coordenador pedagógico convidou-me a conhecer o espaço e os recursos disponíveis.

Àquela altura, além de ser um “educador convicto", eu nutria grande interesse pela tecnologia digital, impressionado pela forma como este conjunto de invenções revolucionou o fazer e o aprender em minha área de formação acadêmica original (Artes/Música). Não obstante, ainda engatinhava na tarefa de conciliar minha bagagem pedagógica, escolada pelos métodos "tradicionais", com a "nova realidade" que as autoproclamadas "escolas do século XXI" começavam a alardear. Acreditei que, em minha visita, presenciaria o estado-de-arte do que ainda se chamava, à época, de "Tecnologia Educacional".

Logo na entrada, chamou-me a atenção a catraca eletrônica para controle de freqüência baseada num prosaico código de barras impresso nas carteirinhas dos estudantes. Imaginei que, além do alívio docente causado pela extinção do ritual da chamada em aula, a possibilidade de erro ou fraude no controle de presenças tenderia a zero. Intrigou-me um pouco a atuação de um atento inspetor de alunos que acompanhava o acesso dos discentes, como a verificar se as carteirinhas eletrônicas correspondiam aos respectivos portadores.

O que justificaria tanta precaução?

O foco de meu interesse mudou quando fui apresentado à "sala de aula do futuro", a qual contava com uma workstation embutida em cada carteira e uma lousa digital interativa que possibilitava que o professor escrevesse diretamente no desktop dos alunos.

"Veja bem" - disse-me o coordenador — "assim podemos eliminar os cadernos e lápis, pois os alunos levam para casa uma cópia exata da lição, tal qual o professor escreveu na lousa". Ele prosseguiu, apontado para uma pilha de CDs: 
“... Também não usamos mais livros ou apostilas impressas: tudo é digital, e há um CD para cada disciplina e série, contendo toda a matéria e mais uma infinidade de exercícios e questões que o professor pode aplicar".

Antes que eu o inquirisse sobre o porquê das carteiras do século XXI manterem rigorosamente a disposição de filas alinhadas na direção da lousa, ou ainda, se haveria a possibilidade do professor recorrer a outros materiais didáticos (mesmo não "necessitando"), nossa pequena excursão terminou no auditório com equipamento simulador de realidade virtual em 3D.

Sorrindo ante minha pergunta previsível “- Para que isto é usado?”, meu anfitrião explicou, orgulhosamente, que aquele material caríssimo era destinado apenas às aulas de ciências, nas quais os alunos poderiam imergir na simulação virtual e ver "de perto", tridimensionalmente, as reações físicas, químicas e fisiológicas.

E, mais importante que tudo, nas palavras do coordenador " - Os capacetes isolam os alunos uns dos outros, assim, não há conversa, então, não há bagunça!”.

Senti que aquele era o clímax da visita, mesmo porque o coordenador se despediu rapidamente para resolver algum problema relativo ao inspetor nas catracas eletrônicas. Um tanto estarrecido com o que presenciara, e sem os referenciais da cultura tecnológica (que eu apenas começava a construir em minha mente), tentei imaginar o que representaria ser um "aluno do século XXI", sob essa concepção. Achei difícil - e, mais ainda, como educador - assumir o papel que seria esperado do professor, naquele contexto.

De qualquer forma, a motivação para me especializar nas interfaces entre a Educação e a Tecnologia encontrou ali um divisor de águas e os capítulos III e IV desta tese, que apresentam os principais projetos de MTE de que participei, representam, a certo modo, meu acesso a novos patamares da reflexão epistemológica.

Com base nesse reporte informal de meu contato com as TICs ${ }^{17}$, pode-se constatar que, por um ou outro motivo, não me considero um entusiasta de primeira hora dos meios eletrônicos. Na verdade, ao longo do tempo, penso haver adquirido duas certezas relativas que sintetizam minha visão sobre o papel da tecnologia:

17 Acrônimo de Tecnologias da Informação e da Comunicação, termo corrente para designar o conjunto dos meios eletrônicos analógicos e digitais (com destaque para o computador) e que se tornou hegemônico durante a década de 1990 após suceder a designação anacrônica "meios audiovisuais". Muitos educadores ainda adotam esta designação, não obstante sua inadequação, na atualidade. 
(1) no âmbito pessoal (e, não raro, no público também), o volume de recursos, tais como tempo, dinheiro e esforço, empregados para a incorporação da tecnologia nas tarefas produtivas diárias, muitas vezes, não se justifica dentro de uma lógica objetiva de curto e médio prazos. Antes de tudo, essa valorização das novas tecnologias parece atender muito mais a uma pressão social cuja origem remete ao conceito socioeconômico de informacionalismo, tal como é colocado por Castells:

“(...) o informacionalismo é tratado aqui como um mecanismo de desenvolvimento em que a principal fonte de produtividade é entendida como a capacidade qualitativa de otimizar a combinação e o emprego dos fatores de produção com base na informação e no conhecimento" (CASTELLS, 2002: 27);

(2) esse movimento em direção à tecnologia, cada dia mais central em nossas preocupações (como indivíduos e também como sociedade), parece criar uma espécie de "dependência cultural-tecnológica" na maioria dos setores de trabalho. No âmbito acadêmico, a própria noção do que se chama hoje de "P\&D" — e que, em muitos centros autoproclamados "de excelência acadêmica", confunde-se com a ciência propriamente dita - não questiona mais a pertinência das inovações, mas tão somente o ritmo em que elas completarão seu ciclo de vida útil.

Essa segunda certeza relativa, ou conclusão parcial, remete aos escritos de Victor Ferkiss $^{19}$, que há pouco menos de quarenta anos — num mundo sem Internet, portanto vaticinava que:

\footnotetext{
"Num certo sentido, o argumento de que as coisas estão mudando é obviamente verdadeiro: a tecnologia está fadada a afetar outros aspectos da sociedade. Mas isso é completamente diferente de dizer que a tecnologia está fornecendo a base de uma sociedade totalmente nova, ou que passará a ser o elemento de unificação no seio da nova civilização. Os efeitos das mudanças tecnológicas podem, em lugar disso, ser o deslocamento, a distinção entre as idéias e a realidade, a confusão e uma sociedade desarticulada e desunida" (FERKISS, 1976: 88).
}

18 Sigla para "Pesquisa e Desenvolvimento", expressão de uso corrente tanto no meio corporativo quanto nas instituições acadêmicas de capital privado.

19 Refiro-me ao livro "O Homem Tecnológico - Mito e Realidade", hoje, um clássico da futurologia. Social. 
A esta altura, acredito que os pontos relevantes desenvolvidos nesta introdução, merecem nova recapitulação:

(a) o sentido de apresentarmos, aqui, nossas impressões pessoais é o de que elas não sejam tão "pessoais" assim, ou melhor: o reconhecimento de que fazemos parte de uma dinâmica de mudanças sociais que se estende a todos os aspectos de nossa vida, representa o fio condutor de nosso interesse acadêmico;

(b) o recorte enfocado aqui se define como a relação dentro da qual viemos interagindo desde o momento em que optamos pela área de pesquisa: a relação educativa mediada pela cultura possibilitada pelo aparato tecnológico;

(c) o elemento epistemológico, o qual pretendemos desenvolver, é tributário de uma corrente - ou campo emergente - ao qual, como vimos, o Núcleo de Comunicação e Educação da ECA/USP denomina como Educomunicação. A escolha desse referencial teórico particular vem ao encontro de nosso interesse acadêmico, na medida em que, nos pressupostos educomunicativos, identificamos uma interface (ainda que em construção) capaz de responder aos questionamentos que surgiram no decorrer de nossa trajetória de estudo/trabalho e

(d) a ênfase particular na vertente da "MTE" da tese aqui projetada é opção devida, ao mesmo tempo, ao nosso engajamento recente e atual nesta atividade (fator idiossincrásico do pesquisador) e pela detecção de que urge consolidar o conceito dentro da linha de pesquisa da Educomunicação (necessidade institucional).

Ainda no escopo da tese, é nossa pretensão desenvolver mais acuradamente o que se quer traduzir por “dependência cultural-tecnológica”. Há alguns autores (notadamente, no Brasil, o Professor Doutor Valdemar W. SETZER ${ }^{20}$ do IME/USP) que suportam essa linha de raciocínio, embora haja, a meu ver, a necessidade de contextualizá-la dentro de uma ótica mais permeável e generalizável.

20 Referimo-nos à obra Meios eletrônicos e educação: uma visão alternativa, de 2001. 
Chegamos a um ponto de nosso desenvolvimento que torna essencial eleger os principais referenciais teóricos — ou seja, nosso Quadro Teórico de Referência, ou "QTR" (SEVERINO, 2007: 131) a partir dos quais emprestaremos sentido e significado à nossa exposição.

Também é mister reforçar nosso alinhamento com os autores e conceitos que orbitam à volta do campo emergente da Educomunicação. Nesse sentido, pensamos estar contribuindo para uma maior dialogicidade do campo com suas áreas de intervenção, os ecossistemas educomunicativos e, particularmente, com a escola pública.

Um exemplo significativo aqui presente é a proposição de uma linha de continuidade epistemológica a partir das idéias de L. S. Vigotsky ${ }^{21}$ e que se complementa com a pedagogia engajada de Paulo Freire, o qual, por sua vez, é reputada por Soares, como um dos grandes baluartes da matriz educomunicativa.

Assim, além de contar com as idéias dos pesquisadores que efetivamente já estão incorporados no universo da Educomunicação (mesmo que alguns deles se mostrem ainda inseguros no emprego dessa denominação em particular), pretendemos aqui acrescentar novas luzes à investigação que envolve as interfaces entre Comunicação e Educação, inserindo questões e visões a respeito da Mediação que são debatidas no contexto da educação formal.

A maior parte das informações apresentadas neste trabalho se origina de nossa já mencionada vivência nos processos de formação docente (aqui analisados como formação de mediadores), antes e depois de nos integrarmos ao quadro de colaboradores do NCEECA/USP.

$21 \quad$ Esta forma de grafar o nome do educador bielo-russo será a preferencial adotada no texto. Como é comum a variação de grafia em cada uma das fontes por nós consultadas, ocorerão formas alternativas, principalmente dentro de citações. 


\section{Construindo um Quadro Teórico Referencial em Educomunicação}

A definição abrangente de Educomunicação produzida a partir das pesquisas do NCE/USP (SOARES, 1999a) ${ }^{22}$ nos insere no âmago de uma problemática que discute as relações entre a educação e as linguagens e processos da comunicação, no contexto da prática social. Em uma única instância, podemos encontrar a resposta de vários questionamentos, como:

o que ela é: a Educomunicação se caracteriza por sua ênfase prática, tendo o conceito sido formulado a partir da observação do agir de grupos da sociedade civil, ao longo da segunda metade do século XX, que passaram a rever suas práticas educativas à luz da realidade representada pela presença das tecnologias da informação e da comunicação, facilitando o desenvolvimento de projetos político-pedagógicos que objetivavam essencialmente promover a plena democracia nas relações interpessoais, possibilitada pelo modo como os grupos passavam a conceber a gestão dos processos comunicativos. Nesse sentido, a Educomunicação representa, hoje, um processo de renovação dos modos como se dá, na prática social, a inter-relação Comunicação/Educação.

(b) onde ela acontece: a Educomunicação acontece no âmbito dos processos comunicativos carregados de intencionalidade educativa, sempre que pensados e implementados a partir de uma perspectiva de gestão participativa de seus processos, quer seja na prática da educação não formal (comunicação integrada à educação popular de matriz freireana); quer na educação informal (programação educativa implementada através da mídia: rádio, jornal, tv, sites na Internet); ou, ainda, no espaço da educação formal (comunicação educativa no espaço escolar, como metodologia de gestão ou de produção) o que, de certa forma, nos induz

\footnotetext{
22 As conclusões da pesquisa fundante do conceito da Educomunicação, que será objeto de uma breve
} explanação no início do capítulo I, podem ser acessadas em http://www.usp.br/nce/wcp/arq/textos/29.pdf . 
a reconhecer que, no fundo, ambas as abordagens - a educativa e a comunicativa — podem se tornar indissociáveis quando abandonamos a ortodoxia conceitual presente em um e outro campo;

(c) quem a pratica: quando empregamos a analogia do conceito "ecossistema comunicativo" torna-se forçoso pensar numa comunidade de pessoas (agentes do processo educomunicativo) que interagem entre si, enquanto usuários de determinadas tecnologias ou gestores de determinados modos de fazer a comunicação ("mediação"); e

(d) para que ela serve: para ampliar a capacidade de expressão dos indivíduos (ganho individual), melhorando o coeficiente comunicativo das ações educativas, fortalecendo, assim, o ecossistema comunicativo (ganho comunitário), fatos que - em seu conjunto - se constituem em objetivos que, de certa forma, se contrapõem ideologicamente à perspectiva iluminista presente em slogans como "multiplicar o saber", "preservar a cultura", "difundir o conhecimento", comumente associados ao discurso sobre as tecnologias educativas.

É óbvio que, isoladamente, cada um dos conceitos que subjazem a esse arcabouço teórico ainda necessita ser fortalecido por pesquisas que corroborem sua consistência e legitimidade (muitas delas, já em curso no NCE e em outros núcleos de estudo). Isso não impede, porém, que tomadas como um referencial para nossa hipótese de trabalho ajudemnos a respaldar a concretude de nosso objeto de estudo.

Por conseguinte, além de reconhecermos o campo da Educomunicação como autônomo, assumimos a hipótese de que a Mediação Tecnológica na Educação é uma de suas vertentes mais representativas, o que responde à série de questões apresentadas na página anterior, justificando-se a premência de sua investigação.

Enunciada dessa forma nossa hipótese principal (ainda que em versão preliminar), contamos já com elementos suficientes para proceder à delimitação de nosso QTR. A apresentação deste será realizada pela exposição da trajetória da pesquisa ou, mais 
especificamente, no percurso seguido por nossas linhas de raciocínio ao longo dos capítulos que compõem o texto da tese.

Assim:

(1) afirmação dos pressupostos teóricos da Educomunicação: que consiste na apresentação e esclarecimento da terminologia e dos conceitos basilares mais correntes e significativos do campo. Para embasar esta tarefa, concentrada nesta introdução e nos dois primeiros capítulos, recorremos, prioritariamente, aos seguintes autores: ALVES, FREIRE, JACQUINOT, SOARES, e TAVARES JR. ${ }^{23}$;

(2) necessidade de aclarar as imprecisões conceituais ligadas à MTE: o que equivale a precisar os conceitos de "Mediação" e "Tecnologia", além de tipificar as interfaces investigadas em relação ao que definimos aqui por MTE. Nessa demanda, nos apoiaremos em conceitos de ALAVA, BLANCK, BORDENAVE, COLE, MARTÍN-BARBERO, PIAGET, SOARES, GALLIMORE \& THARP e VIGOTSKY;

(3) mapeamento da origem histórica e geográfica da expressão MTE: recorrendo aos indícios epistemológicos apresentados pelos vários autores, esta tarefa consiste em estabelecer a possível trajetória das expressões paralelas e convergentes da MTE. Constarão como suporte os autores: AZEVEDO, GRINSPUN, MORAES, PALLOFF \& PRAT, SAMPAIO e SANCHO;

(4) mídia e mediação: resgate da uma ponte conceitual entre Linguagem e Mídia, sob a perspectiva da Mediação Tecnológica e de seus reflexos na relação educomunicativa. Referências: BARBA, LOPES, MARTÍN-BARBERO, OROZCO GÓMEZ, SANTOS, SERRANO e SIGNATES;

23 Estes e outros autores referidos unicamente pelo sobrenome poderão ser conferidos consultando-se a bibliografia apresentada no final deste texto. 
(5) análise de experiência relatada sobre o papel da MTE: descrição e crítica objetiva de projeto realizado no âmbito das políticas públicas, à luz dos parâmetros até aqui construídos sobre a MTE. Referências: ALMEIDA, AFONSO, AGUIAR, BELLONI, CONSANI, GANDIN, JIMENEZ, LITWIN, PONZO DE MENEZES, SANTOS e SARTORI;

(6) aprofundamentos e reflexões e sobre a MTE: reconstrução do objeto de estudo (LOPES, 2003: 117) a partir do subsídio dos dados analisados anteriormente: ARAÚJO, FERKISS, CROCHIK, PAPPERT, RANGEL, SETZER e VALENTE; e

(7) possíveis contribuições desta pesquisa: apresentação das conclusões "provisórias" da pesquisa e, possivelmente, proposição de novas questões e abordagens. Referências: D’AMBROSIO, FREIRE, SOARES e SAVIANI.

Além dos autores referenciados, um número grande de referências tributárias será utilizado, incluindo publicações institucionais, manuais de referência e textos avulsos acessados em formato impresso ou eletrônico. Destacaremos aqui a relação epistemológica entre as obras de Vigotsky e Freire, devido à significação inferencial que lhe emprestamos em nossa argumentação. 


\section{Vigotsky e Freire: uma ponte epistemológica possível e necessária}

A construção e o desenvolvimento da linha argumentativa aqui exposta apóiam-se na análise de correntes do pensamento pedagógico que, a nosso ver, embasam o que chamamos atualmente de práticas "educomunicativas".

Embora outros pesquisadores também tenham se preocupado em esboçar uma "genealogia" da Educomunicação, entendemos essa tarefa como necessária e ainda pendente, na medida em que a descoberta de novos enfoques associada à releitura de teorias insuficientemente compreendidas acrescentará, naturalmente, novos posicionamentos - não necessariamente conflitantes - aos debates epistemológicos dentro da Educomunicação.

Assim, sem desconsiderarmos o trabalho de Jorge Huergo (apud SOARES, 1999a) que aponta para uma linha de influências sucessivas alinhavando Skinner ${ }^{24}$ e Freinet $^{25}$ a Paulo Freire, estabelecemos aqui como hipótese de trabalho uma ponte epistemológica que liga as idéias de L.S.Vigotsky ${ }^{26}$ às de Paulo Freire $^{27}$ e permeiam, pela nossa visão, o discurso educomunicativo.

Também não intentamos aqui limitar o resgate de outros "elos perdidos" na genealogia do campo. Na verdade, além daqueles aos quais nos referimos, poderíamos elencar uma constelação de estudiosos, os quais, atuando em espaços educativos, defenderam, em maior ou menor alcance, estratégias baseadas na expressão comunicativa ou em alguma linguagem comunicacional específica como, por exemplo, Freinet (com o jornal escolar) ou Roquete Pinto (com seu projeto de rádio educativo), entre tantos outros.

Cabe destacar que a redescoberta da obra do pensador bielo-russo afetou profundamente as convicções pedagógicas da linha construtivista, as quais, por sua vez,

24 Burrhus F. Skinner (1904-1990), psicólogo estadunidense propositor do comportamentalismo ou Behaviorismo.

25 Celestin Freinet (1896-1966), pedagogo francês, incentivador do movimento da Escola Moderna em seu país.

26 Lev Semyonovitch Vigotsky (1897-1934) lingüista e psicólogo bielo-russo autor de "Pensamento e Linguagem".

27 Paulo Regulus Freire (1927-1991), Pernambucano reputado como o mais importante educador brasileiro, escreveu "Pedagogia do Oprimido" e foi secretário municipal da educação em São Paulo entre 1989 e 1991. 
serviram inclusive como base para o estabelecimento de metodologias de MTE nos contextos escolares nas últimas duas décadas ${ }^{28}$. Segundo assinala DAVIS

\begin{abstract}
"Mais recentemente, desde o início da década de 80, no auge da adoção do construtivismo piagetiano pelos professores, um crescente interesse em relação aos autores soviéticos, em especial Vigotsky, surgiu no âmbito universitário. Buscavase neles um efetivo contraponto à proposta de Piaget, sobretudo porque, na maioria dos casos, uma compreensão errônea do construtivismo acabou por desarticular o modo de atuar dos pesquisadores, sem colocar, em seu lugar, um ensino inovador conforme se esperava" (DAVIS, 2005: 38).
\end{abstract}

Foi por exemplo, graças à influência do pensamento de Vigotsky que a aplicação prática da Internet numa perspectiva de trabalho baseada em "redes de conhecimento", desenvolvida em muitas escolas do país, acabou por acrescentar à MTE uma dimensão social desconhecida. Antes disso, durante os anos, predominou nas escolas, a concepção baseada na eficácia do uso de tecnologias para o ensino programado ou no emprego do software educacional para a melhoria da didática.

A chegada da web às escolas públicas ${ }^{29}$ coincidiu, historicamente, com a inversão das tendências aparentemente (e de certa forma, artificialmente) opostas, que contrapunham cognitivistas/construtivistas (filiados epistemologicamente aos postulados de Piaget) e sociointeracionistas (partidários da idéias de Vigotsky e de teóricos afins).

Já em relação a Paulo Freire, observamos que sua filosofia pedagógica, nas características mais visíveis, demonstra grande preocupação em precisar o sentido e o significado (re-significado, quando necessário) das palavras, o que, quase sempre, lhe serviu como base para conhecidas dissertações (caso, por exemplo de "Extensão ou Comunicação" de 1977).

Outro ponto que se evidencia na obra de Freire é a indissociabilidade entre suas posturas políticas marcantes e sua pedagogia. Isso lhe rendeu muita incompreensão, especialmente por parte daqueles que não viam como adequado a proposta do educador pernambucano em torno da dialogicidade comunicativa, tachando todo o universo de seu pensamento como "comunista", sem levar em conta suas bases humanistas, com origem do

28 A filosofia "Construcionista" defendida por especialistas que assessoraram a implementação do projeto Gênese na Cidade São Paulo, no início dos anos 1990, invoca uma filiação direta do construtivismo piagetiano (Cf. VALENTE: 1995). Abordamos essa questão com maior profundidade no capítulo III.

${ }_{29}$ É preciso ter em mente que nos referimos ao universo da escola pública da cidade de São Paulo-SP. 
denominado "catolicismo radical”, presente junto à intelectualidade brasileira, nos anos 50 e $60^{30}$.

Embora faltem, na obra de Freire, referências explícitas a Vigotsky, enxergamos certa vinculação entre eles ${ }^{31}$, principalmente na importância atribuída à escola como espaço de interação educacional, fato que aponta para uma base pedagógica com a qual podemos trabalhar, com segurança, na construção do campo da Educomunicação.

Ainda que o rigor acadêmico nos obrigue a ser cuidadosos sobre a possibilidade e a pertinência de se "fazer conversar" pensadores oriundos de contextos tão diversos quanto a União Soviética do entre-guerras e o Brasil da ditadura militar, cabe observar que — seja pelo momento de crise institucional aguda que seus países atravessavam, seja pela preocupação de oferecer uma resposta educativa para um quadro social profundamente conturbado - existem muitas similaridades e complementaridades entre as propostas de ambos e, mais ainda: uma identidade destas com o quadro de pressupostos da Educomunicação.

De uma forma geral, podemos considerar que ambos representam estágios diferentes de uma mesma concepção sobre o papel eminentemente social da educação e da preponderância do desenvolvimento de instrumentos comunicativos como causa ${ }^{32}$ - e não conseqüência — do desenvolvimento cognitivo do indivíduo socialmente inserido.

Defendemos, pois, a idéia de uma aproximação conceitual, filosófica e, até certo ponto, metodológica, entre Lev Vigotsky e Paulo Freire, no sentido de que ambos tratam a linguagem como base da educação e objetivam, como fim, a transformação de um contexto social dentro do qual o homem (referencialmente o trabalhador) se encontra integrado.

No plano dos conceitos, podemos identificar uma aproximação entre a centralidade no processo de aquisição da linguagem que se constitui, a um tempo, construto e construtora das relações sociais. Se Pensamento e Linguagem (VIGOTSKY, 1999) pode ser considerada a pedra angular da psicopedagogia social, Pedagogia do Oprimido (FREIRE, 1992) representa o marco da concepção "Político-Pedagógica" na educação. Podemos,

30 Sobre o tema, consultar Ismar de Oliveira Soares. Do Santo Ofício à Libertação, São Paulo, Paulinas, 1988.

31 MOLL aponta que "O conhecimento escolar cresce na análise do dia-a-dia. E, em um sentido quase freireano, Vygotsky propôs que a percepção das crianças e o uso dos conceitos do cotidiano são transformados pela interação com os conceitos escolarizados. Os conceitos do di-a-dia integram-se, então, a um sistema de conhecimentos, adquirindo escolarização e controle" (MOLL: 1996,12).

32 Como aparece, por exemplo, na "Epistemologia Genética" de Piaget. 
assim, afirmar que ambas as obras devem constar como literatura obrigatória na formação de um educomunicador.

No plano filosófico, é nítida a orientação histórico-dialética de Vigotsky, não só pelo fato de sua carreira ter se desenvolvido no âmago de uma sociedade marxista em construção $^{33}$, mas pela postura de pesquisador das relações humanas que transparece em sua obra. Esta característica é bem visível, por exemplo, nas críticas dirigidas aos primeiros livros de Jean Piaget, a quem, diga-se de passagem, ele devotava respeito e admiração (VIGOTSKY, 1999: 28-29).

Já em Freire, observamos um processo de construção do raciocínio políticopedagógico alicerçado em influências gramscianas, mais tarde somadas às de Lucáks, Goldman, Amílcar Cabral e Hobsbawn (SCOCUGLIA, 1999: 100-102).

Essa análise parcial da recíproca pertinência entre as posições epistemológicas de Vigostky e Freire, será desenvolvida ao longo do texto, principalmente nos capítulos III e IV desta tese.

Acreditamos já haver delimitado o cerne de nossa problemática e as linhas argumentativas que orientarão a construção desta tese. Nas próximas páginas, apresentaremos de modo mais conciso e formal o enunciado das hipóteses que são nosso ponto de partida.

33 Como é sabido, após sua morte, sua obra seria proscrita por ordem de Stalin. 


\section{Enfoque metodológico}

Recapitulamos nossas proposições:

a presente pesquisa se reporta à "Mediação Tecnológica na Educação", expressão que denomina uma importante vertente dentro do campo emergente da Educomunicação;

dentro do âmbito - formação de formadores na escola pública, — e do escopo - discussão epistemológica e conceitual com base nos pressupostos educomunicativos - , aqui propostos, serão trabalhadas, na tese, questões relativas à origem e ao emprego do próprio termo que define o novo campo;

(3)

tais questões deverão, tanto quanto possível, ser respondidas e redimensionadas após a investigação reflexiva de material (dados e informações sistematizadas) oriundo de projetos de formação de formadores (ver subitem "amostragem”, nesta seção) e

propiciando, enfim, contribuições significativas para ampliar-enriquecerrobustecer o quadro teórico da Educomunicação e aproximar seus referenciais daqueles observados pelos “campos limítrofes” que são, aqui também, objetos de nossa investigação.

Definidos o "tema" e o "recorte temático" de nosso trabalho e admitindo, por outro lado, como tarefa ainda pendente, a necessidade de aclarar epistemologicamente o "objeto de estudo MTE"34, partimos para a apresentação da nossa proposta de pesquisa de uma forma mais sintética.

34 Fazemos aqui uma distinção entre o conceito dado de MTE — do qual partimos, amparado pela abordagem educomunicativa — e as ações identificadas (ou “enquadráveis") como MTE, as quais constituem nosso objeto declarado de estudo. 
Vejamos o quadro 1:

\begin{tabular}{|c|c|}
\hline & QUESTÃO- HI PÓTESE PRINCI PAL \\
\hline Problema & $\begin{array}{l}\text { - “Mediação Tecnológica" é uma expressão que se aplica } \\
\text { correntemente em diversos contextos educativos. Seu } \\
\text { sentido e significado, no entanto, mudam de uma referência } \\
\text { para outra, esvaziando-se. } \\
\text { - Por outro lado, há também várias denominações correntes } \\
\text { para o que se entende, em Educomunicação, como } \\
\text { processos de MTE. }\end{array}$ \\
\hline Hipótese & $\begin{array}{l}\text { - Os diferentes campos e as áreas de conhecimento, que lhes } \\
\text { são tributárias, entendem a conjunção dos termos - e os } \\
\text { próprios conceitos "Mediação" e "Tecnologia" - de uma } \\
\text { forma diferenciada, construída a partir de um discurso que } \\
\text { reflete um projeto específico de sociedade. } \\
\text { - Por um ou outro motivo, aclarar o entendimento sobre a } \\
\text { MTE é uma tarefa importante e urgente. }\end{array}$ \\
\hline $\begin{array}{l}\text { Rumos da } \\
\text { investigação }\end{array}$ & $\begin{array}{l}\text { - Buscamos o entendimento epistemológico da MTE, } \\
\text { construído a partir os diferentes usos dos termos } \\
\text { "Mediação", "Tecnologia" e da combinação entre ambos. } \\
\text { - No decorrer da investigação, nos propomos a construir um } \\
\text { modelo teórico para entender o processo de mediação, o } \\
\text { qual seja aplicável dentro de certos parâmetros de } \\
\text { operacionalidade que contemplem a MTE. }\end{array}$ \\
\hline
\end{tabular}

quadro 1: enunciado da hipótese principal

As informações dispostas acima refletem, em linhas gerais, o esforço aqui dispendido para elevar o patamar de entendimento de nosso objeto de estudo. Com igual concisão, pretendemos apresentar as derivações imediatas da questão formulada. 
Vejamos o quadro 2:

\begin{tabular}{|l}
\hline QUESTÃO-HIPÓTESES TRI BUTÁRIAS \\
\hline (1) a definição conceitual da MTE pode ajudar na \\
consolidação do arcabouço conceitual da \\
Educomunicação; \\
(2) a definçãa conceitual da MTE pode aproximar \\
epistemologicamente, por convergência, os campos da \\
Comunicação e da Educação; \\
(3) a definição conceitual da MTE pode fornecer subsídios \\
para aprimorar o planejamento, o desenvolvimento e a \\
avaliação de projetos pedagógicos de MTE na esfera das \\
políticas públicas. \\
Possíveis \\
desdobramentos \\
(1) os referenciais teóricos utilizados neste trabalho podem \\
ser assimilados por pesquisas que enfoquem as outras \\
vertentes da Educomunicação (ver capítulo I); \\
(2) analisando projetos efetivamente implementados, tanto \\
sob a perspectiva da "abordagem comunicacional" \\
quanto à da "abordagem educacional", é possível \\
estabelecer os vínculos de um pensar/agir comum aos \\
dois campos que se interseccionam na prática \\
educomunicativa; \\
(3) a sistemática desenvolvida para a avaliação do projeto, \\
que será estudado no capítulo IV, também pode se \\
tornar um referencial significativo para outras pesquisas \\
em linhas afins.
\end{tabular}

quadro 2: enunciado das hipóteses tributárias

Ainda que uma tese não necessite, em princípio, declarar explicitamente a natureza e a ordem de suas operações metodológicas (as quais permeiam seu desenvolvimento), optamos por incluir, neste bloco introdutório, esta exposição sistemática cujo ciclo se fecha 
com descrição de nossa amostra e a apresentação de nossa abordagem instrumental (incluindo as ferramentas que serão utilizadas em sua análise) ${ }^{35}$.

\section{Amostragem e Tratamento}

Mesmo pressupondo nossa afinidade conceitual com a abordagem históricodialética, observamos que a natureza específica desta pesquisa implica também no uso de técnicas investigativas de outras correntes, com predominância dos métodos qualitativos sobre os quantitativos.

O material da pesquisa que pretendemos analisar obedece a três classificações distintas, a serem trabalhadas em etapas igualmente diferenciadas no desenvolvimento sintagmático da pesquisa:

A. MATERIAL BIBLIOGRÁFICO, ao qual dedicaremos um tratamento de revisão bibliográfica (MARCONI \& LAKATOS, 2001), com o objetivo de compor um quadro conceitual significativo, apto a fornecer aportes epistemológicos e modelos para serem analisados e discutidos. Essa parte da pesquisa deverá se estender, não só ao material impresso de livros e periódicos, mas também a documentos e textos oficiais emitidos pelos órgãos governamentais envolvidos nos projetos analisados.

B. QUESTIONÁRIOS DE AVALIAÇÃO, preenchidos pelos professores da rede pública participantes, na grande maioria dos casos, dos processos de formação docente escolhidos como objeto de análise. Tais questionários compõem os relatórios finais do projeto que analisaremos com vistas à aplicação do modelo gestado no âmbito dos capítulos mais conceituais da tese (cap. IV, principalmente).

C. REGISTROS DE CORRESPONDÊNCIA ELETRÔNICA, que sintetizam, de forma detalhada, as opiniões, expectativas e concepções, referentes a MTE,

35 Atribuímos essa opção à nossa própria necessidade (ou hábito?) de enunciação didática a qual, traduzida para o universo das teorias cognitivistas (Piaget e Vigotsky), poderia ser interpretada como uma construção do conhecimento via internalização do diálogo. 
manifestas pelos participantes dos projetos analisados. Entendemos que tais registros podem contribuir para o entendimento e avaliação dos projetos enfocados.

Quanto ao universo da amostra, dentro do qual estão circunscritos os materiais de pesquisa relacionados nos itens "B" e "C", podemos delimitá-lo de acordo com o projeto de MTE aqui analisado, conforme exposto no quadro 3:

\begin{tabular}{|cc|}
\hline PROJ ETO & FORMAÇÃO CONTI NUADA EM Mí DI AS NA EDUCAÇÃO \\
\hline $\begin{array}{c}\text { Período de } \\
\text { desenvolvimento }\end{array}$ & agosto de $2006^{36}$ a abril de 2007 \\
\hline Âmbito geográfico & 92 Diretorias de Ensino da SEE (Estado de São Paulo) \\
\hline Modalidade & formação a Distância \\
\hline Educadores envolvidos & cerca de 2.000 \\
\hline Finalidade & Extensão Universitária \\
\hline
\end{tabular}

quadro 3: universo da amostra pesquisada

No que tange às ferramentas específicas para análise do material relacionado no item "A", faremos uso privilegiado das ferramentas oriundas da análise comparativa, da etimologia, lingüística pragmática, particularmente daquelas vinculadas à "Teoria da Relevância" (SPERBER \& WILSON, 2001). Em nosso entender, elas proporcionam um substrato rico e consistente de procedimentos operatórios não mecaniscistas, os quais, pela objetividade (no sentido de "imparcialidade") e facilidade didática de compreensão aqui pretendidas, revelam-se mais interessantes que os procedimentos semióticos, como, por exemplo, a análise do discurso ${ }^{37}$.

Embora aqui esteja esboçada, em linhas gerais, a orientação metodológica básica a ser observada, julgamos necessário complementar esta seção de uma forma mais abrangente, esclarecendo nosso trabalho metodológico a partir de Instâncias da pesquisa, conforme propõe LOPES (2003: 119) em seu Modelo Metodológico.

\footnotetext{
36 Na verdade, o curso propriamente dito tem um histórico anterior de desenvolvimento. Referimo-nos, aqui ao período que constará em nossa análise.

Mea culpa: que pese aqui também, nossa falta de domínio do arcabouço teórico da semiótica, pelo menos, em um nível que nos permita trabalhar confortavelmente no plano conceitual, condição sine qua non devida ao grau de complexidade inerente à nossa tarefa.
} 


\section{Instâncias da Pesquisa}

\section{Instância Epistemológica}

Além dos pontos relevantes já descritos nos itens anteriores, tais como objeto da pesquisa, objetivos e QTR, do encadeamento tema/recorte/problema/hipóteses e do perfil da amostra e do universo da pesquisa, torna-se necessário evidenciar o paradigma epistemológico que servirá de apoio para o desenvolvimento e a construção da tese.

Não obstante a organização dos dados coletados — boa parte dos quais a partir de fontes documentais - pareça remeter às estratégias de trabalho identificadas como estrutural-funcionalismo (LOPES, 2003: 41), o viés crítico que aqui se busca, em conjunto com a reconstituição histórica do objeto de estudo (baseada nos depoimentos dos agentes nele envolvidos), almeja o predomínio da Pesquisa Crítica enquanto abordagem epistemológica.

Muitos dos autores que compõem o QTR específico do trabalho demonstram uma postura crítica em relação ao uso da tecnologia em processos educativos, ainda que de maneira totalmente diversa dos pensadores da linha funcionalista.

Quanto aos demais autores e obras relacionados em nossa bibliografia complementar, constituem fonte de conceitos-chave e diretrizes procedimentais para a pesquisa, isto é, das técnicas de coleta e interpretação de dados.

É interessante notar que nossa proximidade com o objeto de estudo — o projeto de MTE estudado representa uma vivência acadêmica e profissional recente e presente oferece inúmeras possibilidades de acesso aos dados e informações sobre os mesmos. Isso ocorre, tanto na forma de registros oficiais (estatísticas, relatórios), quanto no contato com as fontes "humanas" (cursistas, tutores, mediadores) que oferecem o contraponto de uma percepção diferenciada daquela assumida pelas instituições. 


\section{Instância Teórica}

Além de tudo o que já relatamos, pode-se acrescentar a divisão da bibliografia de suporte conceitual do QTR a partir de três correntes:

(a) os autores principais, tanto da área comunicacional quanto da educacional, os quais, ainda que com alguma brevidade, deverão ser examinados para fundamentar o capítulo introdutório e as considerações finais;

(b) os autores que tratam especificamente dos conceitos de "mediação", "MT" e "MTE", referidos dentro da tarefa de apoiar nossa análise a partir de bases semânticas, culturais e até lingüísticas (etimologia e análise sintática); e

(c) aqueles que poderíamos chamar de "filósofos digitais", pensadores contemporâneos que se dedicam a suscitar debates envolvendo Mídia, Tecnologia e Educação. Tais aportes são valiosos quando se pretende confrontar o caráter instrumental do qual a MTE, por vezes, se reveste, e resgatar a perspectiva crítico-dialética que nos motiva.

Numa categoria à parte, estão os autores de referência, tais como os compiladores e os colaboradores de dicionários e tomos enciclopédicos.

\section{Instância Metódica}

A articulação de sentido no texto identifica-se, segundo LOPES (2003, 126-128), pelo emprego de duas operações: a exposição e a causação.

Podemos apontar que a operação da exposição basear-se-á em

(a) estabelecimento de parâmetros e categorias a partir das quais possamos pré-determinar uma ordem e uma importância epistemológica aos elementos analisados; 
(b)

apresentação de conceitos fundantes nas áreas de Comunicação, Educação e Tecnologia que permitam a identificação de matrizes conceituais presentes no universo da MTE;

(c) contraposição das idéias fundamentadas pelos diferentes autores constantes no QTR anterior em relação aos princípios norteadores verificados empiricamente na prática dos projetos analisados;

(d) interpretação e exposição das inferências obtidas no processo de desenvolvimento, bem como de seus possíveis desdobramentos.

No tocante ao último item (letra "d"), notamos que a interpretação dos fatos verificados e seu alinhamento dentro do referencial teórico extraído da Educomunicação, consistirão nas principais atividades ligadas à causação.

\section{Instância Técnica}

Finalizando esta apresentação sobre os aspectos metodológicos dos quais pretendemos fazer uso, cabe ressaltar a aproximação, em alguma medida, com as técnicas de pesquisa participante (BRANDÃO: 1999) e pesquisa-ação (THIOLLENT: 2000). Esta aproximação se reflete na busca por subsídios que possam aferir a aplicabilidade dos conceitos às práticas educativas correntes em MTE, a partir da investigação do projeto de formação de formadores com o qual nos envolvemos direta e ativamente.

Para tanto, além de uma base filosófica consistente e de referenciais epistemológicos significativos em todos os campos pesquisados, temos a destacar como fontes primárias de dados e informações na pesquisa:

1. o registro formal e informal de dirigentes (ou administradores) e educadores (ou mediadores) envolvidos na organização e execução das estratégias de MTE dentro da rede escolar pública; 
2. o conjunto dos documentos legais e normas técnicas emanados pelo MEC com a intenção de regular e nortear a educação a distância em território nacional e o material on-line disponibilizado pela SEED-MEC relatando detalhadamente o desenvolvimento da plataforma EaD e-Proinfo (no caso do "Formação Continuada sm Mídias na Educação");

3. material em vídeo, áudio e fotos, registrando encontros e eventos de formação onde se realizam a discussão sobre a $\mathrm{MTE}^{38}$.

A especificidade no recorte da pesquisa bem como a ênfase dedicada à questão central da Mediação nesta tese, acarreta o uso privilegiado de determinadas fontes em relação a outras, mas vale dizer que o material levantado foi essencial, em todo o seu conjunto, influindo, direta ou indiretamente no quadro de conclusões apresentado ao final.

Para finalizar o bloco introdutório, faremos constar de forma sucinta, a estrutura da tese na forma de tópicos por ela abordados.

\section{Estrutura desta Tese}

A organização deste trabalho, escrito em capítulos e seções, procura obedecer a uma lógica que caminha da especificidade do tema tratado em direção a um espaço que propicie generalizações, as quais, quiçá, contribuam para aprofundar a questão colocada a priori.

Os referenciais mencionados nesta introdução reaparecerão em toda a extensão do texto, revisitados e assimilados ao nosso objeto de estudo. As possíveis relações de causalidade e correspondência entre nossas categorizações e os casos analisados fornecerão subsídios para nossas considerações.

38 Material auxiliar consultado em caráter de ilustração ou como tema-gerador (no sentido freireano) da discussão epistemológica que suscitamos. 
O corpo do texto se distribui em quatro capítulos de desenvolvimento e um bloco final de conclusões. O desenvolvimento, capítulo a capítulo, está estruturado da seguinte forma:

\section{Seção inicial:}

- Introdução: Escopo e Âmbito desta tese

- I. Fundamentação Educomunicativa

1.1 Entendendo a Educomunicação: discussões preliminares: 1.1.1 Compreensão epistemológica da Educomunicação/1.1.2 Compreensão histórica da Educomunicação e de suas áreas de intervenção (vertentes)/1.1.3 A vertente educomunicativa da MTE.

1.2 Breve histórico analítico dos projetos do NCE: 1.2.1 Educom.TV/1.2.2 Educom.rádio São Paulo/1.2.3 Educom.rádio Centro-Oeste/1.2.4 Educom.Geração Cidadã/1.2.5 Outros projetos/1.2.5.1 Educom.Saúde/1.2.5.2 Tôdeolho.TV/1.2.5.3 Educom.CSL (Colégio São Luís)/1.2.5.4 Educom.Fundhas.

\section{Seção Conceitual:}

\section{- II. MTE: a construção de um sentido}

2.1 Para que serve fixar um sentido?/2.1.1 Mediação: uso ou abuso lexical?/

2.2 O conceito de mediação e suas transformações históricas/ 2.2.1 A mediação na Filosofia Clássica/2.2.2 A mediação em Hegel/2.2.3 A mediação na Filosofia Marxista. 2.3 A teoria das mediações: 2.3.1 As contribuições de Serrano/2.3.2 As contribuições de Martín-Barbero/2.3.3 As contribuições de Orozco Gómez;

2.4 Etimologia de "Meio" e "Mediação" no Latim;

2.5 Etimologia de "Meio" e "Mediação" no idioma inglês.

\section{- III. MTE: a construção de um significado}

3.1 Significados construídos, significados a construir: 3.1.1 Esclarecendo sobre Vigotsky 3.2 Modelos visuais para entender a Mediação: 3.2.1 Modelo Gráfico Elementar/ 3.2.2 Modelos Gráficos Culturais/3.2.2.1 O modelo matemático de comunicação/3.2.2.2 O processo de comunicação humana de Bordenave/ 3.2.2.3 A ZDP e a dupla natureza da mediação/ 3.2.2.4 O modelo de análise das situações midiatizadas de ALAVA (2002)/3.2.3 Interpretação sobre os modelos gráficos/3.2.4 A Metáfora da Orquestra. 


\section{Seção Analítica-interpretativa:}

\section{- IV. MTE: a história de um conceito}

4.1 A história de um conceito: 4.1.1 Um conceito para a Tecnologia/4.1.2 Integração da tecnologias na escola/4.1.3 Nomes diferentes para uma mesma idéia;

4.2 O elemento Político-Pedagógico, ou "um debate histórico";

4.3 Sobre o mediador: o exemplo emblemático do POIE $^{39}: 4.3 .1$ O Projeto Gênese e os primórdios da MTE na rede pública/ 4.3.2 Visão Público-Institucional e Visão TecnoCorporativa;

4.4 O MEC e as políticas públicas da MTE: 4.4.1 O e-Proinfo/ 4.4.2 O curso Formação Continuada em Mídias na Educação.

\section{- Considerações Finais}

Sobre esta seção final;

a) possíveis itinerários na leitura deste trabalho;

b) contribuições conceituais da pesquisa;

c) contribuições metodológicas da pesquisa;

d) tendências e pontos para desenvolvimento futuro; e

e) prováveis omissões e incompletudes.

\section{Seção Documental}

- Referências: Bibliografia básica/Bibliografia específica/Bibliografia complementar/ Bibliografia eletrônica.

- Anexos: Guia didático do Tutor (do curso Formação Continuada em Mídias na Educação).

39 Sigla do cargo de Professor Orientador de Informática Educacional. 


\section{CAPÍTULO I}

\section{FUNDAMENTAÇÃO EDUCOMUNICATIVA}




\subsection{Entendendo a Educomunicação: discussões preliminares}

A identidade das coisas, o fato de que possam assemelhar-se a outras e aproximar-se delas, sem contudo se dissiparem, preservando sua singularidade, é o contrabalançar constante da simpatia e da antipatia que o garante. (FOUCAULT, 1999: 34)

O conceito de Educomunicação ${ }^{40}$ adotado como ponto de partida para esta pesquisa designa, em conformidade com as pesquisas do NCE/USP, o "conjunto de ações envolvendo ou não as tecnologias da informação - que permitem que educadores, comunicadores e outros agentes sociais promovam e ampliem as relações de comunicação entre as pessoas que compõem a comunidade educativa" (SOARES, 2000).

Aqui temos contemplados cinco aspectos recorrentes nos estudos educomunicativos em geral e também na particularidade de nosso objeto de estudo, sendo:

(a) a Educomunicação é uma proposta destinada a transformar qualitativamente a realidade por meio de ações comunicativas coordenadas;

(b) a postura crítica em relação ao aparato tecnológico, tomada não apenas como herança dos estudos da media literacy, mas também como contraponto às posturas "tecnocêntricas" que dominam o cenário educativo escolar;

(c) a transdisciplinaridade ${ }^{41}$ (e, por conseqüência, a transversalidade curricular) converte-se em pressuposto para entender e atender as demandas enfocadas pelas diferentes facetas (social, cultural, etc.) que emergem na prática educativa;

40 O termo educomunicación ocorre, inicialmente, em textos do uruguaio Mario Kaplún, para designar atividades em torno do que se acostumou a denominar, na América Latina dos anos 70, como "educação para a comunicação", "leitura crítica dos meios" ou, de forma mais aberta, "comunicação educativa".

41 Cuja essência, segundo Ubiratan D'Ambrosio, "reside numa postura de reconhecimento onde não há espaço e tempo culturais privilegiados que permitam julgar e hierarquizar - como mais corretos ou mais verdadeiros - complexos de explicação e convivência com a realidade que nos cerca." (D'AMBROSIO, 2001: 09) 
(d) o caráter inter-relacional das ações educomunicativas é assumido como preocupação maior de criar, ampliar, consolidar e flexibilizar canais de comunicação multidirecionais e polifônicos no contexto dos ambientes em que acontece o processo educativo;

(e) o conceito de "ecossistema comunicativo"42 identifica-se com a noção de comunidade educativa desde que seja articulado transversalmente por processos comunicativos, o que pressupõe a gestão compartilhada de processos, a horizontalidade do organograma (empowerment) e o estímulo ao protagonismo.

Mais recentemente, o próprio SOARES ampliou o alcance de sua definição ${ }^{43}$, acrescendo-lhe alguns conceitos (devidamente grifados pelo autor) que, nesse segundo momento, foram enfatizados. Assim, temos como definição ampliada da Educomunicação:

\begin{abstract}
“o conjunto das ações inerentes ao planejamento, implementação e avaliação de processos e produtos destinados a criar e fortalecer ecossistemas comunicativos em espaços educativos, melhorar o coeficiente comunicativo das ações educativas, desenvolver o espírito crítico dos usuários dos meios massivos, usar adequadamente os recursos da informação nas práticas educativas, e ampliar a capacidade de expressão das pessoas" (SOARES, 2005).
\end{abstract}

Podemos afirmar que os acréscimos e, de certa forma, a omissão das Tecnologias da Informação refletem o avanço do estado de arte da Educomunicação ${ }^{44}$, o qual se deve, em grande medida, à implementação de diversas pesquisas que aderiram à premissa de emergência do novo campo.

O NCE (Núcleo de Comunicação e Educação) da ECA-USP, já mencionado na introdução desta tese, destaca-se pelo número considerável de trabalhos produzidos sobre o

42 A expressão é recorrente na literatura educomunicativa. Uma definição cabível seria a de um "conjunto de relações, de ações e de condições — poderíamos chamar de forças — que interagem mutuamente, envolvendo a todos numa grande força comunicativa capaz de influenciar as instituições, os destinatários (educandos) e os agentes (educadores), bem como os conteúdos e as metodologias educativas e comunicacionais" (SILVA FILHO: 2004, 14).

43 Note-se que a definição aqui transposta é a mesma constante na nota de rodapé da página 02 de nossa introdução.

44 Entendemos que as abordagens que analisam o fenômeno da MTE e que se respaldam nas terminologias TI (Tecnologias da Informação), TICs (Tecnologias da Informação e Comunicação) ou NTICs (Novas Tecnologias da Informação e Comunicação) evidenciam uma compreensão fragmentada sobre o papel sociocultural da Tecnologia. 
tema "Educomunicação" e sobre as interfaces comunicativo-educativas. Trata-se de dissertações e teses acadêmicas, como já referendados na Introdução, assim como de relatórios de projetos implementados, ou mesmo textos avulsos, parte dos quais pode ser acessada no site da entidade, no endereço http://www.usp.br/nce.

De nossa parte, acrescentaremos algumas reflexões sobre os conceitos educomunicativos emanadas com base em nossa própria experiência enquanto mediadores de processos educativos, empregando tecnologias com diferentes modalidades e graus de sofisticação ${ }^{45}$.

Partindo da constatação de que, enquanto campos epistemológicos consolidados, a Educação e a Comunicação objetivam intervir proativamente na sociedade de uma forma que coincide em vários pontos, podemos extrapolar a delimitação formal entre uma e outra, analisando seus diferentes papéis na perspectiva de processos.

Assim, consideramos que, ao longo da história, "os grupos humanos têm desenvolvido de forma progressivamente mais (ou menos) sistemática processos educativos e processos comunicativos, ambos entendidos basicamente como ações objetivas direcionadas para a organização e a transmissão de conhecimentos de um indivíduo a outro" (CONSANI: 2007, 10).

Essa pressuposição nos leva a pensar no sentido histórico da separação (considerando-se que, num dado momento, eles foram efetivamente separados) entre os processos comunicativos e educativos, o que faz ressaltar não mais seu paralelismo, mas sim, suas divergências ${ }^{46}$.

Vejamos, a seguir, o quadro 4:

$45 \quad$ A origem dessas idéias pode ser encontrada no pequeno manual paradidático publicado com o título Como usar o Rádio na Sala de Aula (CONSANI, 2007). Além das vivências que relatamos na introdução desta tese, há uma lista expressiva das vivências que relacionamos ao nosso trabalho na educação formal, principalmente, na docência superior em cursos de Comunicação Social (vide "Créditos do Autor", na seção final deste volume).

$46 \quad$ "A história nos ensina, na verdade, que tanto a educação quanto a comunicação, ao serem instituídas pela racionalidade moderna, tiveram seus campos de atuação demarcados, no contexto do imaginário social, como espaços independentes, aparentemente neutros, cumprindo funções específicas: a educação administrando a transmissão do saber necessário ao desenvolvimento social e a comunicação responsabilizando-se pela difusão das informações, pelo lazer popular e pela manutenção do sistema produtivo através da publicidade." (SOARES: 2000b, 13) 


\begin{tabular}{|c|c|c|}
\hline ASPECTO ANALISADO & $\begin{array}{l}\text { PROCESSOS } \\
\text { COMUNICATIVOS }\end{array}$ & $\begin{array}{l}\text { PROCESSOS } \\
\text { EDUCATIVOS }\end{array}$ \\
\hline Alcance pretendido: & $\begin{array}{l}\text { âmbito geográfico: } \\
\text { propagação no espaço; }\end{array}$ & $\begin{array}{l}\text { âmbito histórico: } \\
\text { perpetuação no tempo. }\end{array}$ \\
\hline Dinamicidade: & busca da mobilidade; & busca da estabilidade. \\
\hline Transmissibilidade: & por irradiação (impessoal); & por contágio (pessoal). \\
\hline Propósito: & por vezes, espontaneísta; & sempre utilitarista. \\
\hline Vetorialidade: & $\begin{array}{l}\text { preferencialmente } \\
\text { bidirecional; }\end{array}$ & $\begin{array}{l}\text { preferencialmente } \\
\text { unidirecional. }\end{array}$ \\
\hline $\begin{array}{l}\text { Ênfase interpessoal } \\
\text { (dimensão micropolítica): }\end{array}$ & situada no receptor; & situada no emissor. \\
\hline $\begin{array}{l}\text { Ênfase intersocial } \\
\text { (dimensão macropolítica): }\end{array}$ & $\begin{array}{l}\text { independência do poder } \\
\text { constituído; }\end{array}$ & $\begin{array}{l}\text { integração ao poder } \\
\text { constituído. }\end{array}$ \\
\hline
\end{tabular}

\section{quadro 4: aspectos divergentes entre processos comunicativos e educativos}

De maneira sintética, propomos essa ilustração que, malgrado sua validade e generalidade limitadas ${ }^{47}$, serve para delimitar a fronteira imaginária convencionalmente estabelecida entre os dois campos. É claro que há muitos mais elementos de contraposição (e de aproximação) entre os dois campos, e poderíamos dedicar um maior espaço que a essa dinâmica de comparações, reforçando, por exemplo, sua leitura sociológica ${ }^{48}$. Para os usos e fins desta tese, entretanto, esse grau de discussão nos parece suficiente. Voltaremos ao quadro ilustrativo ainda nesta seção, para nele incluirmos os processos educomunicativos em sua especificidade.

\footnotetext{
47 Mais ainda pela convergência e intercâmbio crescentes entre Comunicação e Educação, tema central do presente capítulo. Outro ponto que merece ser destacado é a indistinção que fazemos, nesta comparação, entre a "Comunicação/campo epistemológico" e a "Comunicação/atividade social", esta última personificada, geralmente, nos meios de comunicação. Acreditamos que essa generalização um tanto forçada nos permite um paralelo que equilibra a dicotomia também existente entre a "Educação/Pedagogia" e a "Educação/instituição", esta última identificada, no mais das vezes, com a Escola.

48 Educação e comunicação distanciam-se, também, pelo tecido de seus discursos. O discurso educacional é mais fechado e enquadrador, oficial, mais autorizado. Validado por autoridades, não é questionado. Nesse sentido, é autoritário, posto que é selecionado e imposto em forma de currículo a alunos e professores. O discurso comunicacional, ao contrário, é desautorizado, desrespeitoso e aberto, no sentido de que está sempre à procura do novo, do diferente, do inusitado. (SOARES: 2000b, 18)
} 


\subsubsection{Compreensão epistemológica da Educomunicação}

Podemos afirmar que, apesar de configurarem seus respectivos estatutos a partir de processos distintos, a Comunicação e a Educação convergem, a cada dia mais, no que tange a seus objetivos sociais, objetos de estudo e métodos de abordagem ${ }^{49}$.

Tal convergência é verificada em outros campos e áreas do conhecimento, e esse fenômeno de melting pode ser entendido como um fato sociocultural amplo (tendência "globalizante"?) ou como um alinhamento geral de áreas de conhecimento polarizadas pela Tecnologia (sustentando e sendo sustentada pelo capitalismo ultraliberal), a qual, no vácuo de ideologias e crenças da pós-modernidade, parece catalisar a atenção geral, seja do senso comum, seja da pesquisa acadêmica ${ }^{50}$.

Podemos pensar também que vivemos num ciclo final de reflexões epistemológicas pautado pela insuficiência das matrizes e modelos oriundos da Psicologia - os quais haviam, por sua vez, destronado os ditames da Escolástica na virada do século anterior.

Esse virtual esgotamento da epistemologia não equivale a uma superação pura e simples dos modelos anteriores, mas tão somente ao surgimento de novos problemas e novas respostas, circunstancialmente mais interessantes para a academia — por sua atualidade, ou seu "ineditismo" — e mais "populares" no âmbito do senso comum — pelo poder avassalador do marketing.

Assim, no campo da Educação, enquanto na primeira metade do século XX o foco das discussões epistemológicas era a natureza da inteligência e se a construção da cultura/visão de mundo se consolidaria nos planos individual e social, nesta primeira década do século XXI, vemos predominar conceitos como "interatividade dos meios", "conectividade em rede" e outras digressões técnicas, apresentadas como solução para as demandas pendentes de formação continuada e de gestão democrática dos espaços educativos.

\footnotetext{
49 "A possibilidade de interlocução entre diferentes campos de saberes pode revelar a transversalidade da produção de conhecimentos científicos sobre questões que envolvem a comunicação e a educação, que necessitem de reflexões teóricas, de unidades com práticas acadêmicas separadas e departamentalizadas, mas não de todo distintas" (SCHAUN: 2002, 31).

50 Ainda é cedo para fecharmos uma posição: falta-nos a perspectiva histórica do momento atual.
} 
Já no campo da Comunicação - após a superação do embate entre o ativismo filosófico de inspiração humanista/socialista (paradigma crítico-cultural, engendrado na Europa) e o descricionismo técnico, ávido por um modelo absoluto (paradigma informacional/funcionalista, consolidado nos E.U.A.) -, o que observamos é a pulverização dos estudos em diversas correntes periféricas. Estas, tendo subvertido o locus dos fóruns de discussão para a América Latina, demonstram-se muito mais interessadas nos espaços intermediários - interfaces, mediações - a partir dos quais podemos estabelecer pontes de diálogo entre as áreas do conhecimento, do que na reedição dos debates oriundos da Escola de Frankfurt ${ }^{51}$.

Foi justamente o interesse da área de Comunicação no conceito e nas práticas da mediação - processos e interfaces - que abriu o caminho para o surgimento de abordagens inovadoras e ousadas, invadindo, por assim dizer, um território já demarcado pelos campos institucionalizados.

Assim, quando a Educomunicação assoma no horizonte das pesquisas comunicativas, afigura-se como uma constatação do conjunto de fenômenos que não cabem mais, confortavelmente, nos sistemas preestabelecidos. Só para ficarmos num exemplo ratificado pelo governo (MEC, FUNDESCOLA ${ }^{52}$ ), ONGs nacionais (ANDI ${ }^{53}$, $\mathrm{CONSED}^{54}, \mathrm{IAS}^{55}$ ) e internacionais (UNICEF) e um núcleo de pesquisa acadêmica $\left(\mathrm{NEMP}^{56}\right)$, podemos mencionar o Fórum Mídia e Educação ${ }^{57}$, cujo relatório, publicado no ano seguinte, recomendava:

Reconhecer a inter-relação entre Comunicação e Educação como um novo campo de intervenção social e de atuação profissional, considerando que a informação é um fator fundamental para a Educação. O desenvolvimento tecnológico abriu novos campos de atuação e criou espaços de convergência de saberes (MEC: 2000, $31)$.

Logo, a constatação torna-se reflexão em tempo real, na medida em que muitos de seus estudiosos se vêem envolvidos em práticas educomunicativas e muitos educomunicadores passam a fazer dela seu objeto de estudo (SOARES, 2000b).

\footnotetext{
51 Definitivamente, os “integrados" parecem ter superado os "apocalípticos” (ECO, 2001).

52 Fundo Nacional de Desenvolvimento da Educação: vide glossário.

53 Agência de Notícias dos Direitos a Infância: vide glossário.

54 Conselho Nacional de Secretários da Educação: vide glossário.

$55 \quad$ Instituto Ayrton Senna: vide glossário.

$56 \quad$ Núcleo de Estudos sobre Mídia e Política da UnB (Universidade de Brasília): vide glossário.

$57 \quad$ Realizado em São Paulo entre 11 e 13 de novembro de 1999.
} 
Então, quase imediatamente, a Educomunicação transforma-se numa proposição, pois o que se detecta — pela reflexão em torno dos fenômenos constatados — é:

(a) que ela surge por ser necessária, pois a sociedade historicamente constituída do presente demanda modalidades de gestão comunicacional e educativa ${ }^{58}$ que não se sustentam unicamente na Comunicação ou na Educação atuando como campos isolados/independentes;

(b) que a convergência entre prática social e interesse epistemológico de grande parte dos educomunicadores — identificados como agentes mediadores dos processos educomunicativos - não é fortuita, mas reflete a coerência atitudinal necessária para a efetivação desses $\operatorname{processos}^{59}$;

(c) que o corpus teórico do novo campo é uma construção colaborativa em permanente processo de ampliação-ratificação-retificação.

Surge, finalmente, a necessidade de se propor e estruturar um novo sistema que comporte a Educomunicação com um estatuto e métodos próprios.

Segundo SOARES (1999a), um dos indícios da existência do novo campo é o fato de que o mesmo "já pensa a si mesmo, produzindo uma metalinguagem, elemento essencial para sua identificação como objeto autônomo de conhecimento" (SOARES: 1999a, 19).

Com base nas informações levantadas em várias pesquisas transcorridas na última década, podemos sugerir uma terceira instância dentro do quadro ilustrativo ${ }^{60}$ de comparação entre processos comunicativos/educativos (quadro 5), na qual localizamos a especificidade dos processos que a Educomunicação envolve:

$58 \quad$ O que é particularmente verdadeiro no que se refere às Políticas Públicas, como atesta o trabalho de ALVES (2007).

59 Ponto desenvolvido no subitem "Agentes da Mediação".

60 O qual, por sua vez, desenvolve as idéias sintetizadas no quadro 04, na página 42. 


\begin{tabular}{|c|c|c|c|}
\hline $\begin{array}{l}\text { ASPECTO } \\
\text { ANALISADO }\end{array}$ & $\begin{array}{l}\text { PROCESSOS } \\
\text { COMUNICATI VOS }\end{array}$ & $\begin{array}{l}\text { PROCESSOS } \\
\text { EDUCOMUNI CATI VOS }\end{array}$ & $\begin{array}{l}\text { PROCESSOS } \\
\text { EDUCATIVOS }\end{array}$ \\
\hline $\begin{array}{l}\text { Alcance } \\
\text { pretendido: }\end{array}$ & $\begin{array}{l}\text { âmbito geográfico: } \\
\text { propagação no } \\
\text { espaço; }\end{array}$ & $\begin{array}{l}\text { âmbitos geográfico e } \\
\text { histórico, propagação e } \\
\text { permanência; }\end{array}$ & $\begin{array}{l}\text { âmbito histórico: } \\
\text { permanência no } \\
\text { tempo. }\end{array}$ \\
\hline Dinamicidade: & $\begin{array}{l}\text { busca da } \\
\text { mobilidade; }\end{array}$ & busca da mobilidade; & $\begin{array}{l}\text { busca da } \\
\text { estabilidade. }\end{array}$ \\
\hline Transmissibilidade: & $\begin{array}{l}\text { irradiação } \\
\text { (impessoal); }\end{array}$ & $\begin{array}{l}\text { Irradiação e contágio } \\
\text { (impessoal/pessoal); }\end{array}$ & $\begin{array}{l}\text { contágio } \\
\text { (pessoal). }\end{array}$ \\
\hline Propósito: & $\begin{array}{l}\text { por vezes, } \\
\text { espontaneísta; }\end{array}$ & $\begin{array}{l}\text { espontaneísta nos } \\
\text { meios, utilitarista nos } \\
\text { fins; }\end{array}$ & $\begin{array}{l}\text { sempre } \\
\text { utilitarista. }\end{array}$ \\
\hline Vetorialidade: & $\begin{array}{l}\text { preferencialmente } \\
\text { bidirecional; }\end{array}$ & multidirecional; & $\begin{array}{l}\text { preferencialmente } \\
\text { unidirecional. }\end{array}$ \\
\hline $\begin{array}{l}\text { Ênfase } \\
\text { interpessoal } \\
\text { (dimensão } \\
\text { micropolítica): }\end{array}$ & $\begin{array}{l}\text { situada no } \\
\text { receptor; }\end{array}$ & $\begin{array}{l}\text { situada em ambos os } \\
\text { pontos, com ênfase no } \\
\text { processo (mediação); }\end{array}$ & $\begin{array}{l}\text { situada no } \\
\text { emissor. }\end{array}$ \\
\hline $\begin{array}{l}\text { Ênfase intersocial } \\
\text { ( dimensão } \\
\text { macropolítica) }\end{array}$ & $\begin{array}{l}\text { independência do } \\
\text { poder constituído; }\end{array}$ & $\begin{array}{l}\text { parceria com o poder } \\
\text { constituído; }\end{array}$ & $\begin{array}{l}\text { integração ao } \\
\text { poder constituído. }\end{array}$ \\
\hline
\end{tabular}

Quadro 5: aspectos divergentes entre processos comunicativos, educomunicativos e educativos

Note-se que a Educomunicação não representa, em seus diferenciais, a soma ou acúmulo das características associadas à Educação ou à Comunicação. Tampouco tenta se colocar como uma espécie de "terceira via", apaziguando as relações tensas e contraditórias entre um campo e outro.

$\mathrm{Na}$ verdade, somos obrigados a admitir que aquilo que o quadro expõe, em seus limites, é justamente sua limitação como modelo de enquadramento dos fatos analisados, verdade que corre o risco de aplicar-se a todos os modelos comparativos semelhantes. Por isso mesmo, a única tarefa cabível, em nossa visão, é a de reconstruir e remodelar os conceitos e práticas que bem serviram, durante décadas, para distribuir diligentemente os papéis que a Comunicação e a Educação deveriam desempenhar na sociedade. 
É claro que compor esse "paradigma educomunicativo" não é tarefa simples ou fácil, considerando-se que a agenda das pesquisas em Educomunicação dilui-se entre a sistematização das experiências já realizadas (ou ainda em curso) e o estabelecimento de pontes conceituais com áreas de interesse convergentes ${ }^{61}$, como bem atesta o curriculum de ações do $\mathrm{NCE}^{62}$.

Em síntese: seja por uma sucessão processual de tendências, seja pela premência de um quadro social instável, nunca se apresentaram tantas e tão convincentes oportunidades de aproximação epistemológica entre a Educação e a Comunicação. Dentro desse $\operatorname{contexto}^{63}$, cabe afirmar que a Educomunicação pode não ser a única proposta, mas é a nossa proposta.

\subsubsection{Compreensão histórica da Educomunicação e de suas áreas de intervenção (vertentes)}

A história da Educomunicação ainda está para ser contada. Sua origem pode ter começado em algum momento indistinto, por iniciativa de um educador em busca de maiores recursos expressivos ${ }^{64}$, ou de um comunicador (antes mesmo de cunhado o termo) que tenha assumido responsabilidades pedagógicas.

$\mathrm{Na}$ verdade, o que importa é reconhecer que ela já se evidenciava no início do século XX, tendo perpassado as discussões em torno da Indústria Cultural suscitadas pela Escola de Frankfurt e ganho especial atenção com o estabelecimento de uma cultura audiovisual, particularmente pelo viés da análise crítica das mensagens dos meios (SOARES: 1999a, 20) .

\footnotetext{
61 Podemos dizer que nossa tese preocupa-se mais com a segunda do que com a primeira dessas tarefas. 62 Vide a seção 1.2, ainda neste capítulo.

63 Entendendo esta tese como contribuição à linha de pesquisa e ao núcleo acadêmico que a acolhe.

64 Nessa linha, chegaríamos retroativamente, talvez, às formas teatrais das Moralidades, Autos e Mistérios da Alta Idade Média.
} 
Ainda é SOARES quem nos relata como

...paralelamente às preocupações com o fenômeno produção/recepção de bens simbólicos, iniciaram-se, especialmente a partir dos anos 70 , práticas pedagógicas em torno do binômio Educação/Tecnologias da Informação. Tais iniciativas não chegaram, ao menos na América Latina, a sensibilizar o sistema educativo, em seu conjunto, ao menos até o início dos anos 90, quando pela pressão do marketing e pelo barateamento dos equipamentos, o computador chegou, definitivamente aos centros urbanos e às salas de aula. (op. cit., 22).

Esse momento de transição importante marca também nosso primeiro contato com a tecnologia ${ }^{65}$, iniciando um longo ciclo de assimilação intelectual pautado, sucessivamente, por fases de desconfiança, admiração ingênua, dependência psicológica e assimilação crítico-reflexiva (na qual, pensamos, nos encontrar agora, emitindo tais juízos). Encerrando o resgate histórico menos que sucinto aqui apresentado, somos obrigados a reconhecer que nosso objeto de estudo quedaria extremamente reduzido sem a explosão das redes mundiais (leia-se: Internet), as quais recolocaram, por assim se dizer, a tecnologia digital dentro de uma linha epistemológica estruturada pelo viés da mediação.

Quanto à Educomunicação, podemos dizer que uma fase decisiva em sua história tem como divisor de águas justamente a pesquisa temática realizada com financiamento da FAPESP, entre 1997 e 1999, pela equipe de pesquisadores do NCE-ECA/USP e do DEPCOM/UNIFACS ${ }^{66}$, sob a coordenação do professor Ismar de Oliveira Soares (ver anexo XX). As conclusões mais eloqüentes alcançadas pelo relatório dão conta de que "a inter-relação entre a Comunicação Social e a Educação ganhou densidade própria e se afigura como um campo de intervenção social específico" (op. cit.,19) ${ }^{67}$.

A pesquisa baseou-se na coleta de dados por meio de questionários e entrevistas em profundidade, contando ainda com informações levantadas nos simpósios e congressos promovidos pelo NCE no biênio $1997-1998^{68}$. O universo da pesquisa foi composto por

\footnotetext{
$65 \quad$ Vide relatos constantes na Introdução desta tese.

66 Departamento de Comunicação Social da Universidade das Faculdades Salvador, Bahia.

67 Por sua importância enquanto marco referencial da Educomunicação, a pesquisa em questão será mencionada com bastante freqüência neste e nos próximos capítulos. Por essa razão, nos referiremos a ela como "a pesquisa perfil do NCE".

68 Apontamos o I Congresso Internacional em Comunicação e Educação e o I Primeiro Encontro Mundial de Comunicação e Educação — ambos promovidos pelo NCE/USP em co-patrocínio com o World Council of Media Education (WCME) - e dois workshops também organizados pelo NCE com a participação, respectivamente, de Jesus Martín-Barbero (12/08/1997) e de Dov Shinar (19/09/1997).
} 
uma amostragem de quase duas centenas de especialistas do Brasil e de outros oito países latino-americanos, além da Espanha (ALVES: 2007, 22-23). Os dados sistematizados passaram por um processo de tabulação e interpretação que resultou num apanhado de doze tópicos que consistem no cerne do relatório final desse trabalho.

A importância desse relatório e das conclusões obtidas com base nele ainda é objeto de avaliação em sua abrangência e mérito, principalmente por obra dos pesquisadores ligados ao $\mathrm{NCE}^{69}$. Por ora, admitimos que a maior parte das informações sobre a Educomunicação apresentadas nesta tese alimenta-se do material citado, que serve também como base para as reflexões conceituais e epistemológicas aqui desenvolvidas.

$\mathrm{O}$ conjunto dos "pontos de vista convergentes sobre a relação Comunicação/Educação" (op.cit., 26), as hipóteses levantadas na pesquisa perfil, bem como os modos de ação detectados (identificados com as áreas de intervenção educomunicativas, serão sintetizados nos quadros de referência 6, 7 e 8. Os trechos entre aspas (“") nos quadros são transcrições ipsis literis do relatório final da mesma.

69 Além das pesquisas referidas em nosso texto (e as demais que relacionamos na seção de referências bibliográficas), consideramos interessantes para complementação do tema desta tese os seguintes trabalhos: SOARES, Maria Salete Prado. Processos comunicacionais em espaços educativos: estudo de caso sobre linguagens não escolares ativando ecossistemas comunicativos no projeto Retratos do Butantã, mestrado, ECA/USP, 2004; ZEFERINO, Genésio. Educomunicação e sua Metodologia: Um estudo a partir de práticas de ONGs no Brasil, doutorado, ECA/USP, 2004; CARMO, Rita de Cássia Alves. Web cidadã: o mundo virtual como multiplicador de cidadania, monografia, ECA/USP, 2003; FREITAS, Helenice D'Assunção de. Educomunicação Aliada às práticas do Ensino a Distância, monografia, ECA/USP, 2003; ALVES, Patrícia Horta. Educomunicação: A experiência do Núcleo de Comunicação e Educação - ECA/USP. Mestrado, ECAUSP, 2002; BARI, Valeria Aparecida. Por uma epistemologia do campo da educomunicação: A inter-relação comunicação e educação pesquisada nos textos geradores do I congresso internacional sobre comunicação e educação, mestrado, ECA/USP, 2002; QUAIOTTI, Claudia Vanessa Sartori Telles de Souza. Gestão da Mediação Tecnológica: a busca de uma teoria para otimizar as relações comunicacionais no Colégio Sidarta, monografia, ECA/USP, 2002; QUADROS, Paulo da Silva. Cibernética Pedagógica na era das redes: ótica da educação digital na contemporaneidade, mestrado, ECA/USP, 2001 e ALVES, Hiliana Reis de Arruda. Ampliación de los procesos comunicativos en la enseñanza a distancia: análisis de tres modelos de tutoria, doutorado, Universidade Autonoma de Barcelona, 2000. Uma relação mais completa pode ser obtida no site do NCE-ECA/USP (http://www.usp.br/nce/). 


\section{PONTO SÍNTESE \\ 1 Presença de um "discurso futurista", que se refere a "transformações" e "mudanças" que incidem sobre a Comunicação e a Educação. \\ 2 Existência de um "esforço conjunto de algumas instâncias" em torno da questão Comunicação/Educação, a saber: (a) o Estado, (b) Agências Internacionais de fomento/financiamento às pesquisas/projetos; (c) 0 Meio Universitário e (d) a Sociedade Civil. \\ 3 "Diferentes graus de preocupação e abrangência" no interesse dos envolvidos com o tema pesquisado.}

4 "Pontos de vista distintos com relação ao foco da inter-relação em estudo", a saber, (a) Comunicação como instrumento e (b) Comunicação como objeto, abordados a partir de três vieses, preocupados, respectivamente com (I) a semiótica, (II) a linguagem e (III) o estudo das tecnologias.

5 Tendência ideológica conservadora de uma parcela dos envolvidos, que visam a um maior controle da Comunicação com base na área da "educação para os meios" (Media Education).

6 Presença marcante de dois outros campos de estudo social Antropologia e Sociologia - como fonte de aportes conceituais para a Educomunicação.

7 Reconhecimento da emergência do novo campo, no mais das vezes, por parte dos pós-graduandos, não obstante envolvimento de distintos segmentos sociais e profissionais nas ações educomunicativas pesquisadas.

8 Falta de pesquisas especulativas sobre o papel das diversas tecnologias e a relação da mídia com a estética.

9 Abordagem diferenciada dos especialistas de tradição latina - "iberoamericanos e francófonos" ("mais humanistas") - em relação aos anglófonos (mais centrada nas tecnologias).

10 Destaque para o uso de linguagens artísticas na Educomunicação.

11 Interesse no resgate das culturas negra e indígena.

12 Preocupação quase unânime com a delimitação e reconhecimento do novo campo.

quadro 6: síntese dos pontos sistematizados pela pesquisa perfil 
As conclusões parciais sistematizadas nos doze tópicos da pesquisa serviram de base para a definição de três hipóteses "históricas" da educomunicação (uma central e duas tributárias), as quais serviram de ponto de partida para o desenvolvimento de várias pesquisas posteriores - monografias, dissertações de mestrado e teses de doutoramento e marco de referência para o desenho dos vários projetos implementados ao longo dos últimos seis anos, que serão analisados ainda neste capítulo, pelo viés da significância em relação à MTE. O quadro 7 mostra a síntese das hipóteses:

\begin{tabular}{|ll|}
\hline \multicolumn{1}{|c|}{ HI PÓTESE } & \multicolumn{2}{c|}{ CONTEÚDO } \\
\hline $\begin{array}{l}\text { Central } \\
\text { (ou Primeira): }\end{array}$ & $\begin{array}{l}\text { "efetivamente já se formou, conquistou autonomia e encontra-se } \\
\text { em franco processo de consolidação um novo campo de } \\
\text { intervenção social a que denominamos de 'Inter-relação } \\
\text { Comunicação/ Educação'"; }\end{array}$ \\
\hline Segunda: & $\begin{array}{l}\text { "o novo campo, por sua natureza relacional, estrutura-se de um } \\
\text { modo processual, mediático, transdisciplinar e interdiscursivo, } \\
\text { sendo vivenciado na prática dos atores sociais através de áreas } \\
\text { concretas de intervenção social"; }\end{array}$ \\
\hline "reconhecemos, como possíveis materializações do campo, quatro \\
$\begin{array}{l}\text { áreas concretas de intervenção social (a) educação para a } \\
\text { comunicação, (b) mediação tecnológica na educação (c) } \\
\text { gestão comunicativa e (d) reflexão epistemológica." }\end{array}$
\end{tabular}

quadro 7: síntese das hipóteses declaradas na pesquisa perfil

A confirmação da hipótese central e seu desdobramento nas duas hipóteses tributárias forneceu, aos estudos educomunicativos, não só a espinha dorsal que sustenta suas diversas linhas de investigação, mas também um mapeamento detalhado das frentes de trabalho onde se verificavam, àquela altura, as atividades de intervenção social baseadas na inter-relação Comunicação-Educação.

Com base na Terceira Hipótese, destacamos aqui a importância dessas interfaces no estabelecimento das quatro Áreas de Intervenção ou Vertentes educomunicativas, sintetizadas no quadro 8: 


\begin{tabular}{|c|c|c|c|}
\hline $\begin{array}{l}\text { ÁREA DE } \\
\text { I NTERVENÇÃO }\end{array}$ & $\begin{array}{c}\text { OUTRAS } \\
\text { DENOMI NAÇÕES }\end{array}$ & CONCEITO & CARACTERÍSTICAS \\
\hline $\begin{array}{l}\text { Educação para a } \\
\text { Comunicação ( } 1 \underline{a} \text { ): }\end{array}$ & $\begin{array}{l}\text { - Media Literacy, } \\
\text { - Media } \\
\text { Education, } \\
\text { - Leitura Crítica } \\
\text { dos Meios; }\end{array}$ & $\begin{array}{l}\text { "promoção de ações } \\
\text { educativas frente à ação } \\
\text { e/ou ao impacto dos meios } \\
\text { de comunicação na } \\
\text { transformação da cultura ou } \\
\text { mesmo sobre o } \\
\text { comportamento dos } \\
\text { indivíduos"; }\end{array}$ & $\begin{array}{l}\text { cunho ideológico, } \\
\text { base teórica nos } \\
\text { "estudos de } \\
\text { recepção". }\end{array}$ \\
\hline $\begin{array}{l}\text { Mediação Tecnológica } \\
\text { na Educação ( } 2 \underline{a} \text { ): }\end{array}$ & $\begin{array}{l}\text { - Informática } \\
\text { Educativa, } \\
\text { - NTICs/TICs na } \\
\text { Educação; } \\
\text { - Educação } \\
\text { Tecnológica; - } \\
\text { Mediação } \\
\text { Pedagógica das } \\
\text { tecnologias }^{70} ;\end{array}$ & $\begin{array}{l}\text { estudo das mudanças } \\
\text { decorrentes da incidência de } \\
\text { inovações tecnológicas no } \\
\text { cotidiano das pessoas e } \\
\text { grupos sociais, assim como o } \\
\text { uso das ferramentas da } \\
\text { informação nos processos } \\
\text { educativos, sejam } \\
\text { presenciais, sejam a }^{\text {distância }}{ }^{71 ;}\end{array}$ & $\begin{array}{l}\text { evidenciada pela } \\
\text { rápida expansão de } \\
\text { sistemas } \\
\text { educativos } \\
\text { informatizados, } \\
\text { relacionada aos } \\
\text { conceitos de } \\
\text { Cibercultura (LÉVY, } \\
\text { 1999), linguagem } \\
\text { midiática, e } \\
\text { Sociedade em Rede } \\
\text { (CASTELLS, 1999). }\end{array}$ \\
\hline $\begin{array}{l}\text { Gestão da } \\
\text { Comunicação em } \\
\text { espaços educativos } \\
\left(3^{a} \text { ): }\right.\end{array}$ & $\begin{array}{l}\text { "ação } \\
\text { comunicativa; } \\
\text { apropriação e } \\
\text { manejo das } \\
\text { linguagens da } \\
\text { comunicação; } \\
\text { uso dos recursos } \\
\text { da informação } \\
\text { para a produção } \\
\text { cultural"; }\end{array}$ & $\begin{array}{l}\text { toda ação “voltada para o } \\
\text { planejamento, execução e } \\
\text { avaliação de planos, } \\
\text { programas e projetos de } \\
\text { intervenção social no espaço } \\
\text { da inter-relação } \\
\text { Comunicação/Cultura/Educaç } \\
\text { ão, criando ecossistemas } \\
\text { comunicativos”; }\end{array}$ & $\begin{array}{l}\text { produz-se em } \\
\text { ambientes } \\
\text { educativos formais } \\
\text { (escolares) e não } \\
\text { formais (ONGs, } \\
\text { emissoras, etc.); } \\
\text { busca a integração } \\
\text { prática entre as } \\
\text { várias vertentes } \\
\text { que aproximam a } \\
\text { Comunicação e a } \\
\text { Educação. }\end{array}$ \\
\hline $\begin{array}{l}\text { Reflexão } \\
\text { Epistemológica sobre } \\
\text { a I nter-relação } \\
\text { Comunicação/ } \\
\text { Educação (4ạ }) \text { : }\end{array}$ & Não constam; & $\begin{array}{l}\text { toda pesquisa voltada para } \\
\text { "o entendimento e a } \\
\text { legitimação do novo campo } \\
\text { quanto todos os programas } \\
\text { de investigação sobre cada } \\
\text { uma das vertentes que } \\
\text { compõem a inter-relação em } \\
\text { apreço"; }\end{array}$ & $\begin{array}{l}\text { “é, na verdade, a } \\
\text { reflexão } \\
\text { acadêmica, } \\
\text { metodologicamente } \\
\text { conduzida, que } \\
\text { garantirá unidade } \\
\text { às práticas da } \\
\text { Educomunicação, } \\
\text { permitindo que } \\
\text { evolua." }\end{array}$ \\
\hline
\end{tabular}

quadro 8: síntese das áreas de intervenção identificadas na pesquisa perfil

70 Essas denominações e as características apresentadas no quadro são contribuições de nossa pesquisa.
71 Cf. SOARES: $2002 \mathrm{a}, 18$. 
A essa definição inicial, agregou-se, posteriormente, uma quinta área de intervenção, denominada Área de Expressão Comunicativa através das artes. Esta última contribuição é fruto do trabalho de pesquisa da jornalista e professora Ângela Schaun junto aos movimentos e grupos de expressão afro-brasileira em Salvador, Bahia (SCHAUN, 2002).

É de se esperar que o acúmulo de pesquisas acadêmicas enfocando a Educomunicação resulte não só no delineamento mais claro das áreas de intervenção até aqui detectadas, mas também na identificação de novas vertentes desse campo emergente.

De nossa parte, reiteramos a expectativa de que esta tese contribua para aclarar as questões relativas à MTE, as quais serão, deste ponto em diante, examinadas de modo mais enfático. 


\subsubsection{A vertente educomunicativa da MTE}

A segunda área de intervenção ou modo de ação social educomunicativa detectada pela pesquisa perfil do NCE foi denominada "Mediação Tecnológica na Educação", expressão que, na apresentação das hipóteses, era sucintamente definida como um conjunto que compreendia "os procedimentos e as reflexões em torno da presença e dos múltiplos usos das tecnologias da informação na educação" (SOARES: 1999a, 29). Essa predefinição, considerada isoladamente, não oferece muitos elementos para interpretação, mas chama a atenção para dois aspectos: (1) a precedência dos procedimentos em relação às reflexões e (2) o uso da expressão tecnologias da informação (e não da comunicação).

Podemos entender sem dificuldade esse enunciado preliminar, se levarmos em conta que essa delimitação provisória parte dos aspectos mais evidentes do fenômeno da MTE, que subjazem no plano da constatação.

Na primeira vez em que o conceito é retrabalhado, surge uma gama muito maior de elementos passíveis de interpretação, para compreender como o nosso objeto de estudo se enquadrava, num primeiro momento, no quadro teórico educomunicativo em construção:

\footnotetext{
"Trata-se da área que vem ganhando grande exposição devido à rápida expansão dos sistemas de educação, tanto o presencial e quanto o a distância. Sabemos que os recursos tecnológicos clássicos como o rádio e a televisão tiveram dificuldade de ser absorvidos pelo campo da educação, especialmente por seu caráter lúdico e mercantil. Tal fato foi o principal responsável pela resistência dos educadores em dialogar com as tecnologias. O computador veio abalar essa dicotomia, pois possui em si mesmo os meios de produção de que o pequeno produtor cultural - o aluno e o professor - necessitam para seu trabalho diário. Devemos lembrar que a grande maioria dos sites são produzidos e dirigidos por centros de pesquisas científicas "(SOARES: 1999a, 30).
}

Tirante aspectos mencionados anteriormente em nosso texto, há que se destacar: a inclusão do rádio e televisão — que são tecnologias da comunicação, mais do que da informação — apontados como recursos tecnológicos;

(b) a constatação da dificuldade dos educadores no diálogo com essas tecnologias "clássicas", atribuída a seu caráter lúdico (recreativo, nãosério) e mercantil (direcionado por interesses comerciais); 
(c) a indicação de que o computador - tecnologia digital - representaria uma revolução tecnológica, principalmente pelo fato de subverter a lógica de produção e consumo da cultura no ambiente educacional;

(d) a equiparação do computador à Internet (a web como produção da tecnologia digital).

Essa definição ampliada de MTE da qual tratamos acrescenta ganhos inegáveis aos primeiros esforços para conceituar nosso objeto. Por outro lado, reflete também duas posições identificadas com a época em que foi emitida, as quais eram largamente aceitas, tanto na comunicação, quanto na educação:

(1) a descontinuidade evolutiva entre as tecnologias de informação/comunicação analógicas e as digitais;

(2) a indiferenciação, no âmbito das tecnologias digitais, entre a ferramenta ${ }^{72}$ comunicativa - computador - e o ambiente de interação comunicacional - a Internet.

Tais ponderações encontram eco em muitos textos clássicos de educadores que procuraram enquadrar as inovações tecnológicas a partir dos referenciais da Pedagogia.

O audiovisual libera e aumenta o campo do comportamento humano, mas como é com a informática? Esta questão liga-se diretamente ao futuro. Nos anos por vir, esta tecnologia vai realmente influir de maneira fundamental os feitos e os gestos do homem e da mulher e sua vida diária. (BABIN \& KOULOMDJAM: 1983, 138)

O desenvolvimento posterior das idéias sobre MTE, ainda dentro do relatório da pesquisa básica do NCE, contrapõe diversas linhas de argumentação que, partindo da concepção de "informática na educação", logo passam a destacar o papel do educador-

72 No sentido de que processa (produz, modifica, armazena, emite) a informação. 
mediador $^{73}$ — ou mais propriamente, o educomunicador — como elemento-chave para "resolver os desafios tradicionais da educação".

Poderíamos aqui nos estender na análise detalhada e crítica das idéias iniciais sobre MTE tal como se desenvolvem no relatório da pesquisa do NCE, ao qual nos referiremos sempre que necessário. Entretanto, consideramos mais interessante, por hora, nos ater a dois pontos nevrálgicos que pautarão nossa possível contribuição ${ }^{74}$.

O primeiro deles consiste na necessidade de estabelecermos uma linha de continuidade epistemológica que integre as tecnologias digitais às tecnologias analógicas. Dito de outra forma: entendemos como necessário analisar o "impacto"75 da informática como um continuum dentro da relação comunicação-educação, contextualizando-o numa mesma abordagem que comporte os meios impressos e audiovisuais e suas derivações tecnológicas aditivas (multimídia, hipermídia).

Partimos da constatação que, no período histórico compreendido entre o advento do microcomputador até a difusão comercial da Internet (e que corresponde, grosso modo, à década 1985-1995), ocorreu uma mudança decisiva no papel da informática: ela transferiu sua finalidade principal da manipulação de dados para a troca de informações em ambiente de rede. Vale dizer: ela deslocou seu foco do paradigma informacional para o comunicacional.

Isso não significa que, para nós, a informática não deva ser considerada um objeto de estudo válido e apreciável, principalmente do ponto de vista técnico ${ }^{76}$ ou tecnológico. A posição que sustentamos é a de que esse ponto de vista não oferece a suficiência e nem a dialogicidade necessárias para entender a MTE em seu aspecto de interface social dentro dos processos educomunicativos. Assim, trataremos os processos de MTE identificados nas expressões "Informática Educativa" e "TICs" pelo viés da análise crítica.

É preciso levar em conta o referencial freireano, quando ele ressalta que

\footnotetext{
73 A idéia e a expressão foram emprestadas de DIEUZEIDE (SOARES: 1999a, 44).

$74 \quad$ Vide capítulo introdutório.

75 Talvez a palavra não seja a mais feliz (daí as aspas) para descrever o fenômeno a que se refere. O problema é que ela remete a um choque ou "impressão ou efeito muito fortes deixados por certa ação ou acontecimento" (HOUAISS, 2007), ou seja, somos induzidos a enxergar num momento definido aquilo que é , na verdade, processo e resultado de um processo duradouro e complexo.

76 Informática (Informatics): ciência e estudo dos métodos e modos de processamento e transmissão da informação (COLLINS, 2001).
} 
“A compreensão crítica da tecnologia, da qual a educação de que precisamos deve estar infundida, é a que vê nela uma intervenção crescentemente sofisticada no mundo a ser necessariamente submetida a crivo político e ético. Quanto maior vem sendo a importância da tecnologia hoje, tanto mais se afirma a necessidade e rigorosa vigilância ética sobre ela" (FREIRE: 2000, 102).

Enquanto tarefa prática, essa abordagem implicará na aproximação conceitual entre "Meio" e "Mídia", o que, em nosso entendimento, é antes um resgate que uma construção.

O segundo (mas não menos importante) ponto destacado dentre as idéias constantes no relatório supracitado refere-se à importância com que enxergamos o agente do processo educomunicativo em nossa abordagem da MTE .

De fato, acreditamos que o mediador/educomunicador, mais do que qualquer outro elemento envolvido na mediação educomunicativa, é o fator decisivo para a realização da intencionalidade que esta última envolve.

Em apoio a essa convicção, escreve JACQUINOT 77 (1998, 01): "O que é um educomunicador? Não é um professor especializado encarregado do curso de educação para os meios. É um professor do século XXI, que integra os diferentes meios nas suas práticas pedagógicas."

No que tange à presente pesquisa, a centralidade do mediador será um dos pilares em que nos apoiaremos para construir nosso conceito educomunicativo de mediação. Essa é uma tarefa que envolve a identificação, a tipificação e o delineamento do perfil desse agente da mediação, o que faremos analisando seu papel no contexto dos diferentes projetos que constituem nossa amostragem (vide Introdução).

Para finalizar mais esta etapa em nossa discussão inicial, cabe apresentar o enunciado mais recente sobre o sentido da MTE, emitido, da parte do NCE, nas palavras de seu coordenador, o Prof. Dr. Ismar de Oliveira Soares:

"O capítulo mais em evidência no campo da educomunicação, neste momento, tanto nos Estados Unidos quanto na América Latina, é o que denominamos como mediação tecnológica na educação. Este campo de estudo contempla o estudo das mudanças decorrentes da incidência das inovações tecnológicas no cotidiano das pessoas e grupos sociais, assim como o uso das ferramentas da informação nos processos educativos, sejam presenciais, sejam a distância” SOARES (2002: 18).

77 Geneviève Jacquinot é professora da Universidade de Paris e Coordenadora de Comunicação do NCE-USP. 
Essa definição mais recente nos parece (1) mais concisa e clara em seu enunciado, (2) mais abrangente, expandindo o foco epistemológico para além do universo escolar e (3) reiterativa na atenção dirigida para a questão educação presencial versus educação a distância. Com certeza, essa menção já contempla o interesse do NCE pelos projetos de mediação baseados em Ambientes Virtuais de Aprendizagem (AVAs), com os quais o Núcleo vem desenvolvendo trabalhos desde o ano de 2002.

Essa última definição, ainda que provisória, será tomada como ponto de partida para nossas proposições, que terão lugar no final do capítulo II. Apresentaremos, na seqüência, um breve resumo dos projetos educomunicativos implementados pelo NCE de 2002 até hoje.

\subsection{Breve histórico analítico dos projetos do NCE}

Na década compreendida entre 1998 e 2008, na qual o NCE/USP se estrutura ${ }^{78}$, articula uma equipe qualificada e passa a gerir, sucessivamente (ou, o que é mais comum, concomitantemente) uma série de projetos de pesquisa e intervenção social, podemos relacionar alguns ganhos significativos para o entendimento da Educomunicação:

(a) o interesse de um grande número de pessoas - educadores efetivos, educomunicadores em potencial, educandos — é despertado e aglutina-se nos espaços onde transcorrem as ações educomunicativas;

(b) uma linha de práticas e procedimentos é estabelecida, pautada em dialogicidade, abordagem transdisciplinar, estratégias vivenciais de produção comunicativa e estímulo ao protagonismo dos participantes;

\footnotetext{
78 O surgimento do NCE-CCA-ECA/USP ocorre dois anos antes, quando "é oficialmente registrado em 04 de novembro de 1996, de acordo com as normas vigentes na Universidade de São Paulo, reunindo docentes, pesquisadores e estudantes de pós-graduação e graduação de várias instituições nacionais e internacionais, vinculados à reflexão e à prática que compreendem a inter-relação Comunicação/Educação" (ALVES: 2007, 02).
} 
(c) um grande volume de informações sobre as práticas educomunicativas passa a ser acumulado, na forma de registros audiovisuais (áudio, vídeo, fotos), relatórios de atividades e material didático, avulso ou compilado em cadernos de apoio;

(d) os pesquisadores associados ao NCE, graduandos e pós-graduandos, incrementam uma produção acadêmica considerável, que inclui as teses, dissertações, TCCs e textos avulsos apresentados e publicados em congressos e seminários nacionais e internacionais;

(e) o NCE organiza, ainda, certo número de encontros temáticos, em que as práticas educomunicativas são discutidas e disseminadas.

Tendo em vista o amplo entendimento e a adesão demonstrada por sua equipe de colaboradores ao referencial educomunicativo, a atuação preferencial do NCE na formação de formadores no âmbito das políticas públicas poderá confirmar-se como uma tendência marcante e crescente do novo campo. Não estamos falando numa compreensão unânime da praxis educomunicativa por parte de seus protagonistas, ainda mais porque estes compõem um grupo de profissionais/pesquisadores bastante heterogêneo quanto à formação (apesar da prevalência absoluta da área das Ciências Humanas). Entretanto, as contribuições esperadas de tantas e tão significativas ações, muito provavelmente, são (e continuarão sendo) devidas justamente à diversidade epistemológica representada no grupo.

Afinal, diálogo, polifonia, multivocidade, multiculturalidade e termos afins, soam quase como "palavras de ordem" na lógica educomunicativa. Na próxima seção, apresentaremos uma introdução resumida das ações educomunicativas envolvendo o NCE. 


\subsubsection{Educom.TV ${ }^{79}$}

O curso Educom.TV pode ser entendido como uma ação educomunicativa desenvolvida na modalidade EaD (educação à distância) e direcionada à formação de professores da rede pública do estado de São Paulo.

Ele foi o primeiro ${ }^{80}$ de uma série quase ininterrupta de projetos desenvolvidos em parceria entre o NCE e departamentos governamentais de gestão educativa, no caso, a Secretaria de Estado da Educação paulista (SEE-SP), com uma responsabilidade administrativa distribuída em múltiplas instâncias, tais como a Coordenadoria de Estudos e Normas Pedagógicas (CENP), responsável pela orientação institucional do projeto, e a GIP/DTE ${ }^{81}$, divisão da Fundação do Desenvolvimento Escolar (FDE), encarregada de coordenar o projeto.

O curso aconteceu no segundo semestre de 2002, e demandou o desenvolvimento de um Ambiente Virtual de Aprendizagem (AVA) interativo formatado especialmente para as necessidades do projeto.

A produção de conteúdos do curso, bem como a sua coordenação pedagógica, estiveram a cargo dos Professores Doutores Adilson Citelli, Ismar de Oliveira Soares (supervisor geral), Maria Cristina Castilho Costa e Marília Franco.

Os tópicos abordados no curso foram (1) O campo da Comunicação e suas áreas de intervenção; (2) Cultura, Consumo e Mídia; (3) Comunicação, Tecnologia da Informação e Educação; (4) Aprendendo com textos não escolares; (5) Características da Linguagem Audiovisual; (6) Teorias e práticas da recepção/TV; (7) Planejando a relação com a TV Aberta; (8) Planejando o uso do audiovisual na prática educativa; (9) Planejando a Educomunicação no plano pedagógico e (10) Avaliando o processo de ensino-aprendizagem.

79 As informações constantes neste tópico, em sua maior parte, foram extraídas do texto O Projeto Educom.TV: formação on-line de professores numa perspectiva educomunicativa, disponível no site do NCE (http://www.usp.br/nce/aeducomunicacao/saibamais/textos).

80 Se considerarmos o ciclo completo de implantação, do diagnóstico preliminar à avaliação.

81 Gerência de Informática Pedagógica do Departamento Técnico-Educacional. 


\begin{tabular}{|ll|}
\hline & \multicolumn{1}{c|}{ Educom.TV } \\
\hline $\begin{array}{l}\text { Entidades } \\
\text { promotoras: }\end{array}$ & SEE de SP (CENP, FDE)/ USP (NCE-ECA). \\
\hline Período de vigência: & Junho a dezembro de 2002. \\
\hline Demanda atendida: & 2.243 docentes da rede pública. \\
\hline Universo: & 1.034 unidades escolares de 88 DEs ${ }^{82}$ do estado de São Paulo. \\
\hline Modalidade: & $\begin{array}{l}\text { Curso de difusão cultural, não-presencial (EaD), estruturado } \\
\text { em atividades no ambiente interativo e 04 seminários } \\
\text { presenciais. }\end{array}$ \\
\hline $\begin{array}{l}\text { Estrutura do curso: } \\
\text { Dividido em } 10 \text { unidades temáticas, versando sobre conceitos, } \\
\text { pressupostos e metodologia de trabalho da educomunicação. } \\
\text { Organbiente comportou 35 salas virtuais tutoradas, cada uma } \\
\text { com 60 a 70 professores-cursistas. } \\
\text { envolvidas): }\end{array} \quad \begin{array}{l}\text { (I) Gestão SEE-SP (CENP/ FDE)/ Coordenação USP (NCE)/ } \\
\text { Administração do ambiente (empresa Real)/ Tutoria (NCE) -> } \\
\text { cursistas. }\end{array}$ \\
\hline $\begin{array}{l}\text { Papel do mediador } \\
\text { ("tutor"): }\end{array}$ & $\begin{array}{l}\text { (1) minimizar o desconforto docente frente ao ambiente } \\
\text { virtual; (2) orientar os cursistas no uso dos recursos do AVA; } \\
\text { (3) realizar o acompanhamento pedagógico dos conteúdos, } \\
\text { orientando e avaliando os cursistas. }\end{array}$ \\
\hline
\end{tabular}

quadro 9: síntese do projeto Educom.TV

Na questão específica da MTE, o Educom. $\boldsymbol{T} \boldsymbol{V}$ apresenta grande relevância por ser um projeto de formação docente, voltado para a rede pública e firmemente ancorado na sistemática dos cursos on-line. Mais que isso, a opção pela abordagem que não apartava, mas mesclava as tecnologias "novas" 83 e as formas de comunicação mais "conhecidas" com foco na televisão —, firmou-se como uma estratégia pedagógica educomunicativa empregada para trabalhar conteúdos de educomunicação ${ }^{84}$.

Os mediadores tiveram seu debut na função desdobrando-se para cumprir duas grandes tarefas: o domínio do ambiente virtual e de seus recursos e a mediação pedagógica ${ }^{85}$ dos conteúdos de comunicação dirigidos a professores-cursistas, muitos do quais travando contato pela primeira vez com aquela dinâmica de trabalho educativo.

\footnotetext{
82 Diretorias de Ensino, divisões regionais que reúnem grupos de municípios vizinhos, na administração da rede escolar estadual paulista.

83 Nossa crítica ao parâmetro de "novidade" nas tecnologias será mais bem fundamentada na análise das expressões que a MTE comporta, no capítulo IV.

84 Poderíamos talvez falar numa "metapedagogia" de base educomunicativa?

85 Esse conceito será desenvolvido mais à frente em nosso texto. Por hora, nos limitaremos a transcrever uma definição que aponta para "o tratamento de conteúdos e formas de expressão dos diferentes temas, a fim de tornar possível o ato educativo" (GUTIERREZ \& PRIETO: 1991, 08).
} 
A verificação dos resultados obtidos no Educom.TV, mais do que a concretização de trabalhos finais - projetos pedagógicos de viés educomunicativo elaborados pelos cursistas - , privilegiou um critério simples, mas que se constitui num ponto nevrálgico na avaliação de cursos on-line: a evasão. É nesse quesito que o projeto revela seu êxito mais evidente: ao final, o índice de concluintes ativos - a maior parte dos quais manifestou uma impressão positiva da formação — atingiu a margem de $91 \%{ }^{86}$.

Enquanto experiência educomunicativa em MTE, o êxito do Educom.TV demarcaria o crescimento de uma tendência cada vez mais acentuada de aproximação entre as demandas do sistema educativo e as soluções propostas pelos pressupostos teóricos da educomunicação tal como os evidenciamos no início deste subcapítulo. Pela significância do trabalho desenvolvido nesse primeiro projeto de grande fôlego, o NCE passou a contar com um juízo favorável enquanto parceiro do setor público na área educacional, o que fícou demonstrado na proposta que seria implementada na seqüência: o projeto Educom.rádio do município de São Paulo.

\subsubsection{Educom.rádio São Paulo}

O curso Educom.rádio, antes de ser abordado como uma política pública, garantida (ao menos "no papel”) por lei municipal em São Paulo ${ }^{87}$, representou um projeto de formação educativa, eminentemente presencial, vivenciado por professores, alunos e demais membros da comunidade escolar (pais, líderes comunitários, funcionários da educação), centrado no uso da linguagem e do formato radiofônicos.

De todos os projetos implementados em parceria entre o NCE e o poder público, o Educom.rádio foi, sem dúvida, o de maior dimensão. Isso pode ser afirmado tanto pelo número global de participantes envolvidos (ver quadro 10), quanto por seu alcance dentro de uma rede específica de espaços educativos, a qual, no caso, corresponde às unidades

86 Embora num sentido geral, que merece discussão posterior, podemos considerar que "a conclusão de um curso é considerada uma conquista. $\mathrm{O}$ abandono é encarado como um fracasso. Considera-se normalmente a taxa de conclusão ou abandono de um curso como a medida do sucesso dos sistemas de ensino a distância" (RUMBLE: 1993, 98).

87 Referimo-nos à Lei municipal 13.941/2004 de 28 de dezembro de 2004, que instituiu o "Programa Educom - Educomunicação pelas ondas do rádio", regulamentada pelo decreto 46211, de 15/08/2005. 
escolares de ensino fundamental da SME-SP ${ }^{88}$. Também foi o maior projeto educomunicativo do gênero em número de atividades: 1.008 encontros presenciais (cada um com duração de 08 horas), nos quais aconteceram 840 palestras, 420 workshops e 840 oficinas de produção ${ }^{89}$.

O diferencial mais significativo do Educom.rádio é o fato dele ter se originado de uma demanda por ações de prevenção à violência na escola, como relata o pesquisador Renato TAVARES (2007) em sua dissertação de mestrado:

\begin{abstract}
"Apesar de o "Projeto Vida" já possuir, naquela época, o status de "política pública" na administração municipal, o educom.rádio, no entanto, não era compreendido desta forma pelas autoridades. Tratava-se de um projeto "especial" encaixado no "Projeto Vida", entrando nas escolas pela via da política de prevenção da violência” (2007: 101).
\end{abstract}

O mesmo levantamento assinala a assimilação das práticas educomunicativas na estratégia global da prefeitura paulista, de forma que, "ao longo do $2^{\circ}$ semestre de 2004 , o projeto foi transferido para o DOT (Diretoria de Orientação Técnica), passando, pela primeira vez, a ser entendido como prática de interesse da área da 'educação formal'”.

A meta principal do projeto Educom.rádio era a de que todas as escolas de ensino fundamental deveriam receber o equipamento de produção radiofônica - uma aparelhagem compacta e portátil para a transmissão de rádio restrita - , fato que acabou não se verificando. Na prática, pouco mais de um terço das unidades escolares recebeu, efetivamente, o kit de produção. Assim, embora as metas de formação tivessem se cumprido, a implementação do projeto foi prejudicada em sua fase de conclusão, que coincidiu também com a sucessão municipal que alterou o jogo de forças no quadro político paulistano. A mudança da cor partidária, no final da gestão da prefeita Marta Suplicy, ocasionou a suspensão da quase totalidade dos projetos que se desenvolviam.

Até o momento, embora haja interesse e até algumas iniciativas incipientes de retomada do Educom.rádio, faltam indícios concretos de continuidade do projeto e do resgate de seu desenho original.

\footnotetext{
88 Secretaria Municipal de Educação de São Paulo.

89 O mapeamento, a análise conjuntural e a avaliação desse projeto, com base no registro da produção de peças radiofônicas educomunicativas nele desenvolvidas, constituem o tema da dissertação de mestrado de Renato Tavares Filho, a qual forneceu grande contribuição para esta tese.
} 
Sem nos estendermos, neste momento, na análise conjuntural das redes públicas, destacaremos alguns pontos sobre o papel da MTE no projeto Educom.rádio, o qual é bastante significativo:

(1) aparece a figura assumida do mediador - o educomunicador que atua diretamente com os grupos de trabalho;

(2) nesse modelo, o mediador acumula responsabilidades de natureza tecnológica (orientação instrumental), pedagógica (alfabetização midiática), logística (articulação interpessoal) e administrativa (relatoria, registro e controle de fluxo), o que o torna, de certa forma, o esteio do projeto;

(3) a tecnologia — ainda que relativamente conhecida (áudio analógico padrão $\mathrm{CD} / \mathrm{K} 7)$ - passa a ocupar um lugar central entre as preocupações da escola, seja por sua presença (o equipamento "complicado", que intimida), ou por sua ausência (o equipamento que não foi entregue, "inviabilizando o projeto" 90 ).

Podemos dizer que o projeto Educom.rádio, mesmo afetado pela descontinuidade enquanto proposta junto à administração municipal, consolidou um modelo de trabalho que vinha sendo gestado pelo NCE e estabeleceu parâmetros para os projetos educomunicativos que o seguiriam. Um bom exemplo dessa afirmação foi a transposição de princípios e métodos do Educom.rádio São Paulo para o projeto Educom.rádio Centro-Oeste, que será abordado na seqüência.

Para concluir este tópico, achamos oportuno considerar que, no quadro das tecnologias de uso corrente nos espaços educativos, não estabelecemos distinções epistemológicas embasadas no nível técnico ou na sofisticação dos materiais. Assim, para nós, a tecnologia analógica empregada nos projetos "tipo educom" é analisada a partir dos mesmos parâmetros de MTE que nos apoiarão para a análise dos projetos mediados com o uso de ambientes virtuais e recursos digitais. 


\begin{tabular}{|c|c|}
\hline \multicolumn{2}{|r|}{ Educom.rádio São Paulo } \\
\hline $\begin{array}{l}\text { Entidades } \\
\text { promotoras: }\end{array}$ & $\begin{array}{l}\text { SME de São Paulo (Diretoria de Projetos Especiais, } \\
\text { posteriormente, DOT)/USP (NCE). }\end{array}$ \\
\hline $\begin{array}{l}\text { Período } \\
\text { vigência: }\end{array}$ & Agosto/2001 a dezembro/2004. \\
\hline Demanda atendida: & $\begin{array}{l}8.636 \text { cursistas }(100 \%) \text {, sendo: (1) } 5.200 \text { professores e } \\
\text { funcionários }(60,2 \%),(2) 2.861 \text { estudantes }(33,1 \%) \text { e (3) } \\
575 \text { membros da comunidade }(6,6 \%) \text {. }\end{array}$ \\
\hline Universo: & 455 escolas de ensino fundamental da cidade de São Paulo. \\
\hline Modalidade: & $\begin{array}{l}\text { Curso de difusão cultural, presencial, baseado em palestras e } \\
\text { atividades de produção radiofônica. }\end{array}$ \\
\hline Estrutura do curso: & $\begin{array}{l}\text { Doze encontros presenciais de oito horas (total: } 96 \text { horas), } \\
\text { divididos em três módulos ( } 04 \text { encontros cada). }\end{array}$ \\
\hline $\begin{array}{l}\text { Organograma } \\
\text { (funções } \\
\text { envolvidas): }\end{array}$ & $\begin{array}{lccc}\text { Gestão: } & \text { DPE-DOT } & \text { (SME-SP)/Coordenação USP (NCE)/Apoio } \\
\text { Técnico } & \mathrm{NAE}^{91} \mathrm{~S} \text { (PMSP) Articuladores/Assistentes de } \\
\text { Articulação/Mediadores (NCE) } \rightarrow \text { cursistas (alunos, } \\
\text { professores, comunidade escolar). }\end{array}$ \\
\hline Papel do mediador & $\begin{array}{l}\text { (1) desenvolver atividades teóricas e práticas com os } \\
\text { cursistas; ( } 2 \text { ) mediar a produção radiofônica dos alunos; ( } 3 \text { ) } \\
\text { coordenar e integrar as ações dirigidas aos professores com } \\
\text { os demais participantes. }\end{array}$ \\
\hline
\end{tabular}

quadro 10: síntese do projeto Educom.rádio

\subsubsection{Educom.rádio Centro-Oeste}

O projeto denominado "Educomunicação pelo rádio em escolas de ensino médio da região Centro-Oeste" ou, simplesmente, Educom.rádio Centro-Oeste, serviu como prova inconteste da possibilidade de expansão dos pressupostos educomunicativos (MTE, inclusive) para uma realidade totalmente distinta daquela que abrigou o Educom.rádio em São Paulo. Ainda que mal comparando, podemos ilustrar, num quadro, as diferentes condições prévias entre um e outro projeto:

\footnotetext{
91 Núcleos de Ação Educativa, divisões administrativas da SME-SP que substituíram as "Delegacias de Ensino". Agrupamentos de distritos e bairros em 13 divisões, a partir de 2002, por conta da reforma administrativa das subprefeituras, elas foram re-estruturadas em 31 Coordenadorias de Educação. A referência aos "NAEs" foi, em decorrência, substituída pela referência às Coordenadorias, nas fases finais do projeto.
} 


\begin{tabular}{|ll|}
\hline Educom.rádio São Paulo & Educom.rádio Centro-Oeste \\
\hline Gestão Municipal: SME-SP (DPE/ DOT); & Gestão Federal: MEC (SEED/SEMT) ${ }^{92} ;$ \\
\hline Modalidade semipresencial; & Modalidade presencial; \\
\hline Nível: Ensino Fundamental & Nível: Ensino Médio \\
\hline $\begin{array}{l}\text { Implementado em escolas urbanas do } \\
\text { município de São Paulo; }\end{array}$ & $\begin{array}{l}\text { Implementado em escolas urbanas, } \\
\text { rurais, indígenas e quilombolas; }\end{array}$ \\
\hline $\begin{array}{l}\text { Concentrado na região metropolitana de } \\
\text { São Paulo. }\end{array}$ & $\begin{array}{l}\text { Espalhado por três estados: Mato Grosso, } \\
\text { Mato Grosso do Sul e Goiás. }\end{array}$ \\
\hline
\end{tabular}

quadro 11: condições diferenciadas dos projetos Educom.rádio São Paulo e Centro-Oeste

Com vários pontos "herdados" também da metodologia do $\boldsymbol{E d u c o m . T V}$, o curso do Centro-Oeste utilizou um Ambiente Virtual de Aprendizagem e salas virtuais. Nesse AVA, foram disponibilizados os conteúdos

(1) Educomunicação e suas linguagens;

(2) Pedagogia da linguagem radiofônica;

(3) planejamento de educomunicação em espaços educativos e

(4) projetos de educomunicação com o uso da linguagem radiofônica.

A metodologia adotada baseou-se na leitura de três níveis de textos motivadores, de aprofundamento e complementares - e na resolução de exercícios no ambiente virtual. Dessa forma, a MTE foi desenvolvida por meio de ferramentas analógicas e também digitais - com ênfase destas últimas numa escala muito maior que no Educom.rádio de São Paulo.

Os encontros presenciais constituíam-se em momentos para orientações gerais e esclarecimento de dúvidas dos cursistas e, também, para verificação dos resultados alcançados pela estratégia didática semipresencial e para a constituição do que hoje em dia chamaríamos de uma "comunidade virtual" $"$.

92 As siglas significam, respectivamente, Ministério da Educação, Secretaria de Educação a Distância e Secretaria de Educação Média e Tecnológica.

93 Sobre estas poderíamos dizer que "se constituem de pessoas com escalas de valores comuns, interesses comuns, autonomia e relações democráticas. São sustentadas pela força da coletividade a partir de sua própria construção coletiva, da sua constituição autopoiética, as suas relações sociais e transversais. São representações, engrenagens, microcosmos, componentes da engenharia do laço social; elas podem promover a formação de inteligências coletivas" (TAJRA: 2002, 34). 
Podemos assinalar, a respeito disso, como a trajetória dos projetos educomunicativos do NCE caminhou no sentido de envolver setores mais amplos e diversos ligados à educação. Embora, nesta pesquisa e na maioria dos trabalhos baseados em relatos de projetos do NCE, o aspecto "formação de formadores" ganhe bastante destaque, identificamos um viés na praxis educomunicativa que estende o protagonismo da ação educativa para além da figura do professor.

Essa reflexão nos ajudará a entender a importância do projeto Educom.geração cidadã e, mais à frente, nossa própria reconstrução do papel do mediador.

\begin{tabular}{|ll|}
\hline \multicolumn{3}{|l|}{$\begin{array}{l}\text { Educom.rádio Centro-Oeste } \\
\text { promotoras: }\end{array}$} & $\begin{array}{l}\text { MEC (SEED e SEMT)/Secretarias de Estado da Educação } \\
\text { de MT, MS e GO/USP (NCE). }\end{array}$ \\
\hline Período de vigência: & Outubro de 2003 a outubro de 2004. \\
\hline Demanda atendida: & $\begin{array}{l}140 \text { educadores acompanhados de 20 especialistas das } \\
\text { respectivas secretarias de educação. }\end{array}$ \\
\hline Universo: & $\begin{array}{l}70 \text { escolas urbanas, rurais, indígenas e quilombolas dos } \\
\text { estados da região Centro-Oeste. }\end{array}$ \\
\hline Modalidade: & $\begin{array}{l}\text { Curso de aperfeiçoamento, semipresencial e teórico- } \\
\text { prático. }\end{array}$ \\
\hline Estrutura do curso: & $\begin{array}{l}\text { Dividido em quatro tópicos temáticos, disponibilizados on- } \\
\text { line }{ }^{94} \text {, com duração estimada de 180 horas (docentes) 264 } \\
\text { horas (técnicos). }\end{array}$ \\
\hline $\begin{array}{l}\text { Organograma } \\
\text { (funções envolvidas): }\end{array}$ & $\begin{array}{l}\text { Gestão: MEC (SEED/SMT)/ SEE-MT, SEE-MS, SEE-GO/ } \\
\text { USP (NCE)/Tutores e Mediadores (NCE) -> Cursistas. }\end{array}$ \\
\hline $\begin{array}{l}\text { Papel do mediador } \\
\text { (“tutor"): }\end{array}$ & $\begin{array}{l}\text { (1) apresentar os recursos do ambiente virtual e orientar } \\
\text { os cursistas; (2) contextualizar o uso da linguagem } \\
\text { radiofônica em sala de aula; (3) construir uma } \\
\text { “comunidade virtual” de cursistas no decorrer do projeto. }\end{array}$ \\
\hline
\end{tabular}

quadro 12: síntese do projeto Educom.rádio Centro-Oeste

\subsubsection{Educom.Geração Cidadã}

O curso Educom.Geração Cidadã foi desenvolvido pelo NCE e pelo Consórcio da Juventude, uma parceria entre as prefeituras de seis municípios da Grande São Paulo ${ }^{95}$ criada especialmente para viabilizar a proposta de trabalho do Programa Primeiro

\footnotetext{
94 Como nem todos os cursistas do Centro-Oeste dispunham de acesso à web, os conteúdos também foram disponibilizados em formato impresso.

95 A saber: Embu das Artes, Embu-Guaçu, Itapecerica da Serra, Juquitiba, São Lourenço da Serra e Taboão da Serra.
} 
Emprego (do Ministério do Trabalho) voltada para a capacitação profissional de jovens egressos do ensino médio. Os encontros, com cerca de três horas de duração cada, aconteciam três vezes por semana, no espaço cedido por uma escola particular do município de Embu. O curso foi oferecido nos períodos matutino, vespertino e noturno, e o público atendido, estimado em cerca de dois mil jovens com idade entre 15 e 18 anos.

Esse diferencial administrativo adquire relevância quando pensamos no nível de negociação política necessário à sustentação de uma iniciativa dessa natureza e magnitude. É preciso lembrar que, até então, o compartilhamento na gestão dos projetos do NCE acarretava parcerias institucionais bem delimitadas quanto às atribuições específicas das partes envolvidas. Esse panorama revelou-se bastante diferente no Educom.Geração Cidadã, o que se justifica — ao menos em parte — pela necessidade de se "costurar alianças" entre governos municipais de cor partidária diferenciada e entendimento diverso sobre o foco do projeto e a responsabilidade das tarefas a serem executadas.

As principais atividades desenvolvidas durante os três meses e meio de duração do projeto foram:

(1) palestras temáticas (workshops), cujos temas foram cuidadosamente relacionados com o exercício da cidadania e o respeito à diversidade cultural, servindo como base para a apropriação crítica de conceitos e atitudes de engajamento social;

(2) oficinas de linguagem radiofônica, desenvolvidas sob a perspectiva de promover a oralidade, a comunicação interpessoal e o domínio das tecnologias de produção em mídias sonoras;

(3) oficinas de Internet e construção de blogs, orientadas para desenvolver o domínio da linguagem escrita e a inclusão digital por meio do acesso à web. Essa atividade resultou, ao final, na publicação de mais de uma centena de blogs ${ }^{96}$. 
Um aspecto particularmente interessante de nossa participação no projeto aqui relatado reflete-se no vínculo direto entre educador e educando, estabelecido como condição sine qua non para a construção do ecossistema educomunicativo.

As condições ambientais desafiadoras - espaço inadequado ${ }^{97}$, dificuldades administrativas, heterogeneidade do grupo - , longe de inviabilizar o trabalho, ofereceram uma oportunidade única para entender as potencialidades e limitações da MTE numa situação pedagógica muito próxima daquela encontrada na escola pública.

Embora as condições de trabalho tenham melhorado sensivelmente no decorrer do projeto, não se pode negar que influíram bastante, acarretando um desgaste sensível, físico e mental, no grupo de mediadores.

\begin{tabular}{|ll|}
\hline \multicolumn{4}{|c|}{ EDUCOM.GERAÇÃO CI DADÃ } \\
\hline $\begin{array}{l}\text { Entidades } \\
\text { promotoras: }\end{array}$ & $\begin{array}{l}\text { Projeto Primeiro Emprego (Ministério do Trabalho)/ } \\
\text { Consórcio da Juventude (06 municípios)/ASMOREJ I } \\
\text { (NCE-ECA). } / \text { USP }\end{array}$ \\
\hline Período de vigência: & $02 / 01 / 2006$ a 25/03/2006. \\
\hline Demanda atendida: & 2.000 cursistas (número aproximado). \\
\hline Universo: & $\begin{array}{l}\text { Jovens recém-egressos do Ensino Médio selecionados pelos } \\
\text { representantes municipais. }\end{array}$ \\
\hline Modalidade: & $\begin{array}{l}\text { Curso presencial semiprofissionalizante com interação online } \\
\text { (publicação de atividades). }\end{array}$ \\
\hline Estrutura do curso: & $\begin{array}{l}\text { Curso dividido tematicamente em dez unidades, versando } \\
\text { sobre conceitos, pressupostos e metodologia de trabalho da } \\
\text { educomunicação. }\end{array}$ \\
\hline Organograma: & $\begin{array}{l}\text { Gestão (ASMOREJI)/Coordenação de mediadores/ } \\
\text { Mediadores -> cursistas. }\end{array}$ \\
\hline $\begin{array}{l}\text { Papel do mediador } \\
\text { ( “tutor”): }\end{array}$ & $\begin{array}{l}\text { (1) constituir grupos de trabalho integrado; (2) introduzir e } \\
\text { orientar os cursistas no uso do equipamento; (3) realizar o } \\
\text { acompanhamento pedagógico dos conteúdos. }\end{array}$ \\
\hline
\end{tabular}

quadro 13: síntese do projeto Educom.Geração Cidadã

\footnotetext{
$97 \quad$ Além da falta e do subdimensionamento de recursos tecnológicos, mais do que em outros projetos (fato constatado in loco e registrado nos relatórios dos mediadores que atuaram no Educom.Geração Cidadã), o ambiente em si não contava com o pré-requisito básico de um isolamento termoacústico satisfatório.

98 Associação de Moradores da Região do Jardim Independência, corresponde a uma organização civil sem fins lucrativos que atua no município que sediou o projeto e na região adjacente.
} 


\subsubsection{Outros projetos}

Além dos projetos de grande dimensão relatados ao longo do presente capítulo, o NCE, sem abrir mão de sua orientação epistemológica, envolveu-se em uma série de projetos de menor âmbito, voltados para o atendimento de demandas educativas junto ao terceiro setor e ao setor privado. Faremos uma alusão sucinta a cada uma destas iniciativas.

\subsubsection{Educom.Saúde}

O Educom.Saúde foi outro projeto educomunicativo do NCE de âmbito municipal, dessa vez desenvolvido em parceria com a Secretaria Municipal de Saúde. Pode ser resumido como um curso de formação de gestores em educomunicação em saúde, o que o aproxima mais da área de intervenção conhecida como educação para a comunicação.

Sua duração foi de pouco mais de três meses e cinqüenta gestores participaram do

processo formativo ${ }^{99}$ que enfocou: (1) interlocução entre promotores e usuários dos serviços de saúde, (2) relacionamento com as mídias, (3) produção midiática e (4) projetos de difusão (ALVES, 2002).

A metodologia básica que orientou o projeto Educom.rádio serviu como suporte para articular o educom.saúde, no que se refere à divisão dos cursistas em núcleos formativos (macro-regiões), ao caráter vivencial do estudo das mídias (prática de produção) e à avaliação baseada no cumprimento da tarefa de planejar projetos-piloto a serem implementados no ano seguinte. De forma semelhante ao Educom.rádio, o Educom.saúde foi descontinuado após a sucessão municipal paulistana de 2004-2005.

Apesar de sua não-continuidade e da falta de uma avaliação mais profunda sobre os resultados alcançados, consideramos o Educom.saúde como uma iniciativa merecedora de um estudo minucioso, uma vez que a interface inovadora Comunicação-Educação-Saúde é uma vertente ainda pouco explorada pelos projetos de intervenção comunicativos e educomunicativos junto ao poder público.

99 Funcionários do Sistema Municipal de Vigilância em Saúde (SMVS). 
Além disso, pela falta de elementos documentais ou de um enfoque mais centrado na abordagem tecnológica a mediação, esse projeto não será referenciado com maior atenção no presente estudo.

\subsubsection{Tô de olho.TV}

Esse projeto pode ser considerado um desdobramento direto do Educom.TV, configurando-se na disponibilização de um espaço virtual interativo - o site http://www.usp.br/todeolho - para alunos de escolas de ensino fundamental e médio, e também professores da rede pública estadual.

O site disponibilizava sete seções interativas, assim denominadas: (1) Inscreva-se, (2) Quadro a Quadro, (3) Bate-Boca, (4) Cenas em Trânsito, (5) Encontro Marcado, (6) Blog com Tânia e (7) Oficina da Palavra.

Os participantes poderiam publicar suas opiniões de maneira síncrona (chats) ou assíncrona (fóruns), acessar conteúdos postados e ainda realizar atividades propostas por um moderador (ALVES, 2002).

O assunto do site, como não poderia deixar de ser, era a televisão e suas produções, que serviam como ponto de partida para debates e discussões. Embora ainda esteja disponível on-line, as últimas contribuições registradas no site datam de 2004.

Embora se constitua num caso claro de MTE, vale o comentário do subitem anterior, o que nos leva a considerar essa iniciativa como meritória de uma pesquisa mais acurada.

\subsubsection{Educom .CSL (Colégio São Luís)}

Um dos colégios privados mais tradicionais da capital paulistana, fundado por padres jesuítas ainda no século XIX, o Colégio São Luís abriu a seus alunos e professores a possibilidade de trabalho com a linguagem radiofônica. $\mathrm{O}$ formato escolhido para encampar essa atividade foi a montagem de uma rádio interna, definida pela legislação como rádio restrita $^{100}$, cuja implantação contou com a assessoria pedagógica e tecnológica do NCE.

$100 \quad$ Ver lei no 9.612 , de 9/02/1998. 
A formação básica — cujos temas foram trabalhados a partir de uma ótica educomunicacional - teve lugar no ano de 2006, e dela participaram alunos, desde a sétima série do ensino fundamental até a terceira série do ensino médio, assim como professores que aderiram voluntariamente à proposta. Segundo as informações constantes no site da instituição:

"Em 2007, a Rádio é utilizada pelos alunos do Projeto Imprensa, que realizam a cobertura de eventos do CSL e produzem programas jornalísticos e de entretenimento para os demais alunos (...). Na realização de eventos internos, a Rádio São Luís é utilizada pelo grupo do Grêmio Estudantil, que entrevista os participantes, diverte o público e toca músicas" (http://www.saoluis.org/projetos/radio-sao-luis).

A experiência educomunicativa da Rádio São Luís propiciou uma oportunidade para que o NCE testasse os pressupostos educomunicativos dentro de um universo nitidamente distinto daquele em que realizara a maioria de seus projetos (setor público). A boa aceitação da proposta — que ainda carece de uma avaliação mais sistematizada pode ajudar a expandir o campo de atuação profissional dos educomunicadores ${ }^{101}$.

\subsubsection{Educom.Fundhas}

A Fundação Hélio Augusto de Souza - FUNDHAS, atuante desde 1997, pode ser descrita como:

\footnotetext{
“o maior projeto social de São José dos Campos na atualidade. A partir de 2001, passou a atender mais de quatro mil crianças e adolescentes, dos 7 aos 18 anos, de famílias que possuem baixo nível de escolaridade e sócio-econômico, residem nas periferias e em condições precárias" (TAJRA: 2002, 71).
}

Entre os objetivos prioritários declarados da entidade estão: (1) garantia de serviços sociais básicos (educação, alimentação, saúde e transporte), (2) orientação pedagógica e (3) encaminhamento profissional. No ano de 1998, com o desenho de seus primeiros projetos de inclusão digital, a FUNDHAS iniciou um trabalho na área de MTE, com ênfase no uso de computadores e, um pouco depois, da Internet.

\footnotetext{
101 Embora, em nossa opinião, ainda seja prematuro estabelecer um vínculo entre esse campo emergente e o mercado de trabalho.
} 
É interessante notar que, nessa fase inicial de implantação das tecnologias digitais, a fundação recebeu apoio logístico, técnico e pedagógico da Kidlink, uma organização multinacional sediada na Noruega, cuja especialidade é assessorar a implantação de redes educacionais de computadores e oferecer conteúdo educativo on-line.

As atividades do Educom.fundhas tiveram início em agosto de 2006 com a promoção de um seminário dirigido, prioritariamente, aos jovens adolescentes atendidos pela fundação. $\mathrm{O}$ evento em si já constituiu um exercício prático do modus operandi da educomunicação, uma vez que a condução, relatoria e encaminhamento ficaram sob a responsabilidade dos próprios estudantes.

No ano seguinte, três das vinte e três unidades da fundação ganharam a infraestrutura (espaço, equipamento, formação) de uma rádio educativa, registrando uma produção crescente de programas criados e realizados pelos jovens.

O Educom.fundhas é um projeto em franco desenvolvimento, o que implica em muitas perspectivas - e expectativas - quanto ao seu desenrolar. A natureza nãogovernamental da mantenedora (associação filantrópica) indica uma vertente possível de incremento das políticas públicas sem a intervenção direta do Estado.

Uma questão que deve surgir, mais cedo ou mais tarde, é a aproximação necessária entre os projetos educomunicativos que usam o rádio e a base já instalada de tecnologias digitais gerida pela instituição. Caso o investimento nos princípios norteadores da educomunicação se consolide, conforme é esperado, é bem provável que essas duas frentes de trabalho venham a se unificar.

$\mathrm{O}$ que se afirmou a respeito dos projetos anteriores e, de forma ainda mais justificada, neste último caso, é a centralidade assumida pela questão da MTE nas parcerias educomunicativas do NCE.

Assim, propositalmente, omitimos desta apresentação sintética (representada esquematicamente no quadro 14), o curso on-line "Formação Continuada em Mídias na Educação" ${ }^{102}$, o qual representa, sem dúvida, a experiência mais relevante do NCE no que toca à MTE ${ }^{103}$.

\footnotetext{
102 Ver quadro 03 na Introdução desta tese.

103 Esta afirmação é válida para o momento histórico no qual se escreve esta tese: a demanda crescente por educação a distância (ou educação virtual interativa, como preferem alguns) tende mudar esse panorama em pouco tempo.
} 
Acreditamos, até este ponto, ter oferecido ao leitor uma boa noção dos conceitos e da história da práxis educomunicativa, de modo a deixar o mínimo possível de dúvidas sobre (1) nossos pressupostos epistemológicos; (2) a terminologia que usaremos em nossa análise $^{104}$ e (3) nossos objetivos quanto à finalidade da presente pesquisa.

Dedicaremos o próximo capítulo à exposição do cerne de nossa problemática.

\begin{tabular}{|c|c|c|c|c|}
\hline & Educom.saúde & TÔdeOLHO.TV & Educom.CSL & Educom.FUNDHAS \\
\hline $\begin{array}{l}\text { Entidades } \\
\text { parceiras: }\end{array}$ & $\begin{array}{l}\text { SMS-SP }\left(\text { CVS }^{105}\right) \mathrm{e} \\
\text { FUSP }^{106}(\mathrm{NCE}) .\end{array}$ & SEE-SP e NCE. & $\begin{array}{l}\text { Colégio São Luiz e } \\
\text { NCE. }\end{array}$ & $\begin{array}{l}\text { Fundação Hélio } \\
\text { Augusto de Souza e } \\
\text { NCE. }\end{array}$ \\
\hline Período: & $\begin{array}{l}\text { Setembro a } \\
\text { dezembro de } 2004 .\end{array}$ & $2002-2003$ & $2006-2007$. & $2006-2008$. \\
\hline $\begin{array}{l}\text { Demanda } \\
\text { atendida: }\end{array}$ & $\begin{array}{l}50 \text { profissionais de } \\
\text { vigilância sanitária } \\
\text { municipal de São } \\
\text { Paulo. }\end{array}$ & $\begin{array}{l}\text { Alunos e } \\
\text { professores de } \\
\text { cerca de } 80 \\
\text { escolas estaduais } \\
\text { de São Paulo }{ }^{107} \text {. }\end{array}$ & $\begin{array}{l}\text { Alunos e } \\
\text { professores do } \\
\text { ensino médio e } \\
\text { fundamental do } \\
\text { CSL. }\end{array}$ & $\begin{array}{l}\text { Adolescentes e } \\
\text { educadores } \\
\text { vinculados à } \\
\text { Fundação. }\end{array}$ \\
\hline Natureza: & interação presencial & interação on-line & interação presencial & interação presencial \\
\hline Estrutura: & $\begin{array}{l}\text { Curso com } 10 \\
\text { encontros semanais } \\
\text { temáticos de } 08 \\
\text { horas cada. }\end{array}$ & $\begin{array}{l}\text { Site interativo } \\
\text { disponibilizado. }\end{array}$ & $\begin{array}{l}\text { Palestras e } \\
\text { workshops } \\
\text { temáticos sobre } \\
\text { educomunicação. }\end{array}$ & $\begin{array}{l}\text { Seminários (dois) e } \\
\text { oficinas periódicas. }\end{array}$ \\
\hline
\end{tabular}

quadro 14: síntese geral dos demais projetos coordenados pelo NCE

104 Eventualmente, novos esclarecimentos serão agregados na medida em que os considerarmos necessários.

105 Coordenadoria de Vigilância Sanitária da Secretaria Municipal de Saúde de São Paulo.

106 Fundação de apoio à Universidade de São Paulo.

107 Observou-se a inclusão, também, de algumas escolas privadas e de pelo menos três unidades do CEFAM (Centro Específico de Formação e Aperfeiçoamento do Magistério), programa de formação técnica de professores desativado em 2005. 


\section{CAPÍTULO II}

\section{MTE: A CONSTRUÇÃO DE UM SENTIDO}




\title{
2.1 PARA QUE SERVE "FIXAR UM SENTIDO"?
}

\begin{abstract}
Somos o rio de Heráclito, para quem o homem de ontem não é o homem de hoje e o de hoje não será o de amanhã. Nós mudamos incessantemente. Mas se pode afirmar também que a releitura de um livro e cada lembrança dessa releitura renovam o texto. Porque também o texto é o rio imutável de Heráclito. (J.L.Borges)
\end{abstract}

Antes mesmo que definíssemos a MTE como nosso objeto de estudo e assumirmos a proposição de aclarar seu sentido e significado ${ }^{108}$, houve um momento de hesitação sobre onde, ou em que ponto, começa a necessidade de buscar tal definição.

Afinal, quando falamos em "mediação", temos uma idéia razoavelmente clara do que ela trata. Ou não? Analisemos a seguinte sentença como uma resposta a essa pergunta:

\begin{abstract}
“Uma epistemologia 'responsável' poria em relevo que a mediação é um conceito chave tanto no campo do pensamento como na praxis. Mas, a mediação é a grande ausente das preocupações teóricas, talvez porque sua qualidade de "teto' ${ }^{109}$ de todo conhecimento desanima os investigadores." (SANTOS: 1988, $595^{110}$ )
\end{abstract}

Assim, parece haver uma diferença substancial entre (a) o emprego de um termo "consensual" e (b) a exposição de um conceito estabelecido - embora ambos pareçam diferentes maneiras de se reafirmar o óbvio. Enquanto, no primeiro caso, ficamos na explanação algo inútil e redundante, no segundo, abre-se a possibilidade de reavaliar criticamente nossa "verdade" tão historicamente construída quanto qualquer outra.

Na realidade, buscar a reafirmação do óbvio pode levar a um resultado diverso, sendo uma instigante oportunidade para questionar a robustez de alguns axiomas. Tal procedimento crítico não é desconhecido, também, no campo da educação, e tem se manifestado, em abordagens recentes, por meio de expressões como "ressignificar" ou "lançar um novo olhar sobre" algum elemento da praxis instituída na educação.

Em síntese, decidimos reiniciar nossa reconstrução teórica desde o componente mais geral sobre o qual se assenta o conceito da MTE: a própria mediação.

\footnotetext{
108 A esse respeito, ver quadro 1 e respectiva nota de rodapé em nossa Introdução.

109 No sentido de "abrigo", mas respeitando a amplitude do espanhol techo.

110 A tradução é nossa, a partir do original em espanhol.
} 
Assim, parece-nos notável, como no campo da comunicação, tem sido muito comum que se fale em "mediação", "mediar", "mediatização" e vocábulos similares que compartilham o radical etimológico (mas não necessariamente o mesmo sentido), sem uma preocupação maior com a definição expressa de seu conceito. ${ }^{11}$

Queremos deixar claro, neste prolegômeno, que abrir mão do caráter “tácito" do qual a mencionada expressão se reveste, amiúde, é condição básica para compreender nosso objeto de estudo "Mediação Tecnológica" e seu recorte "MT na Educação".

Nosso primeiro questionamento declarado nesse sentido é:

Se a mediação é um termo tão corrente nos estudos da comunicação - e também da educação - por que, tão freqüentemente, lhe faltam clareza (ausência de ambigüidade) e consistência (ausência de contradição) em seu emprego?

Tomemos esse exemplo, selecionado sem outra preocupação que não a de exemplificar o que chamamos de falta de clareza: "Desse modo, refletir sobre a problemática da comunicação enquanto mediação educacional na era da informação implica"112. Mesmo citada fora do contexto, a frase nos leva a questionar:

- A comunicação pode ser considerada uma mediação?

- Como categorizar uma mediação educacional?

- Que elementos perfazem este modelo de mediação (Quem medeia? Quem é mediado?)

Em relação à falta de consistência, podemos, igualmente, recorrer a um exemplo: “A superação dos modelos explicativos advindos das posturas fundadoras está exatamente na compreensão da comunicação como um processo compartilhado e mediado pelos meios" $" 113$. Da mesma forma que no parágrafo anterior, podemos nos perguntar:

111 Esta observação ecoa a justificativa apresentada por SIGNATES (1998) na introdução de seu "Estudo sobre o conceito de mediação". O fato desta menção já ter a idade de uma década, serve, no mínimo, como um alerta para o fato de que a questão ainda está em aberto.

112 Reservamo-nos o direito de não referenciar este exemplo, retirado de texto acadêmico a título de ilustração.

113 Idem. 
- A comunicação é, obrigatoriamente, um processo mediado?(Ou mediador? Ambos?)

- Os meios medeiam ${ }^{114}$ a comunicação?

Note-se que ambos os exemplos mencionados são facilmente interpretados nos textos onde ocorrem, mas se essa clareza e consistência dependem de interpretação e contextualização, podemos afirmar que ambas as qualidades não são inerentes ao "mediar", tal como é empregado nos textos educomunicativos (e fora deles também ${ }^{115}$ ).

Por fim, além de todas as justificativas invocadas, há o risco pouco convidativo de expor ao descrédito linhas de pesquisa importantes, mas cujos estatutos não consigam atender satisfatoriamente aos juízos metodológicos mais exigentes.

A esse respeito, consideramos fundamental acrescentar o ponto de vista de SANTOS (1988), o qual nos alerta que

“(...) negar ou desconhecer a mediação equivale a mover-se dentro do pensamento mágico, desconhecendo o processo real do pensamento. 'Mediação ou magia', tal parece ser o dilema. Quando uma mudança - seja real ou fíctícia - sobrevém, costuma-se recorrer a diversas categorias, por exemplo a de causa ou a de efeito mágico, mas é mais raro que se tenha a valentia de recorrer até a mediação. Esta seria distinta e eqüidistante entre a causa dos físicos e a magia, e nunca assimilável a nenhuma delas" (SANTOS, 1988: 595) ${ }^{116}$.

Ao delinearmos nosso objeto de estudo, deparamo-nos com a certeza de que essa discussão está fadada ao rápido envelhecimento: finda a pesquisa, é bem provável que os dados elencados careçam de atualidade, tanto quanto as reflexões que neles se baseiem necessitem ser retificadas. Entretanto, consideramos que nossa abordagem, sem pretender, em momento algum encerrar a questão, complementa com idéias novas as reflexões teóricas que, mesmo compondo um volumoso conjunto, revelam-se tão insuficientes quanto esparsas.

Assim, não obstante o caráter sisifista da tarefa, há que empreendê-la.

114 Outra observação pertinente: a conjugação correta de mediar no presente é poucas vezes observada: "medeio, medeias, medeia, mediamos, mediais, medeiam" (HOUAISS, 2007).

115 Tomando emprestadas as palavras de SIGNATES: “(...) se a noção de mediação se tornar um conceito do tipo guarda-chuva, que permite levar até à mais simplória das totalizações - tudo é mediação (logo, nada o é) - todo o valor heurístico propiciado pela abertura de suas possibilidades pode redundar apenas em generalizações sem qualquer utilidade teórica" (SIGNATES, 1998: 47).

116 A tradução é nossa. 


\subsubsection{Mediação: uso, ou abuso lexical?}

Com certeza, o termo mediação é muito popular nos dias de hoje. Uma busca rápida em qualquer livraria on-line remeterá, no mínimo, a três dezenas de títulos. Mesmo que a maior parte deles se refira diretamente à área jurídica ${ }^{117}$, podemos verificar um número crescente de títulos nas áreas de Ciência da Informação ${ }^{118}$, Psicologia, Bioquímica ${ }^{119}$, Teologia e Religiosidade ${ }^{120}$, Arte $^{121}$, Pedagogia ${ }^{122}$, Comunicação e - o que é sintomático nos setores de atividade em que estas duas últimas se interseccionam dentro de um contexto em que a Tecnologia é uma influência determinante.

Um exemplo emblemático dessa última tendência corporifica-se na chamada EaD (Educação a Distância), vertente que, não por acaso, embasará nossa análise sobre a aplicabilidade da MTE .

Um dicionário-padrão da língua portuguesa registra "1.3 Rubrica: termo jurídico. que atua como árbitro entre pessoas, grupos, partidos, facções ou países que estão em contenda ou têm pontos de vista divergentes acerca de determinada questão, com a finalidade de compor uma composição amigável das partes" (HOUAISS, 2007).

118 "A idéia da mediação acaba por cobrir coisas tão diferentes entre si, que vão das velhas concepções de "atendimento ao usuário" à atividade de um agente cultural em uma dada instituição - museu, biblioteca, arquivo, centro cultural - à construção de produtos destinados a introduzir o público num determinado universo de informações e vivências (arte, educação, ecologia, por exemplo), à elaboração de políticas de capacitação ou de acesso às tecnologias de informação e comunicação, etc. Desse modo, uma definição consensual de mediação parece impraticável: sempre contextualizada, torna-se um conceito plástico que estende suas fronteiras para dar conta de realidades muito diferentes entre si". (DAVALLON, 2003 apud ALMEIDA, 2007).

119 Substâncias que promovem ligações de caráter somático, como por exemplo, os neurotransmissores (endorfina, dopamina, etc.) são denominadas "mediadores".

120 Segundo um clássico dicionário de filosofia, "Uma função mediadora entre os deuses e os homens foi reservada na antigüidade aos demônios" (ABBAGNANO, 1982: 628). Essa mesma atribuição teria sido exercida, ao longo da história, por divindades como Mithra, e chegado até nós pela filosofia cristã de Santo Agostinho, que afirma, em sua Sumula Theologica, que “(...) 'somente a Cristo compete ser mediador de modo simples e perfeito' enquanto anjos e sacerdotes são de preferência instrumentos de Mediação". (apud ABBAGNANO, op. cit.). Curiosamente, a existência de serviços esotéricos on-line reintroduziu a perspectiva mística na semântica da mediação, devidamente "atualizada" dentro de um contexto pedagógico (RAMOS, 2002: 49).

${ }_{121}$ Há um entendimento que enquadra as tecnologias como suporte e "meio de transmissão" da expressão artística contemporânea, não só nas modalidades visuais, mas também na música. De certa forma, tal referência atualiza a discussão benjaminiana/adorniana plasmada na Indústria Cultural: "O registro sonoro sobre um suporte físico enfatiza o processo de 'coisificação' da música, ao mesmo tempo que elimina a necessidade de conexão espaço-temporal entre a performance e a escuta.” (IAZZETTA, 2006: 08).

122 "A mediação do outro desperta na mente da criança um sistema de processos complexos de compreensão ativa e responsiva, sujeitos às experiências e habilidades que ela já domina. Mesmo que ela não elabore ou não apreenda conceitualmente a palavra do adulto, é na margem dessas palavras que passa a organizar seu processo de elaboração mental, seja para assumi-las ou para recusá-las."(FONTANA, 2005: 19). 
A larga utilização da palavra expõe certa tendência à versatilidade ${ }^{123}$ e também à extensibilidade $^{124}$ de seu uso a diversos âmbitos, o que torna mais desafiadora a tarefa de precisar-lhe sentido e significado. Por outro lado, podemos notar que se evidencia também um desgaste precoce do termo ou, pelo menos, uma popularização que conspira contra a precisão epistemológica que dele se espera nos círculos acadêmicos.

Não que alimentemos a ambição de fixar o léxico, tarefa impossível até para os lingüistas. Basta-nos aqui:

(a) que o emprego de "mediação" e outros termos derivados do verbo "mediar" ganhe um contorno mais distinto dentro do campo emergente da Educomunicação;

(b) que essa maior clareza seja emprestada, especificamente, àquela vertente educomunicativa a que denominamos "Mediação Tecnológica na Educação", o objeto que delimitamos para o nosso estudo e

(c) que a significância construída com base em nossas análises possibilite uma proposição de âmbito conceitual e metódico extensível, em princípio, aos campos da Comunicação e da Educação.

Não entendemos que a falta de um consenso estrito a respeito da mediação desvalorize, em algum grau, a série de conquistas epistemológicas meritórias que se acumularam (e se acumulam, a cada dia) por conta das pesquisas em comunicação ${ }^{125}$. Ao contrário, procuramos nos referenciar em várias contribuições nessa linha para desenvolver nossa própria análise, buscando a contextualização histórica de nosso objeto de pesquisa e acompanhando a trajetória do conceito de mediação através dos campos da filosofia e da sociologia, até os domínios da comunicação.

123 "Capacidade de ser diverso nas suas habilidades, saberes, empregos, aproveitamento etc." (HOUAISS, 2007).

124 "Qualidade de extensivo", o qual, por sua vez, é o "que se aplica ou que é válido para um maior número de pessoas, objetos ou casos" (HOUAISS, 2007).

125 SANTOS diria que "A ausência da mediação dentro do conjunto de preocupações teóricas não impede que esteja atuando continuamente, como demonstra até o mais superficial exame de linguagem e da mais simples produção intelectual ." (SANTOS, 1988: 595 - a tradução é nossa) 


\title{
$2.2 \mathrm{O}$ conceito de mediação e suas transformações históricas
}

Uma observação importante sobre o conceito de mediação é ser ele um dos mais precoces, persistentes e recorrentes dentro da Filosofia. É certo que ele retorna ciclicamente ao centro dos debates, numa espécie de espiral ascendente, cada vez mais ampla, envolvendo um número maior de elementos e relações.

Da idéia do "termo médio", presente em Aristóteles, até a "teoria das mediações” de SERRANO/MARTÍN-BARBERO ${ }^{126}$, um longo e tortuoso percurso foi construído. Resgataremos, tanto quanto possível dentro deste espaço exíguo, as relações que consideramos mais valiosas para o entendimento da MTE.

\subsubsection{A mediação na Filosofia Clássica}

Se tomarmos como ponto de partida a obra de Aristóteles, nos deparamos com o mencionado "termo médio", o qual

\begin{abstract}
"no silogismo exerce uma função mediadora no raciocínio, visto que torna possível a conclusão a partir da premissa. Em geral, a mediação num raciocínio é o que torna possível esse raciocínio; com efeito, num processo discursivo, tanto dedutivo como indutivo, são necessários termos, ou 'juízos', que 'façam a mediação' entre o ponto de partida e a conclusão" (MORA \& TERRICABAS, 1994: 1918-1919).
\end{abstract}

Essa modalidade de mediação pode ser categorizada como não-dialética, por se tratar de um "artifício pedagógico" que "unindo o termo maior e o menor realizava uma mediação passiva entre dois extremos" (SANTOS, 1988: 596). Nesse nível de mediação, tudo o que se revela é a implicação de um conceito em outro, conclusão a que se pode chegar sem a necessidade de recorrer a um 'intermediário' (op. cit.). Ainda segundo SANTOS (1988), a verdadeira contribuição de Aristóteles para o conceito de mediação é a idéia metafísica de que ela é necessária para levar o ser à perfeição, passando da potência para o ato.

126 Consideramos, como outros autores, que o destaque para a mediação social enquanto eixo organizador epistêmico em comunicação é o mesmo que se evidencia primeiro em SERRANO e, mais tarde, em MARTÍN-BARBERO. Os dois autores serão suficientemente referenciados no próximo subitem. 
Segundo ABBAGNANO (1982, 627), entre as idéias de Aristóteles - que balizaram nossa concepção original de mediação - e as de Hegel — que elevou o conceito ao patamar de categoria - , constituem posições marcantes os postulados de Port-Royal ${ }^{127}$, John Locke ${ }^{128}$ e D’Alembert ${ }^{129}$.

Nesses autores, a mediação aparece de forma muito semelhante, como um elemento abstrato (idéia, raciocínio, operação lógica) cuja interpretação confirma (PORT-ROYAL), demonstra (LOCKE) ou esclarece (D’ALEMBERT) as posições antagônicas que se contrapõem em uma análise. Não podemos deixar de notar a proximidade dessas concepções com o princípio dialético expresso na tríade Tese $X$ Antítese $=$ Síntese, e que talvez justifique a retomada da Mediação enquanto conceito e sua proeminência na filosofia contemporânea.

Sem desconsiderar a importância filosófica que talvez possa representar, reservamonos a prerrogativa de não examinar os conceitos de mediação místico-religiosos, por entender que essa abordagem não encontra suporte semântico, filosófico ou epistemológico que possa ser localizado dentro da linha de estudos comunicativos à qual nos dedicamos.

É interessante assinalar ainda (talvez mais a título de contraprova) a ausência conceitual e terminológica da mediação — indício de sua incompatibilidade epistêmica na obra de filósofos importantes como Nietzsche (mormente por sua orientação antidialética e anti-idealista) e Max Weber, sendo que este último, se tomado como representante do pensamento burguês, opera intelectualmente pelo viés do dualismo, inviabilizando operações mediatórias (SANTOS, 1988: 600).

Trataremos, agora, daquela concepção que se estabelece como um divisor de águas na progressão conceitual da mediação: a filosofia de HEGEL.

127 Antonin Arnauld (dito) de PORT-ROYAL (1585-1638) fazia parte do movimento criado na abadia que leva esse nome pelo bispo de Ypres, Cornelius JANSEN (1585-1638) e que contaria ainda com a adesão do matemático Blaise PASCAL (1623-62).

128 Ilustre filósofo inglês, John LOCKE (1632-1704) é considerado o expoente máximo do Empirismo, e um dos pilares sobre os quais se apoiaria o Iluminismo.

129 Jean Le Rond D'ALEMBERT (1717-1776), físico e matemático, estudou ainda Direito e Medicina antes de optar pela Filosofia. Foi contemporâneo de VOLTAIRE e partícipe do chamado Enciclopedismo. 


\subsubsection{A mediação em Hegel}

A filosofia de Georg Wilhelm Friedrich HEGEL (1770-1831) é considerada por pesquisadores sociais modernos (BOTTOMORE, 1988; SANTOS, 1988) como o ponto de origem da acepção que a mediação adquire nas Ciências Sociais - particularmente, no campo da Comunicação (SIGNATES, 1998). A significância desse filósofo em relação a nosso objeto de estudo reside não só no fato dele efetivamente ter dado um "salto quântico" em relação aos seus predecessores e contemporâneos, mas por ter construído um referencial metodológico para o tema (mediação dialética) que, por via direta ou indireta, levou ao desenvolvimento da Teoria das Mediações na comunicação social.

O conceito hegeliano de mediação - ou, mais propriamente, uma das acepções hegelianas de mediação ${ }^{130}$ — foi apropriado criticamente por Marx e seus seguidores (assim como o próprio método dialético), voltando a influenciar, por retroalimentação, as teorias sócio-comunicativas da segunda metade do século XX. O fato de nos referirmos à mediação em Hegel como um conceito mutável reflete a evolução do significado que a ele se empresta nas obras do filósofo alemão.

À parte seus desdobramentos etimológicos ${ }^{131}$, ao estudarmos a mediação em seu sentido hegeliano, deparamo-nos primeiramente, com a noção de conhecimento mediato/imediato da realidade ${ }^{132}$.

De acordo com MORA \& TERRICABAS:

"Hegel concebe o conhecimento mediato em relação com uma idéia de reflexão. Assim como a luz é refletida por um espelho e volta à sua fonte, o pensamento é também refletido ao ricochetear sobre a realidade ou as coisas 'em sua imediatividade'. Transforma-se então em saber mediato ou 'reflexivo'.” (MORA \& TERRICABAS, 1994: 1919)

130 Segundo BOTTOMORE (1988, 263), neste caso, a obra referencial seria Princípios da Filosofia do Direito (Grundlinien der Philosophie des Rechts).

131 "O alemão para '[o] meio' é [die] Mitte. Este gera um adjetivo mittel ['meio'] e um outro substantivo, [das] Mittel [originalmente ' $\{0\}$ centro, a coisa que está no centro ou no meio', mas agora 'os meios ou recursos, o que serve para se atingir uma finalidade ou PROPÓSITO']. Gera também diversos verbos, especialmente mitteln ['ajudar alguém a, ajustar, combinar, mediar', por exemplo, num litígio, numa desavença], o que hoje é obsoleto mas deixou mittelbar ['mediato, indireto'] e unmittelbar ['imediato, direto'] e ainda vermitteln ['conseguir união, mediar, conciliar' etc.]. O particípio passado de vermitteln, vermittelt ['mediado, indireto'] é usado em contraste com unmittelbar. Ambos dão origem a substantivos abstratos, Vermittelung ['mediação'] e Unmittelbarkeit ['imediatidade']" (INWOOD, 1993: 217).

132 Etimologicamente, descobrimos que o inglês mediacy traduz o sentido de "estado ou qualidade do que está sendo mediado". Não há correspondência natural em nosso idioma, exceto pela construção artificial "mediácia". Ver também nota de rodapé na página 125. 
Hegel vai além, e qualifica o saber imediato como superior ao mediato, o que podemos entender, num certo sentido, como a "verdade original", não-mediada e, portanto, ligada ao Todo. Entretanto, ele próprio admite que

em outro sentido, o saber mediato é superior ao imediato, embora então a imediatidade de que se trata já não seja a das coisas que estão simplesmente 'aí', mas a das coisas em sua conexão racional com o Todo. Por isso, em Hegel, o que se pode denominar 'imediatidade superior' não é possível sem a mediatidade, isto é, sem mediação. (MORA \& TERRICABAS, 1994: 1919)

Assim, a mediação surge como uma operação necessária à materialização do conhecimento filosófico, não só para a compreensão, mas também (ou principalmente) para a intervenção sobre a realidade, no sentido de torná-la melhor. A busca de Hegel — tida como frustrada - pela concretude dialética da mediação, afasta-o conceitualmente dos empiristas e também dos iluministas, ou

Em outras palavras, a reflexão exclui não somente a imediação que é intuição abstrata, isto é, o saber imediato, mas também a "relação abstrata", isto é, a mediação de um conceito diverso (as provas de Locke) que Hegel julga própria (e com razão) do século do iluminismo. (ABBAGNANO, 1982: 628)

Segundo SANTOS (1988), o conceito de mediação aparece em Hegel, num primeiro momento, em modalidade pré-dialética, conforme se evidencia na análise feita pelo filósofo na obra Fenomenologia do Espírito. Nesta, Hegel (o filósofo, no papel de "mediador") interpreta a dicotomia em dois exemplos conflituosos: a relação entre amo e escravo e a relação entre Antígona e Creonte $^{133}$ :

“Ao tratar da certeza sensível na Fenomenologia do Espírito, chega à conclusão de que a única saída até o conhecimento universal, para além do sensível, é a mediação mútua do sujeito e do objeto. Trata-se de uma mediação fechada, dual, que se limita a atestar a 'existência', o que 'é' e não as determinações" (SANTOS, 1988: 596 - tradução nossa).

Dessa forma, a ação dialética em Hegel é, ela própria, identificada como "mediação" resultando num juízo novo, o qual não residia, originalmente, nos extremos mediados. O único - e enorme - "senão" é o fato do filósofo não ter fixado claramente a natureza ontológica da mediação, o que se evidencia quando ele trata da "automediação" e

133 Personagens da famosa tragédia Antígona de Sófocles. 
da "alienação" 134 como mediação de outrem (SANTOS, 1988). Essa aparente contradição, ou obscuridade intencional no processo mediador, justificar-se-ia pela orientação idealista (não-assumida) de Hegel, fato apontado pela crítica marxista:

"Não é estranho que Marx censurasse esta maneira de proceder na Crítica da Filosofia do Estado de Hegel (Secção B). A mediação idealista era empregada por Hegel em mediações fictícias, fazendo-nos ver uma espécie de 'sociedade mutuamente reconciliada' na qual o estado se legitimaria como mediação necessária entre a sociedade civil e a sociedade política" (SANTOS, 1988: 597 tradução nossa).

Críticas à parte ${ }^{135}$, a preocupação de Hegel, de certa forma, é a mesma demonstrada pelo Marxismo: “expressar, as 'relações concretas' e não simplesmente as 'relações abstratas' (como ocorre com a idéia de mediação na lógica clássica)." (MORA \& TERRICABAS, 1994: 1919).

A consolidação do conceito, na obra do filósofo alemão, evidencia-se pelo estabelecimento de três possibilidades distintas (INWOOD, 1993):

(1) a mediação física, necessária, por exemplo, para entender como um broto transforma-se em árvore por meio de um processo de crescimento;

(2) a mediação epistêmica, identificada com o reconhecimento da própria existência (autoconsciência), ato que se realiza por meio da educação ou da reflexão filosófica (como no cogito ergo sum de Descartes) e

(3) a mediação lógica, que se verifica no silogismo de que "o Ser Puro é imediato mas a essência é mediatizada por um processo lógico" (INWOOD, 1993: 217).

Voltando ao marxismo, vale dizer que a passagem da mediação para a mediação dialética não consolida apenas o conceito da mediação, mas o próprio conceito de “dialética”. Este será o próximo ponto de nossa discussão.

\footnotetext{
134 Conceito que os marxistas também adotam, mas ao qual reservam acepção distinta.

135 Não deixa de ser curioso como, por recusar o princípio do "Salto da Fé" (que dispensa a mediação humana), Hegel tenha merecido as críticas e a animosidade de seu contemporâneo Kierkegaard.
} 


\subsubsection{A mediação na Filosofia Marxista}

O papel de Marx como “aprimorador” das idéias de Hegel sobre a mediação, a despeito de sua profunda dissidência em relação ao papel do Estado enquanto mediador, coloca o marxismo na rota de nossas análises, o que nos leva a inquirir:

Afinal, como a mediação é conceituada no Marxismo?

Antes de responder a essa pergunta, convém esclarecer que é difícil falar de um conceito de mediação comum a todas as correntes marxistas, uma vez que várias delas simplesmente rejeitam-no, devido a suas raízes idealistas.

Por outro lado, em Marx, há uma ressignificação do termo, o qual, não raro, é identificado com o próprio trabalho: "com o mesmo espírito, Marx indicou o trabalho (ou 'diligência') como o mediador entre o homem e a natureza, identificando assim na atividade produtiva do 'ser natural automediado' a condição vital da autoconstituição humana” (BOTTOMORE, 1988: 264).

Além do trabalho ${ }^{136}$, passam a fazer parte do repertório filosófico marxista conceitos relativos ao dinheiro, à troca e à propriedade privada como mediações (de “segunda ordem"). O esforço de Marx e de seus seguidores caminhou no sentido de emprestar uma dimensão humana, real e não-idealista à mediação, o que a aproxima da noção de causalidade.

\footnotetext{
"Mas, ainda que Marx não tenha se ocupado em fixar as diferenças entre causalidade e mediação, emprega claramente a mediação nos momentos decisivos: assim o trabalho é o mediador por excelência. Nesta mediação do trabalho encontramos os três elementos que intervêm em toda mediação: matéria prima trabalho mediador - produto.” (SANTOS, 1988: 598 - tradução nossa)
}

\footnotetext{
136 Talvez a passagem mais citada de O Capital seja justamente aquela em que o raciocínio da mediação se evidencia: "Pressupomos o trabalho numa forma em que pertence exclusivamente ao homem. Uma aranha executa operações semelhantes às do tecelão, e a abelha envergonha mais de um arquiteto humano com a construção dos favos de suas colméias. Mas o que distingue, de antemão, o pior arquiteto da melhor abelha é que ele construiu o favo em sua cabeça, antes de construí-lo em cera. No fim do processo de trabalho obtémse um resultado que já no início deste existiu na imaginação do trabalhador, e portanto idealmente. Ele não apenas efetua uma transformação da forma da matéria natural; realiza, ao mesmo tempo, na matéria natural seu objetivo, que ele sabe que determina, como lei, a espécie e o modo de sua atividade e ao qual tem de subordinar sua vontade. E essa subordinação não é um ato isolado" (MARX, 1996: 297-298). Sintomaticamente, Vygotski se lembraria de anotar esse mesmo trecho na conferência que o trouxe a Moscou, em 1925 (LURIA, 2001: 25).
} 
Além do autor de $O$ Capital, ideólogos como Lenin e Williams ${ }^{137}$ marcaram posição a respeito da mediação dialética. Já teóricos do quilate de Althusser parecem simplesmente ignorá-la (SANTOS, 1998).

Particularmente no caso de Williams, a tentativa de explicar a mediação, a constatação do grau de dificuldade e o virtual abandono dessa tarefa compõem estágios sucessivos da trajetória de análise que o pesquisador galês dedicou nosso objeto de estudo, enquanto categoria dialética. Segundo aponta SIGNATES:

\begin{abstract}
"No esforço que este autor desenvolve para adequar ou superar o conceito de mediação, ele faz uma extensa análise das noções de tipificação e homologia, passando por categorias muito utilizadas pelos teóricos de Frankfurt, como correspondência e imagem dialética. Ao fim e ao cabo, Williams conclui que (1979, p. 110) 'nenhuma das teorias dualistas, expressa como reflexo ou mediação, e nenhuma das teorias formalista e estruturalista, expressa em variantes de correspondência ou homologia, pode ser plenamente levada à prática contemporânea, já que de modos diferentes todas elas dependem de uma história conhecida, de uma estrutura conhecida, de produtos conhecidos"” (SIGNATES, 1998: 39-40).
\end{abstract}

De um modo geral, todas as teorias fundantes da Sociologia contemporânea - em sua grande maioria, na linha dialética - contribuíram com largos aportes conceituais para o campo da Comunicação. Mais do que simplesmente amoldar essas idéias e métodos às suas demandas, os estudos comunicacionais apropriaram-se dessa bagagem com grande proficiência, influenciando, a partir de suas próprias leituras, a cultura dentro e fora do mundo acadêmico.

Caso a construção de nosso raciocínio tenha seguido um rumo satisfatório, a passagem epistemológica da filosofia-sociologia para a abordagem especificamente comunicacional dar-se-á sem grandes traumas. A esta altura, vamos "preparando o terreno" para os aportes epistemológicos de outros campos do conhecimento, com um olhar bem distinto sobre a questão da mediação (e, por extensão, da MTE). As pontes de diálogo que buscamos só poderão ser consolidadas dentro de uma ótica interdisciplinar e interdiscursiva.

137 Raymond WILLIAMS (1921-1988), natural do País de Gales e autor de Politics and Letters (1979), foi acadêmico, crítico e novelista. 


\subsection{A Teoria das Mediações}

A partir deste ponto, analisaremos a questão tal como foi tratada cronologicamente, apropriando-nos das postulações de SERRANO (1986), MARTÍN-BARBERO $\left(2003^{138}\right)$ e OROZCO GÓMEZ (1997), acrescidas das contribuições de outros autores, conforme sua pertinência.

\subsubsection{As contribuições de Serrano}

Para iniciar, recorreremos a um dos exemplos mais notáveis de reforma do pensamento acadêmico comunicacional: Manuel Martín Serrano ${ }^{139}$. Esse pesquisador espanhol, graças a seus trabalhos publicados entre as décadas de 1970-1980 — com destaque para La Mediacion Social (1977), Teoria de La Comunicacion (1982), além da La Producion Social de La Comunicacion (2004) — reorientou a pauta dos debates no campo da Comunicação, vinculando as práticas de pesquisa (ainda concentradas na análise dos meios produtores) ao arcabouço social das correntes teóricas dialéticas da sociologia.

Para nosso estudo, mostra-se fundamental a menção à obra de 1977, sobre a qual a pesquisadora mexicana Cecilia Cervantes BARBA comenta que

\footnotetext{
“A tendência e os propósitos de Martín Serrano começam a se aclarar em 1977 quando publica La Mediación Social, livro no qual esse pesquisador desenvolve sua interpretação da mediação ao mesmo tempo em que define o lugar que ocupa a investigação sobre a mediação social dentro dos estudos da comunicação e do social em geral" (BARBA, 1992: 38 - tradução nossa)
}

Algumas de suas reflexões mais importantes sobre o tema da mediação, bastante desenvolvidas a posteriori, compõem o verbete "Mediação", do Dicionário de Ciências Sociais da UNESCO, que tomamos como fonte para nossa investigação. Nessa obra, a

$138 \mathrm{O}$ ano refere-se à segunda edição em língua portuguesa, a primeira edição espanhola de De los medios a las mediaciones. Comunicación, cultura y hegemonia, remonta, como se sabe, ao ano de 1987.

139 Sociólogo, professor e, mais tarde, diretor do Instituto de Comunicação da Universidad Complutense de Madrid (Espanha). Seu papel na construção da Teoria das Mediações foi assim descrito por BARBA: "No seio da formalização das ciências da comunicação surge, por volta da década de setenta, o estudo da mediação social com a proposta metodológica de Manuel Martín Serrano, que localiza a mediação no plano cognitivo, diferentemente da pespectiva sócio-espacial de Jesús Martín-Barbero.” (BARBA, 1992: 38 - tradução nossa). 
abordagem do tema resulta numa síntese do conceito de mediação em SERRANO, a partir da qual destacamos alguns pontos dignos de menção:

1) A Mediação - num sentido mais geral - equivale a um sistema que objetiva instituir um modelo de ordem, o qual

(1) seria aplicável à totalidade dos campos dentro das ciências humanas;

(2) possibilitaria (na verdade, praticamente, obrigaria) o delineamento de tipos mediadores e categorias de mediação;

(3) ajudaria a controlar as formas de representação da realidade — mas nunca a própria realidade, já que "Confundir a realidade com o modelo é justamente o tipo de mecanismo que dá origem à opressão intelectual" (SERRANO, 1986: 735).

2) As Mediações — num sentido mais específico - seriam os próprios modelos de representação da realidade, englobando os procedimentos metodológicos neles infusos por ação do mediador, de modo que,

(1) cada uma delas pode ser isolada e formalizada;

(2) "coexistem no tempo diversos modelos de mediação que impedem a visão totalizadora do mundo." (SERRANO, 1986: 736);

(3) "cada uma dessas mediações obriga a fragmentar a visão da realidade, impondo a cada setor do conhecimento um modelo do qual não se escapa, por não haver substituto para ele.” (SERRANO, 1986: 736).

Tomando como base esse postulado sociológico e metodológico a respeito da mediação, Serrano estabelece uma definição primordial para o conceito:

"Define-se a mediação como a atividade de controle social que impõe limites ao que poderia ser dito (e às maneiras de dizê-lo) por meio de um sistema de ordem." 140 
Abstraindo essa definição dentro de um contexto mais especificamente "comunicacional", Serrano estabelece um paralelo entre mediação e código, assinalando que "Um modelo de mediação é um código sob um duplo ponto de vista." Os dois pontos de vista aos quais o autor se refere são:

I. como sistema codificante (no sentido restrito de código ${ }^{141}$ ) equivalente a "estrutura", ou seja, "modelos que permitem massificar a diversidade do acontecer de um ponto de vista sociocultural compartilhado a priori pelo emissor e pelos receptores."(op. cit.);

II. como elemento coercitivo (no sentido mais amplo de código ${ }^{142}$ ) equivalente a “ideologia", isto é, parâmetros que determinam os critérios de verdade "que servem para corrigir os desvios do conhecimento e do comportamento com relação a um único propósito prefixado" (op. cit.).

Essa identificação com o complexo código/ideologia permite que a mediação mantenha ou restitua a ordem do significado - a qual se constrói com a informação, isto é, desde que esta não ameace o consenso estabelecido na compreensão. Dito de outra maneira: " $\mathrm{Na}$ medida em que os instrumentos de mediação utilizam os mesmos supersignos ${ }^{143}$ empregados para pensar e atuar, a significação da mensagem ${ }^{144}$ é uma constante cultural." (op. cit.).

Entendemos assim, o mediador social/cultural como um "operador de significados" cuja ação define, dentro do sistema, as constantes culturais (identificadas, grosso modo, com o valor informativo da mensagem) com vistas a assegurar a compreensão inequívoca e, conseqüentemente, possibilitar a previsão e a ação ${ }^{145}$.

A contribuição teórica de Martín Serrano não se esgota em estabelecer o conceito de mediação social, mas avança na proposta de uma metodologia de estudo que categoriza as

141 Referenciado em La estructura ausente de ECO (1972).

142 Referenciado em Durkheim.

143 Expressão emprestada de A. A. Moles, definidos, em sua natureza cultural, como "Formas normalizadas de combinar os signos mais elementares que são aceitas no universo da memória perceptiva." (op. cit.).

144 Referida à estabilidade das noções, coincidindo, portanto, com as formas estabilizadas da linguagem.

145 Percebemos, aqui, um sutil deslocamento da esfera social para a intervenção política. 
mediações ${ }^{146}$. O referencial para essa categorização não está (e nem poderia estar) fora da esfera de influência da ideologia (no sentido marxista do termo), assim:

"Este novo enfoque em sociologia encaminha-se para a análise dos 'mediadores culturais' que desempenham uma função essencial dentro do sistema de controle social. Os meios de comunicação são concebidos precisamente como mediadores culturais que 'transportam' formas de ver o mundo ou 'visões ideológicas' que têm uma estrutura lógica específica e que, portanto, podem-se estudar mediante a análise lógica (...)." (BARBA, 1992: 38 - tradução nossa)

Com base no conceito marxista de ideologia, Serrano proporá a categorização de quatro Tipos de Ordem na mediação, os quais se referem a modelos específicos, sendo:

\section{Modelos Mosaicos de Mediação}

2. Modelos de Mediação Hierárquica

3. Modelos de Mediação Articular

4. Modelo Latente ou Abstrato de Mediação

Procuramos sintetizar as categorizações da mediação em Serrano dentro de um quadro esquemático (quadro 15), com uma preocupação eminentemente didática. O fato é que, em nossa leitura, parece não haver uma preocupação estruturalista em Serrano que permita uma interpretação tão cabal das mediações sociais e culturais. Principalmente no que tange aos modelos de mediação Articular (3) e Latente/Abstrato (4), surgem lacunas que tentamos preencher sob a preocupação de não desvirtuar a construção epistemológica do autor espanhol.

Há que se levar em conta dois fatos: primeiro, que as categorias mencionadas tendem a se caracterizar mais como níveis da leitura possíveis de um fenômeno social ou comunicativo, no sentido que mais nos interessa - do que propriamente como enquadramentos funcionais do tipo fechado. As categorias também apresentam certo grau de imbricação e contingência (mais do que de permeabilidade), notando-se, por exemplo, que o modelo articular identifica-se, muitas vezes, dentro de uma estrutura mosaica, assim como o modelo latente, por sua vez, é deduzido de uma mediação articular.

146 De resto, a metodologia de pesquisa social é um tema que ocupa enorme espaço na obra deste pesquisador, ao lado da epistemologia e da investigação de campo, desde a década de 1960 (BARBA, 1992). 


\begin{tabular}{|c|c|c|c|c|}
\hline & $\begin{array}{l}\text { MODELOS } \\
\text { MOSAICOS } \\
\text { DE } \\
\text { MEDI AÇÃO }\end{array}$ & $\begin{array}{l}\text { MODELOS DE } \\
\text { MEDI AÇÃO } \\
\text { HI ERÁRQUI CA }\end{array}$ & $\begin{array}{l}\text { MODELO DE } \\
\text { MEDI AÇÃO } \\
\text { ARTI CULAR }\end{array}$ & $\begin{array}{l}\text { MODELO DE } \\
\text { M. LATENTE } \\
\text { OU ABSTRATO }\end{array}$ \\
\hline $\begin{array}{l}\text { Hipótese } \\
\text { subjacente }\end{array}$ & $\begin{array}{l}\text { Os fatos são } \\
\text { independentes } \\
\text { e igualmente } \\
\text { prováveis. }\end{array}$ & $\begin{array}{l}\text { Os fatos estão } \\
\text { embutidos, } \\
\text { contidos uns } \\
\text { nos outros. }\end{array}$ & $\begin{array}{l}\text { Os fatos são } \\
\text { interdependentes } \\
\text { e ordenados. }\end{array}$ & $\begin{array}{l}\text { Os fatos são } \\
\text { abstraídos de } \\
\text { uma ordem } \\
\text { subjetiva. }\end{array}$ \\
\hline Ação & $\begin{array}{l}\text { Desune os } \\
\text { dados, } \\
\text { desarticula-os } \\
\text { e apresenta- } \\
\text { os sem } \\
\text { distinção. }\end{array}$ & $\begin{array}{l}\text { Ordena os } \\
\text { dados em } \\
\text { camadas, } \\
\text { restringindo } \\
\text { seu acesso. }\end{array}$ & $\begin{array}{l}\text { Define os dados } \\
\text { em relação a } \\
\text { uma ordem } \\
\text { social pré- } \\
\text { estabelecida. }\end{array}$ & $\begin{array}{l}\text { Ordena os } \\
\text { dados com } \\
\text { relação às } \\
\text { variáveis } \\
\text { latentes. }\end{array}$ \\
\hline Objetivos & $\begin{array}{l}\text { Tornar os } \\
\text { signos } \\
\text { inteligíveis e } \\
\text { legíveis. }\end{array}$ & $\begin{array}{l}\text { Conservar e } \\
\text { manter a } \\
\text { virtude e o } \\
\text { poder dos } \\
\text { signos. }\end{array}$ & $\begin{array}{l}\text { Buscar as regras } \\
\text { do sistema de } \\
\text { forma que se } \\
\text { possa substituir } \\
\text { um mediador por } \\
\text { outro sem } \\
\text { alterar a } \\
\text { substância. }\end{array}$ & $\begin{array}{l}\text { Anular as } \\
\text { contradições, } \\
\text { apresentado-as } \\
\text { como variações } \\
\text { de tema. }\end{array}$ \\
\hline $\begin{array}{l}\text { Tipo de } \\
\text { ordem }\end{array}$ & $\begin{array}{l}\text { De } \\
\text { seqüências. }\end{array}$ & De implicação. & $\begin{array}{l}\text { De estrutura } \\
\text { estável e uso } \\
\text { variável. }\end{array}$ & $\begin{array}{l}\text { De estrutura e } \\
\text { uso variáveis. }\end{array}$ \\
\hline $\begin{array}{l}\text { Exemplo em } \\
\text { comunicação }\end{array}$ & A imprensa. & A oralidade. & A telel & isão. \\
\hline $\begin{array}{l}\text { Visão do } \\
\text { mundo } \\
\text { ( suposta) }\end{array}$ & $\begin{array}{l}\text { "Os fatos } \\
\text { podem estar } \\
\text { dispostos com } \\
\text { maior } \\
\text { variedade, e } \\
\text { onde se inclui } \\
\text { toda variedade } \\
\text { de fatos } \\
\text { possíveis." }\end{array}$ & $\begin{array}{l}\text { Atemporal, a } \\
\text { ser conservado, } \\
\text { cada um é } \\
\text { responsável por } \\
\text { ocupar um } \\
\text { lugar na } \\
\text { hierarquia. }\end{array}$ & $\begin{array}{l}\text { Conserva a } \\
\text { mesma forma } \\
\text { inicial, na } \\
\text { medida em que } \\
\text { as trocas dos } \\
\text { significantes são } \\
\text { realizadas } \\
\text { respeitando-se a } \\
\text { forma. }\end{array}$ & $\begin{array}{l}\text { O mundo } \\
\text { abstrato é a } \\
\text { estrutura que } \\
\text { introduz uma } \\
\text { visão da } \\
\text { realidade do } \\
\text { ponto de vista } \\
\text { da inércia, da } \\
\text { ausência de } \\
\text { todo } \\
\text { movimento. }\end{array}$ \\
\hline $\begin{array}{l}\text { Contexto } \\
\text { social e } \\
\text { ideológico }\end{array}$ & $\begin{array}{l}\text { Capitalismo } \\
\text { liberal }\end{array}$ & $\begin{array}{l}\text { Feudalismo } \\
\text { medieval }\end{array}$ & \multicolumn{2}{|c|}{$\begin{array}{l}\text { Sociedade contemporânea } \\
\text { "televisiva" }\end{array}$} \\
\hline
\end{tabular}

Quadro 15 - Síntese dos tipos de mediação em Manuel Martín Serrano ${ }^{147}$

147 Referências: SERRANO (1986: 737, 738) e BARBA (1992). 
Em segundo lugar, essas categorizações metodológicas datam do período "préInternet" e parecem soar, bastante, como uma resposta às postulações de McLuhan, centradas na discussão entabulada por causa da televisão e seu uso social. Seria desejável, sem dúvida, uma releitura mais profunda de Serrano - que não cabe no âmbito desta tese — reformulando suas categorias à luz não só dos "novos meios" interativos, mas das novas discussões que eles suscitam, no plano epistemológico e no plano sociológico.

Encontramo-nos, neste momento, ante um marco conceitual que requalifica o debate sobre a mediação comunicativa: o marco divisor da teoria das mediações tem sua base sociológica em Serrano, mas encontra seu release na obra de Jesús Martín-Barbero, menos, talvez, no momento em que ela foi proposta e mais na releitura efetuada por Guillermo Orózco-Gómez, cuja repercussão possibilitou a existência de trabalhos de "reconstituição de percurso" e de aplicação do conceito, como pretende ser esta tese.

\subsubsection{As contribuições de Martín-Barbero}

Dando continuidade à análise que principiamos, recorreremos ao marco filosófico em comunicação que é a obra Dos Meios às Mediações - Comunicação, cultura e hegemonia de Jesus Martín-Barbero. Ao longo de suas páginas, o pesquisador hispanocolombiano desdobra um caleidoscópio de reflexões socioculturais com foco nas manifestações midiáticas (principalmente a TV) abordadas pelo viés teórico da corrente investigativa dos "usos e gratificações" 148 .

Em momento algum ele defende um conceito fechado de mediação ${ }^{149}$, mas fornece, em troca, indícios valiosos sobre o local onde elas - as mediações - se situam no sistema de produção cultural contemporâneo ${ }^{150}$.

148 Esse enquadramento teórico provém de Guillermo Orozco Gómez, que assinala, em relação à mencionada corrente de Usos e Gratificações, que esta possui duas vertentes: "Uma, que é a internacional, fundamentalmente manifesta pelos Estados Unidos, Grã-Bretanha e Alemanha, onde se colocou a ênfase nas gratificações e se deixou de lado os usos; e, por outro lado, a vertente latino-americana que, a partir de Jesús Martín-Barbero, ganhou mais força, aprofundando-se nos usos e menos nas gratificações" (OROZCO GÓMEZ, 1997: 55 - tradução é nossa).

$149 \quad$ Essa constatação já havia sido enunciada por Signates: "O conceito de mediação é citado 37 vezes dentro da obra. Dessas citações, em 21 oportunidades o autor o utiliza como categoria vinculante de dicotomias específicas e, em maioria, antinômicas. Nas demais, efetua simples citações, sem um 
Em suas próprias palavras:

"O que busco com esse mapa é reconhecer que os meios de comunicação constituem hoje espaços-chave de condensação e intersecção de múltiplas redes de poder e de produção cultural, mas também alertar, ao mesmo tempo, contra o pensamento único que legitima a idéia de que a tecnologia é hoje o "grande mediador" entre as pessoas e o mundo, quando o que a tecnologia medeia hoje, de modo mais intenso e acelerado, é a transformação da sociedade em mercado, e deste em principal agenciador da mundialização [em seus múltiplos e contrapostos sentidos]" (MARTÍN-BARBERO, 2003: 20).

Na verdade, Martín-Barbero fala do Campo das Mediações, que, segundo ele, "é constituído pelos dispositivos através dos quais a hegemonia transforma por dentro o sentido do trabalho e da vida da comunidade". Sua obra, como um todo, sintetiza a corrente de estudos comunicacionais que sucedeu a "Era McLuhan"151, deslocando radicalmente o foco das pesquisas dos media (conjunto dos meios de comunicação de larga escala) para os fatos e relações socioculturais que com os quais eles interagem osmoticamente.

Juntamente com Serrano, Martín-Barbero é considerado o propositor principal da abordagem conhecida como Teoria das Mediações, sobre a qual nos esclarece o pesquisador Mauro Wilton de Sousa, lembrando que "a sua significação em comunicação mostra-se instigante quando propõe que a comunicação deva ser analisada segundo as mediações que a envolvem, mais do que apenas pelos meios de que se serve" (SOUSA: 2001, 31).

De nossa parte, observamos que o sentido atribuído a "medios" no original, tanto quanto no português "meios" — ambos referenciados no latim "media" (plural de medium) — aplica-se ao conjunto dos "meios de comunicação e informação para o público", como aponta o dicionário especializado ${ }^{152}$.

comprometimento explícito com sua definição.” (SIGNATES, 2007: 41). Antes desse autor, Orozco Gómez já observara que "Sem dúvida, Martín-Barbero não elaborou o conceito de mediação em termos mais concretos" (OROZCO GÓMEZ, 1997: 74). (Tradução nossa.)

150 Há que se levar em conta que, tanto MARTÍN-BARBERO quanto OROZCO GÓMEZ, desenvolvem o conceito de mediação (o segundo mais que o primeiro) em torno dos processos de recepção televisiva. Apesar de nosso interesse priorizar a MTE, não podemos, como já mencionado, olvidar tais referências.

${ }_{151}$ Aqui tomamos emprestada a expressão conforme usada por Octávio Islas (ISLAS: 2008). Este pesquisador, quase que na contracorrente dos estudos comunicativos latino-americanos atuais, propõe a reavaliação de vários postulados de McLuhan, empreitada na qual ele não se encontra só. Exemplo importante para esta afirmação é o interesse crescente de uma nova geração de autores ingleses e americanos, entres os quais podemos citar Christopher Horrocks (Reino Unido), Gary Genosko (Canadá) e Paul Levinson (E.U.A.). 152 No caso, Dicionário de Informática, Multimídia e Realidade Virtual (COLLIN, 2001: 261). 
Não obstante o fato de levarmos em conta essa mesma definição para uso geral nesta tese (reafirmar o óbvio?), buscaremos também trazer à tona o resgate das acepções originais (reavaliar criticamente?), fiéis à crença de que, se a etimologia, por si só, não explica os objetos e eventos do mundo de hoje, pelo menos, indica o ponto de partida para sua construção.

Assim, se em Serrano a mediação e seu emprego denotam uma linha de continuidade partindo do referencial hegeliano-marxista, em Martín-Barbero emerge um jogo de sutilezas no qual a mediação funciona como um caminho para transcender a lógica dualista na análise comunicacional. Neste ponto, estabelece-se uma ruptura entre a abordagem de Martín-Barbero e as propostas de análise em comunicação oriundas do culturalismo "engajado" - porque estas rejeitam a cultura popular, fonte de pesquisa nas mediações — e também dos partidários de McLuhan — por sua contaminação funcionalista.

Segundo Cecilia C. Barba:

"A comunicação vista somente como dominação perpetuada através do controle social que exercem os meios massivos não permite entender a outra parte do problema, a que remete à cumplicidade dos receptores que aceitam esse estado de influência externa opressora. O entendimento do que sucede no outro extremo, onde se localizam os sujeitos que permitem a entrada dos efeitos dos meios massivos, constitui um campo de reflexão e de estudo para este investigador (...)" (BARBA, 1992: 83 - tradução nossa).

Definir com precisão o sentido da mediação em Martín-Barbero, extraindo dele o enquadramento epistemológico que buscamos para a MTE não é tarefa das mais fáceis ${ }^{153}$. Cabe lembrar que diversos autores respeitados já emitiram juízos sobre a questão, quase sempre para embasar uma análise específica, apropriando-se, nesse caso, de uma das categorizações — uma vez que há diversas — utilizada pelo pesquisador colombiano em sua obra. Mais raramente, vemos acadêmicos ocupando-se da tarefa de interpretar (ou re-

153 Nem das mais frutíferas, de acordo com alguns trabalhos. SIGNATES, na conclusão de seu ensaio denominado Estudo sobre o conceito de mediação (o qual precede esta tese em quase uma década), anota que: "É nesse sentido parece que torna-se preciso admitir, após essa varredura conceitual, que o uso da noção de mediação tem sido problemático, denotando alguma razão de ser, na atitude de [Raymond] Williams correto indagar, a esta altura, pelas prováveis razões que levaram teóricos do porte de Martín-Barbero e Orozco Gómez a insistirem em sua utilização, chegando a colocá-lo, como é o caso de Barbero, como um conceito central em sua importante obra" (SIGNATES, 1998: 47). 
interpretar, mediar talvez?) o conceito tal como descrito em De Los Medios a Las Mediaciones.

O mais reconhecido “decodificador” das mediações em Martín-Barbero é, sem dúvida, o comunicólogo mexicano Guillermo Orozco-Gómez (1954-), o que nos leva a reservar, na seqüência, um subitem específico para apresentar suas contribuições,.

De nossa parte, cabe destacar algumas considerações, expostas a seguir:

I. Mais que uma teoria construída para interpretar fatos comunicativos, a proposição de Martín-Barbero assume contornos de uma proposta de intervenção política gestada dentro de uma perspectiva pós-modernista a partir do campo da comunicação;

II. a preocupação principal manifesta na obra de Martín-Barbero é o rompimento com a razão dualista, identificada não apenas com o funcionalismo estruturalista, mas também com o funcionalismo marxista. No entendimento do pesquisador colombiano, ambas as correntes incorrem no erro básico de dicotomizar a realidade, pois “jogam com reflexos automáticos e verticais que impedem uma compreensão real da dimensão do histórico" (BARBA, 1992: 91);

III. embora sejam nítidas a precedência e a influência das idéias de Serrano sobre a mediação sobre a abordagem de Martín-Barbero, estas se diferenciam em um ponto bastante nítido: enquanto o autor de La Mediación Social preocupa-se em construir uma epistemologia própria para a Comunicação, de certa forma isolando-a, como campo, em relação ao corpo das Ciências Sociais, o autor de De Los medios a Las Mediaciones apóia sua exegese no contexto da cultura, fora do qual, para ele, não há sentido em se estudar as mediações. Assim:

\footnotetext{
"No caso da comunicação, entre o tradicional emissor-meio-mensagem-receptor, não há uma relação direta, senão que toda relação é mediada. Quer dizer que em todo processo de investigação não há uma relação direta entre os componentes. Entender, assim, como mediada esta relação, torna importante ver os contextos nos quais se dão essas relações e não só as relações mesmas. Ou seja, nada está conectado diretamente com nada, senão que há uma série de mediações que incidem e conformam a interação entre um e outro dos componentes." (OROZCO GÓMEZ, 1997: 114 - tradução nossa).
} 
IV. essa abordagem inédita e específica do fenômeno da mediação no campo comunicacional vai implicar em alguns pressupostos, conforme nos apresenta OROZCO GÓMEZ (1997), que seriam:

(a) imprevisibilidade (impossibilidade de previsão) no desenrolar ou desenvolver de um objeto de estudo;

(b) necessidade de incorporar elementos do contexto;

(c) identificação das principais fontes de mediação e as relações entre os distintos componentes no contexto referido.

V. ainda segundo OROZCO GÓMEZ (op. cit.), a (a) socialidade, a (b) ritualidade e a (c) tecnicidade ${ }^{154}$ constituem-se nas mais importantes das práticas sociais processos de ação social concretas — que se identificam nas mediações. De forma similar, o conceito central de sujeito social pode, sem grande esforço, ser identificado na figura que tratamos aqui como mediador.

Reforçamos que as contribuições de Orozco Gómez e outros estudiosos do trabalho de Martín-Barbero são indispensáveis para compreender as transformações semânticas pelas quis passou o conceito de mediação nas ciências sociais e, principalmente, o salto epistemológico realizado pelos sociólogos-comunicadores que publicaram seus trabalhos, em idioma espanhol, nas últimas quatro décadas.

Do ponto de vista particular de nosso objeto de estudo, no entanto, percebemos algumas grandes lacunas quando tentamos aplicar tanto as categorias conceituais quanto a metodologia investigativa orientada por estes pesquisadores em suas obras mais conhecidas. Acreditamos que essa ausência de uma atenção específica mais consistente para a Mediação Tecnológica deve-se não só à centralidade ocupada pela televisão à época em que tais pontos de vista se consolidaram, como também à própria natureza imprevisível da "revolução digital" - encabeçada pela tríade microcomputador, Internet e cultura

154 Estender-nos-emos mais na análise dessa tríade, com ênfase na tecnicidade, quando tratarmos das contribuições de OROZCO GÓMEZ. 
digital —, que subverteu de assalto, com incrível rapidez, a pauta dos debates em comunicação.

Justiça seja feita, em trabalhos mais recentes, nenhum dos investigadores mencionados deixou de acrescentar pelo menos algumas indicações críticas de como tais fenômenos podem-se alinhar às perspectivas por eles delineadas.

Da parte de Martín-Barbero, chamam-nos a atenção pelo menos dois comentários dirigidos especificamente para a questão tecnológica envolvida na mediação cultural. O primeiro nos fala das transformações sociotécnicas observadas nos meios, com destaque para a década de 1980:

\begin{abstract}
"A revolução tecnológica que vivemos não afeta apenas cada um dos meios, como também produz transformações transversais que se evidenciam na emergência de um ecossistema comunicativo, conformado não só por novas máquinas e meios, senão por novas linguagens, escrituras e saberes, pela hegemonia da experiência audiovisual sobre a tipográfica, e a reintegração da imagem ao campo da produção de conhecimentos. Ele está incidindo tanto sobre o sentido e o alcance do que entendemos por comunicar, como sobre a particular deslocalização de cada meio nesse ecossistema e nas relações de uns meios com os outros" (MARTíNBARBERO, 2002a: 68 - nossa tradução).
\end{abstract}

Podemos notar, no âmago desse comentário - contextualizado em uma obra sobre as interfaces entre comunicação e educação ${ }^{155}$ —, a constatação de que, efetivamente emerge uma nova configuração social e cultural (identificada como "revolução tecnológica"), a qual se plasma em um novo ecossistema comunicativo. Por um lado, trata-se de um fenômeno novo, sobre o qual a construção teórica do pesquisador parece ainda buscar um enquadramento mais definido em seu "estatuto das mediações"; mas, por outro lado, parece haver uma leitura mais clara do novo panorama, apoiada em seus desdobramentos sócio-políticos, articulados pelo conceito-chave do ecossistema comunicativo.

Pelo fato de referir-mo-nos a ele em mais de uma passagem, cabe aqui um aclaramento, ainda que parcial, do conceito.

Pois bem, após tê-lo introduzido no texto Retos culturales de la educación a la comunicación (2000), o autor colombiano teve seu conceito apropriado por vários pesquisadores da linha educomunicativa. Por exemplo, SARTORI e PRADO SOARES

155 Referimo-nos ao livro "La Educación desde la Comunicación” (2002). 
(2007), relembra o paralelo possível com as ciências da natureza, notando que ele "Pode ser considerado como o conjunto dos relacionamentos mútuos entre os seres vivos e o meio ambiente. No ecossistema, acontecem trocas e ele está em contínuo dinamismo: não é determinado por seu tamanho, mas por suas estruturas e seus padrões de organização..." (SARTORI e PRADO SOARES, 2007).

Segundo TAVARES JR. (2007),

"Quanto aos conceitos difundidos pela teoria educomunicativa podemos entender ecossistema comunicativo como o conjunto de ações que viabilizem a promoção e ampliação das relações de comunicação entre as diversas pessoas e instâncias que compõem a comunidade educativa. Inclui desde a organização do ambiente até a disponibilização dos recursos. Estimula a descentralização do poder, o diálogo, a interação e a abertura de espaço para diferentes experiências e vivências culturais. Avalia a qualidade das relações interpessoais buscando harmonia e equilíbrio em ambientes em que diversos atores possam conviver com diferentes tecnologias e meios de expressão" (TAVARES JR., 2007: 72).

Essas idéias já são acréscimos ao desenvolvimento efetuado por SOARES (1999), o qual refere-se ao conceito, com certa freqüência, no sentido de abordar a educação:

“A educação pode ser considerada, na verdade, como um dos mais antigos e tradicionais campos do exercício da própria comunicação. Ao mobilizar pessoas em permanente interação, sistematizar e divulgar conhecimentos, reafirmar valores, garantir espaço para as manifestações da criatividade das pessoas nela envolvidas, a educação moderna apresenta-se, hoje, como nunca, como um autêntico ecossistema comunicacional" (SOARES, 1997c: 213).

Ainda no que diz respeito à questão tecnológica, o outro comentário significativo, na obra de Barbero, dá conta de que a mediação hegemônica por trás da suposta revolução tecnológica é, na verdade, a “onipresença mediadora do mercado”. Segundo ele:

"Frente ao consenso dialogal em que Habermas vê emergir a razão comunicativa, desonerada da opacidade discursiva e da ambigüidade política que introduzem a mediação tecnológica e mercantil, o que estamos tentando pensar é a hegemonia comunicacional do mercado na sociedade: a comunicação convertida no mais eficaz motor do desligamento ou inserção das culturas - étnicas, nacionais ou locais - no espaço/tempo do mercado e as tecnologias globais" (MARTÍNBARBERO, 2002b: 15 - tradução nossa).

Nessa leitura, aparentemente "apocalíptica" do papel social da Comunicação, reside na realidade um tom exortativo que nos impele a trabalhar politicamente com a perspectiva da "reconfiguração das mediações em que se constituem seus [da política] novos modos de 
interpelação dos sujeitos e representação dos vínculos que coesionam a sociedade" (MARTÍN-BARBERO: 2002b, 16).

Constatamos, portanto, que algumas das colocações mais recentes do autor de De los Medios a las Mediaciones, é a necessidade de redirecionarmos o potencial dos meios para nos contrapor à lógica neoliberal do mercado hegemônico e totalitário,

\begin{abstract}
"Pois o meio não se limita a veicular ou traduzir as representações existentes, nem pode tampouco substituí-las, senão que passou a constituir um cenário fundamental da vida pública. E o faz reintroduzindo no âmbito da racionalidade formal as mediações da sensibilidade que o racionalismo do 'contrato social' acreditou [hegelianamente] superar" (op. cit.).
\end{abstract}

Longe de ser um pensamento eivado de otimismo ingênuo, esse compromisso político do comunicador — entendido aqui como um mediador cultural privilegiado encontra eco na maioria dos autores contemporâneos nos quais se referenciam os estudos da Comunicação, como é o caso Orozco-Gómez e Nestor Garcia Canclíni ${ }^{156}$. Encontra um paralelo, igualmente, nas idéias referentes ao conceito de Político-Pedagógico adotado ${ }^{157}$ na área da Educação e reafirmado no conjunto de valores inerente ao corpus epistemológico da Educomunicação.

Caso achemos por bem estender esta incitação aos acadêmicos, seria interessante lembrar que se trata de uma teoria social dialética que questiona não só a hegemonia dos meios na sociedade, mas no própria academia onde se estuda e se ensina a produzir a comunicação.

Voltando aos juízos mais recentes da parte do teórico colombiano sobre as mediações, há um texto em particular que merece menção pelo enfoque da mediação tecnológica em termos mais precisos ${ }^{158}$. Nele, o pesquisador re-examina criticamente o conceito de Sociedade da Informação (emprestado de CASTELLS, 1998), observando que ele significa "algo impensável em termos de mera técnica — instrumentos, máquinas ou

156 Este autor escreve: "Não é hora, então, de passar das mediações aos meios? Ou seja: reformular nossos planos de estudo e nossos desempenhos públicos para que o que investigamos e ensinamos, além de renovar o curriculum educacional e formar cidadãos interculturais e democráticos, logre que estes objetivos operem eficazmente nas indústrias culturais?" (CANCLÍNI, 1998: 08 - tradução nossa).

157 Na filosofia da educação, no discurso dos educadores e bem menos, na prática escolar.

158 O texto é Los desafíos estratégicos de la sociedad de la información, publicado no $n^{\circ} 44$ da revista colombiana Sygno y Pensamiento (2004). 
aparatos - e também em termos do espaço-tempo da sociedade nacional, a qual tem sido até agora a categoria central das ciências sociais.” (MARTÍN-BARBERO, 2004: 10).

Em relação ao teor social e político que sustenta a suposta revolução tecnológica, Barbero adverte sobre "a cumplicidade discursiva entre a modernização liberal e o saber tecnológico", um arranjo que conspira para acentuar — ao invés de diminuir — o quadro de exclusão social no mundo.

Segundo ele

\footnotetext{
"a mediação tecnológica se espessa cada dia mais, ao transtornar nossa relação com o mundo, mas essa mudança não remete só à técnica, faz parte do processo muito maior e profundo de racionalização do mundo que, segundo Max Weber, constitui o núcleo mais duro e secreto do movimento da modernidade" (MARTÍNBARBERO, 2004: 11 - tradução nossa).
}

Concluímos, assim, este subitem, evidentemente longe de esgotar as menções sobre a mediação e seus conceitos correlatos na obra de Martín-Barbero (nos quais continuaremos nos apoiando, ao longo desta tese). Acreditamos, todavia, ter mantido uma linha de argumentação enfatizando a transformação de nosso objeto de estudo na obra dos pesquisadores mais significativos nos modernos estudos em comunicação. Esta lista não pode deixar de fora a obra de Orozco.

\subsubsection{As contribuições de Orozco Gómez}

Num primeiro momento, podemos considerar que a obra desse comunicólogo mexicano é um desenvolvimento das idéias originalmente introduzidas por Barbero. Entretanto, o volume e a densidade de sua produção atestam uma propriedade de pensamento absolutamente significativa de per se.

Podemos creditar-lhe, também, uma síntese conceitual das mediações de Serrano e Barbero, como quando ele declara que o que "subjaz de comum em ambos os tipos é que a mediação está referida precisamente aos meios. Assim, nesta compreensão limitada, são os meios, os mass media, os que medeiam o conhecimento e transmissão dos fatos sociais às 
audiências" (OROZCO GÓMEZ, 1998: 94) ${ }^{159}$. Entre os dois teóricos ibero-americanos, seguramente, ele se apóia mais no colombiano, segundo ele próprio assinala ao falar da influência que a leitura de De los medios a las Mediaciones exerceu sobre suas escolhas e descobertas enquanto pesquisador da comunicação ${ }^{160}$.

Em sua obra Televidencia: perspectivas para el análisis de los procesos de recepción televisiva (1994), Orozco já apresenta uma proposta metodológica bastante amadurecida e uma interpretação bem estruturada das mediações voltada para o estudo da recepção televisiva:

"Em um esforço para resgatar a mediação para o terreno da mediação televisiva, proponho que se a entenda como um 'processo estruturante' que configura tanto a interação dos membros da audiência com os meios, como a criação por parte deles do sentido dessa interação" (OROZCO GÓMEZ, 1994: 74 - tradução nossa ).

Quatro anos depois, ele voltaria a fazer uma síntese das concepções históricas da mediação comunicacional, esclarecendo que

“o conceito de 'mediação' já existia anteriormente como tal nos estudos de comunicação. Na literatura anglo-saxônica, já desde finais dos [anos] setenta, se encontra a mediação nos processos de ver televisão como sinônimo de 'intervenção', especificamente referida a ações conscientes de educadores e comunicadores para modificar a recepção televisiva" (OROZCO GÓMEZ, 1998: 93 - tradução nossa).

Da "tradução" que ele faz, em seus próprios termos, das idéias que se originam em Barbero, surgem indícios importantes para efetuar, em nível metódico-metodológico, operações de análise inferencial que demonstram a aplicabilidade da teoria das mediações ao estudo quantitativo de objetos comunicacionais.

159 Interessante notar como esse ponto de vista é questionado por SIGNATES quando anota que “Mediação não é intermediação. Mesmo que permaneçamos na discutível 'função' das instituições de comunicação como intermediários entre grupos e instituições sociais [...], chamar tais instituições de 'meios de comunicação’ não implica de forma alguma afirmá-las como 'mediações'.” (SIGNATES, 1998: 40).

160 Segundo ele relata, quando terminava sua tese de doutorado em educação em Harvard (E.U.A.), travou contato com a obra do autor colombiano e com a alternativa que ela oferecia em contraposição ao uso instrucional dos meios de comunicação que imperava no ambiente acadêmico estadunidense. Ele nos conta que “(...) foi justamente aqui, nesta encruzilhada, de onde a obra de Jesús Martín-Barbero me deu a chave, que sintetizo [de memória] em uma de suas próprias frases: 'Não foram só os paradigmas, senão os feitos obstinados da América Latina, os que mudaram os objetos de estudo dos pesquisadores da comunicação’. Descobrir essa idéia, não só me deu a confiança necessária para minha proposição, como também se estabeleceu, desde então, como princípio em meu trabalho como pesquisador da comunicação" (OROZCO GÓMEZ, 1998: 94 - tradução nossa). 
Um exemplo da importância dessa tarefa assumida por Orozco é sua explanação sobre as práticas sociais evocadas por Barbero, expressa nestes termos:

\begin{abstract}
"Sem proporcionar uma definição precisa do que entende por 'prática social', novamente Martín-Barbero nos coloca frente a uma substanciação provocativa que nos permite compreendê-la. Para ele, uma prática social comporta três componentes ou dimensões. O primeiro é a 'socialidade', que entende como essa dimensão interpessoal e coletiva que escapa à racionalidade institucional incluída a dos meios e tecnologias da informação - e que se inspira e orienta em outras racionalidades - e eu diria também - , em outras sensibilidades como aquelas subjacentes nos afetos, no poder, na luta, na constituição de identidade, no gênero, na etnia. (...) Uma segunda dimensão da prática é a 'ritualidade'. Por tal, Martín-Barbero assume essa permanência que transcende o meramente espontâneo na comunicação e que confere à prática justamente sua dimensão de prática. Se em algumas ocasiões a ritualidade comporta certa dose de mecanicismo, de mera repetição, seu desdobramento supõe também uma boa dose de criatividade e de reflexividade, na medida em que as situações em que se manifesta a ritualidade nunca são exatamente iguais (...). A terceira dimensão (...) é a "tecnicidade", que propõe como essa característica, rebaixando o meramente instrumental, dos processos de comunicação, por exemplo, permite elucidar novas sensibilidades e linguagens. Essa dimensão não é, portanto, externa ou aleatória aos processos, mas se apresenta como parte consubstancial deles" (OROZCO GÓMEZ, 1998: 95 tradução nossa).
\end{abstract}

O excerto acima nos interessa sobremaneira, uma vez que nos introduz ao conceito basilar de tecnicidade, identificado como uma prática social possível. Convém esclarecer que corresponde, nada menos, ao cerne de nossa problemática na MTE, quando insistimos no fato de que, em educação, não é a tecnologia quem conduz a mediação, mas justamente o contrário.

Dito por Orozco Gómez:

"Distinguir que o veículo não é o processo permite compreender, por exemplo, que a comunicação não é determinada pelos meios, nem muito menos reduzida a eles. (...) Mas, sobretudo, permite entender que a informação, embora suporte a comunicação, não pode ser seu sinônimo, como já há algum tempo vem insistindo a literatura internacional, por exemplo quando se faz alusão a essa suposta 'sociedade de informação' na qual habitamos." (OROZCO GÓMEZ, 1998: 96 tradução nossa).

Não é só o afã de sintetizar os pontos obscuros da filosofia de Martín-Barbero que orienta a leitura que o pesquisador mexicano faz das mediações: ao que parece, sua preocupação mais presente é construir e aperfeiçoar toda uma metodologia analítica embasada no paradigma das mediações, a qual converteu-se na tônica de seus trabalhos na última década. Um fato pertinente para ilustrar essa afirmação pode ser identificado na 
transposição dos vários exemplos de mediação citados em De los medios a las Mediaciones em quatro categorias (“tipos") ${ }^{161}$, claras o bastante para sustentar uma análise qualitativa:

Mediações individuais, entendidas como

"as que provêm de nossa individualidade enquanto sujeitos cognoscentes e
comunicativos, isto é, a psicologia e as ciências da comunicação dizem que as
pessoas percebem através de certos esquemas mentais de significados [a ciência
psicológica enfatiza principalmente os esquemas, os culturalistas diriam que mais
que esquemas, são repertórios], pelos quais outorgamos o sentido à nova
informação" (OROZCO GÓMEZ, 1997: 116 - tradução nossa).

Tais esquemas são chamados, mormente, de "roteiros" (guiones) ${ }^{162}$, os quais definem seqüências específicas de ação e discurso, e que proporcionam aos sujeitos "diretrizes para atuar de acordo com uma representação generalizada do que entendem que se espera deles" (OROZCO GÓMEZ, 1994: 75 - tradução nossa).

(b) Mediações situacionais, constituídas pela situação em que se estabelece a recepção (sempre pensando num exemplo TV/telespectador). Isso se exemplifica se pensarmos nas diferentes experiências que se pode ter assistindo um filme: no cinema, na $\mathrm{TV}^{163}$, sozinhos, em companhia de alguém ou de várias pessoas, etc. Também se incluem aqui os estados de ânimo e as motivações com que os espectadores assistem à programação, pois “Às vezes se quer distrair e se liga a TV; em outras oportunidades se quer uma informação precisa do que se passou e se busca o jornal para

161 Posteriormente, o autor alteraria e ampliaria seu quadro classificatório, acrescentando as mediações de referência, extraídas de dentro das mediações individuais e renomeando as mediações tecnológicas como mediações massmediáticas. De acordo com LOPES (2000), "Orozco parte da necessidade de tornar a conceituação de Barbero mais concreta e, para isso, vem trabalhando numa tipologia de mediações que se encontra em construção [veja-se as distintas publicações], a qual, como toda proposta, exige burilamento na definição e na delimitação de cada uma das mediações propostas. É certo que isso só se consegue através de sua utilização crítica em pesquisas empíricas" (LOPES, 2000: 129).

162 Esta nos parece uma tradução "possível" por conter um certo grau de generalidade e ser usual, por exemplo, em manuais de produção audiovisual. Na verdade, o sentido original da palavra espanhola guión, é intraduzível para o português, já que se identifica com um estandarte levado à frente do prelado ou do rei, ou ainda, um sinal antecipatório de grafia musical, atualmente em desuso (ALMOYNA, 1983: 586).

163 Hoje, forçosamente, teríamos que agregar a esse quadro a Web (sites como o Youtube e similares), o telefone celular com streaming audiovisual e sabe-se lá quantos outros receptores de mídia venham a ser inventados nos próximos anos. 
ler. Às vezes se está cansado, às vezes não" (OROZCO GÓMEZ, 1994: 75 - tradução nossa).

(c) Mediações institucionais, que se estabelecem a partir dos roteiros pertinentes aos diferentes círculos de relação ao qual o espectador está vinculado. Orozco esclarece que:

\footnotetext{
"As instituições utilizam diversos recursos para implementar sua mediação. O poder e as regras são algumas estratégias, assim como os procedimentos de negociação; as condições materiais e espaciais também servem às metas institucionais. A autoridade moral e a acadêmica são outros recursos. A atribuição de identidade e o incremento de classificações que outorguem sentido ao mundo são dois dos aspectos mais importantes das mediações institucionais" (OROZCO GÓMEZ, 1994: 79 - tradução nossa).
}

Este tipo de mediações ocorre no seio da família, na escola, no trabalho, na igreja, no círculo de amigos - em suma - onde quer que se produzam e compartilhem cultura e significados.

(d) Mediações tecnológicas, que se associam ao caráter específico do discurso influenciado pela tecnologia, presente na TV e também no rádio. Na revisão de sua própria tipologia, Orozco optou por chamar este tipo de mediações de Massmediáticas, diferenciando-as em videotecnológicas e radiotecnológicas, de acordo com a especificidade de cada veículo envolvido. $\mathrm{O}$ autor mexicano assinala que

\footnotetext{
"A própria tecnologia exerce uma mediação [como afirma Barbero]. Não é o mesmo ver algo pela TV que escutá-lo no rádio, lê-lo no jornal ou vê-lo no cinema. São tecnologias distintas, linguagens distintas, estratégias de comunicabilidade distintas e isso está, de alguma maneira, influenciando o processo de percepção e a interação com essa informação" (OROZCO GÓMEZ, 1997: 117 - tradução nossa).
}

Um quinto tipo de mediação (e) seria agregado posteriormente no sistema de Orozco, a partir de um desmembramento das mediações individuais: as mediações de referência. Estas incluem "todas aquelas características que se situam num contexto ou ambiente determinado: por exemplo, a idade, o gênero, a etnia, a raça ou a classe social.” (OROZCO GÓMEZ, 1997: 118 - tradução nossa). 
LOPES (2000), com base nesse modelo de mediações múltiplas, estabelece um eixo transversal composto por quatro elementos articuladores, a saber: (1) Nível - que indica plano ou dimensão cultural da mediação; (2) Fonte - que indica a mediação tomada através de sua concretização em ambientes "observáveis"; (3) Lugar - indicando uma localização de natureza relacional e (4) Discurso - indicando em qual âmbito discursivo a mediação se insere. Essa contribuição foi concebida por LOPES para um objetivo bem claro: compor uma estratégia metodológica que pudesse atender à necessidade de concretizar uma pesquisa em torno da recepção de telenovelas. Nesse projeto, tais elementos articuladores, associados aos tipos de mediação estabelecidos por Orozco, resultam num quadro analítico (de número 16), que reproduzimos, fielmente, na seqüência:

\begin{tabular}{|l|l|l|l|}
\hline Nível & Fonte & Lugar & Discurso \\
\hline Estrutural & Posição de Classe & Contexto social & Sistema Lingüístico \\
\hline Institucional & Família & Recepção & Pragmática \\
\hline Individual & Subjetividade & Recepção & Pragmática \\
\hline Videotécnica $^{164}$ & $\begin{array}{l}\text { Gênero Ficcional } \\
\text { Teledramaturgia }\end{array}$ & $\begin{array}{l}\text { Produto } \\
\text { Produção }\end{array}$ & $\begin{array}{l}\text { Semântica } \\
\text { Sintaxe }\end{array}$ \\
\hline
\end{tabular}

quadro 16: Caracterização Analítica das Mediações (LOPES: 2000, 128)

Verificamos assim, que a contribuição de Orozco vai muito além da disposição manifesta de integrar "em função da recepção televisiva a estruturação de Giddens [1984], a teorização da mediação cultural em Martín-Barbero [1986]" e sua própria experiência empírica (OROZCO GÓMEZ, 1994). Além de deixar muito mais claros os conceitos e a aplicação das mediações, ele possibilitou a construção de modelos teóricos com base em categorias que haviam sido pouco ou insuficientemente delineadas por Martín-Barbero.

164 Uma mudança sutil mas significativa: em seu texto, Orozco escreve videotecnológica. 
De modo particular, no entanto, temos duas observações a fazer:

(1) na passagem da classificação tipológica descrita em Televidencia (1994) para a de La investigación em comunicación desde la perspectiva qualitativa (1997), Orozco não só procede à mencionada alteração no quadro, como ainda modifica em número seus denominativos, isto é: primeiro ele fala em mediação individual, mediação situacional, etc. e, depois, em “mediações”. Imaginamos que essa mudança reforça o caráter transitório do modelo ${ }^{165}$, mas é evidente que a multiplicidade, não só dos tipos, mas dos exemplos a eles referentes contidos na abordagem "plural", torna a classificação mais flexível, menos peremptória;

(2) as análises, proposições e categorias teóricas de Orozco, como as de Barbero, surgem na perspectiva de entender os meios de comunicação irradiados, ou a mass media. Mesmo quando tratam de tecnicalidade, ou mediação tecnológica, parece não haver uma articulação direta ou adequada em torno da questão dos new media.

Quanto à nossa segunda colocação, é preciso acrescentar que, verdade seja dita, as novas mídias ${ }^{166}$ (softwares interativos, redes, dispositivos convergentes) não se enquadram na mesma tipologia do rádio e da televisão. Elas não são, por exemplo, "transmitidas" da mesma forma que os mass media, mas são disponibilizadas; também oferecem maior possibilidade de interações, que o marketing se ocupa em trombetear quando fala de interatividade $^{167}$.

Por fim, assim como Barbero, Orozco volta a abordar as mediações, mirando agora o tecnocentrismo ou a tecnofilia, como havia feito antes contra o dualismo positivista e o funcionalismo na comunicação.

165 Talvez ainda faltem as pesquisas críticas empíricas de que falava LOPES (2000).

166 Ainda referidas com a denominação de TICs em vários textos de ambos os estudiosos citados.

167 Discussão árida e volumosa essa: não caberá neste trabalho. 
Assim é que Orozco, em artigo de $2002^{168}$, contrapõe o olhar tecnocêntrico ao olhar sociocêntrico, identificados, respectivamente, com o tecnológico e o comunicacional, e expressando claramente sua posição na contenda:

\begin{abstract}
"Sustentar que, devido precisamente à tecnologia informacional e suas convergências, se eliminam as diferenças de papéis entre sujeitos sociais, que é o que está no fundo desta afirmação, já que os usuários fazem também o papel de produtores é, no mínimo, uma consideração polêmica e falsamente otimista" (OROZCO GÓMEZ: 1997, 118 - tradução nossa).
\end{abstract}

Ele expressa, dessa forma, sua preocupação com a simetria entre o avanço da tecnologia informacional e o crescente despoder ${ }^{169}$ presente nas sociedades latinoamericanas. O próprio argumento que levou ao surgimento da teoria das mediações parece indicar que, do ponto de vista da relação mediática, centrar o processo da comunicação nos meios retira simbolicamente o poder dos receptores.

Para Orozco, também não há dúvida que

“é importante avançar uma compreensão da mediação tecnológica como uma mediação sem precedentes, mas dentro sempre de outras mediações que, entrelaçadas, estão contribuindo de maneira contundente a que vivamos, mais que em uma época de grandes mudanças, em uma 'grande mudança de época", (OROZCO GÓMEZ: 2002, 22 - tradução nossa).

Essa declaração nos situa no seio de uma problemática que pode fornecer bons indícios para o rumo de nossa investigação em curso. Orozco retoma a categoria da mediação tecnológica, reconhecendo sua autonomia, mas insiste que só é possível compreendê-la com base muito mais na mudança ocorrida da cultura literária para a das imagens, a qual não é um fato exatamente novo. Segundo ele, muitas das mudanças que estamos presenciando no âmbito da comunicação social "não se devem todavia ao potencial tecnológico mais recente que se desprenderia das últimas tecnologias ou da racionalidade tecno-informática como tal, mas a estendida presença dos meios e tecnologias menos novas, que surgiram na modernidade" (OROZCO GÓMEZ: 2002, 23 - tradução nossa).

\footnotetext{
168 "Mediaciones tecnológicas e des-ordenamientos comunicacionales”, publicado na revista colombiana Signo y Pensamiento em dezembro de 2002.

169 Este despoder, ao lado do destempo, são os des-ordenamentos sobre os quais o autor discorre no âmbito do artigo a que se refere a nota de rodapé imediatamente anterior a esta.
} 
Por trás desse juízo, Orozco evoca ao menos seis razões que ilustram a persistência das tecnologias "menos novas" como elementos decisivos para o novo ecossistema comunicativo, uma vez que elas, positivamente, não foram suplantadas, pois:

(1) são muito mais que elementos técnicos e instrumentais;

(2) requerem bastante tempo para a aprendizagem e apropriação por parte dos novos usuários;

(3) demandam uma atenção diversificada para gratificar os usuários, pois, mesmo com o advento da web, a audiência televisiva continua grande;

(4) requerem reajustes e acomodamentos vários por parte dos usuários, principalmente quando se leva em conta a escassez de recursos nas sociedades empobrecidas;

(5) custam muito dinheiro para serem atualizadas ao ritmo imposto pelo mercado.

As colocações de Orozco remetem-nos diretamente a nosso objeto de estudo, quando ele fala do destempo causado pela tecnologia na relação entre comunicação e educação: "Um exemplo de destempo é aquele que se manifesta entre o ecossistema comunicativo - e particularmente entre as mudanças tecnológicas no âmbito da informação - e os sistemas educativos e da educação em geral, que vão ficando defasados frente aos primeiros (OROZCO GÓMEZ: 2002, 24 - tradução nossa)". Ou ainda, quando ele, sem abrir mão do paralelo que estabelece entre as mediações tecnológicas e massmediáticas, afirma que

"Se desde o âmbito da comunicação social a visão atual sobre a incorporação do audiovisual-informático à educação comporta uma alta dose de miopia e perversidade, desde as interações dos usuários com a tecnologia de informação, a educação possível e desejável dos sujeitos-audiência comporta um alto grau de incerteza" (OROZCO GÓMEZ, 2002: 30 - tradução nossa). 
Podemos alinhavar algumas considerações parciais sobre o que foi exposto até aqui neste capítulo, reafirmando que a obra de Orozco pode ser entendida quase como uma síntese dos desenvolvimentos de Barbero \& Serrano, muito mais avançada no plano metodológico e digna de assumir, talvez, a proeminência entre as atuais possíveis releituras do "paradigma das mediações".

De outra sorte, mantendo-se na linha da crítica ao "tecnocentrismo" e "as especulações ou os futurismos idealistas" (op. cit.), Orozco continua firme nos trilhos de uma linha sobre a qual se poderia dizer, como disse Canclíni, que é algo como "a escola de Frankfurt despojada de sua melancolia aristocrática e o marxismo liberado do reducionismo" (CANCLINI: 1998, 03 - tradução nossa). Isso nos parece claro na leitura de que, até certo ponto, o pesquisador mexicano admite a importância do elemento tecnológico nas mediações, mas opta por indiferenciá-lo da recepção dos meios (audienciación), inclusive, destacando mais essa faceta. Tal alinhamento, não obstante robusteça a abordagem das mediações em Comunicação, não revela uma preocupação maior segundo nossa visão - com tarefas importantes, tais como:

(a) ocupar-se da análise e avaliação crítica das apropriações tecnológicas presentes no campo da Educação, principalmente daquelas que se apóiam, textualmente, no conceito de mediação;

(b) centrar o debate sobre a MTE no conjunto das interfaces existentes entre a Comunicação e a Educação - o qual entendemos, como já manifesto aqui, como Educomunicação;

(c) tentar compreender, dentro de uma abordagem que atenda, nos planos conceitual e metodológico, às demandas referentes aos processos comunicativos nos espaços educacionais - e da prática educacional enquanto processo comunicativo -, onde a MTE insere-se como categoria/objeto de análise vinculado ao paradigma das mediações. 
Historicamente, essas e outras tarefas que consideramos prementes em nosso texto têm sido desenvolvidas no curso dos projetos educomunicativos do $\mathrm{NCE}^{170}$. Esta afirmação não só conota o fato de que é possível extrair uma delimitação robusta e plausível do conceito de MTE com base no referencial das Teoria das Mediações, como também torna implícito nesta construção o estabelecimento de uma relação epistêmica vinculando as abordagens educativas em sua dimensão filosófica, metódica e prática.

Antes de concretizar este percurso que alinha as mediações comunicativa, educativa e tecnológica (na Educação), sentimos, de nossa parte, certo receio em avançar na prometida conceituação, sem antes examinar umas tantas outras facetas.

Portanto, iniciaremos uma desconstrução analítica da expressão "mediação" e seus termos correlatos, partindo de uma base etimológica.

\subsection{Etimologia de "Meio" e de "Mediação" no Latim}

Nesta seção, fazemos uma análise histórica e epistemológica do(s) conceito(s) de mediação, tal como eles aparecem, principalmente, na obra dos autores mais importantes de nosso QTR. A este primeiro recorte investigativo conceitual, agregaremos algumas análises “instrumentais", buscando a reconstrução do conceito de MTE por um caminho que vai do uso mais específico para o uso mais geral do termo.

Como nossa proposta original implica em nada menos que a reconstrução e proposição de um conceito para a MTE, acreditamos no caminho metodológico de oferecer, ao leitor desta tese, o mesmo traçado lógico que percorremos desde a formulação inicial do problema até o fechamento de nossas conclusões, ainda que provisórias.

O "passo adiante" que nos propomos a dar, nesta etapa, implica em apontar a estreita relação conceitual que detectamos entre o termo "mediação" e o conceito de "mídia".

$170 \quad$ Vide capítulo I, seção 1.2 desta tese. 
Tomemos o verbete transcrito a seguir:

\section{MEDI UM, subs. $\mathbf{N}$.}

I - Sent. próprio: 1) Meio, centro, espaço intermediário (sent. local e temporal): in medio aedium (T. Liv. 27, 48, 17 ${ }^{171}$ ) "no meio do caminho"; medium diei "o meio do dia, isto é: meio-dia": Por extensão 2) Lugar para onde tudo converge, praça pública, sociedade.

II - Sent. figurado: 3) O público: in medium vocare (Cic. Clu. 77 ${ }^{172}$ ) "submeter alguma coisa ao público". 4) Meio, lugar acessível a todos, à disposição de todos (em locuções): consulere in medium (T.Liv 24,22, 15) "tomar medidas no interesse geral"; rem in medio ponere (Cic. Verr. 5, 149 ${ }^{173}$ ) "colocar um assunto à vista de toda gente, isto é, ao alcance de todos"; de medio removere (Cic. Verr. 5, 175) "suprimir (alguma coisa) da vida comum, do seio da sociedade"; e medio excedere (Ter. Phorm. 967 ${ }^{174}$ ) “sair do mundo", isto é: morrer"175.

\section{quadro 17: MEDIUM - verbete do léxico latino-português}

Essa definição será a base inicial de reflexões sobre o sentido dos termos "meio" e "mediação", de sua origem semântica até as variações de seu uso na atualidade.

De princípio, buscaremos localizar o sentido original do latim Medium, de onde temos tanto a derivação direta para o português "meio", quanto a tortuosa via que resultou, no século XX, na expressão "mídia".

Mas qual o sentido original do termo latino medium ?

Como podemos conferir na transcrição do verbete que abre esta seção, existem pelo menos quatro sentidos - dois próprios e dois figurados - todos os quais surpreendentemente próximos do uso que se faz deles, na atualidade e em nosso meio ${ }^{176}$.

\footnotetext{
$171 \quad$ Tito Lívio.

172 Cícero: Pro Cluentio.

173 Cícero: Verrinas.

174 Terêncio: Phormio.

175 FARIA, Ernesto (org.). Dicionário Escolar Latino-Português. Rio de Janeiro: MEC-DNE-CNME, 1956.

176 O duplo sentido (triplo, se considerarmos o trocadilho) é intencional: nosso meio social e o campo da Comunicação.
} 
Assim, temos:

\begin{tabular}{|ll|}
\hline SENTI DO PRÓPRIO & SENTI DO FI GURADO \\
\hline $\begin{array}{l}\text { (1) Meio, centro, espaço } \\
\text { intermediário (sentido local e temporal). }\end{array}$ & (3) O público. \\
\hline $\begin{array}{l}\text { (2) Lugar para onde tudo converge, } \\
\text { praça pública, sociedade. }\end{array}$ & $\begin{array}{l}\text { (4) Meio, lugar acessível a } \\
\text { todos disposição de todos. }\end{array}$ \\
\hline
\end{tabular}

quadro 18: MEDIUM - síntese semântica

Trataremos agora das qualidades associadas ao sentido próprio.

Observemos que Meio, definido como espaço "intermediário", remete à acepção mais comum de "mediação", aquela que equivale a intermediação ${ }^{177}$, localizando o elemento mediador ("sujeito ou ativador da mediação") - ao qual dedicaremos uma atenção maior no capítulo III - num espaço hipotético entre dois elementos mediados (“objetos da mediação"). Neste sentido específico, nossa percepção remete um pouco ao senso comum, mas não deixa de encontrar, também, correspondência em LALANDE (1993), quando ele aponta como sentido primeiro do verbete:

"A. Ação de servir de intermediário, no sentido B, entre dois termos ou dois seres (considerados como dados independentemente desta ação). B. Ação de servir de intermediário entre um termo ou um ser do qual se parte, e um termo ou um ser ao qual se chega, sendo esta ação produtora do segundo, ou pelo menos condição de sua produção.(...)" (LALANDE, 1993: 656).

Esta é a acepção mais corrente, também, na precisão árida da língua inglesa, segundo um dicionário-padrão do idioma ${ }^{178}$ : "alguma coisa que intermedeia o decurso de uma ação, que ocupa uma posição ou representa o ponto médio entre extremos" ${ }^{179}$.

\footnotetext{
177 Relação de sinonímia apontada nos principais dicionários da língua portuguesa (HOUAISS, 2007 e DE HOLLANDA, 2003).

178 Voltaremos a essa questão vernácula no próximo subitem (2.1.3).

179 No original: "1. Something, such as an intermediate course of action, that occupies a position or represents a condition midway between extremes". (The American Heritage ${ }^{\circledR}$ Dictionary of the English Language, 2000/Updated in 2003. Published by Houghton Mifflin Company).
} 
As qualidades associadas ao sentido próprio (1), tanto quanto podemos saber, nos chegaram praticamente inalteradas desde o uso original. As qualidades associadas ao sentido próprio (2), como o caráter público e social do espaço referido, são alusões interessantíssimas, se pensarmos na atualidade e pertinência com que se aplicam, por exemplo, às expressões "mediática" ou "midiática" e, por extensão, aos seus desdobramentos "multimídia" e "hipermídia".

É de se notar como esta segunda acepção tem quase uma relação de acarretamento com os sentidos figurados de "público" ("quem assiste") e "lugar acessível a todos" ("onde" ou de onde se assiste"), os quais conotam, respectivamente, os sentidos de:

(a) acessibilidade - “(s.f.) facilidade na aproximação, no tratamento ou na aquisição" (HOUAISS, 2007);

(b) disponibilidade - "(s.f.) qualidade de quem se acha aberto para receber influências externas, conselhos, novas idéias etc.” (HOUAISS, 2007);

(c) comunhão - " "(s. f.) ato ou efeito de comungar; [1] ação de fazer alguma coisa em comum ou o efeito dessa ação; [2] sintonia de sentimentos, de modo de pensar, agir ou sentir; identificação" (HOUAISS, 2007) ${ }^{180}$.

Não podemos deixar de notar o paralelo curioso existente entre tais expressões vinculadas ao sentido original da mediação e o "conceito-palavra-de-ordem" da era digital, a onipresente interatividade. Tal proximidade semântica vale, no mínimo, um esclarecimento, o qual tomamos emprestado de PRIMO (2004):

"Diante do tecnicismo aparente nos primeiros textos sobre 'interatividade', e provindo de estudos sobre a pragmática da comunicação interpessoal, este autor passa a trabalhar com o entendimento de que a interação é uma 'ação entre' os participantes do encontro (PRIMO, 1997; 1998). Neste sentido, o foco volta-se para a relação estabelecida entre os interagentes e não para as partes que compõem o sistema global. Ao contrário do que possa parecer, a palavra 'interação', segundo

180 Poderíamos inserir, ainda, alguns termos relacionados, tais como "compartilhamento"; "compartição" (co-partição/ co-participação) e "comunidade", mas consideramos que, para o escopo desejado , já temos o suficiente. 
os estudos em lingüística histórica de Starobinski (2002) ${ }^{181}$, não apresenta antecedentes da língua latina clássica. $\mathrm{O}$ autor relata que o substantivo interaction figurou pela primeira vez no Oxford English Dictionary em 1832, apresentado na época como um neologismo, e o verbo to interact, no sentido de agir reciprocamente, em 1839. Já na França, a palavra 'interação’ surgiu apenas depois de outro neologismo: 'interdependência', que figurou em dicionário apenas em 1867” (PRIMO, 2004: 39).

Entender a transformação semântica de "meio" pode nos ajudar a compreender melhor como chegamos ao emprego atual da mediação, mas o fato é que, no Latim romano, esta última expressão é pouco encontrada, ocorrendo, quando muito, a menção da figura do mediâtor $^{182}$ na acepção política do termo.

Interessa-nos a existência do medium latino, associado a um sentido bastante claro (ainda que passível de interpretações figurativas), pelo fato do idioma inglês ter se apropriado dele em grande medida, num processo que resultou, em última análise, na construção da palavra mediation (que originou a "nossa" mediação) dentro de parâmetros semânticos muito próximos daqueles que orientam seu uso nos dias de hoje. De modo semelhante, interessam-nos as derivações e relações semânticas cruzadas passíveis de identificação e análise dentro trajetória $M E I O \longrightarrow>M E D I A R \longrightarrow>M E D I A C ̧ A ̃ O$ e cuja análise, diga-se de passagem, demandou que nos atribuíssemos um certo grau de "liberdade operativa e metódica" que distancia este estudo de uma intenção filológica (que, aliás, não é a nossa) ${ }^{183}$. Recorreremos a um breve estudo interpretativo destas implicações lingüísticas

\subsection{Etimologia de “Meio" e de "Mediação" no idioma inglês}

Se o estudo das raízes latinas - considerando que o Latim, é, provavelmente, a mais influente das línguas européias - ajuda a entender a origem do conceito de mediação, o estudo do inglês (talvez o "mais técnico" dos idiomas, sem dúvida o mais popular e

181 O autor referido por PRIMO é Jean Starobinski, e a obra, Ação e reação: vida e aventuras de um casal (Rio de Janeiro, Civilização Brasileira, 2002).

182 Como, por exemplo, na Metamorfosis de Apuleto (FARIA, 1956: 577).

183 Evocamos, em nosso apoio, a noção de que "Em lingüística, a natureza do significado deu lugar a discussões, sobretudo referentes a seu grau de 'realidade'; todos concordam, entretanto, quanto a insistir no fato de que o significado não é uma 'coisa', mas uma representação psíquica da 'coisa' (BARTHES, 1964: 46)." 
influente nos dias de hoje) é fundamental para compreendermos o que se entende por mediação na atualidade, principalmente dentro do campo da comunicação.

LALANDE (1983) aponta, em nota explicativa, que a origem recente da palavra mediação encontra-se no verbete do idioma inglês mediate ${ }^{184}$.

O léxico inglês atual, pelo menos no que tange especificamente à mediation, pouco nos ajuda quando procuramos pelo sentido exato atribuído a nosso objeto de estudo ${ }^{185}$ :

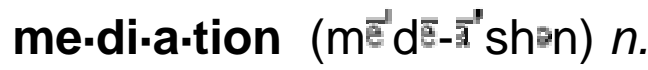 mediação}

1. The act of mediating; intervention.

$\mathrm{O}$ ato de mediar, intervenção.

2. The state of being mediated.

O estado de ser [a situação] mediado (a).

3. Law An attempt to bring about a peaceful settlement or compromise between disputants through the objective intervention of a neutral party ${ }^{186}$.

Lei. Uma tentativa de estabelecer um ajuste pacífico ou compromisso entre antagonistas por meio da intervenção objetiva de uma parte neutra.

quadro 19: MEDIATION - verbete do léxico inglês e tradução ${ }^{187}$

Nete qudro (19), o sentido (1) é reflexivo (mediação como ato de mediar), e só acrescenta a sinonímia parcial de "intervenção". O sentido (2) aponta para o "ser mediado" e o (3) refere-se ao uso jurídico e diplomático do termo.

No sentido jurídico, a mediação ganha um contorno bem claro, definida como "processo pelo qual uma parte neutra procura, valendo-se de uma organização de trocas

184 “1. Esta palavra corresponde ao sentido do adjetivo inglês mediate, mais do que ao francês mediat que nunca se aplica ao próprio elemento intermediário, mas àquele que se liga ao primeiro (ou que deriva) pela intromissão do segundo." (LALANDE, 1993: 656).

185 Nos quadros referentes ao idioma inglês, neste capítulo, as convenções são as seguintes: (1) texto original em fonte não-serifada (media) e tradução em fonte serifada e corpo maior (mídia); (2) Comentários entre [ ] e (3) exemplos em itálico, como no original.

186 In: The American Heritage ${ }^{\circledR}$ Dictionary of the English Language, Fourth Edition copyright (C2000 by Houghton Mifflin Company. Updated in 2003. Published by Houghton Mifflin Company.

187 A tradução é nossa, assim como nos outros quadros (14 e 15). Neles procuramos estabelecer uma convenção fácil de ser compreendida, que consiste em grafar as traduções em fonte diferente abaixo do texto original. 
entre as partes, permitir a elas confrontar seus respectivos pontos de vista para chegar, com a ajuda do mediador, a resolver o conflito que as opõe" (BORRELLI, 2004: 83 ${ }^{188}$ ). O mesmo autor, falando sobre a mediação, assevera que ela "tende a uma procura profunda no eu, o desmascaramento das falsas percepções que tenham favorecido ou determinado o surgimento do conflito" (Idem).

Essa acepção, além de identificar-se com a acepção de $\mathrm{n}^{\circ} 3$ do léxico inglês referencial (vide quadro 19), não difere, substancialmente, de seu significado na área diplomática, sobre a qual F. S. NORTHEDGE assinala quatro implicações:

“(a) real participação na negociação pelo mediador, e deve ser distinguida da prestação de bons ofícios, a qual se restringe a induzir as partes a darem início ou prosseguimento às negociações (...); (b) preocupação com alguma coisa além de direitos ou interesse; (c) recurso a métodos flexíveis e pragmáticos, que vão desde a pressão cordial sobre ambas as partes para que cedam ou continuem a buscar uma fórmula (...); (d) aceitação voluntária da decisão, pois, caso contrário, o processo seria chamado de arbitragem" (NORTHEDGE, 1986: 738).

Por seu distanciamento epistemológico, tais definições aqui incluídas em caráter complementar não serão desenvolvidas nem tomadas como referência para a construção de nosso conceito-chave ${ }^{189}$.

Por outro lado, a referência a mediated ("mediado", ver quadro 20) abre uma nova frente de investigação semântica, já que o substantivo mediate - sem equivalente no léxico formal, mas com precedente de tradução "artificial" como Mediácia"190 - serve de base para inúmeras derivações de importância no vocabulário tecnológico ligado aos estudos da corrente que se denomina new media ${ }^{191}$. Nos últimos anos, essa vertente de pesquisa contribuiu com interessantes conceitos como hypermediacy ("hipermediácia?") e remediation ("re-mediação"? ${ }^{192}$ ), os quais serão referenciados sumariamente no final deste subitem. As referências lexicais associadas a este verbete são, a nosso ver, mais abundantes e interessantes que as encontradas em mediation:

\footnotetext{
$188 \quad$ Na verdade, trata-se de uma paráfrase a partir do jurista italiano Marco BOUCHARD.

189 Embora fosse tentador enxergar nessas definições um paralelo com a mediação pedagógica exercida pela figura do "facilitador" nos sistemas de educação baseados em computador (PAPPERT, 1994).

$190 \quad$ Ver FURTADO (2007).

191 Como referência dessa corrente, apontamos os autores Lev Manovitch (Rússia-E.U.A.) e Mark B. N. Hansen (E.U.A.).

$192 \quad$ Ver BOLTER \& GRUSIN (1999).
} 


\title{
me-di-ate $\left(\mathrm{m}^{\bar{e}^{\prime}} \mathrm{d}^{\bar{z}}-\bar{a} \mathrm{t}^{\prime}\right)$ mediar
}

\author{
v. me-di-at·ed, me-di-at·ing, me-di-ates \\ [variações] mediado, mediando, medeia(am) \\ v.tr.
}

1. To resolve or settle (differences) by working with all the conflicting parties: mediate a labor-management dispute.

Resolver ou acordar (discordâncias) trabalhando com todas as partes em conflito: mediar uma questão trabalhista.

2. To bring about (a settlement, for example) by working with all the conflicting parties.

Estabelecer (um acordo, por exemplo) trabalhando com todas as partes em conflito.

3. To effect or convey as an intermediate agent or mechanism.

Funcionar ou transmitir [algo] como um agente ou mecanismo intermediário.

v.intr.

1. To intervene between two or more disputants in order to bring about an agreement, a settlement, or a compromise.

Interceder entre dois ou mais oponentes de modo a estabelecer um contrato, um acordo, ou um compromisso.

2. To settle or reconcile differences.

Acordar ou reconciliar diferenças.

3. To have a relation to two differing persons or things.

Ter uma relação com duas pessoas ou coisas distintas.

adj. $(-\overrightarrow{1} \mathrm{t})$

1. Acting through, involving, or dependent on an intervening agency.

Atuar por meio de, envolver, ou depender de uma intervenção de terceiros.

2. Being in a middle position.

Estar numa posição intermediária.

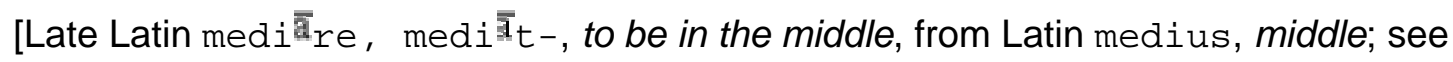
medhyo - in Indo-European roots.]

Latim tardio $[. .$.$] - estar no meio, do latim [...], deio; ver [...] - do radical indo-europeu.$

me'di-ate-ly $\left(-\overline{1} t-\left.\right|^{\bar{S}}\right) a d v$.

mediato

quadro 20: MEDIATE - verbete do léxico inglês e tradução 
De forma concisa, podemos isolar três variações de sentido relativas ao termo:

(a) como verbo transitivo - apresentando-se como um "agente redutor de diferenças", exercendo a função de ajustar as partes em conflito, alinhandoas em relação a um fim comum. Aqui, assinala-se um função ativa e eminentemente prática, já que "se medeia algo", ou melhor, há uma questão que precisa ser dirimida e o mediador possui — ou deve possuir — o poder de solucionar o conflito. Sinteticamente: iniciativa do mediador, foco da ação no conflito mediado;

(b) como verbo intransitivo - apresentando-se como um "elemento-ponte", exercendo a função de minimizar conflitos e estender uma superfície de continuidade entre dois outros elementos (supostamente) antagônicos. Aqui, assinala-se uma função "ligeiramente reativa" do mediador, que entra em ação, não só por sua própria iniciativa, mas pela proximidade/identidade o que remete de novo ao "estar no meio" como ocupar um espaço intermediário — com as partes mediadas;

(c) como adjetivo - emprestado ao elemento mediado ou ao elemento mediador da interação, como qualidade de partícipe no processo mediatório.

Observe-se a existência do termo adverbial mediately ("mediato"), o qual se opõe a immediately ("imediato"), invocando uma alusão acidental aos pressupostos iniciais da mediação em Hegel, da qual tratamos na página 84 deste capítulo.

Certamente, para nossos objetivos de análise, o verbo to mediate, em suas duas acepções sensivelmente distintas, apresenta-se muito mais interessante que o sentido adjetivo que delas deriva. Entretanto, nossa breve análise não parecerá completa se não nos detivermos, também, na etimologia do lexema "medium". 
Vejamos o quadro 21:

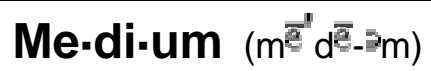

Meio

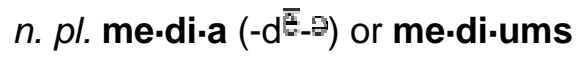

nome. plural. mídia ou meios

1. Something, such as an intermediate course of action, that occupies a position or represents a condition midway between extremes.

Algo, tal como um curso de ação intermediário, que ocupa uma posição ou representa uma condição medial [a meio caminho] entre dois extremos.

2. An intervening substance through which something else is transmitted or carried on. Um agente interventor através do qual algo é transmitido ou transportado.

3. An agency by which something is accomplished, conveyed, or transferred: The train was the usual medium of transportation in those days.

Um agente pelo qual algo é consumado, transmitido ou transferido: O trem era o meio de transporte usual naqueles dias.

\section{4. pl. media Usage Problem}

plural. Uso problemático.

a. A means of mass communication, such as newspapers, magazines, radio, or television.

Um veículo de comunicação de massa, como os jornais, revistas, rádio, ou televisão.

b. media (used with a sing. or pl. verb) The group of journalists and others who constitute the communications industry and profession.

(usado tanto para o singular quanto para o plural) $\mathrm{O}$ conjunto dos jornalistas e outros que constituem a indústria e a profissão das comunicações.

5. pl. media Computer Science. An object or device, such as a disk, on which data is stored. pl. Ciência da computação. Um objeto ou dispositivo, como um disco, no qual dados são armazenados.

quadro 21a: MEDIUM - verbete do léxico inglês e tradução 
Cont.

6. pl. mediums A person thought to have the power to communicate with the spirits of the dead or with agents of another world or dimension. Also called psychic.

$p l$. Pessoa que diz ter o poder de se comunicar com os espíritos dos mortos ou com entes de outro mundo ou dimensão.

\section{7. pl. media}

a. A surrounding environment in which something functions and thrives Um ambiente onde alguma coisa funciona e se desenvolve.

b. The substance in which a specific organism lives and thrives.

A substância na qual um organismo específico vive e se desenvolve.

c. A culture medium.

Um meio de cultura.

8.

a. A specific kind of artistic technique or means of expression as determined by the materials used or the creative methods involved: the medium of lithography.

Um tipo específico de técnica artística ou meio de expressão que é determinado pelos materiais ou métodos criativos envolvidos: o meio da litografia.

b. The materials used in a specific artistic technique: oils as a medium.

Os materiais usados em uma técnica artística específica: óleo como um meio.

9. A solvent with which paint is thinned to the proper consistency.

Um solvente com o qual se dilui tinta até a consistência apropriada.

10. Chemistry: A filtering substance, such as filter paper.

Química: Uma substância filtrante, como um filtro de papel.

11. A size of paper, usually $18 \times 23$ inches or $17 \frac{1}{2} \times 22$ inches.

Um tamanho de papel, geralmente de $18 \times 23$ polegadas ou 17,5 por 22 polegadas.

adj.

Occurring or being between two degrees, amounts, or quantities; intermediate: broil a medium steak. See Synonyms at average.

Ocorrente ou presente entre dois graus, proporções, ou quantidades; intermediária: fritar um bife ao ponto. Ver sinonímia de média [aritmética].

quadro 21b: MEDIUM - verbete do léxico inglês e tradução (continuação) 
Uma primeira constatação nos leva a pensar numa tendência descricionista que comumente se associa ao idioma inglês. Preconceitos à parte, é de se notar que das onze acepções relacionadas, apenas uma ou duas ${ }^{193}$ (4b) referem-se ao entendimento "comunicacional" dos meios, sendo as demais acepções vinculadas aos estudos das ciências físicas, químicas e biológicas, além de referências técnicas diversas.

Partindo da ordem das acepções e da possibilidade de interpretação oferecida pelos enunciados, procuramos extrair as informações semânticas relacionáveis entre os sentidos. Ainda assim, mesmo assumindo certo grau de falibilidade e insuficiência dessas colocações de base epistemológica, observamos que:

1. o idioma inglês reserva um papel que poderíamos chamar, talvez, de eminentemente descritivo, objetivo e operatório para a noção de medium, o que afeta, inegavelmente, todas as construções lexicais substantivas, adjetivas e verbais dele derivadas;

2. esse teor, emprestado, ao que parece, da raiz latina, não permite, num primeiro momento, grandes desenvolvimentos interpretativos fora do princípio da intermediação/interposição de elementos;

3. uma exceção interessante pode ser inferida dos usos do termo em biologia e em química, já que a noção de "meio" remete a uma espécie de espaço circundante que a tudo permeia, algo metafisicamente próximo ao conceito de Éter na física ${ }^{194}$;

4. numa acepção mais "biológica" — esta sim, portável para nosso arcabouço conceitual $^{195}$ —, o meio assume o sentido de "ambiente", operando em paralelo tanto na Microbiologia (meio de cultura) como na Ecologia (meio-ambiente);

193 Com muita boa vontade poderíamos incluir a acepção 5, pela proximidade entre Comunicação e Informação, mas relevando o caráter instrumental do enunciado.

194 Na Física, a chamada teoria do Éter, que contou com o apoio de nomes importantes como os de Isaac Newton (1642-1727), Hendrik Lorentz (1853-1928) e Henri Poincaré (1854-1912), foi suplantada pela teoria da relatividade restrita de Albert Einstein (1879-1955) em 1905.

195 Não podemos nos esquecer das referências analógicas que embasam a noção de ecossistema comunicativo, termo corrente no jargão educomunicativo. 
5. a menção à mediunidade, comunicação interdimensional e/ou espiritual com entidades extracorpóreas, parece ser uma reminiscência ou recorrência da herança teológica do idealismo cristão. Como já referido antes, este é um sentido para o qual não encontramos lugar em nossas inferências;

6. seja por uma analogia viciosa com o uso da expressão medium das ciências naturais, seja por uma persistência ou conservação improvável da etimologia latina, o uso comunicacional reservado à media/mídia (assinalado, não sem razão, com a rubrica usage problem na acepção "4" do verbete transcrito no quadro 21a) já entrou para a história como uma "solução que se tornou problema". No amálgama semântico construído com esse termo, confundem-se vários planos de significado, nivelando modalidades de comunicação (formas/expressões, tecnologias), entidades coletivas (canais, veículos, grupos de intervenção social), indivíduos isolados ${ }^{196}$ e até objetos portadores de informação. Como se não bastasse a polissemia desenfreada sugerida pela palavra, verificamos que ela frutificou, desdobrando-se em confusões verbais consideráveis, tais como o uso controverso de "mediatizar", "midiatizar" e "mediar";

7. a construção metonímica ocorre no uso informacional, no qual a mídia "física" - o suporte material que comporta a informação digital — é identificada com seu próprio conteúdo. É curioso notar que, quando os suportes digitais, como disquetes, CDs e outros passaram a ser comuns em nosso meio, a designação "mídia" foi estendida retroativamente aos suportes de informação analógica, como as fitas magnéticas, os discos de vinil e até os meios impressos. Eis um conceito que remete tanto à "coisificação" da expressão artística quanto à idéia da re-mediation, gestada nos laboratórios do MIT. Para ficarmos numa exposição breve dessa proposta cognitiva e estética - ainda em processo de delimitação e aceitação acadêmica -, cabe uma passagem da obra de seus propositores:

196 Popularizou-se. na área de publicidade, a designação de que corresponde ao profissional responsável pelo planejamento e execução das campanhas veiculadas em "meios massivos": ele é o Mídia. 
"Remediação não começa com a introdução da mídia digital. Nós podemos identificar o mesmo processo ao longo das últimas centenas de anos da representação visual no Ocidente. Uma pintura do artista Pieter Saenredam do século XVI, uma fotografia de Edward Weston, e um sistema computadorizado de realidade virtual são diferentes de várias maneiras, mas eles todos tentam conseguir imediácia ${ }^{197}$ ignorando ou negando a presença do meio e do ato da mediação" (BOLTER \& GRUSIN, 1999: 11 - tradução nossa);

8. não deixa de ter algum significado, também, que a metonímia tratada no item anterior seja extensiva às mídias de transmissão ${ }^{198}$ — rádio, $\mathrm{TV}$, web, etc. —, nivelando e dissolvendo as diferenças entre suporte, veículo e ambiente;

9. o sentido plural, igualmente conservado do latim, também ostenta essa preocupação em reduzir o âmbito do objeto descrito, embora possibilite a construção de conceitos diferenciados (multimedia, hipermedia, re-mediation) a partir da superposição de prefixos;

10. essa construção mais "aglutinante" que "flexiva" de palavras serve bem para construir as idéias de caráter complexo. Nos termos grafados entre aspas (“") da frase anterior, fazemos referência à classificação proposta (na verdade, adotada e desenvolvida) pelo lingüista alemão August Schleicher (1821-1868), conforme relatada por LEROY $(1967)^{199}$;

197 Sobre esse termo, inexistente nos dicionários de português brasileiro, esclarece-nos o professor português José Afonso Furtado (Universidade de Lisboa, Fundação Calouste Gulbenkian): "Por outro lado, as duas lógicas de remediação (remediation) têm uma dimensão social tanto para os produtores como para os observadores. Por isso, a imediácia (immediacy) deve ser entendida em dois sentidos, um epistemológico e outro psicológico. No sentido epistemológico, a imediácia (immediacy) é transparência: a ausência de mediação ou de representação. É a noção de que um medium se pode apagar e deixar o observador em presença dos objectos representados, de modo a conhecer os objectos directamente." (FURTADO, 2007)

198 Anotada na acepção 4a. do quadro 21a.

199 "Quanto à classificação das línguas do mundo - repartição em três classes: línguas isolantes, aglutinantes e flexivas - , baseava-se em critérios internos, propriamente lingüísticos, a saber a estrutura morfológica das línguas consideradas ". À primeira classe pertence o chinês: as palavras são justapostas e as relações gramaticais expressas pela colocação das palavras, por sua entonação e também por palavras gramaticais desprovidas de significação própria, a que os gramáticos chineses chamam de 'palavras vazias' por oposição às 'palavras cheias' que são os semantemas; nas línguas aglutinantes, como o turco, as relações gramaticais são expressas pela aglutinação de elementos diversos à raiz, enquanto nas línguas flexivas - é o tipo das línguas indo-européias - as relações gramaticais são expressas por modificações da própria forma das palavras" (LEROY, 1967: 37). Presente aqui por razões didáticas, cabe esclarecer que essa teoria caiu em desuso e não encontra aplicação na lingüística moderna. 
11. a acepção colateral referente ao uso do medium usado como adjetivo (ex.: ao ponto), não parece comportar significado especial para a construção do conceito de mediação, motivo pelo qual não será analisada.

Mais interessante do que nos perdermos na miríade de acepções possíveis da expressão "mídia" (media) seria, talvez, recorrer ao exercício da "lógica inversa", considerando que a mencionada palavra represente, quiçá, não uma distorção (por diluição, empobrecimento) semântica da raiz que gerou "mediação" (mediation), mas sim um exemplo de recursividade $^{200}$ do sentido, isto é, quando o emprego continuado dentro de um âmbito específico de significação reforça um sentido mais preciso que jazia latente naquele lexema. Em outras palavras: sob este prisma, o que nos habituamos a chamar de "mídia em comunicação" seria a mediação por excelência.

Sem nos aventurarmos muito além nas inferências lingüísticas, por ser esta uma tarefa muito mais exigente em matéria de conhecimentos específicos, e por acreditar que as informações levantadas até aqui são mais do que suficientes para o avanço de nossa construção, passaremos a operar analiticamente num recorte mais específico.

O tema analisado no Capítulo III será, precisamente, a assimilação do conceito de mediação na vertente tecnológica que resultou na origem da expressão Mediação Tecnológica na Educação (MTE).

200 Há, pelo menos, duas linhas de referências interessantes que podemos citar sobre a recursividade. Numa delas, registramos o enfoque tecnológico em busca da semântica: "A psicologia cognitiva contemporânea recorre, muitas vezes, a metáforas de origem técnica, para tentar explicar, apreender ou interpretar a realidade, usando em larga escala modelos computacionais de processamento de dados fornecidos pela informática. O hipertexto, por exemplo, além de ser uma ferramenta da inteligência coletiva, é uma metáfora que pode ajudar a pensar a comunicação, pois seu papel é exatamente o de reunir, não somente textos, mas também redes de associações. As ciências humanas necessitam de uma teoria da comunicação que aborde a significação como elemento central de suas reflexões, no caso, a metáfora do hipertexto pode dar conta da recursividade do sentido, já que ele liga palavras e frases cujos significados remetem-se a outros, num procedimento que reporta à não linearidade discursiva" (MAIO, 2005: 98). Em outro aporte, assinalamos o parecer lingüístico registrando o impacto da tecnologia: “(...) Recursividade semântica - As linguagens de especialidade repercutem-se na estruturação semântica de todo o léxico da língua, re-semantizando lexemas ou grupos de vocábulos e perturbando as relações de significação. Lembramos o exemplo clássico de M. Bréal sobre os valores do termo 'operação', no âmbito do vocabulário médico, militar, financeiro e matemático [Essai de sémantique, 6 ed., Paris, 1924, p.285-86], e acrescentaremos, para sua atualidade, as vicissitudes dos adjetivos ingleses hard e soft ou o substantivo mouse ou window" (VERDELHO, 1998: 11). 
CAPÍTULO III

\section{MTE: A CONSTRUÇÃO DO SIGNIFICADO}




\subsection{Significados construídos, significados a construir}

Uma palavra sem significado é um som vazio, que não faz mais parte da fala humana. (VIGOTSKY, 1999: 06)

Esta é uma boa hora para que nos situemos na trajetória de investigação proposta.

$\mathrm{O}$ esforço gasto até aqui caminhou no sentido de reunir e interpretar indícios que ajudem a construir o conceito da MTE, delimitado como nosso objeto de estudo. Assumindo que se trata de uma tarefa complexa que implica a análise de fenômenos e idéias de largo espectro referenciados em quase todas as áreas das Ciências Sociais, optamos por uma conduta metódica que vai:

(a) do geral para o específico, recortando a partir do sentido geral da Mediação ${ }^{201}$ uma ou mais acepções possíveis que nos ajudem a entender sua natureza enquanto fenômeno social;

(b) do passado para o presente, reconstruindo historicamente os usos e transformações do conceito analisado dentro das diferentes linhas filosófico-sociais nas quais ele se manifesta;

(c) do abstrato para o concreto, procurando extrair das matrizes lingüísticas prováveis (latina, inglesa) as operações mentais que procuram identificar o fato e sua descrição substantiva e verba; e

(d) da fragmentação dos campos do conhecimento - Comunicação e Educação -, dos quais emerge a Educomunicação, para a síntese conceitual que nos interessa: aquela que aproxima ambas as visões na intersecção da MTE.

201 O qual, a julgar pelas discussões apenas esboçadas no capítulo anterior, por si só já mereceria um estudo analítico de dimensões enciclopédicas. 
Nesta última aproximação, a qual concentra nossos interesse e esforços, parece inadiável a apresentação de um marco teórico que entendemos como um provável "elo perdido" na construção que integra as mediações comunicativas e educativas: a abordagem sócio-interacionista de Vigotsky.

Cabe então perguntar:

\section{Por que Vigotsky?}

A primeira parte desta resposta, de certa forma, está dada na introdução desta tese, no tópico que denominamos Vigotsky e Freire: uma ponte epistemológica possível e necessária, no qual aventamos a hipótese de que as idéias do psicólogo bielo-russo dialogam mais proficuamente com as orientações freireanas encampadas pela Educomunicação do que as de outros epistemólogos, os quais, vez por outra, são conclamados para o embasamento pedagógico de projetos educomunicativos.

Essa busca por elementos de apoio em correntes teóricas historicamente consolidadas na educação revela-se uma necessidade particularmente aguda no caso da MTE, já que a utilização responsável e eficiente das tecnologias digitais na escola demanda a presença de "alguém que tenha suficiente conhecimento para monitorar o progresso dos alunos" (SOARES, 1999a: 41).

A pertinência da observação de SOARES identifica, justamente, um possível calcanhar-de-aquiles no corpus conceitual da Educomunicação: o diálogo crítico com as ciências experimentais na educação — principalmente a psicologia experimental e a psicopedagogia.

Lembramos aqui que a origem do conceito de mediação na Comunicação, bastante explorado no capítulo anterior, reside principalmente nas matrizes sociológicas e filosóficas que engendraram a chamada Teoria das Mediações a qual, devido a sua enorme influência, chega a ser promovida a paradigma das mediações, por alguns autores.

Também recordamos que, nos enunciados primeiro e segundo de nossos objetivos (vide Introdução desta tese), manifestamos nossa preocupação em levantar e consolidar não apenas referenciais teóricos, mas subsídios instrumentais que ajudem a incrementar a prática em processos educomunicativos, ou, dito de outra forma: nossa proposta visa orientar os mediadores no exercício da mediação educomunicativa. 
Poderíamos ainda acrescentar que nossa esperança é a de aumentar a qualidade da mediação desenvolvida nos processos educomunicativos, esclarecendo que o valor qualitativo a que nos referimos, mais do que um vago "grau negativo ou positivo de excelência” (HOUAISS, 2007) corresponde, no caso, à “capacidade de atingir o(s) efeito(s) pretendido(s); propriedade, virtude" (idem).

Sendo assim, transparece em nosso texto a suposição tácita de que o modelo metodológico vigotskiano não só é compatível com os pressupostos da Educomunicação ${ }^{202}$ como, ainda, pode oferecer contribuições decisivas para a estruturação filosófica e metodológica desse campo emergente.

Por conta desse posicionamento, julgamos altamente recomendável examinar (tanto quanto possível dentro de um espaço tão reduzido) as linhas gerais - princípios, modelos, conceitos - presentes na obra de Vigotsky, tentando evitar reduzi-la a um catálogo de definições descontextualizadas.

De princípio, identificamos a necessidade de esclarecer, pelo menos, três equívocos bastante disseminados nas leituras da obra do psicólogo soviético .

\subsubsection{Esclarecendo sobre Vigotsky}

Eis uma história ilustrativa: em determinada ocasião (o ano era 2001), finalizávamos ${ }^{203}$ um ciclo temático de formação de professores que durara três meses com encontros semanais de três horas. Apesar do tema do curso em questão referir-se a Discussões Pedagógicas [em TICs], optamos por desenvolver as atividades ${ }^{204}$ em um espaço "digitalmente excluído", isto é, numa escola (até aquele momento) sem computadores, fato que, por si só, já causou bastante celeuma e algumas desistências por parte de professores que esperavam, na verdade, mais um curso "para aprender a usar o Windows e o Word".

202 Os quais, por sua vez, foram alvo de apresentação em nosso capítulo I.

203 O "nós" subentendido na questão representa a equipe de formação docente em "TICs" atuante no NAE-10 da Secretaria Municipal de Educação de São Paulo (ver Glossário na seção final desta tese). O público era composto por diretores e coordenadores pedagógicos da rede pública escolar do município de São Paulo.

204 Basicamente: exposição de temas e problemas ilustrados por textos impressos e audiovisuais, técnicas de dinâmica em grupo, debates mediados e produção coletiva de texto. 
Como era de praxe, o último encontro reservou um momento especial para o preenchimento de um questionário de avaliação geral do curso. A resposta mais aguardada, nesses eventos, era sempre para a pergunta Que sugestão você daria para uma próxima edição deste curso?

Com o tempo, passamos a computar, no grupo de respostas habituais, uma observação que nos fez refletir bastante: "Que o curso seja ministrado por alguém da área pedagógica."

Sem considerar a sugestão como um ataque pessoal ${ }^{205}$, só nos restou examinar a opinião manifesta como compreensível, mas não justificável.

"Compreensível" deve-se ao fato de que a formação pedagógica e a atuação escolar dos outros participantes garantia a eles certa unidade de percepção, algo como uma weltanschaung da Pedagogia ${ }^{206}$. A história desta, como se sabe, começa na passagem dos séculos XVIII-XIX (CAMBI, 1999), o que lhe garante um invejável acervo de referências conceituais e metódicas, as quais, por sua vez, lhe conferem uma autoridade institucional indiscutível quando o assunto é a Educação. Então, compreende-se porque um outsider egresso do mundo da "técnica" ou das artes seja considerado fora da área.

"Não-justificável", pois um exame atento das correntes de pensamento mais influentes na Educação contemporânea revela como origem das idéias, no mais das vezes, estudiosos de outras áreas de conhecimento que não estritamente a Pedagogia. Esse é o caso, por exemplo, de Paulo Freire (bacharel em Direito), Jean Piaget (biologista e psicólogo) e do lingüista e psicólogo Lev S.Vigotsky .

Em relação aos dois últimos mencionados, cabe desfazer uma confusão que alguns ainda alimentam sobre a suposta incompatibilidade entre as teorias cognitivistaconstrutivista (de Jean Piaget) e sócio-interacionista (de Lev Vigotsky) ${ }^{207}$.

Ainda que o próprio Vigotsky tenha se ocupado de fazer críticas aos enfoques iniciais de Piaget ${ }^{208}$ (como quando diz que "as uniformidades de desenvolvimento

205 Relacionado, provavelmente, ao fato do autor desta tese ser o único dos coordenadores atuantes no curso que NÃO era professor da rede pública.

206 "Definida como um campo de conhecimentos que investiga a natureza das finalidades da educação numa determinada sociedade, bem como os meios apropriados para a formação dos indivíduos, tendo em vista prepará-los para as tarefas da vida social" (LIBÂNEO, 1991: 24).

"Tal versão, baseada em leituras superficiais, em alguns casos dogmáticas e em outros simplesmente errôneas, dos textos clássicos e das pesquisas mais recentes, impede uma autêntica confrontação que inclua um exame da natureza das perspectivas e problemas propostos pelos nossos autores" (CASTORINA et al., 1997: 09). 
estabelecidas por Piaget aplicam-se ao meio dado, nas condições em que Piaget realizou seu estudo. Não são leis da natureza, mas sim leis histórica e socialmente determinadas" [VIGOTSKY, 1999: 28]), é indelével o fato de que as idéias do psicólogo suíço contribuíram bastante para o desenvolvimento da própria linha de argumentação de Vigotsky e seus colaboradores. Ele próprio afirma que a psicologia deve muito a Jean Piaget: "Não é exagero afirmar que ele revolucionou o estudo da linguagem e do pensamento das crianças" (op. cit. 11).

Além do mais, é ponto pacífico que aquilo que Vigotsky realmente critica é a dicotomia entre o corpo teórico e as práticas empíricas da psicologia experimental na primeira metade do século XX, um alvo muito mais abrangente que as idéias do pesquisador suíço.

Fato é que, no final do século passado, a popularização acelerada dos microcomputadores nas escolas alertou os educadores mais conscientes para a necessidade de romper com a idéia — pedagogicamente pouco confortável — de lidar com a "máquina de ensinar"209, o que acarretou a busca por embasamento epistemológico em linhas pedagógicas que já houvessem superado o paradigma mecanicista-behaviorista ${ }^{210}$.

Se no meio acadêmico atual os debates apaixonados sobre a suposta oposição Piaget-Vigotsky já conheceram a superação, a tônica da discussão, ao que tudo indica, deslocou-se para a síntese do que ambas as teorias têm a oferecer para o entendimento das questões educativas.

208 Recomendamos a leitura de A teoria de Piaget sobre a linguagem e o pensamento das crianças, prefácio que Vigotsky escreveu para a edição russa dos dois primeiros livros de Piaget. Segundo esclarece nota traduzida da edição inglesa "A crítica de Vigotsky, baseada nas primeiras obras de Piaget, pouco se aplica às formulações posteriores de Piaget no que diz respeito às suas teorias" (HANFMANN \& VANKAR in VIGOTSKY, 1998: 11).

209 A menção se refere menos ao artefato propriamente dito que ao princípio da instrução programada concebido por Burrhus Frederic Skinner (1904-1990). Um bom exemplo da ojeriza dos construcionistas em relação à máquina de ensinar pode ser observado na obra de Seymour Papert: "Na Educação, o acrônimo CAI [Computer Aided Instruction - ou Instrução Auxiliada por Computador] é empregado para o uso plenamente assimilado da tecnologia de computação. CAI refere-se a programar o computador para administrar os tipos de exercícios tradicionalmente aplicados por um professor num quadro-negro, num livro-texto ou numa folha de exercícios. Tal procedimento está tão longe de desafiar as suposições da Escola Tradicional que os críticos com freqüência perguntam se isso realmente faz alguma coisa que justifique o custo dos computadores. Os céticos mais empedernidos descrevem o computador como uma 'ficha de memorização de mil dólares', e o que ele faz eles descrevem como 'teste e mate"' (PAPPERT, 1994: 43).

$210 \quad$ "O software instrucionista não deixa explícito o pensamento do aluno que o utiliza. Para que o professor descubra o que o educando pensa em relação ao tema e possa intervir para provocar reflexões significativas, é preciso que ele acompanhe todos os passos da exploração e questione exaustivamente o aluno." (ALMEIDA, 2000: 26) 
Não estamos afirmando que as duas orientações, com focos e objetivos marcadamente distintos, tenham sido assimiladas uma à outra "num passe de mágica" 211. Pelo contrário, é justamente a identidade no foco e a afinidade de objetivos que nos levam a apontar a pertinência do legado de Vigotsky na compreensão da mediação educomunicativa.

Esse não é o único mal-entendido a dificultar nosso diálogo com as teorias do autor de Pensamento e Linguagem. Aliás, o próprio título dessa obra (de longe seu livro mais conhecido), ou melhor, a tradução que dele se popularizou, reflete uma confusão de natureza lingüística, não isenta das conseqüências de uma interpretação inexata.

Explica-se: a tradução do original russo "Мышление и речь"212 resultou, na tradução anglo-americana de 1934 realizada pelo MIT (MIT Press), em "Thought and Language", posteriormente vertida literalmente para o português. Segundo aponta MOLL (1996), o correto seria grafar discurso:

\begin{abstract}
"A ênfase primária de Vygotsky ao examinar o processo de mediação recaía sobre os sistemas de signos usados na comunicação humana, especificamente no discurso. A esse respeito, é fundamental ter em mente que o objeto de sua análise era a atividade comunicativa humana, ou o discurso, não a linguagem entendida como um sistema de uso abstrato. Esta tem sido uma freqüente fonte de confusão entre os leitores ocidentais, exacerbada pelo uso da palavra linguagem em lugar do termo correto discurso, no título de seu trabalho mais conhecido já publicado em inglês (Vygotsky, 1962). Na terminologia de hoje, seus escritos têm sido chamados de análise do discurso ou pragmática, em lugar de lingüística" (WERTSCH, 1996: 110-111).
\end{abstract}

A diferença entre um e outro enfoque é bastante sensível, dentro de nosso esforço para contextualizar as teorias vigotskianas no campo da Comunicação: enquanto, por “linguagem”, é fácil tomar o código e/ou a estrutura da comunicação, já “discurso" remete a um uso político (e estamos falando de um autor politicamente engajado) pouco detectável

211 "Em Vygotsky, a interação social e o instrumento lingüístico são decisivos para compreender o desenvolvimento cognitivo, enquanto em Piaget, este último é interpretado a partir da experiência com o meio físico, deixando aqueles fatores em um lugar subordinado. Além do mais, o processo de desenvolvimento intelectual, explicado em Piaget pelo mecanismo de equilibração das ações sobre o mundo, precede e coloca limites aos aprendizados, sem que estes possam influir sobre aquele. Ao contrário, para Vygotsky, a aprendizagem interage com o desenvolvimento, produzindo sua abertura nas zonas de desenvolvimento proximal, nas quais as interações sociais e o contexto sociocultural são centrais" (CASTORINA et al., 1997: 12).

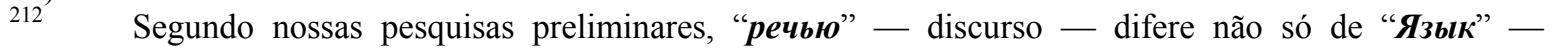
language/linguagem — como também de “слова" ou "слово"- speech/fala ou word/palavra (outras variantes nas traduções anglo-americanas). 
no caso anterior ${ }^{213}$. Talvez para amenizar um pouco a controvérsia, possamos admitir que a expressão possa ter sido empregada nas duas acepções.

Outra confusão semântica envolvendo os escritos de Vigotsky também se relaciona com a tradução e, mais ainda, com o uso do termo mediação:

"Em vários pontos do texto, ao referir-se à estrutura do comportamento, Vygotsky usa um termo que nós traduzimos como 'mediado'. Às vezes esse termo é acompanhado de um desenho mostrando um estímulo, uma resposta e um 'elo de mediação' entre eles [por exemplo, S-X-R ${ }^{214}$ ]. O mesmo termo e virtualmente a mesma forma de representação gráfica foram introduzidos nas teorias norteamericanas de aprendizado nos Estados Unidos no final dos anos 30, tornando-se muito popular nos anos 50, na medida em que foram feitas tentativas de estender as teorias baseadas na associação estímulo-resposta do aprendizado a comportamentos humanos complexos, especialmente a linguagem" (COLE \& SCRIBNER, 1998: 18).

Essa mencionada apropriação indébita do termo e da idéia de "mediação" de Vigotsky, logo após a sua morte, é a provável fonte de várias aplicações metodológicas, no mínimo vagas e, provavelmente, equivocadas.

A dúvida que permanece é: como seria possível que a teoria de um psicólogo que marcou posição justamente apontando a inadequação de modelos mecanicistas para estudar a psique pôde, a posteriori, ser aproveitada como matriz na demonstração de procedimentos behavioristas, isto é, justamente do que ela negava? Ainda segundo COLE \& SCRIBNER,

“É importante ter sempre em mente que Vigotsky não era um adepto da teoria do aprendizado baseada na associação estímulo-resposta e não era sua intenção que a sua idéia de comportamento mediado fosse interpretada nesse contexto. O que ele, de fato, tentou transmitir com essa noção é que, nas formas superiores do comportamento humano, o indivíduo modifica ativamente a situação estimuladora como uma parte do processo de resposta a ela. Foi a totalidade da estrutura dessa atividade produtora do comportamento que Vigotsky tentou descrever como 'mediação'.” (COLE \& SCRIBNER, 1998: 18).

213 Curioso notar que o título da obra capital de Vigotsky revela a influência do lingüista russo Alexander Potebnya (1835-91) que publicou, em 1850, uma obra traduzida como "Pensamento e Linguagem" (BLANCK, 1996: 36).

214 O esquema original do "ato complexo mediado" (que se contrapõe ao modelo "estímulo-resposta") tal como aparece em VIGOTSKY $(1998,53)$ :

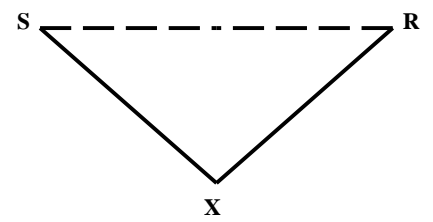


Após esclarecermos alguns pontos considerados essenciais em relação às idéias de Vigotsky, cabe, em nossa opinião, observar as formas pelas quais, para além da afinidade epistemológica "genérica", poderíamos operar com os conceitos que ela desenvolve. Para tanto, julgamos necessário sistematizar essas possíveis contribuições em itens:

I. o sócio-interacionismo vigotskiano constitui uma base epistemológica bastante consolidada, com pressupostos claros e centrada na mediação ${ }^{215}$. Isto, sem falarmos em sua grande disseminação enquanto hipótese de trabalho no âmbito da Pedagogia. Os discípulos de Vigotsky, principalmente Alexander R. Luria (1902-1977) e Alexis N. Leontiev (1903-1979) asseguraram a continuidade, a sistematização e a difusão do pensamento de seu jovem mestre. Existe, portanto, material de pesquisa abundante e disponível - registros, relatórios e interpretações psicológicas de experimentos, referentes ao desenvolvimento infantil, distúrbios da comunicação e análises culturais de comunidades lingüísticas, que podem servir como referências históricas e metodológicas interessantes para a Educomunicação;

\section{II. o modelo de mediação ou, mais precisamente, de MTE que buscamos} delinear, deve contemplar aspectos referentes tanto aos processos comunicativos, quanto aos educativos. Neste ponto, reconhecemos na leitura de Vigotsky uma preocupação comum com o que, hoje, a partir de Soares, entendemos por Educomunicação: ambas as correntes colocam a centralidade do desenvolvimento na atividade relacional entre os seres humanos, referenciados pelo repertório de saberes que entendemos como "Cultura",216 em seu sentido mais abrangente;

215 “É um axioma para a psicologia científica que a compreensão entre as mentes é impossível sem alguma expressão mediadora. $\mathrm{Na}$ ausência de um sistema de sinais, quer lingüístico, quer outro, é apenas possível o tipo mais primitivo e limitado de comunicação. A comunicação através de movimentos expressivos, observados principalmente entre os animais, não é tanto uma comunicação mas sim a propagação de uma disposição mental [...] A transmissão racional, intencional, de uma experiência e de um pensamento a outros requer um sistema mediador cujo protótipo é o discurso humano" (VIGOTSKY, 1962:6 in SPERBER \& WILSON, 2001: 33).”

$216 \quad$ "O aspecto 'cultural' da teoria de Vigotsky envolve os meios socialmente estruturados pelos quais a sociedade organiza os tipos de tarefas que a criança em crescimento enfrenta, e os tipos de instrumentos, tanto mentais quanto físicos, de que a criança dispõe para dominar aquelas tarefas. Um dos instrumentos básicos 


\section{III. o papel do mediador no processo educomunicativo está diretamente} relacionado com o modelo de mediação no qual ele baseia seu trabalho.

Nossa questão principal passa a ser o delineamento de um modelo para a mediação, pois, numa dinâmica em que o modelo não é explicitado e assumido $^{217}$, fica muito difícil definir os objetivos da ação educomunicativa e avaliar se eles foram efetivamente alcançados. Acreditamos poder integrar as contribuições de Vigotsky aos aportes teóricos relacionados no capítulo II oriundos, principalmente, das diferentes leituras da teoria das mediações para delinear o mencionado modelo.

\section{IV. a base para o modelo de mediação que propomos neste capítulo é o conceito} de Zona de Desenvolvimento Proximal (ZDP), um construto teórico apresentado por Vigotsky para explicar a disparidade entre os níveis de desenvolvimento cognitivo demonstrados por crianças da mesma idade em testes de resolução de problemas. Segundo ele, ZDP

“é a distância entre o nível de desenvolvimento real, que se costuma determinar através da solução independente de problemas, e o nível de desenvolvimento potencial, determinado através da solução de problemas sob a orientação de um adulto ou em colaboração com companheiros mais capazes" (VIGOTSKY, 1998: 112).

Além de sua própria definição, contamos com o auxílio de várias interpretações complementares oriundas de pesquisadores que se debruçaram sobre esse conceito. Assim, TUDGE (1996) esclarece que

\footnotetext{
"Vygotsky também deixou indícios de uma visão aparentemente teleológica do processo evolutivo, um processo no qual as crianças vêm a ser socializadas na cultura dominante. Assim como Marx escreveu que o primeiro uso de instrumentos mediou a experiência dos seres humanos no ambiente físico, exercendo um imenso impacto sobre as relações sociais entre as pessoas, Vygotsky usou a noção de 'instrumentos psicológicos' para explicar a revolução evolutiva dos processos 'naturais' até processos mentais mais elevados. Portanto, a linguagem, instrumento de imenso poder, assegura que significados lingüisticamente criados sejam significados compartilhados, significados sociais" (TUDGE, 1996: 153).
}

inventados pela humanidade é a linguagem, e Vigotsky deu ênfase especial ao papel da linguagem na organização e desenvolvimento dos procesos de pensamento" (LURIA, 2001: 26).

${ }_{217}$ A nosso ver, não podemos falar em "inexistência de modelo", apenas em desconhecimento do modelo adotado ou ainda em "inadequação do modelo". 
Podemos acrescentar a leitura de McNAMEE (1996) sobre as duas condições necessárias para se provocar mudanças em uma ZDP:

"A primeira é a capacidade de brincar ${ }^{218}$, a capacidade de imaginar. Vygotsky diz que o jogo guia uma ZDP. Ele queria dizer que, para crescerem e se desenvolverem, as pessoas precisam ser capazes de pensar acerca de si mesmas de uma forma que seria diferente daquela que elas são agora. (...) A segunda condição para a mudança em uma ZDP é a capacidade de fazer uso da ajuda dos outros [BRUNER, 1962] $]^{219}$, a capacidade de se beneficiar da troca de experiências e de conversações com os outros" (McNAMEE, 1996: 280).

\section{V. de uma forma indissociável do conceito de ZDP, há alguns termos do} pensamento vigotskiano - que representam diferentes aspectos do seu processo de mediação - com os quais devemos nos familiarizar:

a. atividade prática ou "externa" que seria, segundo COLE (1996), uma idéia tomada de Hegel por intermédio de Marx e Engels, que equivale à "unidade básica para o estudo dos processos psicológicos" (COLE, 1996: 87);

b. interiorização ou internalização de conceitos, considerada um dos pontos sensíveis na contraposição entre os postulados de Piaget e os de Vigotsky, refere-se à "reconstrução interna de uma operação externa" ${ }^{220}$, isto é, a incorporação no sistema mental do

218 No capítulo 7 da edição brasileira de A Formação Social da Mente, denominado "O papel do brinquedo no desenvolvimento", encontram-se as idéias nas quais a autora provavelmente se baseou para emitir suas afirmações. No contexto, as palavras "brinquedo" e "jogo" são utilizadas como sinônimo.

${ }_{219}$ A autora menciona a introdução de Jerome S. Bruner para a edição americana de 1961 de Thought and Language de Vigotsky.

220 O texto prossegue com o exemplo do gesto de apontar: "A criança tenta pegar um objeto colocado além de seu alcance: suas mãos, esticadas em direção àquele objeto, permanecem paradas no ar. Seus dedos fazem movimentos que lembram o pegar. Nesse estágio inicial, o apontar é representado pelo movimento da criança, movimento este que faz parecer que a criança está apontando um objeto - nada mais que isso. Quando a mãe vem em ajuda da criança, e nota que o seu movimento indica alguma coisa, a situação muda fundamentalmente. $\mathrm{O}$ apontar torna-se um gesto para os outros. A tentativa malsucedida da criança engendra uma reação, não do objeto que ela procura, mas de uma outra pessoa. Conseqüentemente, o significado primário daquele movimento malsucedido de pegar é estabelecido por outros. Somente mais tarde, quando a criança pode associar seu movimento à situação objetiva como um todo, é que ela, de fato, começa a compreender esse movimento como um gesto de apontar. Nesse momento, ocorre uma mudança naquela função do movimento: de um movimento orientado pelo objeto, torna-se um movimento dirigido para uma 
educando de conceito socialmente adquirido por meio da vivência/experimentação de uma atividade prática. Esse estágio operativo compõe uma relação triádica, integrada ainda pela “automatização" e pela "fossilização" da capacidade desenvolvida;

c. mudança, a qual, "no contexto da zona de desenvolvimento proximal, é via de regra, caracterizada como uma mudança individual, na qual a criança pode hoje realizar sozinha alguma coisa que ontem realizaria apenas com assistência" (MOLL, 1996: 14). Em nosso ponto de vista, trata-se de um conceito fortemente associado com o protagonismo da criança e do jovem, um pressuposto anunciado dentro das ações educomunicativas ${ }^{221}$;

d. níveis de desenvolvimento ou fontes de história, os quais seriam, segundo a teoria sócio-histórica-social, os âmbitos em que se pode verificar o desenvolvimento humano, a saber: (1) nível filogenético ou desenvolvimento das espécies; (2) nível histórico ou desenvolvimento da espécie humana (Homo Sapiens); (3) nível ontogenético ou desenvolvimento individual da criança; e (4) nível microgenético ou desenvolvimento de processos que transcorrem dentro de uma interação psicológica única, como uma sessão de trabalho ou experimento (COLE, 1996: 88).

outra pessoa, um meio de estabelecer relações" (VIGOTSKY, 1998: 112). Acreditamos que esta longa transcrição vale, também, como um exemplo de mediação, representado na ação da mãe solícita.

${ }_{221} 2$ "As crianças têm sido contraditoriamente vistas como agentes $e$ como objetos do processo educacional. Elas são agentes porque elaboram internamente a atividade pedagógica. Essa elaboração pode, ou não, ter muita relação com os contextos no plano pedagógico. As crianças são também concebidas como objetos, ou como receptores de instrução. A pedagogia tem operado, usualmente, sobre a suposição de que as crianças são 'receptoras' da instrução e não, como elas certamente são, elaboradoras dos conteúdos apresentados a elas [Vygotsky, 1978]" (BLANCK, 1996: 48). 


\section{VI. a estrutura propriamente dita da ZDP pode ser descrita, segundo GALLIMORE \& TARP (1996, ver gráfico 01), como um processo de quatro estágios sucessivos, assim caracterizados:}

a. estágio I - o desempenho é assistido por indivíduos mais capazes, que pode ter como mediadores os docentes, pais ou os próprios pares envolvidos no processo educativo;

b. estágio II - o desempenho é auto-assistido, e manifesta-se no discurso autodirigido da criança ${ }^{222}$ que se perpetua no adulto;

c. estágio III - o desempenho é desenvolvido, automatizado e fossilizado, dispensando o auxílio da assistência externa e da auto-assistência; e

d. estágio IV - a automatização do desempenho conduz a um retorno à zona de desenvolvimento proximal, retomando o ciclo que leva ao desenvolvimento das novas capacidades, numa espécie de moto-contínuo da aprendizagem..

222 Piaget colocaria aqui o conceito da fala egocêntrica, um ponto que será criticado por Vigotsky (1999). Poderíamos também nos lembrar do princípio da automediação em Hegel (ver capítulo II desta tese). 


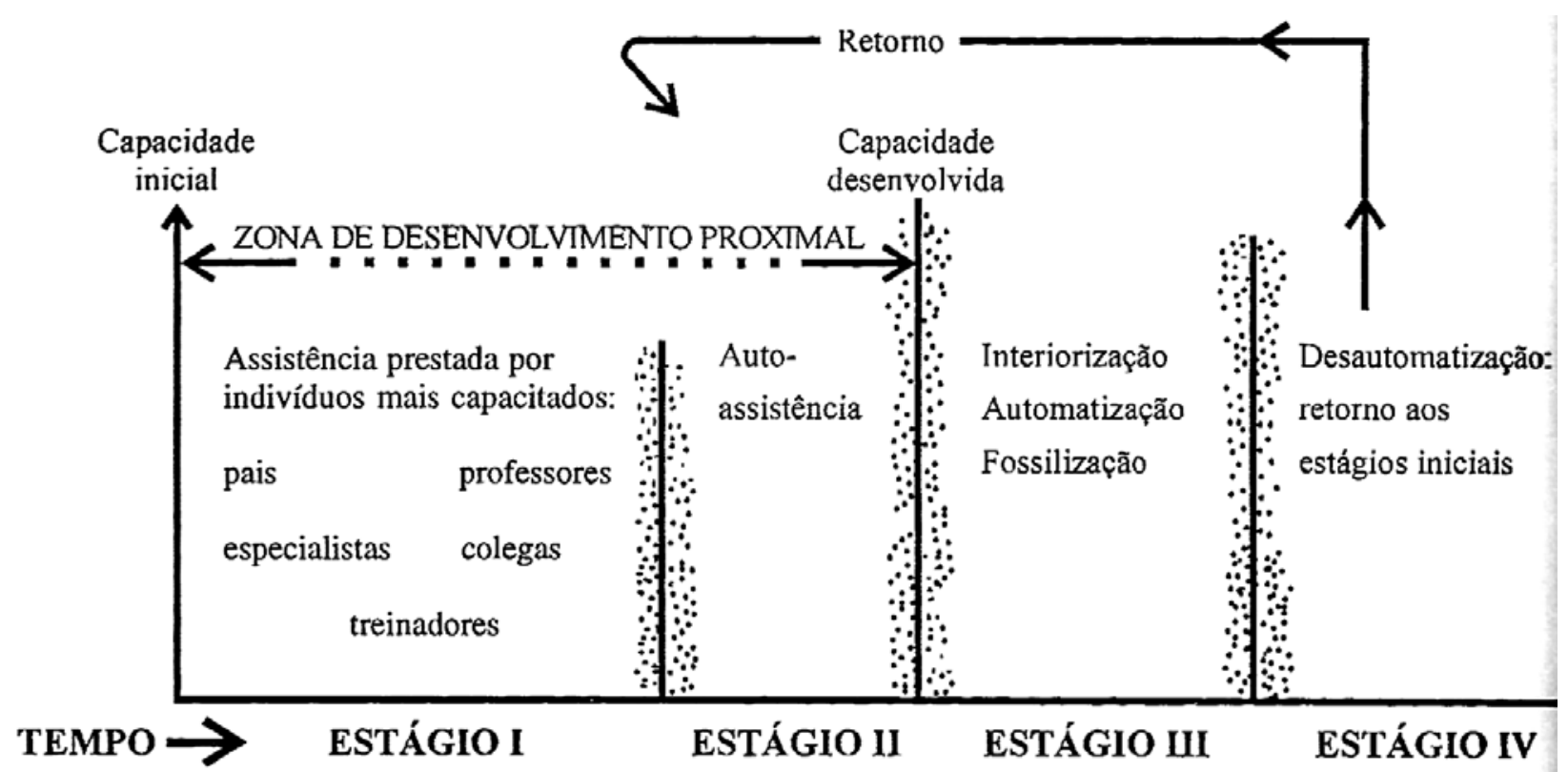

Gráfico 01: Modelo de ZDP de quatro estágios (GALLIMORE \& TARP, 1996: 180)

Complementando esta linha de abordagens e levando em conta a seqüência de ações encadeadas que apresentamos logo na abertura deste capítulo (numeradas de "a" a "d"), julgamos pertinente recorrer a um enfoque alternativo, que vem a ser o uso de modelos visuais (ou gráficos) para representar o processo da mediação ${ }^{223}$.

Tal recurso, imaginamos, pode complementar e consolidar nosso entendimento da questão mediativa, orientando-nos para a necessária aplicação do conceito $^{224}$ à especificidade da MTE. Ou seja: esperamos obter, desta maneira, operações analíticas e instrumentais mais delimitadas, tais como tipificação, categorização, comparação qualitativa e outras que são próprias da metodologia dialética que nos inspira.

223 "Os sistemas de representações têm por finalidade semiotizar, ou seja, estruturar linguagem, sensação e memória em códigos que traduzam nossa apreensão do real. Desse modo, a capacidade humana de pensar por meio de metáforas, simulando o mundo através de modelos mentais, justifica-se em função das habilidades de manipulação e imaginação dos indivíduos" (MAIO, 2005: 108).

224 "Uma análise histórica e dialética, portanto, seria aquela que alcançaria a essência dos fenômenos, revelando-os como inter-relacionados com outros fenômenos com os quais e a partir dos quais constituem totalidades dinâmicas" (CARVALHO et al, 2000: 48). 
No capítulo anterior, recorremos sistematicamente à descrição de idéias — algumas com certo grau de complexidade e abstração - de vários investigadores que se debruçaram sobre a mediação, geralmente como um conceito fundante. Acreditamos que esse procedimento analítico-expositivo pede um contraponto gráfico-esquemático, cuja "concretude", baseada em modelos de lógica visual, sirva para estabelecer uma ponte epistemológica com o universo de aplicação da MTE.

Também pretendemos — ampliando o âmbito de nossas contribuições — que a esquematização torne mais claros os mecanismos analisados, primeiramente para nós mesmos e, extensivamente, para os leitores mais familiarizados com raciocínios graficamente representados do que com a discussão filosófica de questões de fundo.

Finalizando esta justificativa, cabe lembrar que o uso de diagramas, esquemas relacionais, fluxogramas e outras formas de representação gráfica ocorre com bastante freqüência nos tópicos teóricos da Comunicação e, talvez de maneira um pouco mais parcimoniosa, também na Educação ${ }^{225}$.

Note-se que vários dos modelos apresentados nas próximas páginas são oriundos de autores tanto do âmbito da educação quanto do campo da comunicação, sendo que nossa intenção é desenvolver um modelo próprio que agregue os dois tipos de contribuição e seja, ao final, correspondente à representação das dinâmicas identificadas com a MTE.

225 Nas últimas décadas, a disseminação crescente dos chamados "mapas conceituais" (AUSUBEL, 2003; NOVAK, 1996) ameaça inverter essa tendência. Segundo MOREIRA (2007): "De um modo geral, mapas conceituais, ou mapas de conceitos, são apenas diagramas indicando relações entre conceitos, ou entre palavras que usamos para representar conceitos." 


\subsection{Modelos visuais para entender a Mediação}

Apresentaremos, nas próximas páginas, três ordens de modelos de mediação graficamente representados :

(1) modelo elementar ou protomodelo, construído com a finalidade de entender a evolução e as diferentes possibilidades do conceito a partir da composição e combinação de elementos simples;

(2) modelos comunicacionais, transcritos e analisados a partir do corpus epistemológico da Comunicação, aqui representados pelo Modelo Matemático (SHANNON \& WEAVER, 1949) e pelo Processo da Comunicação Humana (BORDENAVE, 1983); e

(3) modelos educacionais, transcritos e analisados a partir do corpus epistemológico da Educação, aqui representados pelo já conhecido Modelo de ZDP em Quatro Estágios (GALLIMORE \& TARP, 1996) e pelos Esquemas de Midiação/Mediatização dos Processos de Formação (ALAVA, 2002). 


\subsubsection{Modelo Gráfico Elementar}

Voltaremos, uma vez mais, a nos apoiar no léxico para estabelecermos este esquema em seu formato inicial, ao qual chamamos de protomodelo. Tomemos o verbete abaixo transcrito de outra fonte léxica consagrada na Língua Portuguesa:

MEDIAÇÃ̃: S.F. - (3) Relação que se estabelece entre duas coisas, ou pessoas, ou conceitos, etc., por meio de uma terceira coisa, ou pessoa, ou conceito, etc. ${ }^{226}$

quadro 22: definição alternativa de "mediação" (DE HOLLANDA: 1999)

Com base nessa definição, tomemos o gráfico 02 :

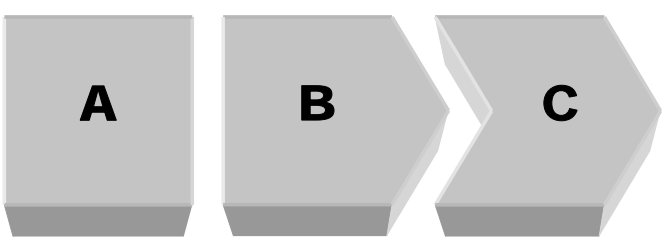

gráfico 02: combinação organizada de elementos díspares

Podemos entender que "B" é o elemento que medeia "A" e "C", raciocínio que faz sentido se "mediar" for entendido na acepção que consta no quadro 22 - isto é, num sentido estritamente organizativo e combinatório - e em nenhuma outra. A afirmação é correta neste nível de entendimento.

Mas quando afirmamos que $\mathbf{B}$ faz a mediação ou usamos o verbo mediar na forma ativa, incorremos num erro, pois $\mathbf{B}$ apenas se encontra entre $\mathbf{A}$ e $\mathbf{C}$, o que corresponde a um estado e não a uma atividade.

Avançando um degrau em nosso raciocínio, passemos a considerar A, B e C como elementos ativos em uma relação. Isto quer dizer que, além da existência individual e suas implicações (identidade, autonomia, propriocepção, etc.), consideraremos que eles possuem iniciativa e determinação para interagirem entre si.

226 Dicionário Eletrônico Aurélio Século XXI. Rio de Janeiro: Editora Nova Fronteira, 1999 — a idéia é oferecer uma alternativa complementar a nosso referencial básico empregado até aqui (HOUAISS, 2007). 
Vamos agora supor que $\mathbf{A}$ e $\mathbf{C}$ são elementos isolados por um fator qualquer que seja: distância física ou temporal, incompatibilidade mútua — parcial, mas não total ${ }^{227}$-, que traduzimos, visualmente, pelo desenho das arestas que não se encaixam (gráfico 03).

Assumiremos, no entanto, que $\mathbf{A}$ e $\mathbf{C}-$ dado que sua incompatibilidade é apenas parcial $^{228}$ — são elementos passíveis de mediação, isto é elementos mediados em potencial. Podemos acrescentar a ilação de que A, B e C são também elementos mediadores em potencial, isto é, seu papel não está pré-determinado à passividade na relação mediada.

Nesse caso porém, ainda que exista, a disposição de um ou de outro para a interação mútua revela-se insuficiente para o estabelecimento de uma dinâmica entre os dois elementos ou uma integração maior de qualquer natureza.
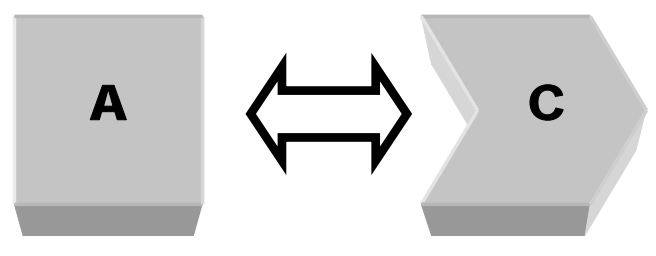

gráfico 03: incompatibilidade na relação entre dois elementos

Em nossa hipotética "equação espacial" - a qual lida com um mínimo de abstração, a ponto de ser cabível apresentá-la a uma criança (por conta de sua concretude "piagetiana") — vamos introduzir agora o elemento $\mathbf{B}$ :

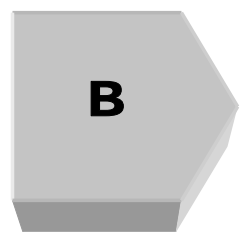

gráfico 04: elemento isolado

227 Esta será nossa hipótese de trabalho, por falta de base histórica, epistemológica ou etimológica para discorrer sobre mediação em caso de incompatibilidade total dos elementos envolvidos.

228 Podemos presumir que ela seja provisória, ou melhor: circunstancial. 
Agora temos o elemento B, o qual, por algum motivo, está vinculado aos elementos A e C (notemos suas arestas), os quais, como observamos antes, entre si não se vinculam. Assumiremos que B, devido a suas características circunstancialmente privilegiadas, representará o papel de mediador ativo na relação:
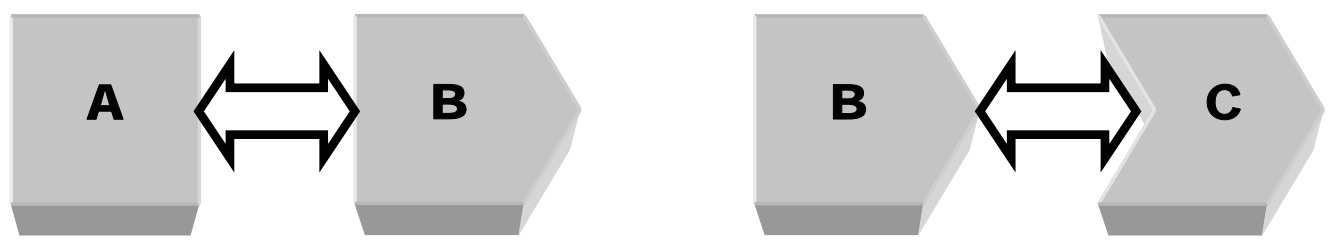

gráfico 05: relações compatíveis de elementos isolados parcialmente díspares

Pois bem, a disposição (no sentido de diligência ou iniciativa) de $\mathbf{B}$ faz com que ele procure aproximar A e C, e sua dupla compatibilidade ${ }^{229}$ o permite.

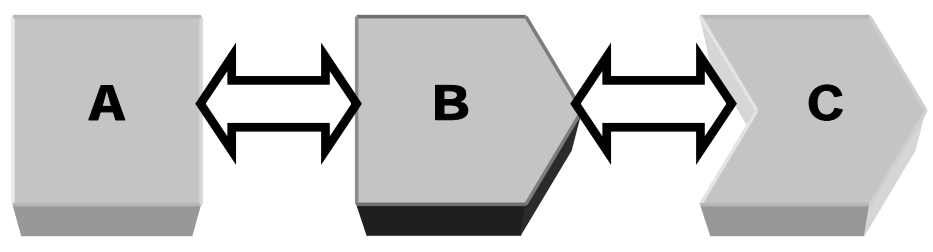

gráfico 06: relação mediada destacando o mediador ativo

Então, torna-se possível interligar A e C por meio da intervenção de B, o que nos permite afirmar, sem grande risco de errarmos, que B, efetivamente, faz a mediação entre A e C.

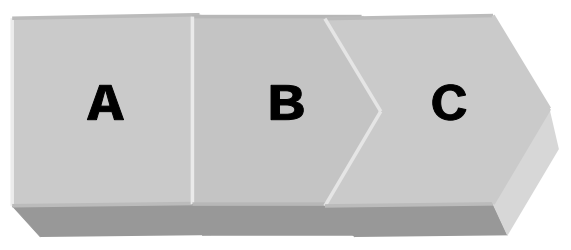

\section{gráfico 07: agrupamento sinérgico como resultado da mediação}

229 E, é claro, a anuência de A e C, que pode existir num grau maior ou menor, mas sempre suficiente. 
É claro que essa construção abre mão da complexidade inerente ao nosso objeto de estudo. Por isso, nós a consideraremos, por ora, um protomodelo.

Conforme veremos, na seqüência, os elementos circunscritos à abordagem cultural tem uma permeabilidade e uma topologia muito diferentes dos nossos "blocos de montar" do protomodelo. Ainda assim, queremos assinalar algumas leituras deste breve exercício imaginativo que consideramos significativas a ponto de serem utilizadas na análise dos modelos mais complexos:

(1) a interação entre individualidades (gráficos 05, 06 e 07) só é possível entre agentes - elementos que participem ativamente da ação. Nesse sentido, elementos mediados equivalem a elementos mediadores, ainda que considerados pela perspectiva de um exercício menor de seu protagonismo ${ }^{230}$;

(2) a interação entre agentes díspares ${ }^{231}$ pode ser estabelecida por (“depende de" é uma afirmação condicionada ao grau de motivação/necessidade da interação ${ }^{232}$ ) um agente mediador mais ou menos consciente dos processos envolvidos nessa mediação. Referimo-nos a ele anteriormente como "mediador ativo" e asseveramos que nãa se trata de um princípio ôntico, mas de um papel que é desempenhado no contexto da mediação específica;

(3) em nossa esquematização, tal interação intencional (volitiva) é identificada com a figura da seta “ $\Leftrightarrow$ ” que representa o esforço de mediação. Para demonstrar seu caráter mais significativo - evidenciando o sentido, a intensidade e a bidirecionalidade da interação mediativa —, nós denominaremos essa interação volitiva $^{233}$, daqui para diante, de fluxo mediatório;

230 Convém lembrar que o protagonismo de B só existe no contexto do processo mediatório dentro do qual ele é referido como mediador ativo. Fora dessa relação, ele tem o significado de um "elemento isolado" (gráfico 04).

$231 \quad$ Ver gráficos 05 e 06.

232 Sem falarmos na questão da simetria na relação, já que o verbo "depender" denota uma relação de poder implícita (hierarquia).

${ }_{233}$ Ou talvez, do ponto de vista dos sujeitos, ela seja a vontade interativa (desejo ou afã pela interação). 
(4) o esforço de mediação e, por conseqüência, a qualidade do fluxo mediatório implica na existência, para tanto, de:

a. disponibilidade ${ }^{234}$ dos agentes para a mediação;

b. afinidade, ainda que parcial, do agente mediador com os agentes mediados; $\mathrm{e}$

c. sinergia $^{235}$ do conjunto de elementos orientada pelo interesse e para os resultados da mediação;

(5) a mediação resulta, ao final, em uma interação volitiva exercida por um conjunto de elementos-agentes que passam a constituir uma nova unidade em ação (gráfico 07), numa relação que pode ser descrita como sinérgica ${ }^{236}$. Notemos que esta unidade só existe no tempo e em função da mediação, o que não impede que ela enquanto processo de transformação da realidade - seja modificada, restaurada, repetida, replicada ou expandida sempre que a mesma volição se repetir em contexto semelhante.

234 Na acepção de "potência", "capacidade" e também de "disposição".

235 Como "[Rubrica-sociologia.]: coesão dos membros de um grupo ou coletividade em prol de um objetivo comum" (HOUAISS, 2007).

236 No sentido lato "(2) ação ou esforço simultâneos; cooperação, coesão; trabalho ou operação associados" ou, no sociológico "(5) coesão dos membros de um grupo ou coletividade em prol de um objetivo comum", ambos extraídos de HOUAISS (2007). Interessante notar como o termo se popularizou, com certo excesso, nesta década, no meio corporativo/empresarial. Etimologicamente, a palavra se origina do francês synergie (raiz no grego: synergía). 


\subsubsection{Modelos Gráficos Culturais}

\subsubsection{O modelo matemático de comunicação}

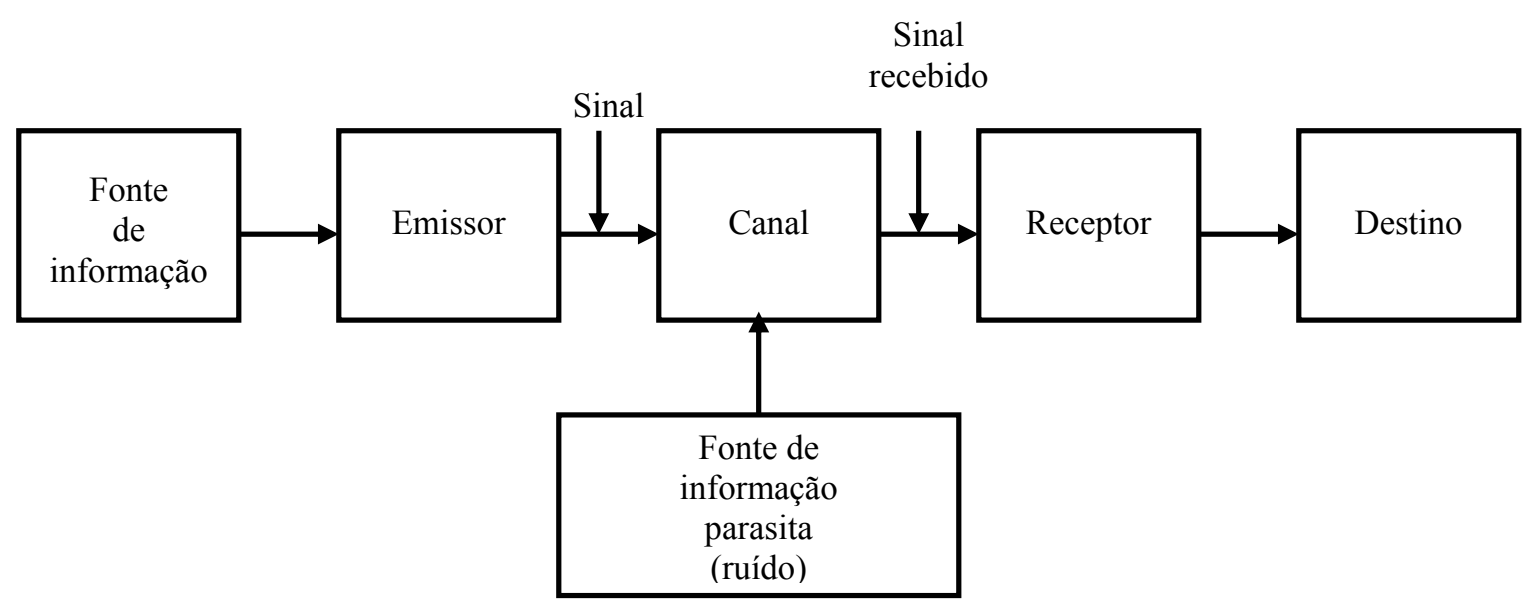

gráfico 08: modelo matemático de comunicação de SHANNON \& WEAVER (1949)

O modelo representado no gráfico $08^{237}$ foi proposto por Claude Shannon (19162001), popularizado por Warren Weaver (1894-1978) ${ }^{238}$ e adotado por estudiosos da Informação na chamada corrente cibernética e dos comunicólogos funcionalistas. Não obstante, ele ocorre ainda em demonstrações corriqueiras nas sub-áreas do marketing e da publicidade, principalmente em explanações de nível técnico.

Já à primeira vista, é evidente que não se trata de um modelo de relação mediatória, já que o fluxo informacional caminha unidirecionalmente da fonte ao destino. Aos agentes no processo - emissor e receptor - também se atribui um papel bastante delimitado e limitado, trabalhando em função da estrutura pré-concebida. O mais interessante é que esse modelo "clássico" simplesmente dispensa ou ignora totalmente o processo da mediação e, conseqüentemente, o papel do mediador, substituindo o elo de (inter)mediação entre os agentes pela entidade indefinida e impessoal do "Canal".

\footnotetext{
237 Transcrito de GUINSLAIN (1994).

238 Em alguns contextos, a concepção do modelo é atribuída em conjunto ao engenheiro e matemático SHANNON - considerado como o fundador da Teoria da Informação — e o também matemático WEAVER. Isso não procede, visto que o segundo apenas traduziu o modelo do primeiro em termos acessíveis aos não-especialistas.
} 
Sobre o modelo em questão, GUINSLAIN afirma que

\begin{abstract}
“... se se admitisse o modelo de SHANNON e WEAVER como uma explicação satisfatória do fenômeno da comunicação, dever-se-ia pensar que tudo o que foi dito ou mostrado numa classe, fora efetivamente ouvido ou compreendido por todos os participantes, o que está longe de ser o caso" (GUINSLAIN, 1994: 172).
\end{abstract}

Ainda segundo o mesmo autor, faltam, no modelo, o conceito de feedback (retroalimentação), da interpretação/compreensão dos sinais, e dos efeitos das mensagens sobre os destinatários. Essas lacunas seriam preenchidas, e tais adendos acabariam sendo incorporados pela cibernética em revisões subseqüentes do modelo ${ }^{239}$.

Podemos tomar este modelo como referência por sua antinomia com o modelo comunicacional mediado que chamamos há pouco de protomodelo. Grosso modo, poderíamos dizer que a oposição entre os princípios que orientam a visão de um modelo e de outro reside em que

(a) no protomodelo, as condições — alcance, eficiência, qualidade - da comunicação são definidas pelos agentes, pelo processo e, em última análise, pela interação dinamicamente construída entre eles (agente/agente e agente/processo);

(b) no modelo matemático, as condições da comunicação são definidas $a$ priori pela eficácia da transmissão, sem levar em conta outra contribuição dos agentes que não a preservação do sinal.

Entretanto, a influência do modelo matemático não deve ser subestimada, já que ela serviu de base para diversas concepções que nortearam o uso das TICs na educação. Podemos dizer que o problema maior ligado ao modelo matemático não diz respeito a ele em si - objeto de arqueologia cultural que é, tanto para a Comunicação quanto para a Educação - , mas o que dele permanece vivo nas teorias que o sucederam.

Passaremos agora a análise de um modelo de Comunicação bastante distinto. 


\subsubsection{O processo de comunicação humana de Bordenave}

O paraguaio Juan E. Diaz Bordenave é um pioneiro na pesquisa das inter-relações entre Comunicação e Educação, apresentando, ao longo de sua extensa carreira, alguns paralelos com a trajetória do educador Paulo Freire, por conta, principalmente, de sua atuação junto à educação em comunidades rurais. Além de uma obra significativa, que formou gerações de estudantes de Comunicação e que ainda hoje é lida (principalmente pela acessibilidade de seu discurso), ele chegou a postular, numa seqüência de etapas, um modelo para entendimento da comunicação humana. Vejamos o gráfico $09^{240}$ :

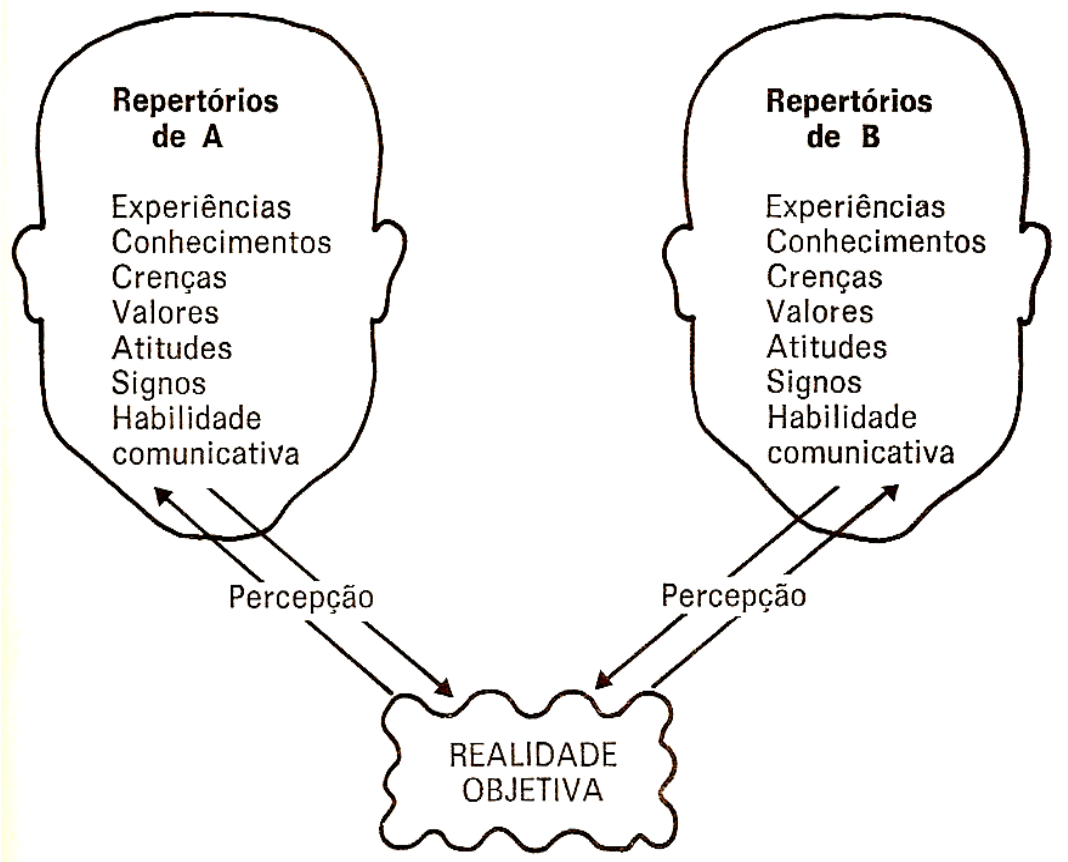

gráfico 09: percepção da realidade segundo BORDENAVE (1983)

240 Este e outros quadros produzidos pelo autor foram transportados direto das páginas de seu livro Além dos Meios e Mensagens (1983). 
O primeiro estágio da teorização de Bordenave parte da percepção e nos informa que os indivíduos A e B relacionam-se com a Realidade Objetiva através de sua percepção, mas que é impossível que a percebam da mesma maneira "Porque a dinâmica mental de $A$ e $B$ consta de repertórios diferentes de experiências, conhecimentos, crenças, valores, atitudes" (BORDENAVE, 1983: 16). As diferenças de percepção são acentuadas mentalmente - pelos diferentes repertórios de signos - e fisicamente - pela maior ou menor acuidade sensorial de cada um dos envolvidos.

Aí identificamos um "estágio hegeliano" de tratamento da mediação (ainda que Bordenave não se refira ela nesses termos), pois está implícita a idéia de uma realidade mediada. O passo seguinte conduzirá à produção de significados, ou seja, de uma construção ativa de conceitos a partir da comparação entre o repertório interior e os estímulos externos oriundos da percepção (gráfico 10).

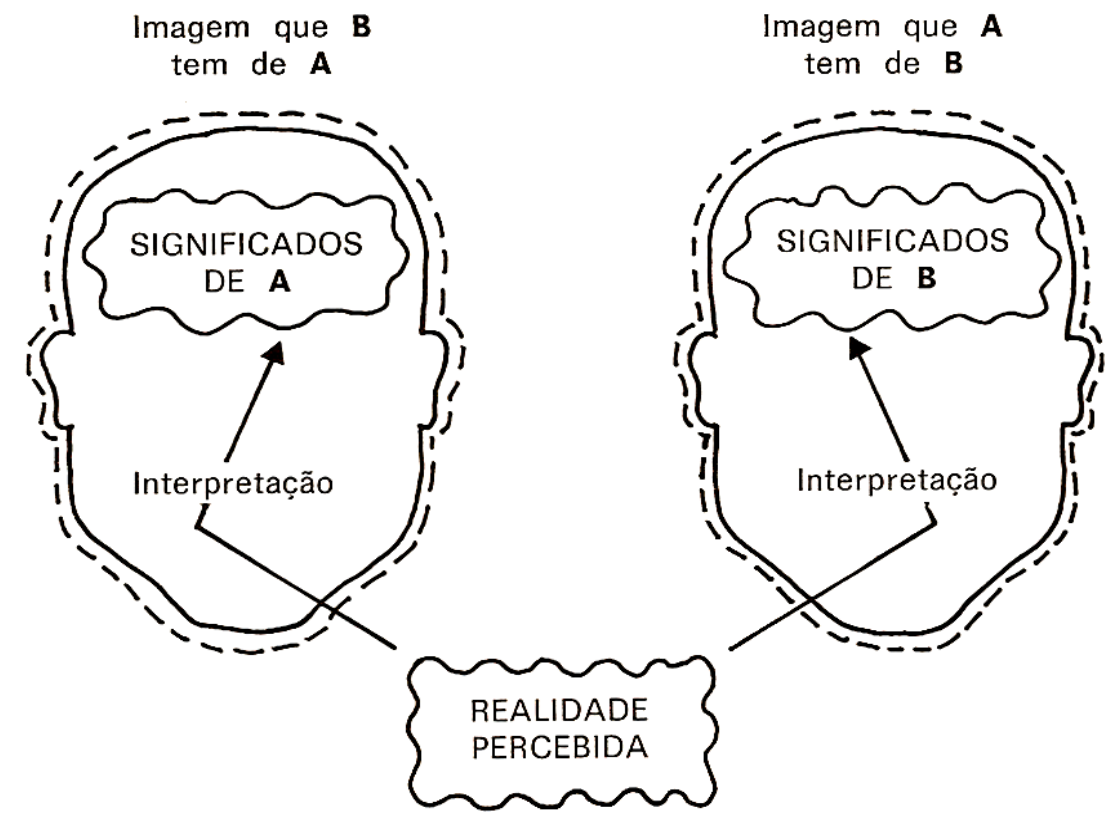

gráfico 10: interpretação da realidade segundo BORDENAVE (1983)

Note-se que ainda não verificamos uma real interação entre $\mathrm{A}$ e $\mathrm{B}$, já que os elementos da mediação não demonstraram ainda um real impulso para interagirem. Isto acontecerá no passo seguinte (gráfico 11): 


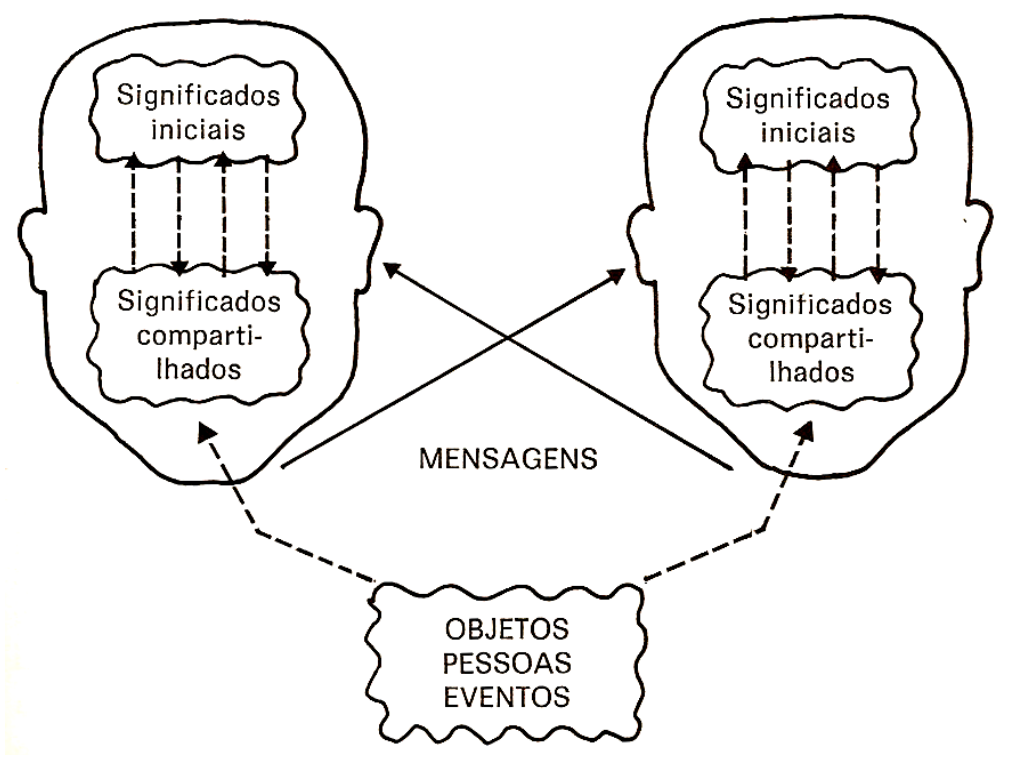

gráfico 11: compartilhamento de significados na comunicação BORDENAVE (1983)

A partir do momento em que ocorre um processo ativo de comunicação entre $\mathbf{A}$ e $\mathbf{B}$, entendemos o compartilhamento de significados entre $\mathbf{A}$ e $\mathbf{B}$, identificando o que poderia ser chamado de uma "mediação simétrica", ou mediação entre pares, referida tanto em Paulo Freire ${ }^{241}$ — falando da educação de adultos — quanto na abordagem Vigotskiana ${ }^{242}$ — quando infere a gênese dos conceitos nas crianças.

Entretanto, uma expressão mais exata da aproximação entre a Comunicação Humana de Bordenave e nosso modelo mediativo, ainda em construção, pode ser visualizada no gráfico 11. Nele, o autor paraguaio adentra os conceitos iniciais da semiótica, traduzindo em termos simples o conceito da mediação cultural por meio dos signos ou, mais propriamente, a mediação semiótica, de forma muito semelhante àquela descrita por Vigotsky ${ }^{243}$.

\footnotetext{
241 "Ninguém educa ninguém, ninguém educa a si mesmo, os homens se educam entre si, mediatizados pelo mundo" (FREIRE, 1987: 68). De longe sua passagem mais ilustre.

242 "A mediação do outro desperta na mente da criança um sistema de processos complexos de compreensão ativa e responsiva, sujeitos às experiências e habilidades que ela já domina. Mesmo que ela não elabore ou não apreenda conceitualmente a palavra do adulto, é na margem dessas palavras que passa a organizar seu processo de elaboração mental, seja para assumi-las ou para recusá-las" (FONTANA, 2005:19).

243 "A potencialidade para as operações complexas com signos já existe nos estágios mais precoces do desenvolvimento individual. Entretanto, as observações mostram que entre o nível inicial (comportamento elementar) e os níveis superiores (formas mediadas de comportamento) existem muitos sistemas psicológicos de transição. Na história do comportamento, esses sistemas de transição estão entre o biologicamente dado e o culturalmente adquirido. Referimo-nos a esse processo como a história natural do signo" (VIGOTSKY, 1998: 61).
} 


\subsubsection{A ZDP e a dupla natureza da mediação}

Por um momento, voltemos ao modelo apresentado no gráfico 01 , correspondente à dinâmica do processo de desenvolvimento de conceitos na Zona de Desenvolvimento Proximal (ZDP) como representada por GALLIMORE \& THARP (1996). Recordemos que se trata de um modelo estilo "linha do tempo" dividido em quatro estágios sucessivos (I a IV).

Os estágios I e II constituem os "estágios iniciais" que marcam a transição entre a fase na qual a criança ${ }^{244}$ ainda necessita de auxílio exterior para alcançar o domínio de uma capacidade e a fase em que ela própria consegue se autodirigir nessa tarefa ${ }^{245}$. Os estágios III e IV correspondem, ambos, à fase posterior da aquisição/desenvolvimento de capacidade, quando o aprendiz consolida a nova competência, incluindo-a (como diria Bordenave) em seu repertório interior e predispondo-se para ascender novos degraus, reiniciando assim o ciclo .

O uso da palavra "competência" no parágrafo anterior, nada tem de fortuito, pois estamos tratando — de acordo com nossos autores - de capacidades cognitivas em um grau muito mais sofisticado que o dos conhecimentos "instrumentais". Assim, podemos definir competência como a "capacidade de mobilizar diversos recursos cognitivos para enfrentar um tipo de situações" (PERRENOUD, 2000: 15) ${ }^{246}$.

244 Embora, principalmente na fase inicial de sua carreira, Vigotsky tenha se dedicado à educação infantil, e mais tarde, à pesquisa dos distúrbios de aprendizagem, os discípulos e continuadores de sua obra transportaram seus conceitos, sem grandes tribulações, também para a educação de adultos.

245 Essa tarefa, que na definição da ZDP aparece como a "solução independente de problemas" (VIGOTSKY, 1998: 112), é tratada por Piaget como uma operação central da cognição. Tal ponto de vista permitiu dois grandes avanços pedagógicos: a ressignificação do verbo "problematizar" e a valorização do "erro", visto em Piaget não mais como algo a ser evitado ou punido, mas como um sintoma e um guia para facilitar o desenvolvimento infantil (PIAGET, 1977).

246 Podemos complementar expondo alguns dos aspectos relacionados às competências: "[1] As competências não são elas mesmas saberes, savoir-faire ou atitudes, mas mobilizam, integram e orquestram tais recursos. [2] Essa mobilização só é pertinente em situação, sendo cada situação singular, mesmo que se possa tratá-la em analogia com outras, já encontradas. [3] O exercício da competência passa por operações mentais complexas, subentendidas por esquemas de pensamento [Altet, 1996; Perrenoud, 19961, 1998g], que permitem determinar [mais ou menos consciente e rapidamente] e realizar [de modo mais ou menos eficaz] uma ação relativamente adaptada à situação" (PERRENOUD, 2000: 15). 
Buscando uma síntese desta conceituação, propomos um exemplo: aprender a dirigir. Trata-se de uma competência relativamente nova em termos de civilização humana, e que adquire um sem número de modalidades e variações, da equitação à pilotagem de naves espaciais. Por isso, vamos nos ater, no exemplo, ao ato de dirigir um automóvel.

Como essa tarefa é entendida no modelo de Vigotsky?

Em primeiro lugar, sabemos que o aprendiz não pode ser tomado como tabula rasa, já que possui seu próprio repertório de conhecimentos e habilidades (talvez até de traumas), que influenciarão o modo como transcorrerá o processo. Evidentemente, seu primeiro contato com um automóvel, na situação de condutor, será proporcionado (idealmente) em condições controladas e com a mediação de um agente (o mediador ativo, mencionado em nosso protomodelo) apto para tanto - geralmente um instrutor de volante - , no sentido de que ele sabe dirigir ${ }^{247}$ (competência técnica) e que sabe como ensinar a dirigir (competência pedagógica ou, pelo menos, didática).

Até aqui, cabe considerar também que o aprendiz optou por desenvolver essa habilidade e que, independente de fatores externos como pressão social e necessidade prática, ele quer aprender. Consideramos, então, que ele está predisposto para a mediação do instrutor de volante, na qual ele terá um papel bastante ativo (trata-se de uma interação intencional ou volitiva).

Num segundo momento, após um número variável de aulas práticas, nas quais o instrutor incessantemente corrigiu procedimentos, esclareceu dúvidas e demonstrou a prática correta $^{248}$ do que pode ser considerado como um ato cultural - ou seja, o ato de dirigir $^{249}$-, o estudante passa, ele próprio, a corrigir-se e a censurar-se pelas eventuais falhas de procedimento (esquecer de usar o cinto de segurança, ajustar os espelhos, etc.) mesmo sem a interferência do instrutor. Podemos dizer que ele está dentro da ZDP que vai da ignorância parcial do ato de dirigir até seu domínio minimamente admissível.

247 Levando em conta que o ato de dirigir é muito mais complexo que um simples exercício de adestramento da coordenação motora e uso da inteligência sensório-espacial. Para dizer o mínimo, observamos que ele envolve uma grande bagagem de conhecimentos técnicos, éticos e até o domínio de um sistema simbólico - o código de trânsito.

$248 \quad$ Vemos aqui um exemplo do esforço de mediação.

249 É preciso levar em conta que dirigir um automóvel é uma ação que só adquire um sentido racional dentro de um conjunto de normas e valores sociais que correspondem aos da sociedade ocidental, capitalista, produtiva ou qualquer outra muito parecida com ela. Esse sistema cultural específico justifica o ato da condução e seu aprendizado. 
O terceiro momento é marcado pelo salto quântico na capacidade do estudante, quando ele, mesmo sem haver atingido o grau de proficiência na "arte de dirigir", responde minimamente às exigências legais e sociais para fazer jus à carta de habilitação - licença com fé pública que reconhece nele um motorista (feedback social) ${ }^{250}$.

Em outras palavras: ele cruzou o limite da ZDP e apropriou-se, incluindo todo um conjunto de ações e conceitos ao seu repertório interior, do ato de interação social que corresponde à condução de automóvel ${ }^{251}$.

Podemos entender esta etapa como a sucessão de três sub-estágios: (1) interiorização - e seus desdobramentos —, (2) automatização e (3) fossilização.

É bem provável que o instrutor que mediou o processo - atuando entre o aprendiz/mediado e o sistema cultural no qual se insere o conhecimento de dirigir - fique satisfeito, pois sua mediação concretizou-se, isto é, seu objetivo foi plenamente cumprido.

Segundo Vigotsky, esse seria o momento do aprendiz reiniciar o ciclo do aprendizado, talvez aprendendo novas formas de dirigir (condução profissional, direção defensiva) ou partindo para outros domínios intelectuais e/ou práticos.

Aqui convém assinalar que Vigotsky deixou bem claro, em seu trabalho, a diferença entre a mediação de instrumentos e a mediação de signos ou semiótica, considerando a segunda como um desenvolvimento evolutivo da primeira. Segundo BLANCK (1996):

\begin{abstract}
“A palavra 'instrumentos’ faz alusão à mediação de processos mentais superiores. Os seres humanos modificam ativamente o estímulo que encontram, utilizando-o como instrumento de controle das condições circundantes, regulador de seu próprio comportamento. As investigações de Vygotsky tentaram descobrir como as pessoas, com a ajuda de instrumentos e símbolos, direcionam sua atenção, organizam a memorização consciente e regulam sua conduta. A essência do comportamento humano reside na mediação por instrumentos e símbolos. Os instrumentos orientam-se para fora, em direção à transformação da realidade física e social. Os símbolos são orientados para dentro, em direção à auto-regulação da própria conduta (...)" (BLANCK, 1996: 44).
\end{abstract}

250 "É nesse momento que o auxílio insistente de outras pessoas torna-se intrusivo e irritante. Até mesmo a autoconsciência é limitadora da integração harmônica de todos os componentes da tarefa. Este estágio se encontra além do autocontrole e do controle social. $\mathrm{O}$ desempenho não mais se encontra em desenvolvimento; de fato, já se desenvolveu plenamente. Vygotsky o descreveu como os 'frutos' do desenvolvimento; mas ele também o descreveu como 'fossilizado, enfatizando sua rigidez e seu distanciamento do dinamismo da mudança social e mental” (GALLIMORE \& THARP, 1996: 192).

251 "Esta concepção implica que a cultura não é simplesmente uma entidade independente dos indivíduos, com a qual eles devem negociar [Freud, 1927-1931]. Seres humanos são cultura interiorizada. A cultura, a acumulação da legitimação histórica da humanidade fora das fronteiras do organismo, é interiorizada como atividade mental, tornando-se, portanto, interna ao organismo" (BLANCK: 1996, 45 grifo nosso). 
Então, no modelo vigostkiano, entendemos que se trabalha com dois níveis de operações mentais, ambos formas de mediação da realidade pelo pensamento e ambos adquiridos pela experiência social (a qual, por sua vez, é mormente mediada por terceiros).

Destacando mais o papel do signo nessa relação mediatória, Vigotsky esclarece-nos que "a analogia básica entre signo e instrumento repousa na função mediadora que os caracteriza. Portanto, eles podem, a partir da perspectiva psicológica, ser incluídos na mesma categoria” e, para expressar essa relação lógica, recorre ao diagrama abaixo:

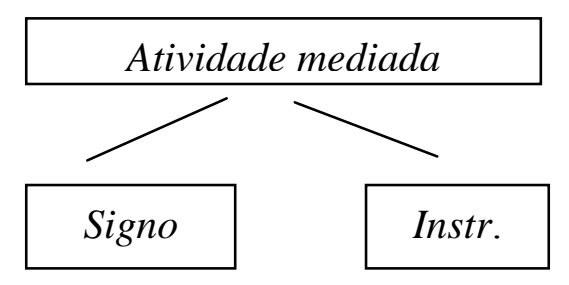

gráfico 12: relação lógica na mediação de signos e instrumentos (VIGOTSKY, 1998: 71)

Acreditamos ter realizado, até aqui, uma apresentação consistente do modelo de mediação em Vigotsky, relacionando seus elementos com os de outros modelos compatíveis. Nesta última designação, incluímos um modelo bem mais recente que incorpora o conceito de Midiatização.

\subsubsection{O modelo de análise das situações midiatizadas de ALAVA $^{252}$}

Antes de examinarmos este modelo, cuja importância reside em sua atualidade e na incorporação da questão midiática na MTE, é preciso, mais uma vez, resolver um embaraço léxico:o verbo mediatizar também grafado midiatizar (HOUAISS, 2007).

Dentro de nossa proposta de reduzir ao máximo o grau de incerteza no uso da mediação e expressões correlatas, cabe assinalar que o termo e seu objeto (mediação? mediatização? midiatização?) em questão aparecem sob três ${ }^{253}$ distintas acepções:

252 Séraphin Alava, Diretor do Instituto de Formação em Serviço de Professores da Universidade de Toulouse-Le Mirail, autor-organizador da obra Ciberespaço e Formações Abertas: rumo a novas práticas educacionais? (2002).

253 É preciso assinalar a importante contribuição de PERAYA (2002) no que toca a esse ponto específico: “(...) toda forma de comunicação tem como base um sistema de representação: não há comunicação que não seja mediatizada. Nossa experiência cotidiana da linguagem verbal, porém, nos leva a 
(a) no sentido estritamente político, como transposição não-literal do francês médiatiser, derivando aqui da interpretação de médiat (mediado) como dependent (dependente). “A expressão refere-se ao caso da anexação política de um estado nacional por outro sem perda da autoridade própria do estado anexado". É neste sentido estrito que o verbo aparece, por exemplo, no dicionário inglês (HOUGHTON MIFFLIN COMPANY, 2000-03). O léxico português-brasileiro DE HOLLANDA (2003) registra, com certa vagueza, o uso transitivo direto e indireto como "(2) mediar relações";

(b) no sentido sinonímico do verbo mediar amparado pelo léxico da língua portuguesa-brasileira que o assinala, ocorrente também em DE HOLLANDA (2003), como transitivo direto “(1) tornar mediato”. Essa parece ser a acepção manifesta por FREIRE em sua mais célebre frase: "Ninguém educa ninguém, ninguém educa a si mesmo, os homens se educam entre si, mediatizados pelo mundo" (FREIRE: 1987, 68 - grifo nosso). Ao que tudo indica, o educador pernambucano foi bastante imitado nesse uso um tanto impróprio (se considerarmos a etimologia original) da expressão;

(c) no sentido referente ao contexto midiático, escrito na maioria das vezes como "midiatização", que surge provavelmente como uma construção alternativa a "midiação". Essa forma derivaria de media, aportuguesada — pela sonoridade - como "mídia", e não teria relação direta com o inglês mediatize/mediatization. Quem apóia essa versão é o léxico português-brasileiro HOUAISS (2007) que anota como transitivo direto "difundir por meio dos veículos de comunicação".

crer na existência de uma comunicação não-mediatizada e, em nossa consciência ingênua dos fenômenos lingüísticos, a linguagem dita natural parece ser a expressão transparente, imediata de nosso pensamento. Mas, evidentemente, não é." (PERAYA, 2002: 26). Isto significa que, a despeito de nosso esforços, esta acepção difusa que mescla mediar/mediatizar ainda está arraigada e, provavelmente, em franco processo de acomodação semântica. Talvez a tendência vencedora, ao final, seja a de equiparar os dois termos e assumilos como sinônimos. 
PERAYA (2002) confirma em parte nosso raciocínio, assinalando que:

"A idéia de midiatização sugere também uma referência implícita a dois outros conceitos, que permitem delimitar e compreender as diferentes interpretações. Trata-se:

- do medium, essa intermediação obrigatória que torna mediata a comunicação entre professores e aprendizes: trata-se sempre de documentos impressos ou eletrônicos, de imagens e de textos, de planos visuais considerados erroneamente, na maioria das vezes como simples ilustrações, etc., portanto, como representações materiais (...);

- das mídias, no sentido de meios de comunicação de massa. Essa interpretação, quase espontânea, pode ser compreendida, porque, historicamente, o uso educativo das mídias - em particular o rádio e a televisão - e a criação de um gênero e de um estilo educativodidático — é que deram origem ao conceito de comunicação educativa midiatizada" (PERAYA, 2002: 26-27).

Tivemos que desfazer com alguma brevidade essa confusão potencialmente daninha ao nosso projeto, pelo simples fato de que o autor do modelo ora analisado - Séraphin Alava - utiliza, lado-a-lado, mediação e midiatização em seu construto.

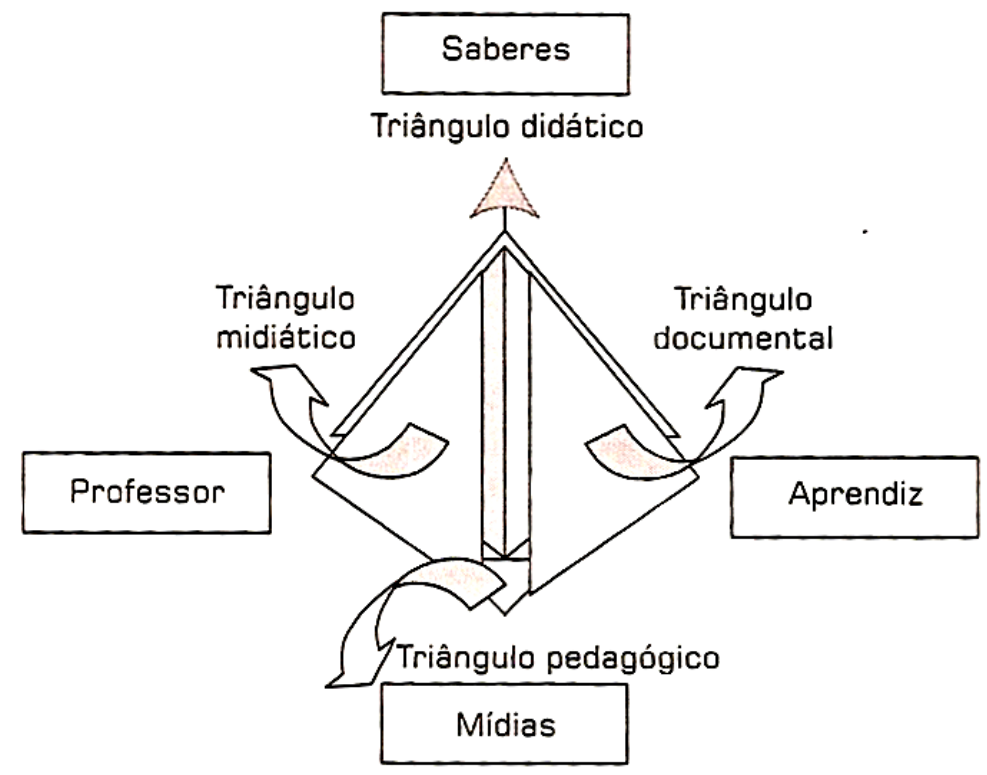

gráfico 13: Dinâmica didática e dispositivo midiatizado (ALAVA, 2002: 57) 
O referido modelo é um desenvolvimento do triângulo didático ${ }^{254}$ (ver gráfico 13) cujos pólos são constituídos pelos (1) Saberes (no alto), pelo (2) Professor e pelo (3) Aprendiz (no mesmo plano, abaixo dos saberes). Na parte inferior do triângulo, o autor acrescenta o elemento "Mídias", tentando descobrir seu lugar em um sistema do qual, a priori, prescindia ${ }^{255}$. Dessa forma, na primeira versão do modelo, as interações entre os elementos mediadores Professor/Aprendiz e destes dois com os Saberes (elemento mediado) não consideram a participação efetiva das mídias, dando-se à revelia destas.

Poderíamos dizer, em nossos próprios termos, que o esforço de mediação (apresentado de forma bastante discreta) origina o fluxo mediatório que vai do Aprendiz aos Saberes (formando o "Triângulo documental") e do Professor aos Saberes (formando o "Triângulo midiático") — isso tudo, à revelia do elemento "Mídias", o qual, no vértice de um "Triângulo Pedagógico", caminha em sentido contrário ao do processo de mediação envolvido $^{256}$.

Nesta construção, ALAVA coloca a questão das Mídias à margem do processo educativo, mesmo quando presentes, fato verificável em grande parte dos contextos educativos: "De fato, o modelo didático rejeita o dispositivo e o contexto externo à preocupação do pesquisador. A relação entre essas três instâncias parece então, direta e não-midiatizada" (ALAVA, 2002: 57).

A razão principal desse descompasso seria a oposição histórica entre o saber que se traduz na escrita — o qual é o suporte básico dos Saberes na escola - e as (relativamente) recém-chegadas mídias, que rompem com a lógica da textualidade linear exigindo novos modos de transposição didática.

Assim, no modelo reconstruído (ver gráfico 14), ALAVA demonstra como a inclusão da midiatização - efetuada em conjunto e em paralelo com a mediação (agora bastante evidenciada) — estabelece uma estrutura totalmente diferenciada da anterior, na qual o fluxo mediatório difunde-se bidirecionalmente (setas em cor cinza) entre todos os elementos envolvido no processo educativo.

\footnotetext{
254 Ao que tudo indica (embora o autor não o mencione), emprestado do artigo Recherches en didactiques des mathématiques de G. Brousseau (1986).

255 Pergunta levantada pelo autor: “(...) Jean Piaget não descreve o audiovisual como um simples auxiliar técnico na aula?” (ALAVA, 2002: 54).

256 Denotando, também, uma cisão nítida entre os enfoques Didático e Pedagógico.
} 
Segundo o autor:

O modelo midiático deve ser, então, reformatado para que a mídia tenha lugar na triangulação anterior. $\mathrm{O}$ dispositivo midiatizado interage na seleção, no tratamento e na transmissão do saber teórico. 'Sem transmissão, em tradução e traição', lembrava B. Latour para evidenciar o efeito das mídias na difusão dos saberes científicos. A midiologia de Régis Debray propõe-se, por outro lado, a esclarecer esse efeito de 'transmissão' cultural, técnica e social. As ciências da comunicação, ao aprofundar essa inter-relação dialética entre a mensagem e o meio, confirmam a impossibilidade para o pesquisador em ciências da educação de excluir o dispositivo dessas preocupações" (ALAVA, 2002: 60).

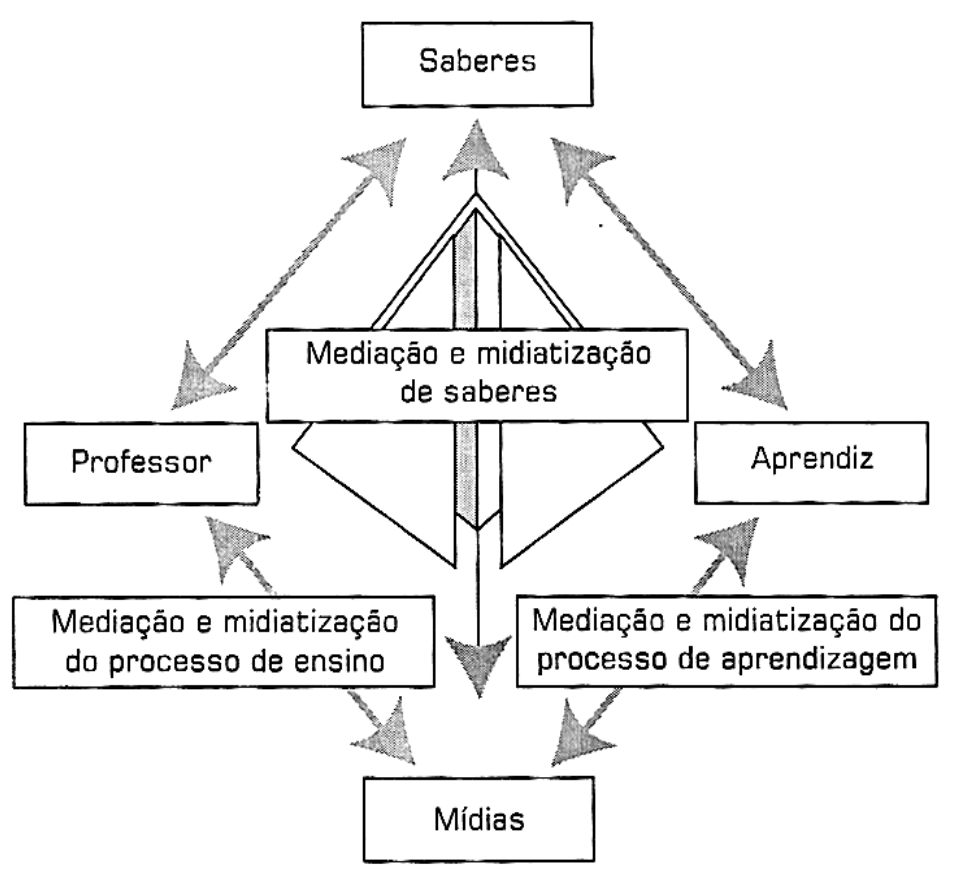

gráfico 14: Mediação e midiatização dos processos de formação (ALAVA, 2002: 60)

Parece-nos que o conjunto de modelos aportados da Comunicação e da Educação e apresentados de forma comparativa nesta seção é suficiente para realizar duas tarefas a que nos propomos para encerrar o presente capítulo:

(1) realizar uma síntese interpretativa dos modelos visuais e

(2) reconstruir nosso modelo elementar, de modo que ele incorpore contribuições dos diferentes modelos analisados e resulte no modelo de mediação educomunicativa que buscamos. 


\subsubsection{Interpretação sobre os modelos gráficos}

Na presente seção, propomo-nos a esboçar um modelo que facilite a compreensão das implicações epistemológicas da mediação, levando em conta que a incipiência de nosso protomodelo não abarcava a dimensão e a complexidade inerentes ao exercício da mediação educomunicativa. Assim, alguns elementos deverão ser acrescentados às formulações originais - como os conceitos de mediância e mediatividade aqui propostos - e outros melhor desenvolvidos — como a questão do objeto na mediação. O que buscamos, com tais acréscimos, é uma contribuição efetiva para o entendimento e contextualização da MTE na Educomunicação.

Esse modelo complexo a que nos referimos será desenvolvido a partir da assimilação de elementos dos modelos comunicativos e educacionais que analisamos até aqui, na esperança de compor e fortalecer os conceitos-parâmetros que utilizaremos para avaliar projetos de MTE.

Para não nos apartarmos das aquisições teóricas e conceituais expressas no final do capítulo anterior e na primeira parte do presente, listaremos alguns pressupostos de base sobre a mediação. Em seu conjunto, eles são constatações - mas também inferências que pudemos abstrair da análise etimológica e da aproximação de idéias entre os autores do campo da Comunicação e os educadores da corrente sociointeracionista e, principalmente, da obra de Vigotsky:

\section{I. a mediação educomunicativa é um fenômeno de natureza estritamente} cultural ou, se preferirmos, sociocultural (Serrano, Martín-Barbero). Essa concepção de cultura integrada (ou imbricada) no plano social origina-se, em grande parte, dos estudos marxistas. Ao que tudo indica, a conceituação de cultura em Vigotsky ${ }^{257}$ revela-se bem próxima daquela estabelecida pelos

257 COLE assinala que “(...) a idéia básica que pode ser retrospectivamente traçada até a antigüidade e que forma a base de boa parte da teorização antropológica, é a noção de que os seres humanos vivem em um ambiente transformado pelos artefatos das gerações anteriores, estendendo-se até o início das espécies. A função básica desses artefatos é coordenar os seres humanos com o mundo físico e uns com os outros. Em conseqüência, os seres humanos habitam um 'mundo duplo', ao mesmo tempo 'natural' e 'artificial'. A cultura nesse sentido deve ser considerada o único meio da existência humana" (COLE, 1996: 87). 
$\operatorname{comunicólogos}^{258}$ pois, numa mesma tentativa de "abandonar o positivismo sem cair no reducionismo funcionalista, ele apresenta sua psicologia como sóciohistórico-cultural” (BLANCK, 1996: 42);

II. a mediação - como assinalado anteriormente, ao apresentarmos nosso protomodelo - é um processo dinâmico (não um “estado"), isto é, implica na interação ativa dos elementos que nela se relacionam. Nesse sentido, reforçamos que mediador é todo aquele que participa do processo mediatório, variando o grau de protagonismo que cada um exerce na condução do processo $^{259}$;

III. essa participação ativa, por sua vez, implica e apóia-se na existência de quatro pré-condições inter-relacionadas, as quais podem se manifestar com maior ou menor intensidade ${ }^{260}$, clareza $^{261}$ e completude ${ }^{262}$. São elas:

a. intencionalidade, isto é, a presença de um propósito ou deliberação definido a priori, sem a qual o processo mediatório perde seu sentido;

b. consciência, colocada no sentido de "percepção" mais ou menos precisa das causas e conseqüências do processo;

c. consensualidade, identificada com a concordância (anuência) em relação ao propósito e às condições envolvidas no processo;

d. simetria, entendida como a relativa igualdade ou equivalência de "poder" para dirigir ou influenciar o processo da mediação;

258 Provavelmente por influência comum do pensamento histórico-dialético.marxista.

259 Para aclarar melhor esse aspecto propomos, ainda neste capítulo, as noções de Mediatividade e Mediância.

260 "Característica do que é intenso; força, vigor" (HOUAISS, 2007).

261 "Qualidade do que é inteligível" [desambigüidade] (HOUAISS, 2007).

262 "Qualidade, estado ou propriedade do que é completo, perfeito, acabado" (HOUAISS, 2007). 
IV. além de dinâmico, o processo da mediação é cíclico, isto é, ele não apenas "comporta", mas alimenta-se do feedback como um apoio ao esforço de mediação. Essa realimentação manifesta-se de forma comunicativa, reorientando o trabalho do mediador de acordo com a necessidade do contexto;

V. podemos considerar a existência de um quadro mínimo de elementos constituintes (ou estruturais) do processo mediatório, a saber:

a. os agentes mediadores, que são sempre, em maior ou menor grau, protagonistas da mediação - isto é, demonstram poder de condução _-, o que acarreta a inexistência de sujeitos totalmente mediados, ou seja, sem voz ativa no processo. O protomodelo pode ter dado uma impressão simplista do processo de mediação, fazendo entender que A e C equivaleriam a "indivíduos" entre os quais B faria a mediação. Entenda-se, no entanto, que o esforço de mediação que é dispendido por B (ATENÇÃO: a letra representa uma posição relativa na estrutura da mediação, não um ente individual específico) vai ao sentido de aumentar o coeficiente comunicativo ${ }^{263}$ entre um objeto de mediação - C, por exemplo - e o outro pólo da mediação, representado por $\mathbf{A}^{264}$;

\footnotetext{
263 Esse conceito, já referido em nota de rodapé no capítulo I, é, segundo TAVARES JR.: "O conceito de 'coeficiente comunicativo' diz respeito à intensidade quantitativa e qualitativa das diferentes formas de expressão e comunicação tanto entre indivíduos como entre um centro emissor e uma grande audiência. Tratase de responder à seguinte pergunta: De que forma e quanto os indivíduos e os grupos estão se comunicando? Leva em conta não apenas a quantidade de emissão de mensagens, mas também a complexidade tanto da própria mensagem como do processo criado na relação emissor-receptor. Trata-se de transformar relações burocráticas, pragmáticas e frias em 'trocas' ricas, profundas, educativas e envolventes" (TAVARES JR., 2007: 73). Esta síntese do autor tem por base as colocações de Martín-Barbero e Ismar de O. Soares.

264 Talvez haja a necessidade de se estabelecer - o que evitamos claramente até aqui — uma distinção nominal de papéis entre o mediador ativo, que concentra o protagonismo, e o outro mediador, parceiro ou coadjuvante. Dada a relação de poder implícita, em maior ou menor grau, nesses conceitos, preferimos deixar esta lacuna por preencher.
} 
b. o objeto da mediação, que acrescentamos a nosso modelo com base no conceito de objeto cultural ${ }^{265}$. Nesse sentido, a escola geralmente entende que o objeto de mediação seja o conjunto dos saberes constituídos, enquanto os meios consideram que ele seja a informação. Em algum ponto do caminho entre uma visão e outra, a Educomunicação define (caso a caso) ou definirá (epistemologicamente, como conceito) seu próprio objeto;

c. os objetivos da mediação, já que o processo mediatório não se encerra nele próprio, têm que ser orientados para conduzir da necessidade aos resultados. Não podemos negar a dificuldade que existe em se manter, numa perspectiva que valoriza o protagonismo do sujeito, a noção usual de objetivo como item formal de um projeto de ação (ainda que educomunicativa). Por ora, apontamos como apoio a noção expressa por BOUTINET, para quem "Os objetivos não são mais que o centro do dispositivo, mas apenas um de seus elementos, elemento regulador da ação a ser empreendida, elemento certamente importante, porém com a condição de ser recolocado no contexto que lhe dá pertinência” (BOUTINET, 2002: 192);

d. os fluxos mediatórios, linhas imaginárias que indicam o sentido, a intensidade e a direcionalidade da mediação. Ainda que representem uma ação imaginária, entendemos que podem ser uma abstração útil para avaliar parâmetros, como o coeficiente comunicativo e o protagonismo envolvidos na mediação educomunicativa;

265 De acordo com DUARTE: "Um objeto cultural, seja ele um objeto material, como por exemplo um utensílio doméstico, seja ele um objeto não material, como uma palavra, tem uma função social, tem um significado socialmente estabelecido, ou seja, deve ser empregado de uma determinada maneira (o fato de que o objeto cultural tenha, muitas vezes, mais de uma função não altera a regra de que sua existência está necessariamente ligada à prática social. $\mathrm{O}$ processo de objetivação é, portanto, o processo de produção e reprodução da cultura humana (cultura material e não-material)" (DUARTE, 2005: 33). De acordo com o mesmo autor, "objetivação" é um conceito marxista aportado por Leontiev ao sociointeracionismo. 
e. o espaço da mediação, o meio por excelência, não só como um lugar imaginário do tipo "neutro", mas o ambiente em toda a sua especificidade, permeável ao fluxo constante de interações. A Educomunicação adotou, em seus pressupostos, o conceito de "ecossistema comunicativo-educativo", o qual pode ser entendido como um espaço de mediação reconhecível e estruturado;

f. os resultados da mediação, que são referenciados nos objetivos e expectativas (motivações, necessidades) pré-estabelecidos pelos mediadores na forma de concretização de seus objetivos previamente acordados. Como assinalado anteriormente, a ação busca a sinergia.

Os tópicos descritos acima representam o primeiro esboço de um modelo em construção e não de um esquema pronto e acabado. Consideramos, porém, que servem já como base para a edificação de uma modelo objetivo mais próximo - ainda que por analogia - das aplicações que a Educomunicação encontra nos contextos que a acolhem

Uma vez que evitamos a tarefa de mapear um quadro político dentro da relação mediatória, assumimos, em troca, a proposta de definir novos parâmetros para conceituar a matriz do protagonismo exercido pelos mediadores. Assim, julgamos oportuno apresentar os termos que desenvolvemos com base na idéia de modalidades de ação mediadora, aos quais preferimos chamar de (1) Mediância e (2) Mediatividade.

Vamos ao seu detalhamento:

Levando em conta que a mediação é uma ação executada por agentes bem definidos, seu exercício pode ser observado e qualificado à luz do maior ou menor grau de iniciativa das partes envolvidas ${ }^{266}$. Essa prerrogativa - que na prática, no mais das vezes, é já fornecida por instituições organizadoras ${ }^{267}$ — define o papel e os limites da atuação mediadora.

266 O qual, por sua vez, denota geralmente uma co-relação com o grau de consciência maior ou menor do mediador a respeito do processo (objetivos, objeto, espaço, etc.).

267 O que não impede, eventualmente, que seja subvertida - não necessariamente por um viés depreciativo - pelos envolvidos no processo. 
Posto isso, denominamos mediatividade à capacidade do agente para influenciar e conduzir o processo da mediação, enquanto chamamos mediância à atitude coadjuvante ou de "menor proatividade 268 " do mediador.

A escolha por mediatividade não se baseia em grandes rebuscamentos lingüísticos: apenas pretende asseverar o caráter de atividade já inferido no sufixo ação da própria palavra mediação.

Já a construção mediância é uma derivação simples (adjetivação e nova substantivação) do substantivo mediante ${ }^{269}$. Há uma indicação na etimologia do italiano (idioma em que o termo "mediante" ocorre com a mesma grafia e sentido que no português) sobre a existência do termo mediãns como origem de mediantis (BATTISTI \& ALESSIO, 1952: 2402).

É importante esclarecer que esses conceitos não constituem um par de opostos perfeito, isto é, não podem ser considerados antônimos, caso contrário, só precisaríamos de um dos conceitos, pois a ausência (ou negatividade) da qualidade a ele associada poderia ser expressa em termos de grau - maior ou menor. Essa não é nossa intenção, por isso, frisamos que a mediatividade equivaleria, na Comunicação, à ação do emissor e a mediância à do receptor. Já no campo da Educação, a analogia fica por conta da relação Professor/Educador (mediativo) e Aluno/Aprendiz (mediante).

Assim, acreditamos que fica evidenciado o grau de complexidade das relações envolvidas, que não caberiam em parâmetros simples como "mais ativo", "menos ativo", "com poder de decisão" ou "sem poder de decisão" e similares, uma vez que os protagonistas em situações reais apresentam um leque de possibilidades muito maior do que os papéis a eles destinados pela convenção do senso comum.

Por outro lado, é quase desnecessário assinalar que nenhum dos dois termos consta no léxico português-brasileiro.

\footnotetext{
268 O adjetivo "Proativo" figura no léxico como "que visa antecipar futuros problemas, necessidades ou mudanças; antecipatório" (HOUAISS, 2007). No jargão coloquial da metodologia de projetos e, por contaminação extensiva, proatividade é entendida, muitas vezes, como "iniciativa” em um grau elevado.

269 Registrado no léxico como adjetivo e proposição sem perder o sentido de "função de intermediário" (HOUAISS, 2007). A título de curiosidade, no jargão da Música — nossa influência assumida —, o termo (no feminino: "a mediante") denomina a nota que numa escala musical define se o modo é menor ou maior.
} 
Em relação a tudo o que colocamos até aqui e para transcendermos o nível do raciocínio espacial básico - exatamente aquele empregado na composição do protomodelo -, recorreremos a outro modelo analógico, ao qual chamaremos de "Metáfora da Orquestra”.

\subsubsection{A Metáfora da Orquestra}

Em nosso trabalho, consideramos pertinente oferecer alguma contribuição que ajude a melhorar o entendimento de nosso objeto de estudo e facultar, aos interessados, indícios metodológicos (mas não "um método") de alguma aplicabilidade prática, ao menos, no campo organizacional.

Nesse sentido, a maneira mais simples e direta que nos ocorreu, foi a apresentação de um modelo construído a partir de um raciocínio analógico, ao qual chamamos de Metáfora da Orquestra.

Primeiro, para sistematizar os apontamentos reunidos no subitem anterior, faremos uso de um novo quadro referencial (quadro 23). 


\begin{tabular}{|c|c|}
\hline \multicolumn{2}{|c|}{$\begin{array}{c}\text { QUADRO ESQUEMÁTICO: MODELO PARA A MEDIAÇÃO } \\
\text { EDUCOMUNICATIVA }\end{array}$} \\
\hline Elementos da mediação & Perguntas contextualizadoras \\
\hline agentes mediadores: & $\begin{array}{l}\text { - quais são os agentes da mediação? } \\
\text { - quem são os agentes e "de onde" (a partir de que } \\
\text { universo cultural) eles falam? } \\
\text { - quem concentra o protagonismo no processo? }\end{array}$ \\
\hline objeto da mediação: & $\begin{array}{l}\text { - pode-se definir, com clareza, o objeto da mediação? } \\
\text { - em qual universo cultural estamos trabalhando (de } \\
\text { qual conceito de "Cultura" se fala)? } \\
\text { - sob quais diferentes enfoques se pode apreender esse } \\
\text { objeto? }\end{array}$ \\
\hline objetivos da mediação: & $\begin{array}{l}\text { - o que se busca, ao final? } \\
\text { - que processos possibilitaram a escolha desse(s) } \\
\text { objetivo(s)? } \\
\text { - os objetivos foram instrumentalizados (ou seja, } \\
\text { formulados em termos técnicos tais como objetivos } \\
\text { gerais, específicos, metas e ações)? } \\
\text { - o processo de avaliação objetiva (objetivos } \\
\text { alcançados/não alcançados) foi previsto? }\end{array}$ \\
\hline fluxos mediatórios: & $\begin{array}{llr}\text { existe bidirecionalidade real } & \text { (nos } & \text { fluxos } \\
\text { tecnologicamente mediados, } & \text { falamos } & \text { em } \\
\text { interatividade)? } & & \\
\text { - existem gargalos e/ou bloqueios? } & & \\
\text { - existe o feedback? }\end{array}$ \\
\hline espaço da mediação: & $\begin{array}{l}\text { - a mediação ocorre em um espaço determinado? } \\
\text { - trata-se de espaço físico, virtual ou de ambos? } \\
\text { - trata-se de um espaço institucional? De que natureza? } \\
\text { - a estrutura do ecossistema educomunicativo é } \\
\text { transparente? }\end{array}$ \\
\hline resultados da mediação: & $\begin{array}{l}\text { - o processo foi concluído? } \\
\text { - o que foi alcançado? } \\
\text { - como se realiza a avaliação? } \\
\text { - como o processo foi registrado? } \\
\text { - qual será o passo seguinte? }\end{array}$ \\
\hline
\end{tabular}

quadro 23: síntese dos elementos da mediação/perguntas contextualizadoras

270 Isso implica, em alguma medida, em refazer o percurso do mencionado processo de objetivação cultural. 
Em segundo lugar, vamos à aplicação dos conceitos delineados numa situação hipotética: um concerto de orquestra ${ }^{271}$. A escolha pelo modelo tomado de empréstimo à Música justifica-se por quatro motivos:

(1) nele podem ser exemplificados todos os elementos e parâmetros propostos no presente capítulo com razoável grau de clareza;

(2) a orquestra, como um "mediador cultural" (que também pode ser considerado um "objeto cultural", dependendo do enfoque), é imagem de fácil assimilação na maioria dos contextos;

(3) o duplo caráter expressivo e formativo/informativo ${ }^{272}$ do evento social "concerto" apresenta pontos de contato que podem ser assimilados à Educação e à Comunicação, indistintamente;

(4) de modo mais sutil, a "organização orquestra" e o campo das Artes podem representar um contraponto e talvez um campo neutro em relação aos já tratados universos da Comunicação e da Educação.

Assim, prosseguindo em nosso raciocínio, podemos dizer que o concerto é uma mediação cultural realizada entre uma obra de arte musical, composta há séculos (objeto cultural), e o público que se dirige ao local da apresentação (mediador cultural, mais mediante que mediativo), com o objetivo de apreciá-la (objetivo cultural).

Nessa analogia, encontramos as seguintes correspondências "primárias":

a. o intérprete é quem controla o instrumento, ele é quem executa o ato de tocar. Logo, dizemos que ele apresenta grande mediatividade;

271 "Termo que designa uma apresentação musical pública, habitualmente implicando a interpretação por parte de uma orquestra. Até meados do século XIX, um concerto podia significar qualquer tipo de entretenimento não-teatral. Para uma apresentação em menor escala, costuma-se preferir o termo 'recital'." (GROVE, 1994: 212). Essa acepção corresponde ao sentido lato da palavra, já o sentido estrito refere-se a uma forma orquestral de três movimentos que se origina no Período Barroco.

272 Podemos registrar que esse duplo caráter não é incomum nas práticas educomunicativas. 
b. o objeto mediado é a música, aquele que existe em potencial na partitura, mas que, sem o ato da mediação (e o mediador), não tem como se manifestar;

c. o público em si, longe de ser um elemento figurativo na relação, é parte ativa do processo de mediação cultural: além dele ser a justificativa social a priori para a realização do concerto (se o público não fosse ao teatro, o evento nem aconteceria), suas reações, que podem variar do entusiasmo e arrebatamento embevecidos, passando pela indiferença, até as raias da hostilidade, são um feedback capaz de mudar totalmente o caráter e a qualidade da apresentação. Não obstante, dizemos que sua mediância supera sua mediatividade;

d. a instituição que produziu o concerto, ao contrário do que possa parecer, exerce um papel muito discreto, uma vez que não participa ativamente do tempo da mediação ${ }^{273}$;

e. quaisquer outros agentes indiretos - à exceção dos críticos que repercutirão o êxito ou o fracasso da apresentação - , tais como compositores vivos ou mortos que compuseram a música, mediadores ocasionais (monitores de visita), montadores, copistas e auxiliares, ficam de fora desta análise.

273 Inserimos aqui mais uma variante para análise futura, com certeza, além do escopo desta tese. 


\section{QUADRO ESQUEMÁTICO: MODELO PARA A MEDIAÇÃO EDUCOMUNICATIVA}

\section{Perguntas contextualizadoras}

Respostas no contexto

agentes mediadores

A- quais são os agentes da mediação?

B- quem são os agentes e "de onde" (a partir de que universo cultural) eles falam?

$\mathrm{C}$ - quem concentra o protagonismo no processo?

\section{objeto da mediação}

A- pode-se definir com clareza, o objeto da mediação?

B- em qual universo cultural estamos trabalhando? de qual conceito de "Cultura" se fala?

C- sob quais diferentes enfoques se pode apreender esse objeto?

\section{objetivos da mediação}

A- o que se busca, ao final?
(A1) os Intérpretes: o Regente e os Músicos, (A2) o público, (A3) a produção do evento;

(B) os apreciadores da Música Clássica, determinada pelo meio cultural "Erudito";

(C) os Intérpretes, por ocasião da performance (considerada como o momento da mediação)

(A) em sentido mais estrito seria (A1) a obra executada, mas podemos entender (A2) a arte musical e (A3) a cultura erudita, dependendo do enfoque da mediação.

(B) o universo cultural erudito ou clássico, se constitui a partir do uso consagrado (e elitista) da cultura, explicitado, por exemplo, em ADORNO (2007);

(C1) crítico cultural, (C2) estético (expressão artística), (C3) social (como evento social), (C4) fenomenológico, etc.

(A1) materializar uma vivência compartilhada em sentido e significação para um grupo seleto de ouvintes; (A2) lucro financeiro, sustento da orquestra; (A3) ganho institucional, reconhecimento dos intérpretes e, por extensão, da instituição.

B- que processos possibilitaram à escolha deste(s) objetivo(s)?

C- os objetivos foram instrumentalizados (ou seja, formulados em termos técnicos tais como objetivos gerais, específicos, metas e ações)?

D- o processo de avaliação objetiva (objetivos alcançados/não alcançados) foi previsto?
(B1) organização (produção), (B2) preparação (ensaio), (B3) divulgação (instituição), (B4) agendamento (público).

(C) com certeza: a instituição segue um modus operandi que se estende à rotina da orquestra em seu plano de gestão;

(D) não, a avaliação será expressa (D1) em tempo real pela aprovação/reprovação do público e (D2) posteriormente pela crítica especializada e, dependendo da repercussão, (D3) a avaliação institucional remodelará o quadro de intérpretes. 


fluxos mediatórios
A- existe bidirecionalidade real (nos
fluxos tecnologicamente mediados,
falamos em interatividade)?
B- existem gargalos e/ou bloqueios?

C- existe o feedback?

espaço da mediação

A- a mediação ocorre em um espaço determinado?

B- trata-se de espaço físico, virtual ou de ambos?

C- trata-se de um espaço institucional?

De que natureza?

D- a estrutura do ecossistema educomunicativo é transparente?

B- o que foi alcançado?

C- como se realiza a avaliação?

resultados da mediação

A- o processo foi concluído?
Existe uma bidirecionalidade limitada (A1) entre a produção ( $>$ mediatividade) e os intérpretes ( $>$ mediância) que se reproduz, parcialmente, na relação (A2) entre os intérpretes ( $>$ mediatividade) e o público ( $>$ mediância).

(B) podem ocorrer por conta de (B1) inadequações circunstanciais do ambiente (ventilação, barulho, falta de espaço ou de assentos), (B2) falta de sinergia ente os intérpretes ou de domínio sobre a obra executada ou ainda, (B3) por falta de referenciais por parte do público para fruir de objeto cultural dessa natureza.

(C) o feedback é esperado na reação do público.

(A1) sim, usualmente: trata-se do espaço da sala de concerto, ou algum outro adaptado para esse fim.

(B1) o espaço é físico para o público presente e (B2) virtual para os receptores radiofônicos e televisivos do concerto.

(C) também estamos no campo de uma instituição, que pode ser identificada de várias formas, de acordo com seu grau de mediatividade (o governo, a classe artística, um patrocinador, uma $\mathrm{ONG}$, etc.)

(D) de certa forma, sim para (D1) os intérpretes que têm contato com todos os pólos da mediação e um pouco menos para (D2) o público que não tem contato com (D3) a produção (e vice-versa).

Depende do âmbito pretendido: o final do concerto, do ponto de vista do mediador-intérprete, pode marcar (A1) o fim de um processo de curto âmbito (sessão), (A2) o início de um processo maior (temporada), (A3) parte de uma rotina (atuação). Para o público, que aqui desconhecemos, é ainda mais difícil definir o âmbito.

Na avaliação objetiva, (B1) a execução programada, com maior ou menor grau de felicidade, na subjetiva, (B2) variável;

Dentro do grupo de intérpretes, $(\mathrm{C} 1)$ o regente ocupa uma posição privilegiada para avaliar o resultado (a sinergia do concerto), do lado de fora, (C1) o público faz uma avaliação que pode ser homogênea ou heterogênea, e (C2) a crítica especializada, uma avaliação pontual. $\mathrm{O}$ conjunto dessas avaliações geralmente é avaliado pela (C4) produção, que deve levá-lo em conta nas próximas récitas. 
D- como o processo foi registrado?

E- qual será o passo seguinte?
(D) o resultado pode ser registrado (midiatizado) em suporte audiovisual $^{274}$.

(E) neste contexto, tudo depende dos objetivos dispostos anteriormente.

\section{quadro 24: aplicação da Metáfora da Orquestra}

Com base em nossos desenvolvimentos reflexivos até aqui, pudemos detectar algum avanço maior no tocante às categorizações possíveis dentro do conceito de mediação.

No próximo capítulo, ocupar-nos-emos dos aspectos históricos relacionados com a MTE, os quais incorrem tanto no mapeamento das expressões que lhe são correlatas quanto na discussão sobre a interface entre os outros dois elementos pertinentes a nossa equação $^{275}$ : a Tecnologia e a Educação.

274 No meio cultural específico à música erudita, o registro não é desejável, já que se considera a natureza única e irrepetível da experiência musical. Em tempos de prevalência do mercado, esta se transforma quase que numa questão estritamente contratual.

275 Visto que, até aqui, nos concentramos com mais ênfase nos referenciais oriundos da Comunicação. 


\section{CAPÍTULO IV}

\section{MTE: A HISTÓRIA DE UM CONCEITO}




\subsection{MTE: a história de um conceito}

\footnotetext{
"O que ocorre é que há etapas, nas culturas, em que as mudanças se dão de maneira acelerada. É o que se verifica hoje. As revoluções tecnológicas encurtam o tempo entre uma e outra mudança.”. (FREIRE, 2000: 30)
}

Ao iniciarmos este novo capítulo, acreditamos já ser viável esboçar uma concepção própria sobre o conceito de mediação, ou pelo menos, de como a mediação opera na interface entre Tecnologia e Educação dentro do âmbito da Educomunicação.

Assim, as afirmações e análises que seguem, ganham significância e exatidão, na medida em que se aplicam ao nosso objeto de estudo — isto é, não as estenderemos, neste momento - aos processos de mediação num sentido geral ou específico de outros processos que não os aqui analisados.

Antes de prosseguir, convém assinalar as conclusões provisórias que pudemos relacionar até agora:

(1) a mediação educomunicativa é um processo intencionalmente construído ao longo de uma relação educativa e comunicativa de contornos e intenções claras;

(2) ela só pode ser alvo de qualificação, dentro de um contexto conhecido. Dessa forma, pode-se justificar o uso de termos positivos (somativos) como "mais consistente, "mais focada", "mais abrangente" ou negativos (subtrativos), como "menos conflitiva", "menos dispersiva" - mas nunca juízos de valor binários do tipo "boa"; "ruim", "melhor", "pior", etc.

(3) é preciso levar em conta que a mediação sempre se realiza (ou não), da perspectiva do mediador, o qual, idealmente, deve ser uma das partes simétricas que interagem na relação mediadora. 
Agora que inserimos nosso objeto de estudo dentro de uma relação significado/significante, envolveremos em nossa discussão outros elementos de debate, mais ligados à interface entre Educação e Tecnologia.

O assunto principal desta seção é a MTE enquanto conceito, tal como ele se evidencia, mantendo elementos e características que a identificam como uma forma específica de mediar, em diversos contextos históricos e geográficos.

A título de recordação, lembramos que SOARES define a MTE como o

\footnotetext{
"Estudo das mudanças decorrentes da incidência de inovações tecnológicas no cotidiano das pessoas e grupos sociais, assim como o uso das ferramentas da informação nos processos educativos, sejam presenciais, sejam a distância (SOARES, 2002a: 18).
}

O foco deste enunciado não se perdeu no tempo afinal, muito do que se afirmou com relação à Tecnologia no início do milênio já hoje caiu por terra - mas merece alguns adendos.

Em primeiro lugar, falar da MTE, como de qualquer uma das áreas de intervenção (mencionadas em no capítulo I) como uma vertente de estudos, é dizer pouco, uma vez que a vocação empreendedora do NCE-ECA/USP ${ }^{276}$ resultou em numerosas modalidades de intervenção que tiveram lugar nos projetos educomunicativos.

De todos os projetos que poderíamos tratar no âmbito de nossa análise, aquele que mais relevância demonstra quando o foco é a MTE, é sem dúvida o curso Formação Continuada de Professores em Mídias na Educação. Antes de analisá-lo em sua especificidade, trataremos de estabelecer a ligação entre as reflexões de cunho filosófico e teórico constantes dos capítulos II e III e o conceito reconstruído de MTE.

Reafirmamos nossa premissa de que, as diversas abordagens teóricas e práticas envolvendo a tríade Comunicação-Tecnologia-Educação - as quais ocorrem nos ecossistemas educativos formais e não-formais - caracterizam-se como modalidades de MTE, de acordo com os parâmetros que estabelecemos no capítulo anterior.

Constatamos também, a dificuldade de encontrarmos uma denominação unívoca que defina, sem dubiedade, o papel da tecnologia nos processos educomunicativos, o que

276 Cuja síntese das principais ações também é relatada no primeiro capítulo desta tese. 
nos leva — antes de tudo — a aprofundar com um pouco mais de rigor, o conceito de Tecnologia sobre o qual estamos trabalhando.

\subsubsection{Um conceito para a Tecnologia}

O comunicólogo canadense H. Marshall McLuhan foi feliz ao definir os meios de comunicação como extensões do homem (1996). De fato, a comunicação, ou melhor, seu domínio conceitual e "técnico" foi o que permitiu ao homem incrementar a própria evolução (no sentido darwiniano mais estrito) e, não seria errado dizer que, tanto ou mais que os chamados "insetos sociais", somos dependentes da organização da vida em sociedade, sem a qual, não existiria nada parecido com o que chamamos "civilização"277.

Do ponto de vista do senso comum, é fácil lembrar das ferramentas desenvolvidas pela tecnologia como sendo as próprias extensões, desde as mais rudimentares - como as pedras e varas ${ }^{278}$ — até as mais sofisticadas máquinas e sistemas digitais.

Colocado dessa forma, a imagem nos induz a pensar que a ciência da comunicação seja, ela própria, um processo tecnológico, raciocínio que ganha reforço quando o campo da comunicação ganha o status de "ciência social aplicada". Um diferencial inolvidável é que estamos falando aqui, não de tékhné frg $^{2}$ mas da compreensão causal (e, portanto, projetiva) dos efeitos de tal aplicação. Dito de outra forma: ainda que os processos comunicativos sejam abordados com vistas ao seu papel transformador social, sua especificidade ressalta a dimensão cultural dessa transformação.

277 Em célebre passagem de sua obra mais conhecida, MARX - e não nos esqueçamos do papel do marxismo "herdeiro filosófico" da filosofia de Hegel - se apóia neste exemplo específico para falar do significado do trabalho enquanto atividade, primordialmente intelectual: "pressupomos o trabalho numa forma em que pertence exclusivamente ao homem. Uma aranha executa operações semelhantes às do tecelão, e a abelha envergonha mais de um arquiteto humano com a construção dos favos de suas colméias. Mas o que distingue, de antemão, o pior arquiteto da melhor abelha é que ele construiu o favo em sua cabeça, antes de construí-lo em cera. No fim do processo de trabalho obtém-se um resultado que já no início deste existiu na imaginação do trabalhador, e portanto idealmente" (MARX, 1996: 298). Anos mais tarde, Vigotsky se lembraria de citar esta mesma passagem na conferência que o trouxe em Moscou, em 1925, segundo relata seu discípulo A.R. Luria (LURIA, 2001: 25).

278 Cujo uso é compartilhado com várias espécies animais, taxonomicamente próximos, como os chimpanzés, ou distantes como as lontras marinhas e os corvos.

279 Equivalente, em grego, a arte manual, indústria, artesanato. Nossa expressão mais aproximada, em português, seria "técnica". 
Assim, ainda que possamos aludir, no plano da metáfora, às escadas, cotas de malha e ao aqualung como extensões da capacidade humana - sem falar nos amplificadores ópticos e acústicos - seu interesse enquanto utensílios não é de longe, tão grande, quanto a sua significância enquanto Tecnologias da Inteligência (LÉVY, 1993), isto é, enquanto manifestações concretas de um conhecimento previamente idealizado ${ }^{280}$.

Aliás, seja para o todo da Comunicação, seja especificamente para a MTE, as “extensões do homem" que mais nos interessam são justamente aquelas que expandem os limites do intelecto (e não do físico) humano, como a velocidade do raciocínio, o poder de cálculo, a contingência e a persistência da memória: referimo-nos às capacidades de ordem informacional.

Tais $\operatorname{artefatos}^{281}$, cujo ícone maior continua sendo a tecnologia digital, acrescentaram, efetivamente, novas dimensões ao universo do conhecimento humano e modificaram profundamente (não necessariamente para "melhor") o quadro social da pósmodernidade. A título de exemplos, poderíamos mencionar algumas dessas transformações:

(a) escala espacial - meios de comunicação contemporâneos podem estabelecer redes planetárias e até nos conectar a pontos longínquos do sistema solar;

(b) escala temporal - tais tecnologias podem, teoricamente, garantir a conservação integral e a inalterabilidade das informações por um tempo indefinido;

(c) volume - a quantidade de informação acumulada, bem como a capacidade de acumulá-la e processá-la, não encontra paralelo em períodos anteriores da história, além de crescer exponencialmente em ritmo alucinante;

(d) relações de poder - as tecnologias de comunicação tiverem seu desenvolvimento alavancado por necessidades militares, principalmente das duas Grandes Guerras em diante, beneficiando diretamente, no cenário geopolítico, os países e grupos

\footnotetext{
280 E levando em conta também, o papel que desempenham enquanto objetos culturais, conforme destacamos na seção final do capítulo III.

281 Termo que, como a maioria das expressões correntes não abarca o sentido do objeto de nossa discussão.
} 
envolvidos nessas pesquisas tecnológicas ${ }^{282}$. Por outro lado, o desenvolvimento destas mesmas pesquisas viu-se alavancado pela importância política e econômica (está cada vez mais difícil diferenciar uma e outra) que elas ostentam, num processo de feedback crescente;

(e) velocidade - o ritmo com que as transformações se sucedem, tanto no que toca às descobertas, quanto às aplicações, insere-no numa cultura de devenir constante. $\mathrm{O}$ mercado (sempre ele) incorporou esta tendência no sentido de promover o emprego quase descontrolado do princípio de descartabilidade, impondo a estratégia de obsolescência programada a todos setores produtivos - nos quais se inclui a produção de Comunicação/Informação.

Esta celeridade das mudanças e a própria fragmentação de nossos campos de conhecimentos (alguns incorporam melhor a interdisciplinaridade e a interdiscursividade que outros) conspiram para o entendimento diverso de todos os fenômenos envolvidos na questão tecnológica.

Também é de interesse assinalarmos que, pelo viés da dialética marxista

\begin{abstract}
“A revolução capitalista, a transformação da manufatura em produção mecanizada (...) na revolução industrial, e posteriormente o taylorismo, o fordismo, a automação e a robótica são considerados como a história da tecnologia na esfera produtiva: proporcionam os bens de capital cada vez mais complexos e os bens que constituem a tecnologia na esfera do consumo. As atividades humanas foram sempre mediadas pelas tecnologias, e isso acontece cada vez mais na vida doméstica e na cultura" (BOTTOMORE, 1988: 371).
\end{abstract}

Levando-se em conta todas essas reflexões preliminares sobre a "Tecnologia", adotamos aqui o conceito geral considerado por GRINSPUN (1999), de atividade humana "voltada para a prática, enquanto a ciência é voltada para as leis que a cultura obedece",283.

\footnotetext{
282 Sem muito esforço, podemos lembrar do rádio, do computador, dos satélites e da própria Internet, como tecnologias que devem muito de sua razão de existir - e de seus inúmeros vícios de origem, também -à sua importância estratégica militar.

283 Na verdade, ela toma emprestada a definição de Milton Vargas, expressa no livro Para uma Filosofia da Tecnologia (São Paulo, Alfa-Ômega, 1994).
} 
A mesma autora, ao comparar esta definição com outras ${ }^{284}$, destaca que ela deve ser entendida no contexto da sociedade moderna sem confundir-se com a já mencionada "Técnica".

A proeminência da tecnologia em relação aos outros aspectos mais "teóricos" da ciência é enganosa: o pensamento tecnológico caminha pari passu com as conquistas tecnológicas e, já o fazia mesmo antes da Revolução Industrial.

O texto de MORAIS $(2007,66)$ ajuda-nos a explicitar melhor como o pensamento tecnológico se imiscui na cultura social da contemporaneidade:

\begin{abstract}
"A Tecnologia, com sua contemporânea base científica, não se reduz a mecanismos e máquinas, no sentido palpável e concreto destes conceitos; abrange, isso sim, uma articulação de estruturações técnicas da vida social, que se constitui na dinâmica específica da sociedade industrial e até da que principia a ser chamada de pós-industrial. É o aspecto organizacional da técnica, com uma gama de valores peculiares, que a faz tão totalitária enquanto mentalidade, expandindo, pelo mundo, formas idênticas de produzir e de consumir; instalando um verdadeiro "esperanto social". As formas materiais da existência, nascidas do sonho de um mundo todo resolvido, passam, nesse caso específico, a "produzir" a consciência de vida dos seres humanos" (MORAIS, 2007: 66).
\end{abstract}

A gênese deste pensamento pode ser localizada na idéia do Homem Tecnológico de Victor Ferkiss, o qual, segundo ele, adviria da superação do paradigma industrial:

“É possível (...) argumentar que a querela sobre se o industrializo criou ou não uma sociedade de massa, que ameaça a liberdade humana, tornou-se sem sentido pelo desenvolvimento continuado da própria tecnologia. Quer dizer, a era industrial pode já estar em processo de substituição por uma nova fase na história humana, e o homem industrial, quaisquer que sejam as suas características, pode estar evoluindo rumo a algo diferente e superior - rumo ao homem tecnológico" (FERKISS, 1976: 58).

Um aspecto que não poderia ficar de fora nesta discussão contextualizadora da tecnologia ${ }^{285}$ no processo educomunicativo, é justamente o fato dela nos preocupar numa dimensão política, já que a MTE sempre foi objeto de controvérsia no universo da educação escolar ("nosso" universo de pesquisa). Lembremo-nos de que o educador Paulo Freire, alguns anos após ter alertado para o efeito "Cavalo de Tróia" inerente a alguns projetos de informatização escolar, registrou em um de seus últimos textos que

284 Vale destacar que o dicionário anglo-americano COLLIN $(2001,407)$ define technology como "aplicação de conhecimento científico aos processos industriais", inserindo-a, historicamente na modernidade industrial e, por conseqüência, ideologicamente, no sistema de produção capitalista.

285 Já que esta é, semântica e conceitualmente, o ponto fulcral em nossa análise. 
“A compreensão crítica da tecnologia, da qual a educação de que precisamos deve estar infundida, e a que vê nela uma intervenção crescentemente sofisticada no mundo a ser necessariamente submetida a crivo político e ético. Quanto maior vem sendo a importância da tecnologia hoje, tanto mais se afirma a necessidade de rigorosa vigilância ética sobre ela" (FREIRE, 2000: 102).

Anos depois, outros autores, como PISCITELLI seriam ainda mais enfáticos, afirmando que

\footnotetext{
"A capacidade de transformação não é algo intrínseco à tecnologia, mas imaginar que é - o filme que há mais de duas décadas Bill Gates e Nicholas Negroponte também querem nos vender — é o sonho (ou pesadelo) tecnocrático do fundamentalismo digital, frente ao qual devemos nos opor com firmeza e inteligência" (PISCITELLI, 2004: 58 - tradução nossa).
}

Reflexões apaixonadas à parte, este adendo necessário à reflexão pode fornecer um bom ponto de apoio para a nossa próxima discussão: como a Tecnologia e a Educação buscaram integrar-se na prática pedagógica, em sua dimensão mais ampla, e no universo da educação escolar, de uma forma mais específica.

\subsubsection{Integração das tecnologias na escola}

Tecnologia ou tecnologias? Uma questão já se coloca aqui, como preliminar ao subtema que nos propusemos a destrinçar.

Para efeito e uso geral - e sempre evitando avançar demais em debates que podem nos desviar do nosso assunto principal — nos limitaremos à seguinte demarcação:

(a) a Tecnologia, como designativo referente a um objeto de estudo científico transdisciplinar abrangente — sobre o qual alinhavamos diversas impressões no subitem anterior —, será grafado no texto com inicial maiúscula;

(b) as tecnologias, geralmente usadas para compor acrônimos como "TIs", "TICs" e "NTICs", serão consideradas designativos referentes às expressões pontuais e 
específicas (aplicações, soluções etc.) nas quais a Tecnologia se evidencia no contexto educativo.

Admitimos haver um certo grau de artificialidade nesta classificação ${ }^{286}$, mas a esta altura, um leitor mais perceptivo já deve ter identificado uma crítica inicial dirigida à visão instrumental que ainda predomina na relação entre Tecnologia e Educação. A esse respeito, podemos citar a crítica de CROCHIK (1998) que abarca no mesmo plano, desde o estudo dirigido por computadores até a metodologia construcionista (que analisaremos neste e no próximo capítulos), na afirmação de que "os objetivos visados por essas técnicas são iguais aos do ensino tradicional e visam a unidimensionalidade do pensamento, que, por si só, impede a emergência do indivíduo, pois não há negação da cultura e nem o resgate da crítica" (CROCHIK, 1998: 175).

A razão existente por detrás desta e de outras críticas fundamentadas, alimenta-se na divergência de valores e de objetivos entre os protagonistas que desenvolvem as "soluções tecnológicas" e os mediadores de processos educativos. Os primeiros, muitas vezes partem de um relacionamento protocolar tipo "cliente-fornecedor", embebendo-se pouco das demandas educacionais ou, pior ainda, amparando-se em modelos de práxis que há muito foram superados ${ }^{287}$.

Já os segundos, polarizam-se, muitas vezes, entre dois tipos de reação: ou a concordância com o modelo corporativo, no qual colocam-se no papel de um "cliente" aguardando um "produto" satisfatório; ou então, a rejeição pura e simples das soluções “empurradas goela abaixo" por "especialistas que nada entendem de educação". Ao longo de nossa experiência na prática educativa escolar, anotamos um sem número de vezes em que prevaleceu esta dinâmica de "diálogo entre surdos".

O podemos verificar é que, no decorrer de poucas décadas, os métodos e, principalmente as "ferramentas concretas" — físicas e lógicas ${ }^{288}$ — desenvolvidas pela

\footnotetext{
286 Provavelmente, trata-se de outra discussão superada ou em vias de superação.

287 De nossa parte, pudemos presenciar inúmeras vezes, processos de avaliação de softwares na escola pública, nos quais, um dos critérios de maior pontuação era a semelhança entre a interface dos programas e o universo de elementos tradicionais da escola, como a lousa, o caderno e a apostila.

288 Relutamos em identificá-las simplificadamente com o binômio Hardware-Software, preferindo associá-las, respectivamente a "artefatos" e "procedimentos".
} 
Tecnologia, agregaram-se — já que "integraram-se” não parece ser o termo mais adequado — à prática educativa de modo desigual e, não raro, contraditório ${ }^{289}$.

Como resultado, podemos perceber duas modalidades distintas de problemas relacionados com a nomenclatura da MTE nos contextos educativos onde ela pode ser identificada:

(1) discrepância/concorrência de terminologias, quando as expressões oriundas, por vezes da Tecnologia e, por outras, da Educação - manifestam entendimentos diversos sobre o papel que cada uma delas assume (ou deveria assumir) nessa inter-relação. O emprego de expressões como "ensinoaprendizagem", “capacitação" e até "treinamento" para denominar os mesmos processos de formação docente pode ilustrar esta constatação;

(2) esvaziamento semântico de expressões comuns, utilizadas nos contextos da Tecnologia e também nos da Educação. O próprio conceito de "Novas Tecnologias" exemplifica esta vacuidade, pois, além de ser difícil definir uma tecnologia como realmente "nova", é muito improvável que, em vista deste critério de "novidade", ela permaneça nova por muito tempo.

As diferentes denominações empregadas para nomear processos semelhantes assim considerados pela constância de seus elementos componentes e similaridade das dinâmicas desenvolvidas entre eles — refletem a postura de um determinado campo de conhecimento hegemônico nos processos educacionais ou, pelo menos, de uma concepção que nele se origina.. Já a convergência atual entre tais concepções diferenciadas evidencia, por um lado, o anacronismo das divisões usualmente aceitas e, por outro, a imprecisão e volatilidade dos novos conceitos que se criam, também eles, a mercê das contingências.

Como já destacamos, em mais de uma oportunidade, o próprio ritmo vertiginoso do desenvolvimento da tecnologia tende a tornar obsoletos todos os conceitos e termos que a

289 O postulador-mor do construcionismo, diria que "A mudança de um instrumento para radicalmente subversivo na sala de aula para um obtuso instrumento de laboratório de computação não adveio de uma falta de conhecimento nem de uma falta de software. Eu o explico por uma inteligência inata da escola, que agiu como um organismo vivo defendendo-se de um corpo estranho" (PAPPERT, 1994: 42). 
ela se relacionem. Esta particularidade, no entanto, longe de mascarar, na verdade evidencia as relações ideológicas e filosóficas por detrás de expressões tão "puramente técnicas".

Tome-se como exemplo a expressão Processamento de Dados que, da origem da informática até o início da década de 1980, definia tão bem o trabalho especializado de armazenamento, classificação e difusão de informações através de computadores. A expressão, que na essência definia apenas "seleção e operação sobre os dados para produzir informações úteis" (COLLIN, 2001: 113) caiu no mais completo desuso com a supremacia do conceito - muito mais abrangente e "expressivo" — da "Análise de Sistemas", que pode ser definido como a "análise de um processo ou sistema para ver se ele poderia ser executado mais eficientemente por um computador" (COLLIN, 2001: 403).

Esta chamada abordagem sistêmica, curiosamente foi encampada numa publicação da UNESCO redigida especificamente para introduzir os mediadores de processos educativos na lógica dos sistemas. Trata-se da brochura O Educador e a Abordagem Sistêmica, na qual consta que

\begin{abstract}
"a análise de situações muito mais corriqueiras também pode ser facilitada ou possibilitada por meio do raciocínio sistêmico sem que, para isso, sejam necessários conhecimentos especializados de informática ou de lógica formal. Com efeito, todos os factos sociais podem ser tratados nesta acepção sistemática ${ }^{290,}$ (UNESCO, 1989: 11).
\end{abstract}

Mais recentemente, embora a lógica ampliada da abordagem sistêmica não tenha sido de todo abandonada, já notamos claramente a influência do pensamento neoliberal quando se fala em “Gerenciamento de Informação”"291.

A própria expressão "Informática" (informatics), malgrado a grande diferença conceitual, disputou espaço, por algum tempo, com o termo "Cibernética" (cybernetics), antes de serem ambas as palavras, engolfadas pelo tsunami irresistível das Novas Tecnologias. Esta última designação mereceria, sem dúvida, um volumoso estudo à parte, tarefa que foge muito ao nosso escopo. Por esse motivo, a expressão de uso mais "genérico" aqui empregada para nomear o conjunto de recursos tecnológicos em uso

\footnotetext{
290 No contexto, sistema é "um conjunto dotado de um grau de complexidade maior que a das suas partes constitutivas — por causa das relações que as unem umas às outras." (UNESCO, 1989: 12).

Há uma tendência para migrar o protagonismo desta gestão para os próprios sistemas, isto é, deixar um mínimo de tarefas a cargo de cérebros humanos. Sem dúvida um progresso: se até ontem, as pessoas geriam máquinas, hoje são as máquinas que assumem a tarefa de gerir pessoas.
} 
corrente nos campos da educação e da comunicação será a de Tecnologias da Informação e da Comunicação (TIC), sobre a qual já nos referimos nos capítulos anteriores.

\subsubsection{Nomes diferentes para uma mesma idéia}

No contexto especificamente educativo (aquele que mais nos interessa, no momento) encontram-se hoje inúmeros conceitos e designações convivendo lado a lado e substituindo-se uns aos outros com tal facilidade, que seu esvaziamento torna-se óbvio.

A cada dia que passa, também são inventadas novas expressões, combinações de termos, neologismos e concepções "rizomáticas" (como diriam DELLEUZE \& GUATARI) que tentam (em geral, sem grande sucesso) se afirmar umas sobre as outras. Várias destas novidades originam-se do meio acadêmico mas é a imprensa (especializada e nãoespecializada) quem se encarrega de popularizar a maioria delas, sem necessariamente preservar-lhes o contexto.

Tais designativos (como a eles nos referiremos), usados correntemente com maior ou menor freqüência, parecem ter se desprendido diretamente do jargão de suas respectivas áreas (Tecnologia, Educação), o que justifica a importância e a pertinência de se analisá-las, uma vez que evidenciam, no mais das vezes, a procedência de suas matrizes epistêmicas.

Assim, podemos delinear claramente dois blocos diferenciadas que se orientam, ou em consonância com a visão da Pedagogia, ou regidas pelos ditames da Tecnologia (e por vezes, sem ultrapassar o nível da Técnica). São eles:
ABORDAGEM TECNOLOGICAMENTE ORIENTADA

\section{ABORDAGEM PEDAGOGICAMENTE} ORIENTADA
(a)Tecnologia Educativa
(c) Educação Tecnológica
(b) Computação Educativa
(d) Educação Midiática

quadro 25: abordagens pedagogicamente /tecnologicamente orientadas

Trataremos agora, com brevidade, da origem e desenvolvimento histórico desses designativos. 


\section{(a) Tecnologia Educativa}

Este é uma apresentação que se faz necessária, pois, a rigor, a relação entre a Tecnologia e a Educação, remonta à década de 1930, levando-se em conta o conceito de Tecnologia Educativa que, segundo MOREIRA (2000, 32) é "o conjunto de meios ou elementos mediadores e intencionalmente concebidos que interagem com a estrutura cognitiva dos sujeitos no âmbito da educação". Esta referência nos leva diretamente à B. F. Skinner ${ }^{292}$ e sua “máquina de ensinar", indicando a existência de todo um trajeto histórico a ser reconstituído, tarefa que, novamente, será contemplada em outra ocasião.

De qualquer forma, algumas informações podem ser de grande valia para que se compreenda o emprego de determinados designativos ao invés de outros.

É necessário, por exemplo, estabelecer uma distinção clara entre Tecnologia da Educação — sinônimo de Tecnologia Educacional (TE), centrada em conhecimentos e didáticas - e Tecnologia na Educação, que é a parte da TE que se ocupa das técnicas e dos materiais tecnológicos "manipuláveis" (MOREIRA, 2000).

Transpondo o conceito para um contexto mais contemporâneo, ALMEIDA nos fala de duas correntes principais de aplicação da Informática na Educação:

\footnotetext{
"A primeira grande linha conceitual sobre o uso da Informática na Educação teve início com o próprio ensino de informática e de computação. Posteriormente, surgiu uma segunda grande linha, com o objetivo de desenvolver o ensino de diferentes áreas do conhecimento por meio dos computadores — isto é, o ensino pela (grifo nosso) informática" (ALMEIDA, 2000: 23).
}

Assim, a maior parte dos designativos aqui analisados, se empregam para nomear modalidades de aplicação e estudo pertencentes não só ao âmbito da Tecnologia na Educação, como também à linha que usa a Informática para fins educativos.

É notável também, a ênfase que se dá nos dias de hoje ao aspecto informacional da tecnologia, sendo que, em alguns casos, as duas palavras — Tecnologia e Informática — chegam a serem empregadas como sinônimos.

292 Psicólogo americano considerado como o pai da teoria comportamentalista ou Behaviorista. A filosofia pedagógica instrucionista, que remonta aos primórdios do uso educativo da informática é claramente inspirada nos conceitos behavioristas de estímulo e reposta. 
Por um lado, é inegável que o computador representa o aspecto mais evidente (e onipresente) da tecnologia ${ }^{293}$, mas, por outro, sem a existência de uma estrutura de redes locais e mundiais - isto é, sem o aspecto comunicacional da tecnologia -, o conjunto hardware-software continuaria sendo um item de interesse bastante restrito dentro da Educação.

No que toca à Informática na Educação, contudo, mais do que uma oposição entre estruturas de interação off-line contra redes de computadores, o embate mais significativo que teve lugar nas duas últimas décadas foi entre os adeptos de duas correntes pedagógicas, os quais, diga-se de passagem, renegaram a "herança skineriana": os cognitivistas e os sócio-culturalistas.

Já tratamos, ao longo do trabalho e principalmente na Introdução, dos aspectos nebulosos que levaram a esta oposição, um tanto equivocada de nosso ponto de vista. Não obstante, o debate ainda persiste e precisa ser analisado.

De um lado, os cognitivistas, apoiados (com alguma distância) na "Epistemologia Genética" de Jean Piaget (PIAGET, 1977), entenderam que o desenvolvimento de ambientes pedagógicos como o LOGO $^{294}$ seria o melhor caminho para o emprego dos computadores na Educação e, do outro, os socioculturalistas, embasados (também longinquamente) nas idéias de Vigotsky (VIGOTSKY, 1998; 1999) insistiam na inutilidade de qualquer proposta pedagógica que não fosse centrada nas interações sociais dos alunos.

$\mathrm{Na}$ atualidade, podemos dizer que ambas as correntes se mesclaram ou, num juízo mais pessimista, que nenhuma das duas chegou a ser suficientemente assimilada ou devidamente revista. Não obstante, o foco da discussão crítica saiu do terreno das teorias instrumentalistas e psicopedagógicas para o do debate mais amplo, fundamentado na percepção crítica do modelo globalizado/globalizante que impõe a tecnologia como uma solução para qualquer problema, inclusive para os que nem sequer existem. No dizer de MORAES, “o computador pode se tornar apenas mais um 'modismo' da educação, cujos benefícios no que diz respeito ao avanço da qualidade educacional poderão ser muito duvidosos" (MORAES, 2000: 118). Tal pensamento, já anuncia um posicionamento crítico que eleva o nível do debate a um novo patamar.

293 A se confirmar a tendência atual de convergência tecnológica, logo ele estará literalmente em toda parte (celulares, relógios, eletrodomésticos, etc.).

294 Linguagem de programação desenvolvida no MIT (Massachussets Institute of Technology) pelo cientista Seymour Papert para que as crianças e adolescentes aprendessem a programar computadores. 


\section{(b) Computação Educativa}

Sob o nome de "Computação Educativa" ou "Informática Educativa", encontra-se uma série de linhas de ação que correspondem às diferentes maneiras da Tecnologia entender e oferecer soluções integradoras para o campo da Educação.

Tais soluções compõem um leque variável de tendências mais ou menos diretivas, mas que apresentam todas uma centralidade no processo de interação educando/computador.

Uma das primeiras correntes envolvidas nesta dinâmica e que vicejou com grande brilho nos primórdios da microcomputação é denominada $\boldsymbol{C A} \boldsymbol{I}^{295}$, ou, mal-traduzindo, Instrução Auxiliada por Computador.

Embora a proposta CAI nunca tenha assumido o papel de uma pedagogia, ela parece ser a razão de fundo de vagos temores sobre a substituição do professor por máquinas especializadas. Na verdade, a CAI quase sempre foi apresentada como alternativa didática para o aprendizado de tarefas simples e pontuais. O problema parece ter se constituído quando se propôs a "modernização" da escola com (ou pela?) adoção de recursos digitais que não estavam inseridos nas concepções educativas vigentes. $O$ resultado foi $o$ desenvolvimento de uma sistemática de atividades de orientação instrucionistacomportamentalista, num espaço onde já se propunha, há tempos, o paradigma da "construção do conhecimento".

Segundo ALMEIDA:

"Há uma gama enorme de programas de computador para uso em educação que têm como fundamento a teoria comportamentalista. São os programas denominados $\boldsymbol{C A I}$, que transmitem informações ao aluno - sujeito passivo - ou verificam o volume de conhecimentos específicos sobre determinado assunto que são 'depositados' na mente do aluno" (ALMEIDA, 2000: 27).

A preocupação com críticas desta natureza parece ter sido um dos motivos que levou ao desenvolvimento da proposta LOGO por Seymour Papert ${ }^{296}$ (PAPERT, 1994). Resumidamente, tratar-se-ia de colocar à disposição de crianças a possibilidade de aprender a programar computadores por meio de uma linguagem especialmente desenvolvida para esta finalidade e, através de uma metodologia não-linear nem rígida de resolução de

$295 \quad$ Computer Aided (or Assisted) Instruction (COLLIN, 2001: 63).

296 Matemático e cientista computacional de origem sul-africana, radicado nos EUA reconhecido pela iminência de seu trabalho junto ao já citado MIT. 
problemas. O professor, neste contexto, teria o seu papel limitado ao de um "facilitador" da aprendizagem, acompanhando o aluno e estimulando sua autonomia na "construção do conhecimento".

Esta filosofia de trabalho evocou, desde a origem, um embasamento piagetiano, autodenominando-se "Construcionismo", quase uma variação do "Construtivismo" de Piaget. Talvez, o construtivismo "papertiano" tenha sido o primeiro movimento educacional, oriundo do campo tecnológico, suficientemente organizado e fundamentado para criticar, com rigor e propriedade, as limitações da educação tradicional no que tange a se apropriar da Tecnologia. Um exemplo:

"As teorias que foram desenvolvidas por psicólogos educacionais e por psicólogos acadêmicos em geral correspondem a um tipo específico de aprendizagem, o tipo da Escola. Enquanto estes estilos de pensar sobre a aprendizagem permanecem dominantes, será muito difícil fazer um desvio sério da forma tradicional da Escola" (PAPPERT, 1994: 31).

O sucesso das idéias de Papert estendeu-se até o Hemisfério Sul e seu exemplo mais significativo talvez seja o Projeto Gênes $\boldsymbol{e}^{297}$, levado a cabo pela administração municipal de São Paulo e que adotou integralmente a metodologia construcionista ao longo da década de 1990. Não por acaso, o departamento responsável pelo suporte a esta área pedagógica foi denominado, por muito tempo, "Informática Educativa", antes de ser renomeado para "Setor de TICs.

Nunca faltaram, contudo, pontos de vista divergentes em relação à pertinência do LOGO num projeto pedagógico escolar. Além dos críticos contumazes à simples adoção de recursos tecnológicos no Ensino Fundamental ${ }^{298}$, há autores que não vêem grandes diferenças entre o LOGO e as iniciativas baseadas em CAI:

“(...) tanto as propostas C.A.I. quanto as propostas LOGO são meios de ensino de massa e, então, pode parecer paradoxal que proponham um ensino individualizado. Mas a máscara cai por terra quando se verifica que os objetivos visados por essas técnicas são iguais aos do ensino tradicional e visam à unidimensionalidade do pensamento, que, por si só, impede a emergência do indivíduo, pois não há negação da cultura e nem o resgate da crítica" (CROCHIK, 1998: 175).

297 Assessorado inicialmente pela Escola do Futuro da USP e, logo em seguida, pelo NIED (Núcleo de Informática Aplicada à Educação) da Unicamp de Campinas-SP (Cf. MENEZES, 1993).

298 O matemático Valdemar W. Setzer, já mencionado autor da obra Meios eletrônicos e educação: Uma visão alternativa.(São Paulo: Escrituras, 2001) é um exemplo emblemático desta linha. 
Um dado significativo que pode ajudar a compreender a dinâmica comum ao LOGO e as propostas CAI é o uso "adjetivo" dos termos referentes à Educação. Pode-se imaginar que a Tecnologia (Computação ou Informática) vem em primeiro lugar, trazendo a Educação a "reboque".

\section{(c) Educação Tecnológica}

Assim como o construtivismo de Seymour Papert buscou estabelecer uma ponte de diálogo entre os campos da Tecnologia e da Comunicação, na mão inversa, sempre existiram educadores ou grupos de educadores que se propuseram a incluir as questões tecnológicas como um ponto fundamental na pauta da Pedagogia.

Surgiu então o conceito de Educação Tecnológica, sobre o qual é preciso tecer algumas considerações.

Primeiramente, notemos que a expressão em português parece ter nascido na Europa, constando na obra de autores como REIS (1995), BAPTISTA (1993) e AZEVEDO (1991). Pelo teor das obras citadas livros, nota-se uma relação com a reforma do sistema educacional português, requisito tido como necessário para o ingresso daquela nação peninsular na Comunidade Européia.

O modelo que forneceu referências para esta reforma foi, sem dúvida, o sistema educacional inglês, e de fato, nas fontes citadas pelos referidos autores constam diversas obras da década anterior (1980) que ostentam em seus títulos título a expressão Technology

\section{Education.}

Se a genealogia da expressão pode ser relacionada com a escola européia, por outro lado, o designativo parece ter sido re-significado, também por uma reforma institucional, a dos CEFETs ${ }^{299}$.

Uma obra marcante é a compilação de textos organizada por GRINSPUN $(1999)^{300}$, na qual ela própria e outros co-autores - não por acaso integrantes, na ocasião, do corpo docente do CEFET-RJ - discorrem sobre as implicações históricas, filosóficas e sociais da Educação Tecnológica.

299 Centros Federais de Educação Tecnológica, escolas de Ensino Médio e Superior voltadas para formação na área tecnológica e administradas pelo Governo Federal.

$300 \quad$ A obra é Educação Tecnológica-Desafios e Perspectivas, publicada pela Editora Cortez em 1999. 
As posturas encampadas pelos estudiosos que empregam este designativo são unânimes em afirmar a necessidade de avaliação o papel social da tecnologia equilibrando questões éticas e práticas. Também é destacada a condição histórica atual de "mudança de paradigma educacional" de um modo consoante com os escritos de MORAES (1999) e que remetem, em última análise, às idéias de alcance planetário referentes á "Sociedade do Conhecimento"(LÉVY, 1993).

A Educação Tecnológica, pela perspectiva de Grinspun também não descuida dos aspectos organizacionais mais práticos, relativos à organização e gestão de programas formativos para alunos e docentes. Esta preocupação talvez reflita o vínculo governamental da iniciativa, que, mesmo estruturada de forma sólida parece não ter ainda conseguido no caso brasileiro - uma disseminação grande, quer junto a outras instâncias do governo, que junto aos centros acadêmicos de formação docente.

É necessário observar, no entanto, que o designativo "Educação Tecnológica" dá conta de exprimir a intenção de integrar a Tecnologia sem abrir mão da prerrogativa educacional na condução do processo. Por este viés, talvez, ela pudesse ser entendida como "Educação para entender e saber usar a tecnologia".

\section{(d) Educação Midiática}

O conceito de Formação em Mídias ou Formação Midiática aproxima-se — mas não se funde - com os de Estudos da Recepção, Media Literacy e Media Education que ocuparam posição central nas levadas a cabo no campo da Comunicação, principalmente entre as décadas de 1960-1980. De fato, muito do repertório acumulado por estas correntes, em termos de vivências e conhecimentos, embasou a implantação e gerência de projetos educativos posteriores.

Além do fato de, agora estarmos nivelados pelo parâmetro da hipermídia interativa, ressalta-se a posição marcadamente política das correntes mencionadas, às quais se contrapõe hoje uma certa aceitação tácita ou uma integração dos new media ${ }^{301}$.

\footnotetext{
301 Neste sentido, destoa bastante a postura do chamado Movimento do Software Livre (cf. SILVEIRA, 2004 e SILVEIRA \& CASSINO, 2003), curiosamente (e sintomaticamente) uma linha ativista de estudo - mas, fundamentalmente de intervenção - que emergiu justamente da área da Tecnologia. Este movimento se orienta pela defesa na liberdade de acesso e produção de informação digital, sem levar em conta a diferença entre mídias e analógicas e digitais. Na verdade, o que os defensores do Software Livre entendem, é que a Internet tornou-se a mídia "que conta".
} 
Neste ponto, não nos estenderemos mais na explanação sobre os postulados da Educação Midiática, uma vez que muitos deles se evidenciarão nas próximas páginas, culminando com a apresentação do ambiente e-Proinfo.

\subsection{O elemento Político-Pedagógico ou "um debate histórico"}

Para ilustrar a importância da relação entre o pensamento político na MTE e a adoção de modelos de projeto pedagógico, apresentaremos um relato pontual que sintetiza muitas constatações a esse respeito.

Em novembro de 1995, no campus da PUC-SP, teve lugar um debate histórico em que se contrapuseram as idéias de Paulo Freire - o grande alfabetizador de adultos - e as de Seymour Papert - especialista em do MIT que advogava a revolução escolar a partir das crianças e por meio das máquinas ${ }^{302}$.

É interessante observar, de princípio, que este debate ocorreu dois anos após a prefeitura de Luiza Erundina, durante a qual deu-se a passagem de Freire pela pasta municipal da Educação de São Paulo ${ }^{303}$. Um dos fatos mais marcante dessa gestão, para o escopo de nosso trabalho, é a implantação do já citado Projeto Gênese, uma iniciativa pioneira de informatização escolar implantada com a assessoria de pesquisadores do NIEDUnicamp e da Escola do Futuro-USP, obedecendo rigorosamente a proposta construcionista $^{304}$ desenvolvida por Seymour Papert.

Hoje, sob a perspectiva histórica, é possível analisar e comentar este debate emblemático sob a perspectiva da diferença de opiniões, embora, nas várias exibições públicas que pudemos presenciar (sempre com o objetivo específico de formação docente) o registro em vídeo do debate tenha sido apresentado como um exemplo de conciliação/aceitação da filosofia freireana em relação às concepções cognitivistas.

\footnotetext{
302 Esta sua abordagem, que sofreria algumas transformações ao longo do tempo, está particularmente bem ilustrada na obra "A Máquina das Crianças".

303 Cf. na bibliografia eletrônica MORENO \& DEL ROSSO (1995).

304 Recomendamos a leitura da separata de José Armando Valente Diferentes usos do computador na educação, disponível para download em http://nied.unicamp.br .
} 
Logo no início do registro ${ }^{305}$, após algumas preliminares mutuamente elogiosas, nas quais Papert afirma ter "aprendido tudo" com Freire, o qual, na seqüência, tenta dar uma interpretação à "piada epistemológica"306 alinhando-a com o conceito de educação bancária.

Ato contínuo, antes mesmo que Freire se desculpe por aproveitar a introdução do colega para fazer seu discurso, o americano retoma a explanação expondo sua leitura particular da Epistemologia Genética de Piaget, na qual ele equipara os estágios SensórioMotor e Pré-Operatório às fases pré-escolar e escolar.

O cerne da questão, para Papert, reside na auto-orientação, presente em origem na criança e que é sufocada pela escola, no momento em que os adultos a impedem de aprender por sua própria experimentação e lhe impõem um fluxo "bancário" de conhecimento. O que o cientista do MIT coloca como "The Big Break", ou a grande ruptura neste processo, é o fato de que, nos dias de hoje, o segundo estágio já não precisa ser uma obrigação, uma vez que o saber humano (sic) pode chegar ao domínio da criança, ao ritmo e na medida de sua curiosidade e interesse, por meio da Tecnologia. Ao final de sua exposição, ele é taxativo ao dizer que "Nada é mais ridículo que a idéia da tecnologia que a tecnologia possa ser utilizada para melhorar a escola: isso irá substituir a escola que conhecemos".

Após o impacto inicial das declarações papertianas, Freire parte dos exemplos de seus familiares que dominam a tecnologia (anteriormente, Papert havia ilustrado seu discurso com a familiaridade de seu neto de três anos com o vídeocassete) para diferenciar este universo (ou "classe social") do grosso da população brasileira em idade escolar. Segundo o educador pernambucano, em vinte ou trinta anos - tempo previsto por Papert para o "fim da escola" - estes milhões de meninos brasileiros estarão ainda mais distantes da tecnologia.

Freire afirma concordar com a crítica que Papert faz à escola, mas refuta a constatação de que ela sucumbirá, substituída pela tecnologia. Em suas palavras: "Para mim

\footnotetext{
305 Todos os comentários aqui referem-se à versão editada do vídeo que se encontra disponível para download na URL http://www.paulofreire.ufpb.br/, sob o título $O$ futuro da escola e o impacto dos novos meios de comunicação no modelo de escola atual.

306 Trata-se da conhecida anedota da criança que pergunta à professora, ao fim da aula, " - O que eu aprendi hoje?", e ante o estranhamento da mestra, esclarece que queria dar uma resposta satisfatória à pergunta que o pai lhe fazia diariamente e ela nunca sabia responder.
} 
a questão não é acabar com ela (a escola), é mudá-la completamente, é radicalmente fazer que nasça dela, de um corpo que não corresponde mais à verdade tecnológica do mundo, um novo ser, tão atual quanto a tecnologia” (MORENO \& DEL ROSSO, 1995) .

Após uma digressão histórica sobre a origem da linguagem e da cultura, Freire lança o axioma de que "Aprendemos antes de ensinar", complementando ainda que "Foi exatamente a constatação de que aprendíamos sem ensinar, que nos ensinou a ensinar" e finaliza o raciocínio concluindo que os equívocos da escola não são didáticos ou metodológicos, mas "políticos”, pois "O que tem de mudar, é o Poder".

Tergiversando sobre as críticas de Paulo Freire que colocam o discurso liberal como o grande mantenedor do segundo estágio, Papert tenta chegar a um denominador comum entre suas idéias e as de Freire, só para se deparar com as discordâncias aparentemente incontornáveis sobre a qualidade essencialmente ruim da (instituição) escola e sobre a possibilidade de se operar politicamente no sentido de melhorá-la.

Em dado momento, Freire resume a situação dizendo que ele e Papert "caminham juntos só até determinado ponto", mesmo querendo ambos, basicamente a mesma coisa. Freire atribui a divergência à abordagem diferenciada de ambos, que, a seu ver, é mais “metafísica” em Papert, enquanto define a sua própria como histórico-política.

Então, buscando uma visão mais conciliadora, Papert passa a criticar o que chama de "liberalismo", identificando-o com o conservadorismo e a burocracia reinantes na escola tradicional ou não-alternativa (ele se refere à escola americana). Questionado sobre quem representaria o papel de agente da mudança pretendida - já que em sua obra ele parece delegar o papel aos alunos - Papert especula que a "revolução" poderá ser realizada por professores e pais dos alunos, que não se conformem com o atual estado de coisas.

Tentando aprofundar a discussão, Freire evoca o reprodutivismo de Althusser como fator que dificulta a mudança, principalmente por parte daqueles que servem ingenuamente a direita (em nenhum momento do debate Papert manifesta aderência à esta categoria de posicionamento político). Nos minutos seguintes, Freire, destaca a importância da escola como o ambiente onde se pratica a inserção na história e na cultura. Assim, a um tempo, ele justifica como as crianças contemporâneas - imersas na cultura e na história do computador - lidam naturalmente com a tecnologia mas, ao mesmo tempo, como elas não podem abrir mão da sistemática do conhecimento pela qual a escola deveria se responsabilizar. 
No bloco final, fica a impressão de que, como num típico "diálogo de surdos”, no qual cada interlocutor encerra agradecendo a contribuição epistemológica do outro, mas defendendo incisivamente seu próprio ponto de vista.

No caso, Freire fala em defesa da escola, dizendo que ela é imprescindível e que é possível transformá-la em numa boa escola. Já Papert, demonstra sua crença de que a tecnologia pode substituir a instituição escola e que, mais cedo ou mais tarde, o fará, por iniciativa de alunos, pais e professores (não necessariamente nessa ordem).

O que mais nos chama a atenção neste debate histórico, é que ele evidencia duas matrizes de pensamento dificilmente conciliáveis, mas que coexistiram num mesmo ecossistema educomunicativo — a rede municipal paulistana — durante mais de uma década. Dentro deste ecossistema desenvolveu-se um projeto local de mediação tecnológica que servirá como objeto para testar nossas categorias e instrumentos de análise em MTE.

\subsection{Sobre o mediador: o exemplo emblemático do $\mathrm{POIE}^{307}$}

O debate entre Freire e Papert, mais do que contrapor duas visões em que se identificam - em diferentes graus — orientações cognitivistas e sociointeracionistas, serve de introdução para colocarmos, do ponto de vista de nossa pesquisa, as peculiaridades concernentes à construção da Educação Midiática na educação pública brasileira.

Para dar prosseguimento à reconstrução desta trajetória, apresentaremos alguns elementos informativos que remetem à construção de projetos pioneiros de implantação das tecnologias digitais na escola pública. Tomaremos como modelo, um dos projetos pioneiros nesta vertente, nele apontando os fatos que se generalizariam em outros contextos.

Muitas das informações e opiniões aqui expressas, baseiam-se em nossa própria experiência pessoal ao longo de cinco anos, período em que desenvolvemos atividades de acompanhamento e intervenção direta sobre as referidas práticas de MTE na região do distrito de São Miguel Paulista (região Leste São Paulo, capital) e adjacências.

307 Sigla do cargo de Professor Orientador de Informática Educacional. 


\subsubsection{O Projeto Gênese e os primórdios da MTE na rede pública}

A Prefeitura Municipal de São Paulo foi um dos órgãos públicos pioneiros no Brasil a se preocupar com a implantação de redes computacionais na educação e também com a busca de uma filosofia pedagógica que sustentasse o uso educacional do computador.

Isso aconteceu na gestão (1989-1992) da prefeita Luzia Erundina que, como já referido, contava com Paulo Freire na pasta da Educação. Conforme relata MENEZES, uma das fundadoras do Projeto Gênese ${ }^{308}$ : “O projeto foi aprovado e publicado no diário oficial do Município, conforme Comunicado $n^{\circ}$ 21/92 de 12/12/1989, mas inicia-se somente em julho de 1990, a partir da preparação do primeiro curso de formação de educadores...” (MENEZES, 1993: 245).

A postura crítica de Freire em relação às tecnologias em geral, e as comunicativoeducacionais em especial, não parecia em princípio, propiciar um investimento entusiástico em computadores para as escolas. Surpreendentemente, por razões que mereceriam um estudo à parte, o projeto de informatização escolar, não só aconteceu num âmbito bastante significativo - cinqüenta escolas inicialmente - como ainda buscou a fundamentação sólida e bastante atual (na época) das idéias do cientista (também já referido) Seymour Papert, estudioso do MIT . Assim, além de um gasto considerável com equipamentos num período em que os computadores eram bem menos prosaicos, foi realizado também um grande investimento para garantir a formação dos professores para o uso das novas tecnologias.

\footnotetext{
"A formação dos professores fazia parte de um projeto político maior, onde se procurava assegurar ao professor uma visão teórico-prática sobre educação e currículo, envolvendo as teorias que fazem parte desta visão interacionistaconstrutivista e sócio-cultural, pois a orientação desta Secretaria era voltada para uma busca na melhoria da qualidade de ensino, que passa pela exigência de uma nova visão de construção de currículo, no caso, a interdisciplinaridade." (MENEZES, 1993: 246)
}

308 Que por sua vez derivou de uma iniciativa planejada ainda na administração do Prefeito Jânio Quadros (1985-1988), conhecida como Projeto Terceiro Milênio. 
As idéias de PAPERT continham um razoável grau de crítica à instituição escolar $^{309}$, além de se adequarem melhor dentro da realidade das escolas americanas que às brasileiras. Não obstante, seu processo de aceitação, disseminação e instrumentalização na forma de uma "abordagem construcionista" entre nós, pode ser considerado como muito bem-sucedido, como ilustram as colocações do pesquisador José A. Valente ${ }^{310}$, um dos responsáveis pela consolidação dessa metodologia, tendo atuado como assessor na implantação do projeto:

"A introdução do computador na educação tem provocado uma verdadeira revolução na nossa concepção de ensino e de aprendizagem. Primeiro, os computadores podem ser usados para ensinar. A quantidade de programas educacionais e as diferentes modalidades de uso do computador mostram que esta tecnologia pode ser bastante útil no processo de ensino-aprendizado" (VALENTE, 2002: 3).

O cerne da questão pode ser enfocado como a difícil conciliação dos dois princípios pedagógicos aparentemente antagônicos mencionados (cognitivismo/sociointeracionismo), mas, acima de possíveis divergências de epistemologia, o senso pragmático de um governo que não se propunha apenas a discutir, mas também a concretizar uma revolução educativa parece haver triunfado na decisão de se efetivar o Projeto Gênese.

Um aspecto cabal desta problemática é a própria existência de um profissional acumulando as funções de organizador, formador e executor de atividades didáticas. Outro aspecto não menos importante foi a opção de se concentrar os computadores num Laboratório de Informática Educativa (LIE), estabelecendo um espaço e uma grade horária determinados para as atividades da informática educativa.

Vamos nos estender um pouco na análise da figura do Professor Orientador de Informática Educacional, por entender que assim, identificamos elementos — basicamente de natureza político-legalista — que influenciariam posteriormente (como modelo) muitos outros contextos nos quais se exerceu a MTE.

\footnotetext{
$309 \quad$ Eis um exemplo transcrito: “As teorias que foram desenvolvidas por psicólogos educacionais e por psicólogos acadêmicos em geral correspondem a um tipo específico de aprendizagem, o tipo da Escola. Enquanto estes estilos de pensar sobre a aprendizagem permanecem dominantes, será muito difícil fazer um desvio sério da forma tradicional da Escola” (PAPERT, 1994: 31).

310 Trata-se de um engenheiro e estudioso das TEs ligado ao Núcleo de Informática Educativa (NIED) da UNICAMP e reconhecido entusiasta da informatização educacional.
} 
Ao longo de seus onze artigos, a portaria especifica que determina a estrutura e a dinâmica do projeto informacional da rede municipal (SÃO PAULO, 1997), destacas as obrigações do POIE, mas trata também com bastante ingerência sobre praticamente todos os aspectos ligados à informática educativa. Ou seja, ao mesmo tempo eu que se propõe a autonomia do mediador, suas opções de escolha são delimitadas coercitivamente ${ }^{311}$.

Em seus tópicos mais importantes (incisos de "b" a "f") o documento não recomenda - mas antes, determina - a opção "pela metodologia em que a criança programe o computador", pela utilização do "computador como instrumento, contribuindo para o desenvolvimento dos processos mentais, essencialmente de maneira conceitual" e como possibilidade de se obter, por meio do computador, "uma nova abordagem concreta de conhecimentos" ${ }^{312}$.

As funções a serem cumpridas pelo POIE são descritas num conjunto de quinze incisos, cujo teor poderia ser distribuído em cinco modalidades: (1) planejamento e execução das atividades pedagógicas da informática educativa; (2) suporte técnico e pedagógico das atividades desenvolvidas no LIE; (3) formação docente e autoformação; (4) organização e apoio a eventos pertinentes a sua área e (5) registro e relatório das atividades.

Tais funções cobrem a quase totalidade das possíveis atuações de um mediador em contexto de MTE, com a exceção de um aspecto decisivo: a integração - a priori e não, $a$ posteriori - desse trabalho no âmbito do projeto pedagógico da escola. É bem verdade que esta postura tecnologicamente segregacionista reflete um dado momento histórico da MTE, mas o fato é que esta concepção, em grande parte dos casos ainda não foi superada.

A esta altura, carecemos de algumas colocações que interliguem a reconstituição que buscamos proceder a respeito da MTE, desde as origens (contexto internacional, projetos pioneiros) até o estado-de-arte que ela apresenta nos dias de hoje (modalidades de educação virtual e interativa). Até agora, tentamos expor uma série de elementos que, por si só, não se conectam sistemicamente para alargar a compreensão sobre nosso objeto de estudo, mas que, para tanto, necessitam de nossa referida contextualização.

\footnotetext{
311 Embora se trate de documento legal, é curioso observar a proposição (por decreto) da orientação pedagógica construtivista-construcionista evidenciada pelo jargão assinalado. Aparece inclusive, no inciso " $\mathrm{f}$ " da portaria uma menção à “explorar micromundos”, numa ilusão clara a uma versão comercial específica do ambiente LOGO. É fácil entender que se trata de um dispositivo legal destinado, antes de tudo, a disseminar o uso do LOGO nas escolas da rede, priorizando-o em relação a todas as outras possibilidades de MTE.

312 Os grifos são nossos.
} 
Assim, incluir a análise de alguns fatores políticos relevantes, neste estudo, é para nós um passo na direção de entender os fenômenos sociais dos quais falamos — mas é preciso ir além. Entendemos que a interpretação que justifica nosso interesse pela MTE justifica-se pela (re-)construção de uma ou mais abordagens desta enquanto fenômeno pertinente à uma determinada realidade que tenta se impor hegemonicamente.

Tal(is) abordagem(ens), ou visão de mundo ${ }^{313}$, caracteriza-se não só pela forma de entender as relações mediativas entre Tecnologia, Educação e Comunicação, mas também por um modus operandi que é, verdadeiramente, sua expressão atitudinal concreta e transformadora da realidade. Caberia inclusive, uma aproximação entre este conceito e o de praxis educativa, tal como aparece na obra de Paulo Freire (FREIRE, 1992).

Assim ainda que num estágio "embrionário" podemos sugerir, didaticamente, que a implantação de projetos de MTE no Brasil, reflete e influência de duas visões ou concepções bem distintas as grandes concepções: (1) a Visão Pedagógico-Estatal e a (2) a Visão Tecno-Corporativa. Sem a pretensão de estender demais estes conceitos, nos limitaremos a colocá-los como parâmetros provisórios para auxiliar-nos no entendimento de nosso objeto de estudo.

\subsubsection{Visão “Público-Institucional” e Visão “Tecno-Corporativa”}

\section{(a) Visão Público-Institucional}

Desde o advento do que podemos considerar como "uma visão positivista" da educação, começou a ser construída uma compreensão educativa que incorpora como elementos básicos: (I) o papel da Educação como prática socializadora, normalmente ligada à preparação para o mundo do trabalho e instrumento de mobilidade social, o que acentua seu caráter democratizante; (II) a gestão da Educação como obrigação do Estado e (III) a Escola como espaço preferencial em que se exercem os processos educativos.

Esta visão Público-Institucional, caso a tomemos como hipótese de trabalho, remontaria suas origens, talvez, à Escolástica medieval (CAMBI, 1999), mas tendo

\footnotetext{
313 No sentido de que "Visão de mundo é a forma como entendemos a sociedade em que vivemos, são as crenças que orientam a nossa ação. É constituída pela leitura que fazemos do mundo onde vivemos, pelas formas como organizamos nossa ação no mundo em que vivemos e pelos ideais que temos em relação ao como o mundo deveria ser" (GANDIN \& GANDIN, 2003: 82).
} 
adquirido força de lei por volta do século XIX (nas nações então mais desenvolvidas) institucionalizou-se - em todas as acepções do termo - passando a ser reconhecida como a Escola. Embora tal conceituação possa transmitir um juízo de obsolescência e conservadorismo - tal como a vêem seus $\operatorname{críticos}^{314}$ (partidários da outra visão, mas também, pedagogos críticos $^{315}$ ) — de nossa parte, destacamos aqui justamente o caráter institucional e público que a escola assume e manifesta.

Em relação à MTE, esta visão agrega um elemento de prevenção (lembremo-nos de Freire e do "Cavalo-de-Tróia") e outro de assimilação, que acomoda e modela os aportes tecnológicos ao fazer escolar "rotineiro". O primeiro elemento, retarda a entrada das grandes inovações no espaço escolar, enquanto o segundo, atenua seu impacto, principalmente em alguns pontos sensíveis da hierarquia escolar, como o empoderamento do aluno. Por outro lado, como a própria hierarquia escolar determina, no caso dos processos de modernização por decreto - vide o caso aqui apresentado da rede municipal paulistana — o elemento de assimilação acaba sobrepujando o de prevenção.

Entretanto, as tendências em MTE não são delineadas apenas por forças que interagem intrinsecamente no âmbito da escola.

\section{(b) Visão Tecno-Corporativa}

Mesmo que, no moderno Estado de Direito, a escola formal tenha se consolidado como a instituição social encarregada da educação, a própria lógica acumulativa do capitalismo logo entendeu que o dever do Estado de educar não era incompatível com o direito privado da venda de serviços - inclusive os pertinentes à educação.

Assim, por sua vez, uma associação entre o setor corporativo empresarial e as instâncias de racionalidade técnica que o sustentam, também começou a construir sua própria compreensão sobre o papel da educação na sociedade. Esta, baseia-se nos seguintes princípios: (I) a Educação como prática de integração social voltada para a atividade

314 No dizer de PAPERT "O problema na educação apresenta um elemento adicional. A maioria dos conservadores honestos está trancada na suposição de que o estilo da Escola é o único estilo, pois jamais viram ou imaginaram alternativas convincentes para a capacidade de comunicar determinado tipo de conhecimento" (PAPERT: 1994, 18).

315 DALMÁS assinala que "A escola é um segmento da sociedade. E com esta aquela está comprometida na manutenção dos esquemas relacionais do mundo atual. Em outras palavras, a escola está comprometida com a continuidade das relações de dominação e de exploração vigentes, alimentando, constantemente, a opressão e a injustiça" (DALMÁS, 2005: 28). 
produtiva; (II) aceitação da gerência de eficácia e eficiência como parâmetros de qualidade e indicativos o êxito no processo educativo. Em acréscimo, a primazia do conhecimento técnico sobre o humanístico; (III) valorização da livre concorrência e da competição, acentuando seu caráter elitista; (IV) a gestão privada autônoma da Educação, se possível, com um mínimo de interferência do Estado e (V) a Escola como espaço em que se exercem os processos educativos, mas com a possibilidade de complementação ou mesmo alternância de prerrogativas com os meios de comunicação.

Mais uma vez nos deparamos com um quadro movediço pois, se há muita preocupação no meio pedagógico com a ingerência pedagógica deste pensamento, como transparece na afirmação de que “(...) esse novo discurso da qualidade total [e sua conseqüente metodologia] tem por trás de si uma visão do mundo neoliberal, que trás para a educação a lógica do mercado capitalista"316 (GANDIN \& GANDIN, 2003: 72); há também um outro lado a considerar, já que a transposição dos valores corporativos para a educação desperta nos educadores sentimentos tanto de adesão quanto de repulsa, como assinala MACHADO:

"A adesão decorre da obviedade da maior parte dos argumentos utilizados: é necessário que tudo funcione bem, que os recursos humanos e materiais sejam otimizados, que a felicidade esteja presente nos ambientes de trabalho, além de outras máximas acacianas. Com freqüência a repulsa está associada a uma visão dualista, que pretende separar radicalmente os universos em questão, fixando balizas nítidas entre o mundo da escola e o das empresas, entre os valores morais e os econômicos, entre os interesses do cidadão e as motivações dos empresários , entre o sagrado e o profano" (MACHADO, 2002: 45).

Em relação à MTE, esta visão sustenta uma função redentora e coloca os new media, não raro, como uma panacéia. Outra contradição notável é entre o reformismo apregoado no discurso de "uma nova escola para o mundo do século XXI" e o conservadorismo de conteúdo e forma na maior parte das soluções oferecidas pela pedagogia digital.

316 FREIRE é ainda mais incisivo quando diz que "A visão pragmático-tecnicista, contida em discursos reacionariamente pós-modernos, o que vale é a transferência de saberes técnicos, instrumentais com que se assegure boa produtividade ao processo produtivo. Este tipo de pragmatismo neoliberal a que mulheres e homens, ontem de esquerda, aderiram com entusiasmo se funda no seguinte raciocínio, nem sempre explícito: se já não há classes sociais, portanto seus conflitos também, se já não há ideologias, direita ou esquerda, se a globalização da economia não fez o mundo menor mas o tornou quase igual, a educação de que se precisa hoje não tem nada a ver com sonhos, utopias, conscientização. Não tem nada que ver com ideologias, mas com saber técnico" (FREIRE: 2000, 95). 
O que se pode perceber, em termos de influência de uma e outra visão, é que ambas são adotadas por grupos sociais diferentes, polarizados até certo ponto entre o Estado e o Mercado, os quais servem como referência institucional para a sociedade que se constrói hoje. Como o Estado ainda é uma presença forte e o Mercado, não obstante seu poder, evidencia com muita clareza, também, suas debilidades, é cedo para prever um desfecho desse processo histórico complexo, embora possamos apostar com algum grau de certeza numa solução negociada.

O que apresentaremos, na seqüência, é a essência do projeto de MTE encampado pelo Ministério da Educação (MEC), cujos investimentos mais ambiciosos, na última década, visaram, além da preocupação em incluir digitalmente toda a rede escolar pública brasileira, estabelecer uma plataforma virtual e interativa que possibilite a formação em serviço dos educadores e, “assim que possível” a Educação Midiática dos alunos. O destaque recairá sobre o projeto e-Proinfo e o curso "Formação Continuada em Mídias na Educação" ${ }^{317}$.

\subsection{O MEC e as políticas públicas da MTE}

De uma forma ou de outra, todas as políticas públicas que direcionam a implantação e a gestão da MTE no Brasil são, em última análise, chanceladas — quando não concebidas — sob a égide da esfera federal da administração — vale dizer: pelo MEC. Quando mencionamos aqui o Projeto Gênese e ressaltamos sua importância como referência e como influência, somos obrigados a contextualizá-lo dentro de uma tendência educacional tecnicista (ou tecno-corporativa, segundo nossos próprios termos) internacionalista, centrada na formação de capital humano e que remonta desde a década de 1950 (MORAES, 2000). A evolução histórica desta linha, ao longo dos anos 1970-1980, levou à adoção do convênio MEC-USAID ${ }^{318}$, o qual definiu, a partir "de cima" (da perspectiva do Ensino Superior) o que viria a ser o projeto educacional brasileiro.

\footnotetext{
317 O material complementar deste projeto poderá ser encontrado na seção final desta tese, nos anexos.

318 A United States Agency for International Development se identifica como uma agência governamental independente do governo federal dos E.U.A., destinada a oferecer assistência econômica e humanitária em todo o mundo" (cf. http://brazil.usaid.gov/subarea.php?id=61).
} 
A década de 1980, particularmente, marcaria a divisão entre posições do MEC e da SEI (Secretaria Especial de Informática) ${ }^{319}$, sendo que o primeiro órgão abria-se aos princípios de modernização/internacionalização ditados pelo mercado, enquanto o segundo tentava manter uma orientação nacionalista amparada no pensamento estratégico de alguns setores militaristas. O fim da Guerra Fria e a revogação da reserva de mercado ${ }^{320}$ definiram os rumos que a questão tomaria, sendo que

"Paralelamente à criação da Comissão especial n.1: Informática e Educação [CE-IE n. 11/83], a Secretaria Geral do MEC apresenta as Diretrizes e Bases para o estabelecimento da Política de Informática no Setor Educação, Cultura e Desporto, as quais sintetizam o pensamento formado até então sobre o assunto" (MORAES, 2002: 101).

A partir de 1985, ficaram assim estabelecidas as principais diretrizes para atuação do MEC no que tange ao binômio Educação \& Tecnologia: (a) ensino de e para a informática; (b) informática na Educação e na pesquisa; (c) formação de recursos humanos; (d) organização de bancos de dados e divulgação das potencialidades do uso da informática e (e) criação de centros-piloto multidisciplinares de informática e Educação com uso de equipamento nacional, entre outros.

Ainda segundo MORAES (2002), com algumas variantes, tais diretrizes foram conservadas ao longo das diversas experiências e projetos nos quais o MEC esteve envolvido até o começo dos anos 1990, tais como o Centro de Informática Educativa (CENIFOR), o Projeto Brasileiro de Informática na Educação (EDUCOM) ${ }^{321}$ e o I Plano Nacional de Informática (PLANIN).

O foco da discussão pedagógica, na época, oscilava entre as tendências da Computação Educativa e da Educação Tecnológica, e aí se mantiveram, até a grande mudança de paradigma verificada quando da introdução da Internet no Brasil.

Assim, em meados da década de 1990, um novo desafio se colocava entre as prioridades do MEC: definir o papel da web dentro das políticas públicas de universalização

\footnotetext{
319 Respondendo diretamente ao Conselho de Segurança Nacional, a SEI foi criada, ainda nos anos 1970, como órgão executor da política que visava "criar uma indústria nacional de informática e a respectiva capacitação científica e tecnológica na área” (MORAES, 2000).

$320 \quad$ Legislação de cunho protecionista que havia sido sancionada pela lei 7232/84.

321 Nenhuma relação com os projetos ou a nomenclatura "Educom" utilizada pelo NCE-ECA/USP.
} 
do ensino e da formação docente. Admitindo que a primeira parte da tarefa tenha sido postergada, em parte, pela falta de recursos demandados pela rede pública, a resposta para atender á segunda demanda desencadeou o esforço que resultaria do desenvolvimento da plataforma virtual e-Proinfo.

\subsubsection{O e-Proinfo}

A própria designação do e-Proinfo, denota sua ligação original com o Programa nacional de Informática na Educação-ProInfo, criado pelo MEC através da portaria $\mathrm{N}^{\mathrm{o}} 522$ de abril de 1997. O que havia de inovador na concepção do programa, não estava relacionado ao objeto de suas preocupações — o uso pedagógico da informática na rede pública de ensino fundamental e médio ${ }^{322}$ — mas na política descentralizadora de estender a co-gestão das ações aos governos estaduais e municipais.

Formulado e implementado por meio do Departamento de Informática na Educação a Distância (DIED), o ProInfo contou com financiamento nacional do FNDE (Fundo Nacional de Desenvolvimento da Educação) e internacional do BID (Banco Interamericano de Desenvolvimento) e da UNESCO.

No ano de 2002, as ações relatadas do ProInfo foram alvo de uma avaliação externa que resultou na publicação do relatório de atividades que embasou algumas das colocações aqui expressas (cf. BRASIL, 2002). O relatório em questão coloca como objetivo geral do programa "introduzir no sistema público de ensino básico a telemática (tecnologias de telecomunicação e informática) como ferramenta de apoio ao processo de ensinoaprendizagem" (BRASIL, 2002), e como objetivos específicos (a) melhorar a qualidade do processo de ensino-aprendizagem; (b) propiciar uma educação voltada para o desenvolvimento científico e tecnológico; (c) preparar o aluno para o exercício da cidadania e (d) valorizar o professor.

Este enunciado de intenções — principalmente na referência à "Telemática" — parece transportado diretamente da década anterior, não permitindo entrever com clareza

\footnotetext{
322 O que incluía até a entrega de equipamentos (cf.: http://portal.mec.gov.br/seed/).
} 
dois dos aspectos mais importantes (em nossa percepção) que concernem ao desenvolvimento da plataforma virtual e interativa para EaD e-Proinfo:

(1) a opção pela Educação Midiática como abordagem pedagógica, cuja manifestação mais emblemática pode ser considerada justamente o curso "Formação Continuada em Mídias na Educação”, o qual será abordado no próximo subitem;

(2) a adoção por uma plataforma aberta, a qual não só "permite a", mas "implica na" co-gestão do projeto pelas entidades participantes ${ }^{323}$.

O mesmo relatório de avaliação do Proinfo apresenta o e-Proinfo como

"um ambiente virtual de apoio ao processo ensino-aprendizagem em Tecnologia Internet, que permite concepção, implantação e operacionalização de uma infraestrutura completa para criação, condução e administração de ambientes de aprendizagem, tais como cursos a distância, complementos a distância para cursos presenciais, projetos de pesquisa, projetos colaborativos e diversas outras formas de apoio remoto ao processo ensino-aprendizagem" (BRASIL, 2002 ).

O e-Proinfo pode, então ser entendido como o resultado de cerca de uma década de investimentos do MEC no desenvolvimento de uma plataforma de EaD poderosa, flexível e aberta, a ponto de hospedar projetos de formação de educadores e alunos em escala nacional. Até certo ponto, o objetivo foi cumprido, na medida em que vários recursos similares aos de soluções EaD "proprietárias" 324 e uma disponibilidade muito maior. O outro lado da questão, no entanto, diz respeito às contingências inerentes aos projetos governamentais de longo fôlego, das quais o e-Proinfo não conseguiu se furtar:

a. observância de princípios centralizadores numa proposta metodológica inovadora, a qual se manifesta pela organização hierarquicamente orientada do ambiente ${ }^{325}$;

b. defasagem tecnológica, já que a estrutura básica do ambiente manteve-se ao longo de todo o seu desenvolvimento, adicionando-se novos recursos por agregação. Em

323 Teoricamente, uma plataforma aberta permite a hospedagem do curso e o desenvolvimento dos conteúdos em parceria com qualquer entidade interessada, estatal ou privada.

$324 \quad$ Isto é: de patente fechada, cujo uso implica no pagamento de royalties ao desenvolvedor.

325 É notório que, na época em que foi concebido, uma das maiores preocupações referentes aos ambientes de rede - fruto de uma clara influência tecno-corporativa — era a de definir "níveis de poder" (privilégios de administração) diferenciados para cada mediador. Embora do ponto de vista técnico isto possa ser considerado um recurso interessante, nele reside uma incompatibilidade com as concepções pedagógicas libertárias e democráticas que, idealmente, norteariam esta nova fase histórica da MTE. 
conseqüência, a intuitividade da interface ${ }^{326}$ foi sacrificada, exigindo dos novos usuários um período grande de familiarização e uma atenção constante para se evitar erros de funcionamento. Existem no ambiente tarefas simples que demandam operações trabalhosas (para a inserção de conteúdos, principalmente) e relatos freqüentes de inconsistências — "coisas que somem", indisponibilidade de recursos — por parte dos usuários ${ }^{327}$;

c. falta de investimentos complementares em $\mathbf{E a D}$, uma vez que o exercício efetivo da MTE a distância requer a coordenação de um conjunto complexo de fatores, tais como (no mínimo) máquinas e redes atualizadas, alfabetização tecnológica dos educadores e discussão prévia sobre o papel da tecnologia no Projeto Político Pedagógico (PPP) das escolas.

Após esta sucinta análise da plataforma e-Proinfo, passaremos à análise de um curso nele desenvolvido enquanto exemplo prático de MTE.

\subsubsection{O curso "Formação Continuada em Mídias na Educação”}

Podemos dizer que sempre existe uma diferença substancial entre a mediação possível — prevista - e aquela efetivada, na prática. Se tomarmos o curso em questão como um exemplo a ser analisado pelo modelo proposto em nosso capítulo III (a Metáfora da Orquestra), cabe antes caracterizá-lo. Por questão de praticidade, nos referiremos a ele na seção final deste capítulo, como o "Curso Mídias na Educação".

Ele pode ser definido como um curso modular, construído dentro das especificidades da plataforma e-Proinfo de forma colaborativa por diversas instituições de ensino superior $^{328}$, voltado à formação docente na perspectiva da Educação Midiática.

\footnotetext{
326 Este é um fator crítico, já que falamos daquela quer seria a "porta de entrada" no exercício da MTE para vários educadores.

327 Seria injusto falar de incompetência dos quadros do MEC na manutenção do ambiente. É mais provável considerar a transferência de recursos técnicos do e-Proinfo para os novos projetos de EaD do MEC, como a UAB, baseada no ambiente de código aberto Moodle (ver http://uab.mec.gov.br/).

$328 \quad$ Na produção de conteúdos para a plataforma, participam universidades federais (por financiamento direto) e estaduais (por convênio) da maioria dos estados da Federação. No caso específico aqui analisado a edição do curso no estado de São Paulo — não só a produção de parte dos conteúdos (equivalente ao módulo Rádio), mas a própria gestão, foram realizadas pelo NCE-ECA/USP em parceria com a Universidade
} 
$\mathrm{Na}$ verdade, referimo-nos aqui a edições do curso Mídias na educação, já que ele foi desenvolvido, de forma escalonada, em caráter experimental para formação de tutores (2005), num formato de curso de extensão universitária (duas edições do módulo Básico 20072008). No calendário estabelecido pela SEED-MEC ${ }^{329}$. Há outras edições previstas no formato de aperfeiçoamento (módulo Intermediário) e especialização (módulo Avançado).

As metas do curso são ambiciosas, contemplando a formação de cerca de dez mil educadores em todo o Brasil, sendo cerca de 2.000 apenas no estado de São Paulo. Para atingilas, foi organizado um quadro gestor com cerca de 40 tutores (Administradores de Turma ${ }^{330}$ ) no módulo básico, geridos por um grupo de 08 coordenadores de tutoria (Administradores de Curso). A interface entre a instância de administração técnica (desempenhada pela SEEDMEC) e instância de administração pedagógica e de secretaria, é representada pelos Administradores de Entidade. Assim, ao longo de cerca de sete meses, os conteúdos e atividades previstos no curso foram propostos e acompanhados pela referida equipe. Já a inscrição e efetivação dos inscritos ficaram a cargo da entidade parceira Secretaria de Estado da Educação-SP, representada inicialmente pela FDE (Fundação para o Desenvolvimento Escolar) e, mais tarde, pela Coordenadoria de Estudos e Normas Pedagógicas (CENP).

Quanto ao curso propriamente dito, foi estruturado em seis módulos temáticos, a cada um dos quais corresponde uma "Mídia" ou linguagem midiática: (1) Integração das Mídias na Educação (introdutório de 30 horas), (2) Televisão, (3) Rádio, (4) Informática, (5) Material Impresso e (6) Gestão Integrada de Mídias (todos em formato básico com quinze horas de duração). Pedagogicamente, cada módulo possui início e um término, este demarcado pela realização de uma avaliação parcial, que indicava a possibilidade de promoção (ou não) ao módulo seguinte e seus respectivos conteúdos. A conclusão do curso dependia, não apenas da aprovação parcial de cada cursista ao final de cada módulo, segundo critérios de suficiência/insuficiência, mas também, a elaboração de um projeto de ação pedagógica

Federal de Pernambuco (UFPE, contando também com participação da Universidade Federal Rural de Pernambuco).

329 A Secretaria de Educação a Distância, criada pelo decreto $\mathrm{n}^{\mathrm{o}} 5.159$, de 28 de julho de 2004, revogado na íntegra e substituído pelo art. 26 do Decreto $n^{\circ} 6.320$, de 20 de dezembro de 2007. Entre outras atribuições, ela concentra a gestão de atividades dos projetos TVEscola (EaD via TV), Webeduc-RIVED (portal de conteúdo de cursos on-line) e Portal Domínio Público (conteúdos on-line de uso livre).

330 Esta denominação e as outras constantes entre parênteses "()" nesta página, correspondem à hierarquia administrativa inerente à estrutura do ambiente e-Proinfo. 
centrado no uso de uma ou mais linguagens midiáticas dentro do PPP da unidade escolarreferência do cursista ${ }^{331}$.

$\mathrm{O}$ quadro de tutores delineado pelo NCE-ECA/USP contemplou profissionais de formações distintas, em sua maioria, com experiência em projetos educomunicativos (ver capítulo I) mas não necessariamente, na EaD. Ao longo de um processo de formação um tanto breve e pontual, os tutores foram apresentados aos princípios da mediação em ambiente virtual interativo e também à concepção pedagógica assumida pelo curso do MEC/e-Proinfo. Esta, de acordo com o relatório parcial do projeto, apresentado ao MEC em 2007 (FADE, 2007), caracteriza-se como

“de caráter sociointeracionista, [e] pressupõe a autoria como característica essencial a uma aprendizagem autônoma e significativa. Pressupõe ainda que uma aprendizagem efetiva exige, por parte do professor, um esforço no sentido de diversificar as formas de disponibilizar a informação, bem como de apresentação da produção dos estudantes" (FADE, 2007).

Quanto à análise da MTE desenvolvida no âmbito do cruso "Formação em Mídias na Educação", podemos balizá-la em consonância com o modelo proposto em nosso capítulo III, exemplificado pela Metáfora da Orquestra. Dessa forma, referimo-nos a:

a) agentes mediadores: os tutores e coordenadores de tutoria, embora definidos por uma variedade de formação e atuação, balizaram-se no denominador comum da espistemologia da Educomunicação. Isso garantiu uma consonância de visão e discurso na mediação. Por sua vez, os cursistas, devendo arcar com a responsabilidade de "trazer o curso para dentro da escola", não ficaram restritos a um papel mediante: sua produção escrita e o feedback proporcionado aos tutores e aos seus colegas podem ser considerados de grande significância;

b) objeto da mediação: as linguagens midiáticas — e não somente o que delas consta no conteúdo do curso - representaram o verdadeiro objeto da mediação. Neste ponto, podemos considerar o emprego da Metacognição, uma vez que as mídias não se fizeram presentes só como temática, mas como veículo nessa pedagogia de projeto;

331 Cabe esclarecer que o cursista inscrito, além de professor atuante na rede pública, deveria ser indicado pela respectiva Coordenadoria de Ensino. 
c) objetivos da mediação: quanto à perspectiva de transformação qualitativa efetiva das práticas escolares, sabe-se que constitui um processo complexo envolvendo uma mediação duradoura exercida em conjunto por grande número de agentes. No escopo e âmbito propostos pelo curso, a autoria de projetos de produção em mídias como elemento articulardor do currículo é o que se almeja. A finalização de um projeto factível como item de avaliação é uma meta condizente com tal objetivo;

d) fluxos mediatórios: além do feedback ${ }^{332}$, já mencionado, observa-se que as relações no interior de um intricado quadro de responsabilidades distribuídas (tutoria pedagógica, gestão administrativa, suporte técnico) levantou várias questões que ainda necessitam de avaliação e depuração. Mais interessante, a possibilidade de integração da proposta do curso dentro dos projetos escolares, é um esforço mediatório que ainda deverá ser verificado da perspectiva dos cursistas e como tema de outras pesquisas;

e) espaço da mediação: podemos visualizar este item em duas dimensões, sendo a primeira, a comunidade virtual que se estabeleceu entre os tutores e cursistas, e de ambos com as outras instâncias de gestão. $\mathrm{O}$ espaço da mediação que se estabeleceu, com maior ou menor efetividade nas escolas representadas, pode ser analisado pela repercussão do curso e sua proposta no ecossistema comunicativo escolar. Vale dizer: esta seria a avaliação contextual — e a mais importante — dos objetivos do curso;

f) resultados da mediação: além da avaliação institucional do curso e da gestão expressa no alcance das metas de atendimento - e dos cursistas, atestada por critérios de suficiência/insuficiência no cumprimento das tarefas propostas, o que fica do curso é o registro documental que pode ser resgatado pela pesquisa acadêmica e (no devido tempo histórico) fundamentar novas e diferentes abordagens de MTE num panorama que, longe de se cristalizar, apenas se descortina.

De nossa parte, consideramos concluída esta breve análise e passamos às considerações finais.

\footnotetext{
332 O trabalho desenvolvido num ambiente virtual e interativo tem a vantagem de assegurar u registro constante e fiel de todas as informações publicadas em chats, e-mails e fóruns. Isto, no entanto, não diminui a ocorrência e a importância dos (diversos) problemas verificados ao longo do curso, mas fornece pistas conclusivas para saná-los ou evitá-los.
} 


\section{CAPÍTULO FINAL}

\section{Considerações Finais}




\section{Conclusões}

Convicção e dúvida, erro e verdade - são palavras vazias como uma bolha de ar. Irisada e opaca, essa bolha é a imagem de tua vida.

Omar Kháyyám: RUBÁYÁT

Sem desmerecer os padrões admitidos para a elaboração de trabalhos científicos em nosso meio, consideramos muito difícil falar em "conclusões" e mais ainda, em considerações "finais". É claro que vários manuais de metodologia nos esclarecem que tais adjetivos absolutistas devem ser entendidos em sentido lato e circunscrito no âmbito dentro do qual é proposto o trabalho.

Sentimos, no entanto, um leve desconforto advindo, talvez, da obrigação de se dizer o que não se disse ao longo do trabalho, de alinhavar um sentido que ficou perdido aqui ou acolá, ou de encerrar o trabalho com um gran finale. Parece-nos que o problema esteja menos no caráter obrigatório de um proverbial "fecho de ouro", do que na fragilidade autoimposta de excusar-se pelas falhas — e, portanto, expô-las — que de outra forma, talvez, passassem despercebidas.

Não obstante, chegamos ao capítulo final de nosso trabalho com a esperança, não apenas de haver cumprido as proposições enunciadas na Introdução, como também de oferecer ao possível leitor um ganho epistemológico que seja, efetivamente, uma contribuição concreta no entendimento e, se for o caso, no exercício da Mediação Tecnológica na Educação.

E a quem podemos chamar, exatamente, de nosso "possível leitor”?

Os trabalhos acadêmicos, como se sabe, não são a forma de literatura mais difundida em nosso país e mesmo os livros que se publicam como desdobramento ${ }^{333}$ desses trabalhos, raramente atingem grandes tiragens e nunca se tornam best sellers.

Por outro lado, o fato de saber, de antemão, que focamos um público seleto pesquisadores, professores, estudantes - não nos deixa mais despreocupados. Afinal, a exigência de tais leitores costuma ser proporcionalmente inversa ao seu reduzido percentual no todo da população.

333 Não nos parece certo referi-los como "subprodutos", já que esta expressão (e quase todas que partem do radical sub) tem um caráter depreciativo. 
Assim, eximidos dos interesses pelo (e do) mercado ${ }^{334}$, além do interesse próprio de nossos pares acadêmicos, que outro fator poderia motivar a leitura — ou pelo menos a consulta — à nossa pesquisa?

Em primeiro lugar, mesmo em posição suspeita para emitir juízos sobre o próprio trabalho, gostamos de pensar que ele transmite, de maneira clara, idéias que podem ser de valor para os "interessados em geral" - categoria de leitores que bem poderia ser incluída no Livro dos Seres Imaginários de Borges.

Sob uma perspectiva mais "séria", enxergamos nosso maior público potencial naquele leitor que, de antemão, já conhece em alguma medida a Educomunicação. Podemos dizer que é para esse interessado específico que escrevemos a maior parte das passagens neste volume. O consolo é que, a cada dia, o círculo de conhecedores do nosso campo emergente se amplia rapidamente.

Então, falemos do - e para - o educomunicador.

Para o educomunicador diletante ou em potencial, aquele que transita sem muito cuidado entre os campos distintos da Educação e da Comunicação, dentro e fora da escola, há referenciais necessários sobre os conceitos e experiências envolvendo a Educomunicação, muitos dos quais obtidos no decorrer dos projetos geridos pelo NCE. O capítulo I pode ser um ponto de partida, se não para concluir uma pesquisa, ao menos para iniciá-la.

No caso do educomunicador atuante e já consciente da importância e das possibilidades vinculadas ao nosso campo, quisemos demonstrar que ainda há lacunas a preencher, assim como espaço para relatar experiências inovadoras: talvez ele possa testar nosso modelo proposto para entendimento da mediação, destinando-lhe um uso instrumental ou até atestando sua inadequação à realidade prática. Nesse sentido os capítulos III e IV podem ser inspiradores.

Há ainda a possibilidade, a não excluir, de promover o debate entre a nossa e outras linhas de pesquisa, áreas de atuação e até campos do conhecimento que, não obstante suas orientações díspares, demonstrem interesse nas mesmas questões, seja por afinidade epistemológica/metodológica, seja pelo contraponto da discussão apaixonada. Nesse caso, recomendamos principalmente a leitura dos capítulos I, II e, talvez, destas conclusões.

334 O que, nos dias de hoje, não deixa de ser um tipo de façanha... 
Ficam assim, um tanto artificialmente dividido o universo de leitores que, esperamos, possam beneficiar-se do conteúdo de nosso texto, entre:

(1) aqueles em busca de referências conceituais e interessados na discussão que envolve Educação, Comunicação e Tecnologia e

(2) outros mais interessados (ainda que momentaneamente) em orientações práticas que possam ser adotadas em situações de MTE.

Para que estas expectativas possam, minimamente, se cumprir (ainda que não detectemos, no momento, perspectivas de aferir tal processo), nos propomos a fornecer um roteiro que auxilie no melhor aproveitamento das informações compiladas e reflexões desenvolvidas ao longo de nossas páginas.

Assim, buscamos assinalar de modo didático, seis "ordens de acesso possível" ao conteúdo produzido, não como um impeditivo para outros transcursos e avaliações, mas expressando de modo mais claro nossas intenções originais a respeito desse trabalho.

A estes percursos específicos que serão analisados na presente conclusão, denominaremos:
a) possíveis itinerários na leitura deste trabalho;
b) contribuições conceituais da pesquisa;
c) contribuições metodológicas da pesquisa;
d) tendências e pontos para desenvolvimento futuro; e
e) prováveis omissões e incompletudes.

É quase certo que a outro pesquisador, que não ao próprio autor, caberia melhor assumir a tarefa de mapear o conteúdo desta tese. Então, essa seção final poderia ser entendida não só como uma recapitulação, mas também como o esboço de um roteiro convidativo para futuras contribuições dos leitores. 


\section{Possíveis itinerários na leitura deste trabalho}

Esta tese pode ser metalingüisticamente entendida como uma mediação: a maneira como procuramos delimitar um trajeto, dispor as informações numa seqüência lógica e direcionar o raciocínio do leitor que se aventurar a ler estas dezenas de páginas, observa a mesma lógica que atribuímos ao processo mediatório (ver capítulo III). Neste caso, o mediador - este autor - exercita sua mediatividade com mais ênfase ainda, no fechamento das conclusões, momento em que sintetiza e atribui significado aos silogismos desenvolvidos ao longo do trabalho, buscando acentuar sua coesão ${ }^{335}$.

$\mathrm{Na}$ introdução deste capítulo, esboçamos algumas sugestões ligeiras para a leitura desta tese, mesmo cientes da generalidade que nelas era perceptível. Pois bem, é hora de estabelecermos alguns recortes, partindo do perfil do nosso hipotético leitor, ainda que um tanto mal-delineado.

Imaginamos, assim, haver leitores mais afeitos às questões da Comunicação, outros da Educação e outros, ainda, com interesse decididamente focado nas implicações tecnológicas que recaem sobre essas duas áreas.

Ao comunicador, identificado no estudante ou profissional que lida com a produção midiática ou estuda essa linguagem, não pode faltar uma boa noção histórica do trajeto paralelo que Comunicação e Educação traçaram ao longo do século XX. Seria um exercício interessante imaginar como seria um mundo no qual os meios chamados "de massa" houvessem cumprido as promessas implícitas de ampliar a justiça social e a democracia no mundo, reduzindo o abismo cultural entre as classes e as nações. O breve ensaio que inicia o capítulo IV pode fornecer algumas pistas para entender o processo histórico que conduziu ao "triunfo" do capitalismo e inaugurou a chamada era tecnológica.

Já ao educador, convicto de seu papel social e crítico em relação às mídias, cabe alertar para o fato de que o lado mais pernicioso da manipulação política na Comunicação não é aquele que se escancara à caça de audiência ${ }^{336}$ nos programas de auditório e reality shows. Há que se preocupar, na verdade, com as certezas entregues e aceitas sem questionamento, expressas no papel ou no boca-a-ouvido desde os tempos imemoriais,

335 Ela também será apresentada para uma banca avaliadora e esta será outra mediação, ao vivo e em tempo real, mas esta ainda é uma história a construir.

336 Na realidade, da verba dos anunciantes em potencial. 
muito antes da web, do macintosh, do transístor e até da luz elétrica. Sob este prisma, é fácil constatar que Comunicação e Educação sempre foram muito próximas e se irmanam no compromisso de construir uma sociedade de acordo com o tipo de ética que lhes é inerente.

Para tanto, é mister conhecer as teorias que fazem dialogar a epistemologia nos dois campos e identificar, tanto em um quanto em outro, o pano de fundo da cultura. Neste sentido, talvez a leitura do capítulo III possa ser interessante.

No caso do leitor cujo interesse esteja aglutinado em torno das questões suscitadas pela tecnologia e suas aplicações educativas, eu recomendaria, não só a pesquisa histórica e epistêmica, como também - ou principalmente - a leitura de textos que tratassem da mediação em todos os seus aspectos. Confesso que a reconstrução do conceito de mediar, da concretude do óbvio passando pelas construções abstratas dos filósofos e sociólogos, até o exercício prático da mediação, abala em certa medida as certezas do pensamento linear ${ }^{337}$.

Arriscamo-nos um pouco em dizer que o estudo da mediação lembra um pouco as postulações da nova física, nas quais o elétron é onda e também é partícula, ou de que um gato fechado numa caixa pode estar ao mesmo tempo morto e vivo.

De modo similar, a mediação pode ser entendida como uma ação, uma situação e até um lugar, mas o que permanece é a urgência em determinarmos “em que contextos mediamos” e “que tipo de mediação fazemos”.

Como sugestão final para um possível itinerário nesta leitura, propomos aos eventuais leitores, que se referenciem em eixos de interesse:

(1) a leitura acadêmica, traduzida como aquela que fazemos para fundamentar outros trabalhos, a título de consulta e, quando é o caso, selecionando exemplos para confirmação ou refutação de pontos de vista. A dificuldade nesse tipo de acesso, é reservar tempo para apreender a profundidade das idéias, uma vez que a habitual leitura "dinâmica" não permite avaliar a consistência e a coerência do texto de uma forma plena;

337 Talvez, ainda influenciados pelo caráter movediço destas reflexões, tenhamos optado pela epígrafe um tanto niilista desta seção final. 
(2) a leitura pedagógica, que se foca num interesse específico, algo que se queira aprender ou ensinar. Do ponto de vista dos professores, sempre é útil ter a mão algo como um "guia", cujas orientações possam ser aplicáveis no contexto da sala de aula. Em nossa opinião, tal aproveitamento dos trabalhos acadêmicos, ainda que parcial, longe de acusar algum demérito, é também uma justificativa válida para quem os escreve;

(3) a leitura informativa, que corresponde à busca por informações sobre um tema bastante específico. Um tema específico, como o desta tese, pode ou não ser publicado como artigo em periódicos especializados e, mesmo que o seja, seguirá alcançando um público restrito. No formato exato em que nosso trabalho se encontra, com certeza, não teria grandes chances de ser publicado como livro. Para que isso acontecesse, ele teria que ser adaptado ao novo formato, perdendo, em algum grau sua essência. Resta esperar que a disponibilização do mesmo ${ }^{338} \mathrm{em}$ um suporte virtual ofereça esta possibilidade de acesso e amplie o círculo no qual o tema é discutido; e

(4) a leitura analítico-crítica, a qual se caracteriza mais como um exercício de redação acadêmica - proposto, aliás, como tarefa em disciplinas de metodologia. Particularmente, achamos esta possibilidade interessante, mais ainda se resultar num feedback que aponte qualidades e/ou defeitos da tese. Afinal, pior que ter uma obra criticada, é produzir um texto que ninguém leia.

Podemos dizer que, nós mesmos, tivemos de seguir um roteiro pessoal de leitura para compor este minúsculo guia. Esse "trabalho depois do trabalho" permitiu algum distanciamento, o suficiente, acreditamos, para avaliar objetivamente (tanto quanto possível) o que representaria a presente tese em termos de contribuição para a área da Educomunicação e correlatas.

338 Evidentemente da versão pós-defesa, devidamente retificada com as contribuições da banca examinadora. 


\section{Contribuiç̧̃es conceituais da pesquisa}

Nossa preocupação inicial, em relação ao QTR estabelecido, era a de garantir, por um lado, que não faltassem nomes significativos comprometidos, direta ou indiretamente, com a questão da MTE e, por outro, que não houvesse fontes referenciais em excesso quase sempre um indício de dispersão investigativa do pesquisador - ainda que congruentes. Acima do primarismo acadêmico de tais temores, pairava a preocupação de que, além de dialogar entre si (falamos em "pontes conceituais em nossa Introdução"), tais referências pudessem complementar-se umas às outras, viabilizando a construção do painel transdisciplinar e transdiscursivo que julgamos indispensável neste trabalho.

Vamos seguir uma ordem próxima daquela que orientou o desenvolvimento de nossas idéias ao longo do texto. Começando pela Introdução e deixando de lado os relatos pessoais nos quais justificamos nosso interesse pelo tema, há dois pontos que vale a pena destacar.

Em primeiro lugar, destacamos a adoção do modelo proposto por LOPES (2003) como um esquema articulador da investigação. Utilizar o esquema orientado por “instâncias" (epistemológica, teórica, metódica e técnica) possibilitou, de saída, uma visão mais clara do encadeamento "Tema $\longrightarrow$ Problema $\longrightarrow$ Hipótese" que orientou os rumos da pesquisa.

O outro ponto importante, a nosso ver, é a primeira aproximação realizada no texto entre as idéias de Vigotsky e as de Paulo Freire. Com certeza, não se trata da primeira vez que alguém nota a proximidade entre os universos conceituais dos dois educadores, logo, se há algum mérito naquela preleção, ele é outro: localizarmos, dentro do quadro de referências teóricas nas quais a Educomunicação se apóia, um lugar definido para a teoria sociointeracionista. Notamos que, embora diversos autores ligados à Pedagogia ${ }^{339}$ sejam citados com alguma freqüência em textos de pesquisadores da Educomunicação, falta uma unidade por assim se dizer "orgânica" nessa linha de referências, e a tentativa de alcançar esta organicidade está presente em nossos objetivos.

339 Jean Piaget, Celestin Freinet e Janusz Korczak são os mais recorrentes. 
O capítulo I, por sua vez, além de oferecer uma releitura sintética ${ }^{340}$ dos pressupostos da Educomunicação, procurou relacionar todos os projetos significativos desenvolvidos pelo NCE-ECA/USP sob um ponto de vista analítico bastante pessoal. Como fonte sobre o tema, o capítulo apresenta limitações, pelo alcance restrito da abordagem. No entanto, ele pode ser de utilidade para quem busca uma visão geral, sucinta e relativamente atualizada.

No capítulo II, a preocupação maior foi a de reconstituir a trajetória do conceito de mediação pelo viés de sucessivas abordagens filosóficas, sociológicas e comunicacionais. Imaginamos que a menção à obra de Serrano faça justiça à importância desse autor espanhol, cuja obra pode ser considerada tão importante quanto a de Martín-Barbero para a Teoria das Mediações, embora seja muito menos citada que a deste último.

O "resgate" das contribuições de Vigotsky, levado a cabo no capítulo III, não é uma novidade, mas antes, uma reparação: já há tempos que a Psicologia, a Lingüística e principalmente, a Educação vem redescobrindo que as teorias do pesquisador bielo-russo - um conjunto volumoso e esparso de anotações e construções inferenciais - mantém grande atualidade e "alguma qualidade a mais" que lhes faculta, como estrutura, o diálogo com áreas distintas do conhecimento. A preocupação social que está na base da concepção pedagógica vigotskyana, também não foi afetada com a transformação do quadro político mundial no final do século XX: antes mesmo que o bloco soviético desmoronasse, o pensamento de Vigotsky já havia sido adotado pelo Ocidente, embora com alguns malentendidos (também mencionados no capítulo III) e uma ênfase excessiva nos aspectos instrumentais.

Tais descompassos, mais a presença extensiva de termos e expressões comuns à área de especialização de Vigotsky ${ }^{341}$, podem causar algum estranhamento àqueles afeitos apenas ao pensamento das Ciências Sociais. Dessa forma, expressões como "fossilização" e termos hoje banidos como "retardamento mental" talvez ofereçam alguma dificuldade inicial no tratamento e na avaliação crítica da teoria sociointeracionista em seu estado puro. Neste caso recomendamos, como leituras complementares, os sociointeracionistas contemporâneos, como Cole, Scribner e Gallimore \& Tharp.

\footnotetext{
$340 \quad$ Baseada no uso de quadros-resumo, principalmente.

341 A Psicologia Experimental da primeira metade do século XX.
} 
Outro ponto que pode dividir opiniões diz respeito ao papel desempenhado pela escolarização, o qual, na obra de Vigotsky é identificado com o próprio processo educativo. Esta postura, quase unânime à época de Vigotsky ${ }^{342}$, não é muito diferente daquela que seria sustentada, décadas mais tarde, por Paulo Freire.

Parece próprio da Educomunicação, entretanto, voltar-se para outros espaços (ecossistemas) educativos que não os escolares, afinal, muitas pesquisas que forneceram subsídios para consolidar o novo campo, estudaram realidades extra-escolares (ONGs, comunidades). Lembremos porém, que os projetos de grande monta do NCE-ECA/USP, foram todos direcionados para atender demandas da rede pública escolar, tendo como participantes muitos professores de formação e atuação "convencionais". Este já seria um motivo mais do que suficiente para estimular pesquisas educomunicativas que considerassem o professor, a rede escolar e suas práticas como objetos de estudo primordiais.

A segunda metade do capítulo III apresenta aquela que, talvez, seja a contribuição mais importante de nossa tese: a proposição de um modelo para entendimento da MTE construído a partir de referenciais aportados da Educação e da Comunicação. Mais do que criar metodologia e nomenclatura novas com a pretensão do pioneirismo, consideramos a tarefa como um instigante exercício de construção e desconstrução analítica.

Em relação ao conjunto da tese, o capítulo IV aparenta ser o mais independente. Nele, nosso esforço caminhou no sentido de introduzir o elemento Tecnologia na equação proposta pela MTE e, também, de demonstrar a aplicabilidade do modelo proposto, no capítulo III, a um projeto educomunicativo efetivamente realizado em ambiente virtual e interativo. A consistência do modelo analítico, não pode ser avaliada por sua aplicação em um único caso estudado, o que deixa uma margem bastante grande para eventuais desenvolvimentos futuros e, quiçá, contribuições e acréscimos ao trabalho aqui iniciado.

Finalizando, podemos assinalar que o trabalho de compor o nosso Quadro Teórico de Referência (QTR) consumiu um tempo e uma energia consideráveis, mas as sucessivas fases de depuração das obras (elas estão classificadas na bibliografia, de acordo com o uso que aqui se fez na tese) serviram como uma revisão bibliográfica.

342 Embora Maria Montesori já atuasse e as idéias de Dewey estivessem bastante difundidas, o reformismo escolar ainda não predominava na Europa. 


\section{Contribuições metodológicas da pesquisa}

Embora seja forçoso admitir que, de um modo geral, não nos libertamos do modelo clássico de desenvolvimento argumentativo Fundamentação $\longrightarrow$ Proposição $\longrightarrow$ Defesa, esteve presente, em vários momentos desta tese, a preocupação de oferecer uma abordagem diferenciada, principalmente a respeito da "questão mediativa".

Uma característica recorrente, que detectamos em vários trabalhos de autores distintos que se debruçaram para estudar o fenômeno da mediação, foi a aparente compulsão em re-semantizar o termo, que, por sinal, já foi usado à exaustão em correntes filosóficas tão diferentes quanto podem ser a lógica aristotélica e o marxismo. Ora, se uma expressão catalisa tanto a atenção dos pensadores, provavelmente, ela merece todo o estudo que se dedique a ela. Neste sentido, a mediação se parece um pouco com o conceito da Terceiridade na Semiótica, senão no princípio lógico ${ }^{343}$, ao menos na fractalidade caleidoscópica e intangível com que se amolda a diversos níveis e âmbitos, sempre encontrando um ponto de fuga para o infinito.

Mesmo que essa tentativa de lançar alguma luz sobre o conceito de mediação tenha ocupado um considerável espaço nesta tese, acreditamos que a preocupação central que motivou a escolha do tema foi outra: a necessidade de aproximar a Comunicação e a Educação a partir dos pontos de contato epistemologicamente compatíveis e/ou complementares. Por isso, procuramos manter a discussão, sempre que possível, projetada contra o pano de fundo da noção de cultura - a qual representa uma espécie de protocolo de comunicação, inteligível (ainda que em acepções, por vezes, muito diferentes) para educadores e comunicadores. Talvez necessitássemos fazer um mea culpa pela maneira um tanto superficial e incipiente pela qual conceituamos (conceituamos?) a cultura, mas o fato é que esta discussão foi evitada justamente pelo espaço que ela exigiria, dentro de um trabalho que decididamente, concentra seu foco em outras questões.

Por outro lado, temos a nossa Metáfora da Orquestra, que deve, inegavelmente sua razão de ser à nossa pregressa formação musical. Caberia perguntar a razão de tratá-la no item reservado para as contribuições metodológicas, e não as conceituais.

343 Sob determinado ponto de vista, talvez até o seja, mas nos manteremos fiéis à promessa de não invadir mais esse campo. 
Segundo nosso entendimento, e levando em conta a metodologia de LOPES (2003), existem quatro instâncias a trabalhar na visão global de um modelo metodológico em Comunicação Social:

(1) a instância epistemológica: que se reporta ao paradigma sob o qual se trabalha;

(2) a instância teórica: a qual corresponde uma determinada corrente teórica dentro da qual o trabalho se insere;

(3) a instância metódica: que opera com os dados em nível de abstrações e construtos para tratamento das informações; e

(4) a instância técnica: que operacionaliza a parte instrumental, como a recolha de dados.

Com base nestes postulados, é concebível um enquadramento dentro do qual a Metáfora da Orquestra atenda às quatro instâncias, da seguinte forma:

\begin{tabular}{|c|c|}
\hline $\begin{array}{l}\text { INSTÂNCIA } \\
\text { EPISTEMOLOGICA }\end{array}$ & $\begin{array}{l}\text { Há duas fases identificadas por Lopes (2003), e que } \\
\text { correspondem a duas operações distintas: } \\
\text { (1) a ruptura epistemológica, que ocorre quando a mediação deixa de } \\
\text { ser tomada como a relação entre os seres e é assumida como } \\
\text { representação; } \\
\text { (2) a reconstrução do objeto de estudo, que ocorre quando a } \\
\text { representação é esquematizada como um modelo que tenta, a seu } \\
\text { modo, identificar a natureza e os atributos implícitos na mediação. }\end{array}$ \\
\hline $\begin{array}{l}\text { INSTÂNCIA } \\
\text { TEÓRICA }\end{array}$ & $\begin{array}{l}\text { Também constituída por duas classes de operações: } \\
\text { (1) a formulação teórica do objeto, que é modelado ("tornado modelo") } \\
\text { para evidenciar (ou não) uma correspondência possível entre o } \\
\text { construto e os eventos do mundo "real"; } \\
\text { (2) a explicitação conceitual, que envolve a adequação - mais, ou } \\
\text { menos feliz - de conceitos/categorias tomadas de empréstimos às } \\
\text { correntes teóricas em que se buscou apoio. }\end{array}$ \\
\hline $\begin{array}{l}\text { INSTÂNCIA } \\
\text { METÓDICA }\end{array}$ & $\begin{array}{l}\text { Envolvendo: } \\
\text { (1) a exposição, na qual recorremos, por opção a quadros dialógicos } \\
\text { (pergunta-e-resposta) lastreados por diagramas; } \\
\text { (2) a causação, quando ligamos o modelo concebido teoricamente, } \\
\text { representado graficamente e exemplificado na analogia de uma situação } \\
\text { hipotética. }\end{array}$ \\
\hline $\begin{array}{l}\text { INSTÂNCIA } \\
\text { TÉCNICA }\end{array}$ & $\begin{array}{l}\text { Esta fase instrumental de teste e coleta de dados, } \\
\text { evidentemente precisa ser testada na prática, o que acarretaria } \\
\text { (1) a observação de situações em que o modelo pudesse colaborar com } \\
\text { a prática educomunicativa; } \\
\text { (2) os dados e informações obtidos pela observação da realidade, } \\
\text { fornecem o feedback no teste do modelo. }\end{array}$ \\
\hline
\end{tabular}

quadro 26: a metodologia de LOPES (2003) aplicada à Metáfora da Orquestra 


\section{Tendências e pontos para desenvolvimento futuro, possíveis omissões}

Não são poucos os pontos deixados em aberto ao longo deste trabalho, alguns em razão da falta de espaço, pois levariam a desenvolvimentos colaterais extremamente longos que nos fariam perder em meio a um emaranhado de construções possíveis. Outros caminhos não foram trilhados simplesmente por lacunas em nosso mapa conceitual, as quais, como se sabe, são inextingüíveis, visto que o cognoscível (podemos realmente falar em “cognoscível”, ou só em “descritível”?) só faz expandir os limites do incognoscível ${ }^{344}$.

Poderíamos dizer, até, do que faltou fazer "antes do trabalho": uma ligação maior entre os processos históricos de formação docente que acompanhamos junto à rede pública na última década - e todos os debates neles envolvidos - e as instâncias investigativas que hoje concentram nossa atenção. Uma coisa é certa: dificilmente um único trabalho, de um único pesquisador, conseguiria dar conta de tamanha empreitada.

Nesse caso, é melhor que relacionemos, no rol de nossos "lapsos conscientes", somente as lacunas que terminam e começam no escopo da tese.

Considerando que o capítulo I atendeu satisfatoriamente à sua finalidade de apresentar-nos o conceito da mediação, desde a provável gênese até as acepções ainda válidas (seria temeroso defini-las como "recentes"), admitimos que a comparação entre modelos idealizados de processos comunicativos e educativos no capítulo III não tenha atingido o mesmo nível de esgotamento virtual da questão. Na verdade, utilizamos para nosso estudo preliminar, uma gama maior de modelos concebidos pelos autores referenciados e também por outros. Ao final, optamos por apresentar somente os mais simples, ou menos embebidos do jargão específico do próprio campo-referência (à exceção da ZDP em quatro estágios), para tornar mais claro o processo de construção de nosso próprio modelo.

O papel da cultura, como observamos há pouco, para ser devidamente discutido na questão da MTE, deveria ser alvo de um levantamento inicial muito mais aprofundado pois, se há entendimentos diversos - mas não necessariamente incompatíveis - do que

\footnotetext{
344 Penso que a questão reside não na capacidade de cumprir a tarefa hercúlea, mas sim, de cumprir a tarefa proposta. Imagino ser esta a base do julgamento que a academia nos destinará.
} 
consideramos "Cultura" no interior de cada campo em separado nas Ciências Sociais, é de se esperar que as concepções da Educação e da Comunicação precisem ser conciliadas.

De forma semelhante, o conceito de Tecnologia oferece um grande desafio de enquadramento epistêmico, inclusive porque o número de estudiosos que faz dele um “cavalo de batalha" só faz aumentar a cada dia. Mesmo tendo já redigido uma Monografia de Especialização ${ }^{345}$ e uma Dissertação de Mestrado ${ }^{346}$ centradas na questão recorrente da Tecnologia na mediação de processos educativos, continuamos à procura (ou à espera) de um enquadramento epistêmico menos "proteiforme", ou menos condicionado por aquilo que Charles Fort ${ }^{347}$ chamaria de "a Nova Dominante".

As tarefas pendentes e urgentes que consideramos mais importantes, caberiam na ordem da operacionalização do que sabemos sobre a mediação pela prática dos mediadores. Imaginamos que, se existe um esforço investigativo que deva ser feito, ele deve ser canalizado para testar o modelo em situações reais de mediação e captar, no âmbito da realidade, o papel transformador social da praxis da Educomunicação.

$\mathrm{O}$ fato é que os questionamentos colocados acima, e mesmo as afirmações que fizemos, suscitam um número ainda maior de questões cuja complexidade só faz crescer a cada dia.

Finalmente, destacamos que a contribuição maior deste aporte filosófico e teórico, deriva na experiência prática acumulada pelo NCE em parcerias notadamente - mas não exclusivamente - com escolas do setor público de vários estados brasileiros.

Resta assinalar, para que não fique aqui a impressão de que esta pesquisa começa e acaba no esforço para consolidar o campo de Educomunicação, o fato de termos consciência de que este trabalho só ganhará o devido peso e reconhecimento acadêmicos, quando conseguir estabelecer um pleno diálogo com os demais campos de conhecimento envolvidos e disponibilizando seus levantamentos e conclusões para serem examinados pelo crivo destas outras abordagens.

345 A Cultura Tecnológica e as mudanças qualitativas em Educação, Monografia apresentada ao COGGEAE/ PUC-SP em 2000.

346 Avaliação de softwares na educação Musical, modalidade: percepção, Dissertação de Mestrado apresentada ao Instituto de Artes da UNESP em 2003.

347 Charles Hoy Fort, foi um jornalista e escritor estadunidense falecido em 1932 que se especializou em colecionar notícias bizarras, ou fatos estranhos que não se enquadravam no sistema de "crenças científicas" — ou Dominante - da época em que viveu. Segundo ele, ciclicamente, advinha uma "Nova Dominante", ou um novo conjunto de explicações científicas que tomava o lugar do anterior, que por sua vez, caía em descrédito e desuso. Uma antecipação a Thomas Kuhn? (FORT, N/C). 
REFERÊNCIAS 


\section{REFERÊNCIAS}

Optamos aqui por apontar nossas referências bibliográficas dividindo-as em quatro categorias orientadas principalmente, mas não exclusivamente, pelo modo como as relacionamos com o texto da tese. Assim temos: (a) Básica, (b) Específica, (c) Complementar e (d) Eletrônica.

\section{Bibliografia Básica}

Esta categoria relaciona os livros e periódicos que oferecem o suporte teórico e filosófico para os conceitos adotados e desenvolvidos ao longo do texto. Nela, enquadramos os autores e obras de viés mais abrangente para situar nossas reflexões, principalmente as do capítulo introdutório.

ARAÚJO, Ulisses F. A Construção de Escolas Democráticas: Histórias sobre Complexidade, Mudanças e Resistências. São Paulo: Moderna, 2005.

BOURDIEU, Pierre. “O campo científico”. In: Pierre Bourdieu. São Paulo: Ática, 1983.

CANCLINI, Nestor García. Culturas Híbridas. São Paulo: Edusp, 1997.

CASTELLS, Manuel. A Galáxia da Internet: Reflexões sobre a Internet, os Negócios e a Sociedade. Rio de Janeiro: Jorge Zahar Editor, 2003.

. A Era da Informação: Economia Sociedade e Cultura (três volumes).

São Paulo: Paz e Terra, 2002.

CITELLI, Adilson. Comunicação e Educação: a Linguagem em Movimento. São Paulo: Senac, 2000. . Outras linguagens na escola. São Paulo: Cortez, 2000.

DOWBOR, Ladislau. Tecnologias do conhecimento: os desafios da educação. Petrópolis: Vozes, 2001.

DOWNING, John D. H. Mídia Radical: rebeldia nas comunicações e movimentos sociais. São Paulo: SENAC, 2001. 
FERKISS, Victor. O Homem Tecnológico: Mito e Realidade. Rio de Janeiro: Zahar Editores, 1976.

FOUCAULT, Michel. As Palavras e as Coisas: uma Arqueologia das Ciências Humanas. São Paulo: Martins Fontes, 1999.

FREIRE, Paulo. Pedagogia da Autonomia. Rio de Janeiro: Paz e Terra, 2002. . Pedagogia do Oprimido. Rio de Janeiro: Paz e Terra, 1992.

GANDIN, Daniel e GANDIN Luís A. Temas para um Projeto Político-Pedagógico. Petrópolis: Vozes, 2003.

GARDNER, Howard. Estruturas da Mente: A Teoria das Múltiplas Inteligências. Porto Alegre: ArtMed, 1994.

HERNÁNDEZ, Fernando e VENTURA, Montserrat. A organização do currículo por projetos de trabalho. Porto Alegre: Artmed, 1998.

JOHNSON, Steven. Cultura da Interface. Rio de Janeiro: Jorge Zahar, 2001.

KAPLUN, Mario. "Processos educativos e canais de comunicação". In: Comunicação e Educação, jan./abr. 1999, pp. 68-75.

LEÃO, Lucia. O Labirinto da Hipermídia: Arquitetura e Navegação no Ciberespaço. São Paulo: Iluminuras, 2005.

LEVY, Pierre. Cibercultura. São Paulo: Editora 34, 1998a. . A Inteligência Coletiva: por uma antropologia do ciberespaço. São Paulo: Edições Loyola, 1998c. . A Máquina Universo. Porto Alegre: Artmed, 1998d. . As Tecnologias da Inteligência. São Paulo: Editora 34, 1993.

LOPES, Maria Immacolata Vassallo de. O campo da comunicação: reflexões sobre seu estatuto disciplinar. Revista USP (48), São Paulo, dez/2000-fev/2001, pp. 46-57. . "Globalização comunicacional e transformação cultural”. In: MORAES, Denis (org). Por uma outra comunicação. Rio de Janeiro: Record, 2003. MARTÍN-BARBERO, Jesús. Dos meios às mediações. Rio de Janeiro: Ed. UFRJ, 1997. MORAES, Maria C. de. O Paradigma Educacional Emergente. São Paulo: Papirus, 1999. MORIN, Edgar. Os sete saberes necessários à educação do futuro. São Paulo: Cortez, 2000. 
MURRAY, Janet H. Hamlet no Holodeck: o futuro da narrativa no ciberespaço. São Paulo: Unesp/Itaú Cultural, 2003.

NEGROPONTE, Nicholas. Vida Digital. São Paulo: Editora Schwarcz Ltda., 2006.

SILVA FILHO, Genésio Zeferino. Educomunicação e sua metodologia: um estudo a partir de ONGs no Brasil. Tese de Doutorado. São Paulo: ECA/USP, 2004.

SILVEIRA, Sérgio A. da. Software Livre: a luta pela liberdade do conhecimento. São Paulo: Editora Fundação Perseu Abramo, 2004.

SILVEIRA, Sérgio A. e CASSINO, João (orgs.). Software Livre e Inclusão Digital. São Paulo: Conrad/ Editora do Brasil, 2003.

. Sociedade da informação ou da comunicação? São Paulo: Cidade Nova, $1997 b$.

SOUSA, Mauro Wilton de. Novas linguagens. São Paulo: Editora Salesiana, 2001.

TAVARES JR, Renato. Educomunicação e expressão comunicativa: a produção radiofônica de crianças e jovens no projeto educom.rádio. Dissertação de Mestrado, São Paulo: ECA/USP, 2007.

WOLF, Mauro. Teorias da comunicação. Lisboa: Ed. Presença, 1995. 


\section{Bibliografia Específica}

$\mathrm{Na}$ qual constam as obras que são citadas de forma direta ou indireta e com maior freqüência, devido a sua vinculação íntima aos temas tratados no texto, além de textos basais sobre o campo da Educomunicação. Esta categoria concentra, ainda, a maior parte do material que se refere, por diferentes abordagens, às relações entre Comunicação, Educação e Tecnologia, ainda que apareçam designadas por expressões concorrentes ou contraditórias.

AFONSO, Carlos. Professores e computadores: Representações, Atitudes e Comportamentos. Rio Tinto (PT): Edições Asa, 1993.

AGUIAR, Maria Eunice G. de. Signos visuais como mediadores tecnológicos em ambientes educacionais virtuais. Dissertação de Mestrado, São Paulo: ECA/USP, 2000.

ALAVA, Seraphin e cols. Ciberespaço e Formações Abertas: Rumo a Novas Práticas Educacionais? Porto Alegre: Artmed, 2002.

ALVES, Patrícia Horta. O Projeto Educom.rádio como política Pública, tese de doutorado, São Paulo: ECA/USP, 2007.

- Pesquisa aponta a emergência do campo da educomunicação. Disponível em: http://www.usp.br/nce/wcp/arq/textos/12.pdf (Acesso em: 10/11/2006).

- Educomunicação: a experiência do Núcleo de Comunicação e Educação/ECA-USP. Dissertação de Mestrado, São Paulo: ECA/USP, 2002.

AZEVEDO, J. A Educação tecnológica nos anos 90. Porto (PT): Edições ASA, 1991.

BACCEGA, Maria A. Gestão de Processos Comunicacionais. São Paulo: Atlas, 2001.

BAPTISTA, João Manuel P. Dias. A Educação Tecnológica e os novos programas. Porto: Edições ASA, 1993.

BARBA, Cecilia Cervantes. Los estrategas de la comunicación: alternativas metodológicas frente a la persistencia del maniqueísmo. Dissertação de Mestrado, Guadalajara: ITESO (México), 1992. 
BARBOSA, Nanci Rodrigues. Mediação e negociação de sentido: em práticas de educação à distância voltadas à formação profissional. Dissertação de Mestrado, São Paulo: ECA/USP, 2000.

BARRETO, R. G. (org.) et al. Tecnologias educacionais e educação a distância: avaliando políticas e práticas. Rio de Janeiro: Quartet, 2001.

BELLONI, Maria L. Educação a Distância. Campinas: Autores Associados, 2001.

BLANCK, Guillermo. "Vigotsky: o homem e sua causa". In: MOLL, Luis C. (org.). Vigotsky e a educação. Porto Alegre: Artmed, 1996, pp. 31-55.

BORDENAVE, Juan E. Diaz. Além dos Meios e Mensagens: introdução à comunicação como processo, tecnologia, sistema e ciência. Petrópolis: Vozes, 1983.

BORDES, Claudia Funari de Sá. A prática da mediação em processos educomunicativos: o caso do Projeto Educom.Rádio.Dissertação de Mestrado, São Paulo:ECA/USP, 2007.

BORRELLI, Francesco Saverio. Conflitos e Justiça. Revista Impulso, v. 15, jan./abr. 2004, pp. 79-86. Piracicaba: Editora Unimep.

BORTONINI, Armando \& SOUSA, Valdemarina (org). Mediação Tecnológica. Porto Alegre: EDIPUCRS, 2004.

BRAGA, José L. e CALAZANS, Regina. Comunicação \& Educação: questões delicadas na interface. São Paulo: Hacker Editores, 2001.

BRASIL. MEC - Secretaria de Educação a Distância (SEED) - Departamento de Informática na Educação a Distância (DIED). Relatório de atividades 1996/2002. Brasília: DF, 2002.

BUCKINGHAM, David. Media Education. Cambridge (UK): Polity Press, 2003. . Crecer en la era de los medios electrónicos. Madrid (ES): Morata, 2002.

CASTORINA, José A.; FERREIRO, Emilia; LERNER, Delia e KOHL DE OLIVEIRA, Marta. Piaget-Vygotsky: novas contribuições para o debate. São Paulo: Ática, 1997.

COLE, Michael. "Desenvolvimento cognitivo e escolarização formal: a evidência da pesquisa transcultural". In: MOLL, Luis C. (org.) Vigotsky e a educação. Porto Alegre: Artmed, 1996. pp. 85-105.

CONSANI, Marciel A. Avaliação de Softwares na Educação Musical, modalidade: percepção. Dissertação de Mestrado, São Paulo: UNESP, 2003. 
- A Cultura Tecnológica e as mudanças qualitativas em Educação,

Monografia de Especialização em “Tecnologias Interativas Aplicadas à Educação”. São Paulo: PUC, 2000.

CROCHIK, José Leon. O Computador no ensino e a limitação da Consciência. São Paulo: Casa do Psicólogo, 1998.

FADE - Fundação de Apoio ao Desenvolvimento da Universidade Federal de Pernambuco. Relatório Parcial do curso Formação Continuada em Mídias na Educação. Encaminhado ao MEC em agosto de 2007.

GALLIMORE, Ronald \& THARP, Roland. "O pensamento educativo na sociedade: ensino, escolarização e discurso escrito". In: MOLL, Luis C. (org.). Vigotsky e a educação. Porto Alegre: Artmed, 1996, pp. 171-199.

GHILARDI, Maria Inês e BARZOTTO, Valdir H. (orgs.) Nas Telas da Mídia. Campinas: Alínea, 2002.

GRASSESCHI, Maria Cecília Castro. Educação: um processo comunicacional? Tese de Doutorado. São Paulo: ECA/USP, 1993.

GRINSPUN, Miriam P. S. Z. (Org.) Educação tecnológica: desafios e perspectivas. São Paulo: Cortez Editora, 1999.

GUINSLAIN, Georges. Didática e Comunicação. Porto (PT): Edições Asa, 1994.

GUTIERREZ, Francisco e PRIETO, Daniel. A mediação pedagógica: educação à distância alternativa. Campinas: Papirus Editora, 1994.

HERNÁNDEZ, Fernando. Cultura visual, mudança educativa e projeto de trabalho. Porto Alegre: Artmed, 1999.

HUERGO, Jorge. Cultura escolar, Cultura Mediática, Intersecciones. Bogotá (CO): Universidad Pedagógica Nacional, 1999.

ISLAS, Octávio. La era McLuhan: Parteaguas teórico en las Ciencias de la Comunicación. Disponível em: http://www.mexicanadecomunicacion.com.mx (acesso em 10 jul. 2007).

JACQUINOT, Geneviève. O que é um educomunicador? Disponível em: www.educomradio.com.br (Acesso em 19 ago. 2005).

JIMENEZ, Márcia Coutinho Ramos. A Internet na escola pública estadual: um novo âmbito de mediação. Dissertação de Mestrado, São Paulo: ECA/USP, 2002. 
KAPLÚN, Mário. Processos educativos e canais de comunicação. Revista Comunicação \& Educação (14), São Paulo, jan./abr. de 1999, pp. 68-75.

LITWIN, Edith. Educação a Distância. Porto Alegre: Artmed, 2001.

. Tecnologia Educacional: Política, Histórias e Propostas. Porto Alegre:

Artmed, 1997.

MACHADO, Nilson J. "Qualidade na Educação: as armadilhas do óbvio." In: MANTOAN, Maria Teresa Eglér (org.). Pensando e fazendo educação de qualidade. São Paulo: Editora Moderna, 2002, pp. 13-50.

MARTÍN-BARBERO, Jesús. La Educación desde la comunicación. Buenos Aires (AR): Grupo Editorial Norma, 2002.

. MARTÍN-BARBERO, Jesús. "Retos culturales de la educación a la comunicación.” In: Comunicación, Educación y Cultura. Relaciones, aproximaciones y nuevos retos. Bogotá: Cátedra UNESCO de Comunicación Social. Facultad de Comunicación y Lenguaje, Pontificia Universidad Javeriana, 1999.

. Heredando el futuro: pensar la educación desde la comunicación.

Nómadas. Bogotá: Fundación Universidad Central, 1996.

MARTINS, Mirian Celeste. "Mediação: tecendo encontros sensíveis com a arte". In: ARTEunesp. São Paulo, 13: 221-234, 1997.

MENEZES, Sulamita Ponzo de. Logo e a formação de professores: o uso interdisciplinar do computador na educação. Dissertação de Mestrado. São Paulo: ECA/USP, 1993.

MOLL, Luis C. (org.) Vigotsky e a educação. Porto Alegre: Artmed, 1996.

MORAES, Raquel de A. Informática na Educação. Rio de Janeiro: DP\&A, 2000.

MOREIRA, Vasco. Escola do futuro: sedução ou inquietação? As novas tecnologias e o reencantamento da escola. Porto (PT): Porto Editora, 2001.

OLIVEIRA, Maria Rita N. S. "Do mito da tecnologia ao paradigma tecnológico: a mediação pedagógica nas práticas didático-pedagógicas”. Revista Brasileira de Educação, v. 18 (set./out./nov./dez.), pp. 101-107, 2001.

OLIVEIRA, Tânia Amaral. Uso da TV e do vídeo no espaço escolar: uma experiência de educomunicação. Dissertação de Mestrado. São Paulo: ECA/USP, 2004.

OLIVEIRA, Vera B. (org.). Informática em Psicopedagogia. São Paulo: SENAC, 1996. 
OROZCO, Guillermo. "Elementos para uma política de educación mediática". In:

VALDERRAMA, Carlos. Comunicación-Educación, Coordinadas, abordajes y travesías. Bogotá: Universidad Central/DIUC, 2000, p.125.

- "Professores e meios de comunicação: desafios, estereótipos".In:

Revista Comunicação \& Educação (10), São Paulo, set./dez. 1997, pp. 57-68.

PALLOFF, Rena \& PRAT, Keith. Construindo comunidades de aprendizagem no ciberespaço. Porto Alegre: Artmed, 2002.

. O Aluno Virtual: um guia para trabalhar com estudantes on-line. Porto

Alegre: Artmed, 2004.

PAPPERT, Seymour. A máquina das crianças. Porto Alegre: ArtMed, 1994.

PASSARELLI, Brasilina. Interfaces Digitais na Educação: @lucinações Consentidas. Tese de Livre Docência, São Paulo: ECA-USP, 2003.

RAMAL, A. C. Educação na cibercultura: hipertextualidade, leitura, escrita e aprendizagem. Porto Alegre: Artmed, 2002.

RANGEL, Mary et al. "Novas tecnologias aplicadas à educação: reflexões pragmáticas". In: Linhas críticas - Revista Semestral da Faculdade de Educação da UnB, Brasília, 6: 45-53, jan. 2000.

REIS, Maria de Fátima. Educação Tecnológica: A Montanha Pariu um Rato? Porto (PT): Porto Editora, 1999.

RIPPER, Afira Von. “O preparo do professor para as novas tecnologias”. In: OLIVEIRA, Vera B. de(org.). Informática em psicopedagogia. São Paulo: Senac, 1996, pp.57-83.

ROSSETI, Fernando. Mídia e Escola: perspectivas para políticas públicas. São Paulo: Unicef-Brasil, 2005. . "Projetos de Educação, Comunicação \& Participação: Perspectivas para Políticas Públicas”. Disponível em: http://rossetti.sites.uol.com.br (acesso em 22/09/07).

SAMPAIO, Marisa N. e LEITE, Lígia S. Alfabetização Tecnológica do Professor. Petrópolis: Vozes, 2000.

SANCHO, Juana M. e HERNÁNEZ, Fernando e cols. Tecnologias para transformar a Educação. Porto Alegre: Artmed, 2006. 
SANTOS, Isabel Pereira dos. O software de simulação e o sistema cognitivo humano: as bases epistemológicas na interface comunicação e educação. Dissertação de Mestrado, São Paulo: ECA/USP, 2004.

SARTORI, Ademilde S. Gestão da comunicação na educação superior à distância. Tese de Doutorado. São Paulo: ECA/USP, 2005.

SARTORI, Ademilde S. e PRADO SOARES, Maria Salete. "Concepção dialógica e as NTIC: a Educomunicação e os Ecossistemas Comunicativos". Disponível em: http://www.paulofreire.org.br/ (Acesso em 12 dez. 2007).

SCHLÜNZEN Jr., Klaus. Aprendizagem, cultura e tecnologia: desenvolvendo potencialidades corporativas. São Paulo: Editora UNESP, 2003.

SETZER, Valdemar W. Meios eletrônicos e educação: uma visão alternativa. São Paulo: Escrituras, 2001.

SIGNATES, Luiz. "Estudos sobre o conceito de mediação". In: Revista Novos Olhares. ECA-USP, ano 01, nº 2, 1998, pp. 37-49.

SILVA, Angela C. da. Infovias para Educação. Campinas: Alínea, 2004.

SILVA, Marcos (org.). Educação Online. São Paulo: Edições Loyola, 2003. . Sala de Aula Interativa. Rio de Janeiro: Quartet, 2000.

SOARES, Ismar de Oliveira. "Alfabetização e Educomunicação: O papel dos meios de comunicação e informação na educação de jovens e adultos ao longo da vida." Disponível em: www.informacao.srv.br/telecongresso/lib/biblioteca/uploads/346.doc (Acesso em 11/12/2005).

. "Caminhos da Educomunicação na América Latina e nos Estados Unidos”. In: Agenda do educom.rádio, nº 1, São Paulo, 9 a 16 set. 2003.

. "Metodologias da educação para comunicação e gestão comunicativa no Brasil e na América Latina". In: BACCEGA, Maria Aparecida. Gestão de processos comunicacionais. São Paulo: Atlas, 2002. . (org.). Caminhos da Educomunicação. São Paulo: Salesianas, 2001. . "Educomunicação: as perspectivas do reconhecimento de um novo campo de intervenção social: o caso dos Estados Unidos". In: Eccos Revista Científica Uninove. v.2, nº 2, dez 2000a. 
. "Educomunicação: um campo de mediações". In: Comunicação \& Educação. v. 19, pp.12-24, set./dez. 2000b.

(coord.). A Inter-relação Comunicação e Educação no Âmbito da

Cultura Latino-americana (O Perfil dos Pesquisadores e Especialistas na Área). Relatório Final de Pesquisa Temática - FAPESP Processo No 96/07259-2, São Paulo, 1999a.

. "Comunicação/Educação: a emergência de um novo campo e o perfil de seus profissionais". In: Contato: revista brasileira de comunicação, arte e educação, ano 1, nº 2, pp. 5-75, Brasília, jan./mar. 1999b.

. "A Era da Informação". Anais do XXV SBTE. Revista Tecnologia Educacional. v. 22, jul./out. 1999c.

. Lei de Diretrizes e Bases e a Comunicação no sistema de ensino.

Revista Comunicação \& Educação (8). São Paulo, 1997, pp.23-26. . Para uma leitura crítica dos jornais. São Paulo: Paulinas, 1984.

SOUSA, Mauro Wilton. Comunicação e Educação: entre meios e mediações (Cadernos de Pesquisa n ${ }^{\circ}$ 106). São Paulo: Fundação Carlos Chagas/ Ed. Autores Associados, 1999.

TAJRA, Sanmya F. Comunidades Virtuais: um Fenômeno na Sociedade do Conhecimento. São Paulo: Editora Érica, 2005.

THOMPSON, John B. A mídia e a modernidade. Petrópolis: Vozes, 1998.

VALENTE, José A. Por que o Computador na educação. Campinas: NIED-Unicamp, 1995a. Disponível em: http://nied.unicamp.br. (Acesso em 5 mai. 2004).

- Diferentes usos do computador na educação. Campinas: NIEDUnicamp, 1995b. Disponível em http://nied.unicamp.br. (Acesso em 10 mai. 2004)

VIGOTSKI, L. S. Pensamento e Linguagem. São Paulo: Martins Fontes, 1999.

. A formação social da mente. São Paulo: Martins Fontes, 1999.

VIANA, Claudemir Edson. O processo educomunicacional: a mídia na escola. Dissertação de Mestrado. São Paulo: ECA/USP, 2000.

WERTSCH, James V. "A voz da racionalidade em uma abordagem sociocultural da mente”. In: MOLL, Luis C. (org.). Vigotsky e a educação. Porto Alegre: Artmed, 1996, pp. 107-121. 


\section{Bibliografia complementar}

Composta pelo conjunto de guias de referência, manuais de pesquisa, documentos oficiais e demais obras a que recorremos sempre que é necessário para ilustrar uma afirmação ou referenciar um contexto determinado de análise.

ADORNO, Theodor W. Filosofia da nova música. São Paulo: Perspectiva, 2007. . Indústria cultural e sociedade. São Paulo: Paz e Terra, 2007.

ALMEIDA, Maria Elizabeth de. PROINFO: Informática e Formação de Professores. v. 1. Brasília: MEC/SEED, 2000.

AUSUBEL, D. P. Aquisição e retenção de conhecimentos: uma perspectiva cognitiva. Lisboa: Plátano, 2003.

BARBERA. Dizionario Etimologico Italiano. Firenze (IT): G. Barbera Editore, 1952.

BOGDAN, Romero C. e BIKLEN, Sari K. Investigação Qualitativa em Educação. Porto: Porto Editora, 1999.

BORDENAVE, Juan Díaz e PEREIRA, Adair M. Estratégias de ensino-aprendizagem. Rio de Janeiro: Vozes, 1991.

BOUTINET, Jean-Pierre. Antropologia do projeto. Porto Alegre: Artmed, 2002.

BRANDÃO, Carlos Rodrigues (org.). Pesquisa participante. São Paulo: Brasiliense, 1999.

BRASIL. Nova LDB-Lei no 9.394, de 20 de dezembro de 1996. Brasília: Poder Executivo, 1997.

. Parâmetros Curriculares Nacionais - Artes. Brasília: Ministério da Educação e do Desporto, 1997.

CAMBI, Franco. História da Pedagogia. São Paulo: Editora Unesp, 1999.

COLlin S. M. H. Dicionário de Informática, de Multimídia e Realidade Virtual. São Paulo: Melhoramentos, 2001.

DALMÁS, Angelo. Planejamento participativo na Escola: elaboração, acompanhamento e avaliação. Petrópolis, Vozes, 2005.

D’AMBROSIO, Ubiratan. Transdisciplinaridade. São Paulo: Palas Athena, 2001.

DEMO, Pedro. Metodologia Científica em Ciências Sociais. São Paulo: Atlas, 1989. 
ECO, Umberto. Como se Faz uma Tese. São Paulo: Perspectiva, 2005. . A estrutura ausente. São Paulo: Perspectiva, 1974.

ENZENSBERGER, Hans M. Elementos para uma Teoria dos Meios de Comunicação. Rio de Janeiro: Edições Tempo Brasileiro, 1976.

FICHEMAN, Irene Karaguilla. Aprendizagem colaborativa a distância apoiada por meios eletrônicos interativos. Dissertação de Mestrado. São Paulo: POLI-USP, 2002.

FONSECA Jr., Fernando Moraes e ALMEIDA, Fernando José de. PROINFO: Projetos e Ambientes Inovadores. Brasília: MEC/SEED, 2000.

GOSCIOLA, Vicente. Roteiro para as Novas Mídias: do Game à TV Interativa. São Paulo: SENAC, 2003.

GROVE. Dicionário Grove de Música: edição concisa. Rio de Janeiro: Jorge Zahar, 1994.

IAZZETTA, Fernando Henrique de O. Música e Mediação Tecnológica. Tese de livredocência, São Paulo: ECA-USP, 2006.

IPFLING, Heinz-Jurgen. Vocabulário Fundamental de Pedagogia. Lisboa: Edições 70, 1974.

KRÜGER, Susana E. Desenvolvimento, testagem e proposta de um roteiro para avaliação de software para educação musical. Porto Alegre, 2000. Dissertação de Mestrado, Instituto de Artes da UFRGS.

LAUFER, Roger. Introdução à Textologia. São Paulo: Perspectiva, 1980.

LEVY, Pierre. A ideografia dinâmica: rumo a uma imaginação artificial? São Paulo: Edições Loyola, 1998b.

LOPES, Maria Immacolata V. de. Pesquisa em Comunicação. São Paulo: Loyola, 2003. . "O campo da comunicação: reflexões sobre seu estatuto disciplinar". In: Revista USP (48), São Paulo, dez./2000-fev./2001, pp. 46-57.

LÜDKE, Menga e ANDRÉ, Marli E. D. A. Pesquisa em Educação: abordagens qualitativas. São Paulo: EPU, 1988.

LURIA, Alexander R. "Vigotskii". In: VIGOTISKII, Lev S.; LURIA, Alexander R.; LEONTIEV, Alexis N. Linguagem, desenvolvimento e aprendizagem. São Paulo: Ícone, 2001. 
MAIO, Ana Zeferina Ferreira. Um modelo de núcleo virtual de aprendizagem sobre percepção visual aplicado às imagens de video: análise e criação. Tese de doutorado. Florianópolis: Programa de PG em Engenharia de Produção/UFSC, 2005.

MARCONI, Marina de A. e LAKATOS, Eva M. Metodologia do Trabalho Científico. São Paulo: Atlas, 2001.

MARQUES DE MELO, J. \& SATTLER, L. (Orgs.) Direitos à Comunicação na Sociedade da Informação. São Bernardo do Campo: UMESP, 2005. . História do pensamento comunicacional. São Paulo: Paulus, 2003.

MATTELART, Armand e Michèle. História das teorias da comunicação. São Paulo: Edições Loyola, 1999.

McNAMEE, Gillian Dowley. "Aprendendo a ler e a escrever na área central da cidade: um estudo longitudinal de mudança na comunidade". In: MOLL, Luis C. (org.). Vigotsky e a educação. Porto Alegre: Artmed, 1996, pp. 279-295.

McLUHAN, Marshall. Os meios de comunicação como extensões do homem. São Paulo: Cultrix, 1979.

MOREIRA, Marco Antonio. Mapas conceituais e aprendizagem significativa. Disponível em: http://www.if.ufrgs.br/ moreira/mapasport.pdf (Acesso em 19 ago. 2006).

NOVAK, Joseph D. e GOWIN, D. B. Aprender a aprender. Lisboa: Plátano Edições Técnicas, 1996.

PEARSON, Ian (editor). The Atlas of the Future. London (UK): Myriad Editions, 1998.

PEREIRA, Júlio Cesar R. Análise de Dados Qualitativos. São Paulo: Edusp, 2001.

RAMOS, Daniela O. Astrologia on-line: um estudo de mediação tecnológica. Dissertação de Mestrado, São Paulo: ECA-USP, 2002.

SANTOS F $F^{o}$, José Camilo dos e GAMBOA, Silvio Sánchez. Pesquisa Educacional: quantidade-qualidade. São Paulo: Cortez, 2000.

SÃO PAULO. Portaria $n^{\circ} 5.147$ de 17/10/1997. São Paulo: Secretaria Municipal de Educação, 1997.

SAYEG, Elisa. Psicologia e Informática: Interfaces e Desafios. São Paulo: CRP-SP/ Casa do Psicólogo, 2000.

TAPIA, Jorge Rubem Biton. A trajetória da política de informática brasileira. Campinas: Papirus, 1995. 
TENÓRIO, Robinson Moreira. Cérebros e Computadores - A complementaridade analógico-digital na informática e na educação. São Paulo: Escrituras, 1998.

. Computadores de Papel: máquinas abstratas para um ensino concreto.

São Paulo: Editora Cortez, 1991.

THIOLLENT, Michel. Metodologia de Pesquisa-Ação. São Paulo: Cortez, 2000.

TRIVIÑOS, Augusto N. S. Introdução à pesquisa em Ciências Sociais: A Pesquisa Qualitativa em Educação. São Paulo: Atlas, 1987.

TUDGE, Jonathan. "Vygotsky, a zona de desenvolvimento proximal e a colaboração entre pares: implicações para a prática em sala de aula". In: MOLL, Luis C. (org.). Vigotsky e a educação. Porto Alegre: Artmed, 1996, pp. 152-168.

UNESCO. O Educador e a Abordagem Sistêmica. Lisboa (PT): Editorial Estampa, 1989.

VERDELHO, Telmo. "Terminologias na língua portuguesa: perspectiva diacrônica". In: La història dels llenguatges iberoromànics d'especialitat (Segles XVII-XIX): solucions per al present, ed. de Jenny Brumme, Barcelona, Instituti Universitari di Lingüística Aplicada, Universitat Pompeu Fabra, 1998, pp. 98-131. Disponível em: http://clp.dlc.ua.pt/Publicacoes.aspx (Acesso em 12 set. 2007).

VIGOTISKII, Lev S.; LURIA, Alexander R.; LEONTIEV, Alexis N. Linguagem, desenvolvimento e aprendizagem. São Paulo: Ícone, 2001.

WITTROCK, M. C. (org.). La investigación de la enseñanza. Barcelona: Ediciones Paidos, 1989. 


\section{Bibliografia Eletrônica}

Este item, que encerra o capítulo de referências bibliográficas, consiste num repositório de links relativos aos sites consultados durante a elaboração da tese e que, até a entrega dos originais, permanecem ativos para consulta on-line.

\section{Vídeo}

MORENO, Márcia e DEL ROSSO, Marco Aurélio. O FUTURO da escola e o impacto dos novos meios de comunicação no modelo de escola atual. São Paulo, TV PUC de São Paulo, nov. 1995. Vídeo em formato digital, disponível em http://www.paulofreire.ufpb.br/paulofreire/Controle?op=detalhe\&tipo=Video\&id=37 e capturado em dezembro de 2007.

\section{Sites}

http://www.abed.org.br/

http://www.abtu.org.br/default_home.asp

http://acessolivre.capes.gov.br/

http://www.agenciaugauga.org.br/index.php

http://www.airecomun.com/educo.htm

http://www.andi.org.br/

http://arruda.rits.org.br/notitia1/servlet/newstorm.notitia.apresentacao.ServletDeSecao

http://www.bibvirt.futuro.usp.br/index.php

http://bocc.ubi.pt/

http://www.cenpec.org.br/modules/home/

http://www.cg.org.br/infoteca/documentacao/index.htm

http://bve.cibec.inep.gov.br/ac_rap.asp?cat=31\&nome=Tecnologia\%20e\%20Educação

http://www.cibersociedad.net/

http://www.coletivodigital.org.br/

http://www.comunica.org/

http://www.consciencia.net/

http:/contexto-educativo.com.ar/

http://www.educatica.net/ 
www.educomradio.com.br

http://www.eproinfo.mec.gov.br/

http://etd.lsu.edu/cgi-bin/ETD-browse/browse

http://www.icoletiva.com.br/icoletiva/

http://www.ideiasocial.org.br/

http://www.if.ufrgs.br/

http://ccdoc.iteso.mx/

http://www.iti.br/

http://www.koob.ru/vigodsky_v_1/vihotskij_mishlenie_i_rech

http://www.mct.gov.br/

http://moodle.fe.up.pt/

http://www.museudocomputador.com.br/contatos.php

http://nied.unicamp.br

http://www.paulofreire.org.br/asp/Index.asp

http://www.piratininga.org.br/

http://pedagogia.incubadora.fapesp.br/portal/

http://www.pedagogico.com.br/

http://portal.mec.gov.br/

http://portal.mec.gov.br/seed/

http://www.psicopedagogia.com.br/

http://www.pucsp.br/pos/ped/resumo/

http://www.radiobras.gov.br

http://www.responsabilidadesocial.org.br/

http://scholar.google.com.br/

http://uab.mec.gov.br/

http://www.universiabrasil.net/

http://brazil.usaid.gov/subarea.php?id $=61$

http://www.usp.br/nce/aeducomunicacao/saibamais/textos/ 


\section{CRÉDITOS DO AUTOR}

Marciel Consani é músico de formação. Como educador, atua há mais de vinte anos nos mais diversos contextos, tais como educação superior, formação docente, ensino fundamental, educação infantil e oficinas livres de cultura e arte para público variado, além de registrar atuação junto a projetos sociais na função de Arte-Educador.

Sem nunca abandonar de todo a carreira musical, titulou-se como especialista em Tecnologias Interativas Aplicadas à Educação pela PUC de São Paulo em 2000, com a entrega da Monografia A Cultura Tecnológica e as mudanças qualitativas em Educação, orientada pela Profa. Dra. Sulamita Ponzo de Menezes.

Obteve, quatro anos depois, o título de Mestre em Educação Musical pelo Instituto de Artes da Universidade Estadual Paulista (Unesp) com a dissertação intitulada Avaliação de Softwares na Educação Musical: Modalidade Percepção, sob a orientação da Profa. Dra. Maria de Lourdes Sekeff.

$\mathrm{Na}$ mesma época, atuou como webwriter colaborador da Editora Moderna, produzindo conteúdo online dirigido a professores de todas as áreas.

Além de dedicar-se à carreira acadêmica, estudando a Mediação Tecnológica e a Educomunicação, tem prestado, ao longo dos últimos anos, serviços variados — produção de material educativo, mediação pedagógica, coordenação de atividades pedagógicas — às seguintes instituições:

- Governo Federal: Ministério da Educação e Cultura, Ministério do Trabalho, Ministério do Turismo;

- Governo Estadual (SP): Secretaria de Estado da Cultura de São Paulo, Secretaria Estadual do Bem-Estar Social, Secretaria do Menor (SP);

- Governo Municipal (São Paulo): Secretaria Municipal da Educação de São Paulo, Secretaria Municipal da Cultura de São Paulo;

- Outras: SENAC-SP.

Atualmente, é professor dos cursos de Comunicação Social das Faculdades Integradas do Rio Branco e Faculdade das Américas, ambas na capital paulista.

É autor do livro Como usar o Rádio na Sala de Aula, publicado pela Editora Contexto em 2007. 
ANEXOS 


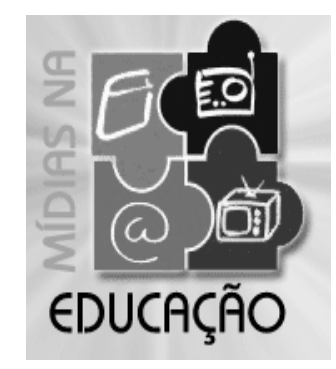

\section{Guia Didático do Tutor}

\section{Apresentação}

Prezado Tutor,

Neste guia didático estão incluídas todas as orientações necessárias para a boa prática de tutoria do módulo Mídia Impressa.

Bom Trabalho!

\section{Objetivos}

Alguns objetivos específicos do trabalho de tutoria são:

$\checkmark$ Incentivar o aluno no desenvolvimento das atividades previstas em cada etapa do módulo.

$\checkmark$ Aperfeiçoar a competência comunicativa dos alunos.

$\checkmark$ Capacitar o aluno a produzir diferentes tipos de textos como base para diferentes mídias.

$\checkmark$ Proporcionar a realização de atividades que utilizem apresentações multimídias, spots para rádio, pequenos vídeos, criação de sites (blogs, fotologs) de entrevistas, de exposições de temas e pesquisas, realizadas através de situações problema, que oportunizem ao aluno o desenvolvimento de um produto que possa ser utilizado como recurso didático em sala de aula.

$\checkmark$ Dominar os conteúdos previstos para cada etapa, bem como, todas as atividades planejadas.

\section{Metodologia}

Os módulos que compõem o curso serão disponibilizados no E-Proinfo, ambiente virtual disponível no site do MEC. Os participantes terão acesso a este ambiente, mediante matrícula na disciplina, autorizada pela Secretaria de Educação, uma senha gerada pelo sistema e um login criado pelo próprio aluno, no ato da inscrição.

Cada módulo deverá apresentar explicitamente, em local apropriado, a introdução, objetivos, ferramentas de interação síncrona e assíncrona, exercícios e tarefas, trabalhos em grupos e individuais, pesquisas e a forma como serão feitas as avaliações de cada módulo. 
Todas as atividades propostas aos alunos terão data limite para entrega, explicitadas no momento da solicitação das tarefas, assim como as respostas e comentários do tutor.

O ambiente oferecerá ao aluno opções de interatividade que o auxiliarão a fazer uma auto-avaliação da aprendizagem.

As atividades serão trabalhadas nas várias ferramentas do E-Proinfo: Fórum, Mural, Portfolio, Chat e Correio.

Nestes espaços o professor procurará esclarecer as dúvidas do aluno.

O tutor deverá promover a interação dos alunos, manter o grupo coeso e interessado e zelar para que o ambiente virtual torne-se um ambiente de aprendizagem colaborativa e participativa. A participação do tutor, no curso, será diária.

Serão agendadas pelo tutor e/ou pelo professor sessões de interação síncrona (batepapo) dentro da sala virtual. Os horários das sessões serão acordados entre os participantes.

\section{Avaliação}

O conceito A $(9,0$ a 10,0$)$ corresponde ao aproveitamento total, pelo aluno, dos objetivos propostos; o conceito B $(8,0$ a 9,0$)$ e C $(7,0$ a 8,0$)$ correspondem ao aproveitamento suficiente dos objetivos e o conceito $\mathrm{R}$ (menor que 7,0 ) corresponde ao aproveitamento insuficiente, pelo aluno, dos objetivos propostos pelo componente curricular.

A menção final é o juízo que o tutor fará do aproveitamento do aluno, considerando os seguintes instrumentos de avaliação:

- Trabalhos individuais (produção de textos e reflexões);

- Trabalhos em grupo (pesquisas e seminários);

- Participação nas discussões e sessões de interação síncrona e assíncrona propostas.

Os trabalhos de pesquisa individuais e em grupo serão acompanhados pelo tutor e ao final, poderão ser enviados para a sala virtual para discussões e comentários de todos os participantes do curso.

As participações nas discussões desenvolvidas nos diversos ambientes do curso são registradas e quantificadas pelo programa E-Proinfo. O tutor poderá considerá-las não apenas quantitativamente, mas também pela qualidade das interações, das idéias e opiniões do aluno. Esses dados auxiliarão o tutor na composição do perfil do aprendiz e composição do conceito final.

O E-Proinfo guarda registro de todas as participações de tutores e alunos, em todas as sessões. Esses registros servem como parâmetro para o acompanhamento da participação dos alunos e de seu processo de aprendizagem 


\section{Programação das Atividades do Módulo}

\section{$1^{\text {a }}$ Etapa}

Na primeira etapa serão desenvolvidas atividades que demonstrem a importância de uma tipologia de texto para o aprimoramento da competência comunicativa dos alunos.

É desejável que o aluno realize as tarefas desta etapa na ordem sugerida que aparece neste guia.

Procurando objetivar os estudos dos alunos foi criado um número seqüencial para cada uma das atividades do módulo. Na primeira etapa do módulo as atividades a serem desenvolvidas são:

\section{1) Textos Epistolares}

- Ouça com seus alunos o programa da Rádio Escola da SEED/MEC: http://portal.mec.gov.br/seed/index.php?option=content\&task=view\&id=155\&ltemid=292 Clic na Série do Professor e depois no programa Ler e escrever com muito prazer, a diversidade textual na alfabetização;

\section{Escolha o Programa 1: Cartas bilhetes e ofícios}

"Neste programa, saiba como introduzir a leitura e a escrita de cartas, ofícios e bilhetes. (...) Entenda a necessidade de um motivo real para produzir esses textos em sala de aula. Observe melhor seus usos, funções e estruturas. Conheça também as atividades que podem ser desenvolvidas com seus alunos". (http://200.130.6.200/ - acesso em 15/05/2006).

Para tanto, clique no link sugestões de atividades. Fazer link http://200.130.6.200/ Converse com seus alunos sobre o que ouviram e produza com eles um texto falando sobre o tema.

Após realizar esta atividade em sala de aula com seus alunos, discuta sobre sua prática com seus colegas de curso no Fórum do E-Proinfo.

\section{Como Fazer}

A atividade de produção de textos deverá ser desenvolvida utilizando um editor de textos para redigir o texto solicitado e fazer uma apresentação em power point, disponibilizandoas na plataforma de ensino a distância, utilizando a ferramenta webfólio.

Ferramentas: Biblioteca, Webfólio e Fórum para interação entre os colegas e discussão do tema abordado.

Ler os comentários realizados pelo professor na ferramenta Webfólio;

Participar do Fórum para comentar a atividade realizada e revisar os conteúdos estudados 


\section{2) Textos Publicitários e Textos Humorísticos}

- Após o estudo e pesquisa sobre os suportes apresentados, você, professor, deverá elaborar um texto publicitário e publicá-lo em seu webfólio.

- Existem diversos softwares que permitem desenvolver a construção de conhecimentos. Estamos propondo que você conheça um software que pode ser utilizado por diversas idades e com um grande número de possibilidades. O Programa que estamos indicando é para a construção de Histórias em Quadrinhos e você poderá encontrá-lo no seguinte endereço: http://www.monica.com.br/software/quadrinh.htm

- Faça o download do software e instale-o em sua escola. Seu uso é fácil, pois ele é muito intuitivo. Explore-o e solte sua imaginação!

- Não deixe de participar do chat para uma maior interação entre você, seus colegas e seu tutor

Vídeos da TV Escola; computador, software, Internet e plataforma e-proinfo.

\section{3) Textos de Informação Científica}

- Após o estudo e pesquisa sobre os diferentes tipos de textos de informação científica apresentados, você, professor, deverá fazer uma pesquisa com seus alunos sobre algum personagem importante na história e cultura de seu município ou de sua escola.

- Escreva, juntamente com seus alunos, a biografia desse personagem e publique-a em seu webfólio. Esta atividade deverá ser discutida no Fórum.

- Também deverá ser feito um chat para uma maior interação entre você, seus colegas e seu tutor.

\section{4) Textos Instrucionais}

- Após o estudo e pesquisa sobre os diferentes tipos de textos de instrucionais, você, professor, deverá escolher com seus alunos uma receita culinária (pesquise sobre os pratos típicos da região), criar o passo a passo da receita, ilustrá-la com fotos ou desenhos utilizando um editor de textos e de imagens e publicá-la em seu webfólio. (você também poderá fazer esse prato na cozinha da escola com seus alunos)

- Esta atividade deverá ser comentada no Fórum.

- Não se esqueça de participar do chat com seus colegas e com seu tutor

\section{5) Textos Jornalísticos}

Após o estudo e pesquisa sobre os textos jornalísticos apresentados, você, professor, deverá escolher uma destas modalidades e elaborar um texto que deverá ser publicado em seu webfólio e discutido no Fórum. Também deverá ser feito um chat para uma maior interação entre você, seus colegas e seu tutor. 


\section{$2^{\mathrm{a}}$ Etapa}

$\mathrm{Na}$ segunda etapa serão desenvolvidas atividades que proporcionem ao aluno a fundamentação teórica e motivacional relacionada a conceitos de texto, suporte e formato a partir dos quais o aluno identificará as características dos textos produzidos para cada suporte especifico.

É desejável que o aluno realize as tarefas desta etapa na ordem sugerida que aparece neste guia.

Procurando objetivar os estudos dos alunos foi criado um número seqüencial para cada uma das atividades do módulo. Na segunda etapa do módulo as atividades a serem desenvolvidas são:

1) A atividade consiste em reescrever um texto originalmente produzido para o suporte impresso. O aluno deverá eleger uma mídia (rádio, TV ou página da internet) e desenvolver um texto com as características adequadas à mídia escolhida. Para isso será necessário seguir as orientações apresentadas, para que o texto, com as mesmas informações, seja lido no rádio, apresentado na televisão ou disponibilizado na Web.

\section{O aluno deve:}

- Ler o enunciado da atividade;

- Produzir o texto solicitado em um editor de textos;

- Disponibilizar o texto na ferramenta Diário de Bordo;

- Ler os comentários realizados pelo professor;

- Participar do chat para comentar a atividade realizada e revisar os conteúdos estudados.

\section{O professor (Tutor)}

- Esclarecer dúvidas sobre a atividade desta aula.

- Analisar/avaliar o texto produzido;

- Fazer comentários sobre os trabalhos na ferramenta "webfólio";

- Comentar a atividade realizada no Fórum a ser criado para esta aula e revisar os conteúdos estudados.

- Realizar um CHAT

Tecnologia utilizada: computador, gravador, editor de imagens, web câmera e sons digitalizados do Programa TV Escola e Rádio Escola.

2) A atividade será desenvolvida em grupos ou em duplas utilizando a ferramenta Equitext (http://ead.si.ufsm.br/equitext) para redigir o texto solicitado, disponibilizando-o na plataforma de ensino a distância e utilizando as ferramentas indicadas.

Ferramenta: Equitext. (Estará disponível na Biblioteca o tutorial para uso da Ferramenta Equitext). 
$3^{\text {a Etapa }}$

$\mathrm{Na}$ terceira etapa serão desenvolvidas atividades que proporcionem ao aluno a fundamentação teórica e motivacional relacionada a conceitos de texto, suporte e formato a partir dos quais o aluno identificará as características dos textos produzidos para cada suporte especifico.

É desejável que o aluno realize as tarefas desta etapa na ordem sugerida que aparece neste guia.

Procurando objetivar os estudos dos alunos foi criado um número seqüencial para cada uma das atividades do módulo. Na segunda etapa do módulo as atividades a serem desenvolvidas são:

\section{1) Determinar a equipe do informativo}

Depois da explicação de como funciona a equipe de um jornal, é hora de você e seus colegas determinarem as funções de cada um na equipe do informativo do grupo. Lembre-se de levar em conta as dicas que foram apresentadas na seqüência do texto para distribuir as atividades. Possivelmente, cada membro do grupo aglutinará mais de uma função. O importante é determinar uma organização equilibrada de tarefas e tomando o cuidado para que todos passem pelo maior número de cargos e atividades possíveis.

\section{CARGO OU FUNÇÃO NOME DO RESPONSÁVEL \\ Pauteiro Nomenomenome \\ Repórter da reportagem Nomenomenome \\ Repórter fotográfico da \\ reportagem \\ Nomenomenome \\ Repórter da entrevista Nomenomenome \\ Repórter da notícia 1 Nomenomenome \\ Repórter da notícia 2 Nomenomenome \\ Revisor Nomenomenome \\ Editor Nomenomenome \\ Diagramador Nomenomenome}

De acordo com as necessidades para a realização do informativo, sua equipe deve ter:

As definições devem ser discutidas no fórum e informadas no portfólio de acordo com o prazo já determinado no cronograma das atividades do semestre. Atenção ao editor, a divulgação da listagem dos nomes e atividades é a primeira tarefa dele. É interessante que após especificadas as funções que cabem aos membros do grupo, cada um releia o trecho que diz respeito a sua atividade. Exemplo, quem será o pauteiro, lembre-se de que é sua responsabilidade determinar 10 sugestões de pautas.

\section{2) Fazer a reunião de pauta}

Conforme foi visto no último texto, a reunião de pauta define os temas que aparecerão no informativo. O grupo deve se organizar e consultar os dias da reunião, cuja discussão acontecerá através do fórum, de acordo com os prazos do cronograma. O procedimento 
para a reunião acontecerá da seguinte maneira: o pauteiro deve colocar as sugestões de pauta no fórum, dando início as discussões e posterior definição dos 5 temas. O editor deve disponibilizar na plataforma o resultado da reunião de pauta, isto é, os temas escolhidos. As informações essenciais são demonstradas no exemplo a seguir:

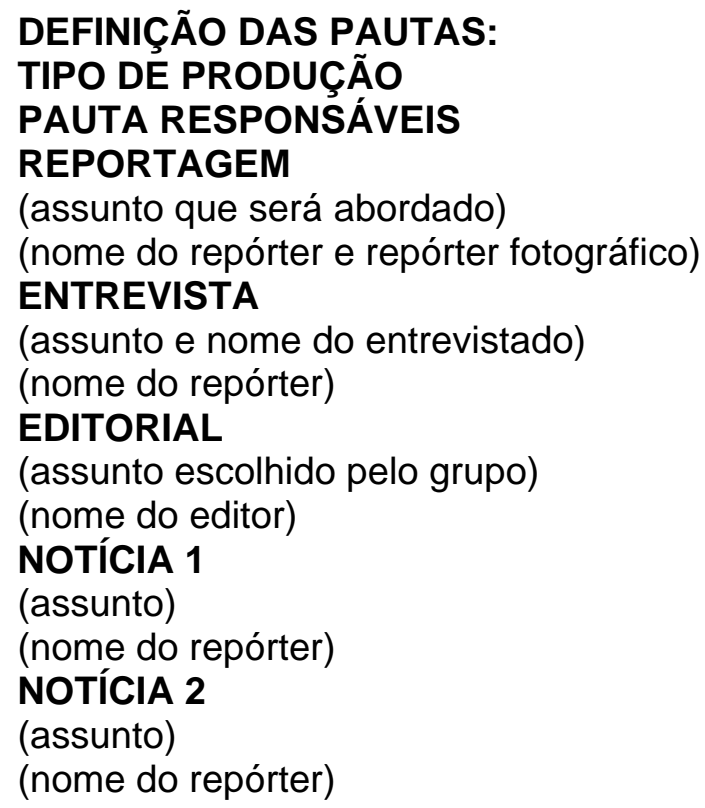

\section{3) Orientações para a finalização do Boletim Informativo}

Os alunos deverão elaborar uma reflexão sobre as aulas, desenvolvendo para isso um script para rádio ou televisão (entre 2 e $5 \mathrm{~min}$ ) ou ainda o organograma de um site (pelo aluno ou grupo de alunos a ser definido) e disponibilizá-la na Biblioteca.

Posteriormente as impressões serão compartilhadas com os colegas, professores e monitores através do chat. Os alunos que se sentirem em condições, podem além do script, implementar suas idéias elaborando a peça radiofônica ou o vídeo.

\section{O aluno deve:}

- Ler o enunciado da atividade;

- Produzir o texto solicitado em um editor de textos;

- Disponibilizar o texto na ferramenta Diário de Bordo;

- Ler os comentários realizados pelo professor;

- Participar do chat para comentar a atividade realizada e revisar os conteúdos estudados.

\section{O professor (Tutor)}

- Esclarecer dúvidas sobre a atividade desta aula.

- Analisar/avaliar o texto produzido;

- Fazer comentários sobre os trabalhos na ferramenta "webfólio";

- Comentar a atividade realizada no Fórum a ser criado para esta aula e revisar os conteúdos estudados.

- Realizar um CHAT 